\title{
Cell turnover and immune cell activation: key factors in the control of plaque progression and phenotype in atherosclerosis?
}

Citation for published version (APA):

Lutgens, E. (2001). Cell turnover and immune cell activation: key factors in the control of plaque progression and phenotype in atherosclerosis? [Doctoral Thesis, Maastricht University]. Datawyse / Universitaire Pers Maastricht. https://doi.org/10.26481/dis.20010215el

Document status and date:

Published: 01/01/2001

DOI:

10.26481/dis.20010215el

Document Version:

Publisher's PDF, also known as Version of record

Please check the document version of this publication:

- A submitted manuscript is the version of the article upon submission and before peer-review. There can be important differences between the submitted version and the official published version of record.

People interested in the research are advised to contact the author for the final version of the publication, or visit the DOI to the publisher's website.

- The final author version and the galley proof are versions of the publication after peer review.

- The final published version features the final layout of the paper including the volume, issue and page numbers.

Link to publication

\footnotetext{
General rights rights.

- You may freely distribute the URL identifying the publication in the public portal. please follow below link for the End User Agreement:

www.umlib.nl/taverne-license

Take down policy

If you believe that this document breaches copyright please contact us at:

repository@maastrichtuniversity.nl

providing details and we will investigate your claim.
}

Copyright and moral rights for the publications made accessible in the public portal are retained by the authors and/or other copyright owners and it is a condition of accessing publications that users recognise and abide by the legal requirements associated with these

- Users may download and print one copy of any publication from the public portal for the purpose of private study or research.

- You may not further distribute the material or use it for any profit-making activity or commercial gain

If the publication is distributed under the terms of Article $25 \mathrm{fa}$ of the Dutch Copyright Act, indicated by the "Taverne" license above, 
Cell Turnover and Immune Cell Activation: Key Factors in the Control of Plaque Progression and Phenotype in Atherosclerosis? 
(C) E. Lutgens, Maastricht 2001 ISBN 90-5278-298-9

Datawyse/ Universitaire Pers Maastricht 
Cell Turnover and Immune Cell Activation: Key Factors in the Control of Plaque Progression and Phenotype in Atherosclerosis?

PROEFSCHRIFT

ter verkrijging van de graad van doctor aan

de Universiteit Maastricht,

op gezag van Rector Magnificus,

Prof. dr. A.C. Nieuwenhulizen Kruseman,

volgens het besluit van het College van Decanen,

in het openbaar te verdedigen

op donderdag 15 februari 2001 om 14.00 uur

door

Esther Lutgens

4 November 1975, geboren te Heerlen.

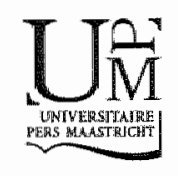




\section{Promotores:}

Prof. dr, M.J.A.P. Daemen

Prot. dr. H.J.J. Wellens

Co-promotor:

Dr. E.D. de Muinck

Beoordelingscommissie:

Prof. dr. H.A.J. Struijker Boudier (voorzitter)

Prof. dr. Th.J.C. van Berkel (Universiteit Leiden)

Prof. dr. J.W. Cohen Tervaert

Prof. dr. M.H. Hotker

Prof. dr. H. Pannekoek (Universiteit van Amsterdam)

Financial support by the Netherlands Heart Foundation, the Stichting RESCAR Maastricht, the Dr. Ir. van de Laar Stichting, and the Dr. Saal van Zwanenbergstichting for the publication of this thesis is gratefully acknowledged. 


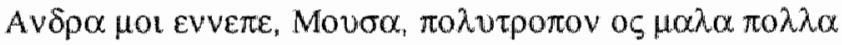

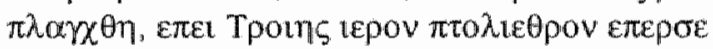

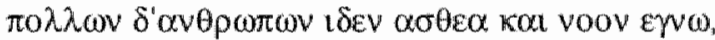

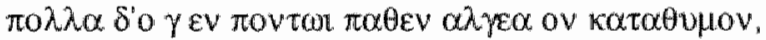

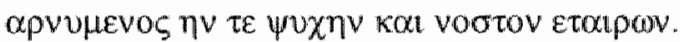

(Homerus, Odyssee, Aanhef). 

Contents

Page

CHAPTER 1

11

General Introduction

CHAPTER 2

Atherosclerosis in ApoE*3Leiden transgenic mice.

From proliferative to atheromatous stage.

CHAPTER 3

Biphasic pattern of cell turnover characterizes the progression from fatty streak to ruptured human atherosclerotic plaques.

CHAPTER 4

Both ApoE -1 - and ApoE*3Leiden mice develop compensatory remodeling and significant carotid artery stenosis.

CHAPTER 5

Gas6-1-/ApoE-1- mice develop a collagen-rich, differently organized plaque phenotype that is prone to intra-plaque hemorrhage.

CHAPTER 6

Requirement for CD154 in the progression of atherosclerosis.

CHAPTER 7

Both early and delayed anti-CD $40 \mathrm{~L}$ antibody treatment induces

a stable plaque phenotype.

CHAPTER 8

General Discussion

Summary

Samenvatting

Dankwoord 


\begin{tabular}{|c|c|}
\hline $\begin{array}{l}\text { AA } \\
\text { ACE } \\
\text { AEC } \\
\text { AHA } \\
\text { All }\end{array}$ & $\begin{array}{l}\text { abdominal aorta } \\
\text { angiotensin converting enzyme } \\
\text { amino-3-9-ethylcarbazole } \\
\text { American Heart Association } \\
\text { angiotensin II }\end{array}$ \\
\hline $\begin{array}{l}\text { ANP } \\
\text { APOE } \\
\text { ASMA } \\
\text { Bak } \\
\text { Bax }\end{array}$ & $\begin{array}{l}\text { atrial natriuretic peptide } \\
\text { apolipoprotein } E \\
\alpha \text {-smooth muscle actin } \\
\text { bcl-2 associated } K \text { protein } \\
\text { bcl-2 associated } X \text { protein }\end{array}$ \\
\hline $\begin{array}{l}\text { BCl-2 } \\
\text { BCT } \\
\text { bFGF } \\
\text { BKLF } \\
\text { BrdU }\end{array}$ & $\begin{array}{l}\text { B-cell leukemia } 2 \\
\text { brachiocephalic trunk } \\
\text { basic fibroblast growth factor } \\
\text { basic Kruppel like factor } \\
5^{\prime} \text {-bromo-2'-deoxyuridine }\end{array}$ \\
\hline $\begin{array}{l}\text { CA } \\
\text { CAK } \\
\text { CCR2 } \\
\text { CdK } \\
\text { CTLA4 }\end{array}$ & $\begin{array}{l}\text { carotid artery } \\
\text { cdk activating kinase } \\
\text { CC-chemokine receptor } 2 \\
\text { cyclin dependent kinase } \\
\text { cytotoxic-T-lymphocyte-associated protein } 4\end{array}$ \\
\hline $\begin{array}{l}\text { DAB } \\
\text { DNA } \\
\text { ECM } \\
\text { EEL } \\
\text { EGE }\end{array}$ & $\begin{array}{l}\text { 3,3'-diaminobenzidine } \\
\text { deoxyribo nucleic acid } \\
\text { extracellular matrix } \\
\text { external elastic lamina } \\
\text { epidermal growth factor }\end{array}$ \\
\hline $\begin{array}{l}\text { EGR-1 } \\
\text { EL } \\
\text { ERK } \\
\text { ES-cells } \\
\text { to }\end{array}$ & $\begin{array}{l}\text { early growth response gene } 1 \\
\text { elastic lamina } \\
\text { extracellular regulated kinase } \\
\text { embryonic stem cells } \\
\text { fibrous cap }\end{array}$ \\
\hline $\begin{array}{l}\text { for } \\
\text { Gas6 } \\
\text { GLA } \\
\text { gm-CSF } \\
\text { GRO- } \alpha\end{array}$ & $\begin{array}{l}\text { foam cell rich } \\
\text { growth arrest specific gene } 6 \\
\text { y-carboxyglutamic acid } \\
\text { granulocyte-macrophage colony stimulating factor } \\
\text { growth related oncogen }\end{array}$ \\
\hline $\begin{array}{l}\text { HE } \\
\text { HUVEC } \\
\text { HFC diet } \\
\text { HSP } \\
\text { ICAM-1 } \\
\text { ICE } \\
\text { IDL }\end{array}$ & $\begin{array}{l}\text { haematoxilin and eosin } \\
\text { human umbilical vein endothelial cells } \\
\text { high-fat/ high-cholesterol diet } \\
\text { heat shock protein } \\
\text { intracellular adhesion molecule } 1 \\
\text { interleukin converting enzyme } \\
\text { intermediate density lipoprotein }\end{array}$ \\
\hline
\end{tabular}




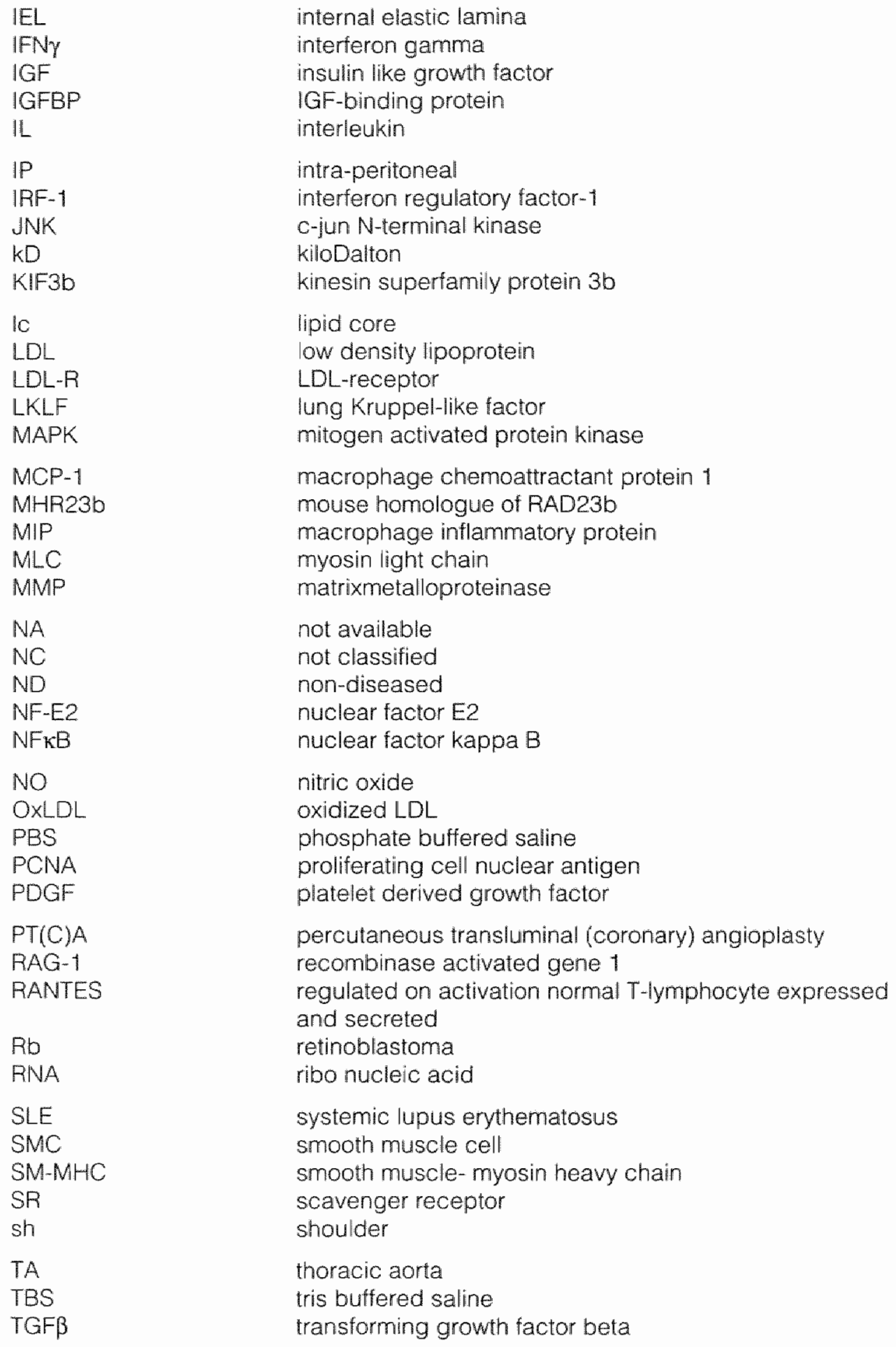


TIMP

TWF

TNF-R

TUNEL

UBF

VCAM

VLDL

VSMC tissue inhibitor of matrixmetalloproteinases

tumor necrosis factor

tumor necrosis factor receptor

terminal deoxyuric nick end labelling

upstream binding factor

vascular cell adhesion molecule

very low density lipoprotein

vascular smooth muscle cell 


\section{Chapter 1}

General Introduction

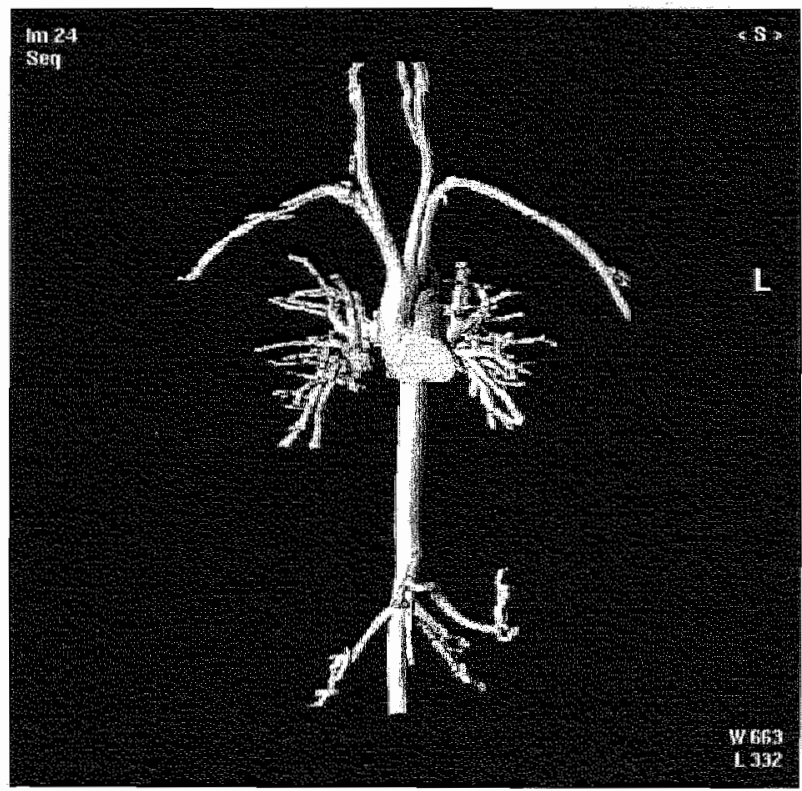




\section{Genera:}
1.
Epidemiology
2. Panogenesils
2.1 Introduction
2.2 Fesporise to injury
2.3 A.HA classification
2.4. Age and stle specific progression
2.5 Remodeling
3. Mouse models of atherosclerosis

\section{This Thasis}
4. Cell turnover
4.1 Iritroduction
42 UIA synthesis
4.2 .1 Cell cycle
4.2.2 Cell cycle regulators
4.3 DUA synthesis and vascular disease
4.3.1 DNA synthesis and arterlial injury

4.3.2 DNA synthesis and animal models of arterial injury

4.3.3 DNA synthesis and human neointima formation

4.3.4 DNA synthesis and prinary aherosclenosis

4.3.5 DWA synthesis and animal models of primary atherosclenosis

4.3.6 DNA synthesis and human atherosclerosis

4.4 Apoplosis

4.5 Apoptosis in vascular disease

4.5.1 Apoptosis and arterial injury

4.5.2 Apoptosis and animal models of arterialinjury

4.5.3 Aproptosis and humar neointima lormation

4.5.4 Apoptosis and primary atherosclerosis

4.5.5 Apoptosis and animal models of primary atherosclerosis

4.5 .6 Apoptosis and human atherosclerosis

5. Atherosclerosis: an inflammatory disease

5.1 Inflammation: general

5.2 Key regulator of inflammation: CD4O-CD4OL system

5.3 Atmerosclerosis and intlammation

5.3. In Inflammatory reactions in atherosclerosis

5.4 The CD40-CD4OL system in atherosclerosis.

5.4 .1 Possible effects of CD4O-CD4OL interactions in atherosclerosis

6. Hypothesis
$7 . \quad$ This thesis


General

1. Epidemiology

Atherosclerosis is the leading cause of morbidity, disability and mortality in the western world. The name, derived from Greek, refers to thickening of the arterial intima (sclerosis 'hardening'), and accumulation of lipid (athere 'gruel"), that characterize the typical atherosclerotic lesion. Atherosclerosis is a systemic disease of the large arteries that affects all persons to a greater or lesser extent, and progresses with age. The atherogenic process silently starts in early childhood ${ }^{1-3}$, and becomes clinically evident in later life, mostly from the fifth/sixth decade 4 .

Depending on the arterial bed affected, and the characteristics of the individual lesions, atherosclerosis leads to distinct clinical manifestations, which may be quite heterogeneous. Atherosclerosis of the coronary arteries may cause angina pectoris and myocardial infarction. Atherosclerosis of the arteries supplying the central nervous system can llead to transient cerebral ischemia and stroke. In the peripheral circulation, atherosclerosis jeopardizes limb viability and may cause intermittent claudication and gangrene. Involvement of the splanchnic circulation can result in mesenteric ischemia and bowel infarction, and involvement of the renal circulation may cause hypertension and renal infarction. The kind of complication, i.e. acute or chronic, is dependent on the composition of the alherosclerotic lesion, and the remodeling response of the artery (see below). Acute complications are usually the result of rupture of an advanced atherosclerotic plaque. This 'rupture' exposes the thrombogenic athere to the blood, which results in thrombus formation and acute acclusion of the vessel. ${ }^{5-7}$ On the other hand, chronic, slowly developing complications are the result of a growing advanced stable plaque that slowly encroaches on the lumen. ${ }^{8}$

Despite our familiarity with the clinical symptoms of the disease, its pathogenesis remains poorly understood. However, it is known that atherosclerosis is a multifactorial disease, and that both genetic and environmental factors, such as different types of hyperlipidemias ${ }^{9}$, hypertension ${ }^{9}$, hyperhomocysteinemia ${ }^{10}$, diabetes $^{11}$, high fat diet ${ }^{12}$, stress, sedentary lifestyle ${ }^{13}$, and smoking ${ }^{9}$, accelerate the progression of atherosclerosis into a clinically symptomatic stage. ${ }^{14-16}$

New pharmacogical intervention with HMG Co-A reductase inhibitors has reduced the incidence of symptomatic atherosclerotic disease by $25 \%-42 \%{ }^{19-21}$ Blood pressure lowering and the cessation of smoking also contribute significantly to a reduction of atherosclerosis related mortality and morbidity. ${ }^{14,17,18,293}$ Other, preventive measures include treatment with ACE-inhibitors ${ }^{19-21}$, the supplementation of anti-oxidants, for example vitamin $\mathrm{E}^{22-24}$ as well as diet and life style changes that need to be initiated early in life to achieve the most effect. ${ }^{13.14}$ Atherosclerosis. nevertheless remains the primary cause of mortality in the industrialized world and is rapidly acquiring the same importance in the developing world. Moreover, the epidemiology of atherosclerosis is changing with an increase in acute, thrombotic manifestations of the disease, caused by plaque rupture. These thrombotic 
manifestations result in more mortality and morbidity than the non-thrombatic disease states caused by atherosclerosis.

The aim of the current thesis is to further elucidate the pathogenesis of atherosclerosis. It concentrates on the role of cell fumover and inflammation in lesion initiation, progression and phenotype. Experiments were pertormed on human atherosclenotic tissue obtained during autopsy or wascular surgery, or in mouse models of atherosclerosis. Interventions in these mouse models comprise genetic disruption studies and antibody studies.

In this general introduction, the pathogenesis of atherosclerosis, including the 'response to injury' hypothesis, histological classification, and vascular remodeling will be discussed, followed by an overview of the most commonly used mouse models of atherosclerosis. Subsequently, background information will be provided on the process of cell turnover in general, and specifically in vascular disease, followed by a description of inflammation with a focus on the CD40-CD40L system, and its role in vascular disease. Finally, the hypothesis of the thesis will be outlined.

\section{Pathogenesis}

\subsection{Introduction}

During the last two centuries, clinicians and researchers have been fascinated by the process of atherosclerosis. The first investigations were performed by pathologists. In 1858, Virchow, the founder of cellular pathology, presented a lecture on the 'atheromatous affection of arteries'. He distinguished 3 processes. At first, the simple fatty metamorphosis, which is characterized by the transformation of the existing histological elements into a state of fatty degeneration. Second, the stage of irritation, comparable to the stage of swelling, and enlargement, seen in other states of inflammation. Lastly, the stage of atheromatous degeneration, with cholestearine plates, granule cells and fat granules, and hard lumps of half softened substance resulting in the pultaceous character of the atheromatous matter. ${ }^{26}$ in 1908, sir William Osler, the pioneer of internal medicine stated that the stability of tubing of any sort depends on the structure and on the sort of material used: and so it is with the human being. With the poor variety of elastic and muscular fibers in the blood vessels, some are unable to resist the wear and tear of daily life... in time they become old, in threescore or fourscore years the limit of their endurance is reached and they wear out', 27

Nowadays, we have a more profound knowledge of processes and features of the different stages of atherosclerosis, but many aspects are based on the observations of ancient research described above. This outine will focus on the pathogenesis of atherosclerosis. First, the 'response to injury' theory will be discussed. followed by a description of the latest histological classification, an overview of the site and age dependent progression of atherosclerosis and lastly, the aspects of remodeling of the entire vasculature during atherogenesis. 


\subsection{Response to Injury}

One of the most important theories, that has contributed to a better (molecular) understanding of the pathogenesis of atherosclerosis is the 'response to injury' hypothesis. In 1973, the group of R. Ross postulated that atherosclerosis is the result of endothelial denudation. ${ }^{28}$ They hypothesized that endothelial denudation caused migration of smooth muscle cells (SMCs) into the intima, followed by proliferation of these cells, increased lipid deposition and extracellular matrix synthesis. ${ }^{28,29}$ This hypothesis was derived from the observation that ballooncatheter induced arterial denudation in macaque monkeys resulted in the development of "fibromusculoelastic lesions" (fig. 1,1). . $^{30}$

Over the years, the hypothesis was adapted to newer insights. In 1993. endothelial dysfunction triggered by shear stress and $(O x) \mathrm{LDL}$, rather than denudation was considered to be the trigger of atherogenesis ${ }^{31,32}$ Furthermore, besides the SMC and endothelial cell, macrophages and T-ly/mphocytes were considered to play major roles in the disease process. Molecules considered to act in cell recruitment, migration, proliferation, apoptosis and the control of lipid and protein synthesis were growth factors (PDGF, bFGF, IGF, TGF ) and cytokines (IL1, TNF $\alpha$, IL2, IFN $\gamma$ ) (fig. 1.1).

Nowadays, endothelial activation, and the subsequent chronic inflammatory response, comprising upregulation of the immune system, is considered to play the major role in the progression of atherosclerosis. ${ }^{33}$ The most important players responsible for the initiation and progression of atherosclerosis are the macrophage and the T-iymphocyte. Endothelial activation induces upregulation of leukocyte adhesion molecules (like P- and E-selectin, ICAM-1 and VCAM), that mediate monocyte recruitment into the intima. Also, growth factors (PDGF, bFGF, IGF, TGF3), chemokines (MCP-1, IL8) and cytokines (IL1, TNF $\alpha$, IL2, IFNr, gm-CSF, M-CSF) mediate the differentiation of monocytes into macrophages, the transition into macrophage derived foam cells, and the activation of macrophages and $T$ lymphocytes. Furthermore, these molecules are responsible for recruitment and proliferation of cells into the intima, apoptosis of these cells and the synthesis and degradation of the extracellular matrix (fig. 1.1).

\subsection{Progression of atherosclerosis according to the AHA classification of 1995}

Since the 1950s, several histological classifications have been developed. The most recent, published in 1995 and updated in 2000, was developed by the Council on Arteriosclerosis, Thrombosis and Vascular Biology of the American Heart Association. ${ }^{1.4 .34-36}$ It is based upon the principles of the 'response to injury' theory outlined above. This classification divides the pathogenesis of atherosclerosis into six different stages, based on histological characteristics (fig. 1.2 and 1.3). Type 1-1II lesions comprise initial atherosclerotic lesions, that are clinically silent, while type $\mathrm{IV}$ and $\mathrm{V}$ lesions, are advanced stable or instable atherosclerotic lesions, that both can progress to the clinically most dangerous type $\mathrm{V} /$ (thrombotic) lesions. ${ }^{4,33,34}$

Atherogenesis starts with monocyte adhesion to the endothelium, diapedesis of monocytes into the intima (that differentiate into tissue macrophages) and accumulation of lipids into these macrophages (foam cells). This stage is called the 


\section{Evolution of the 'Response to Injury' hypothesis}

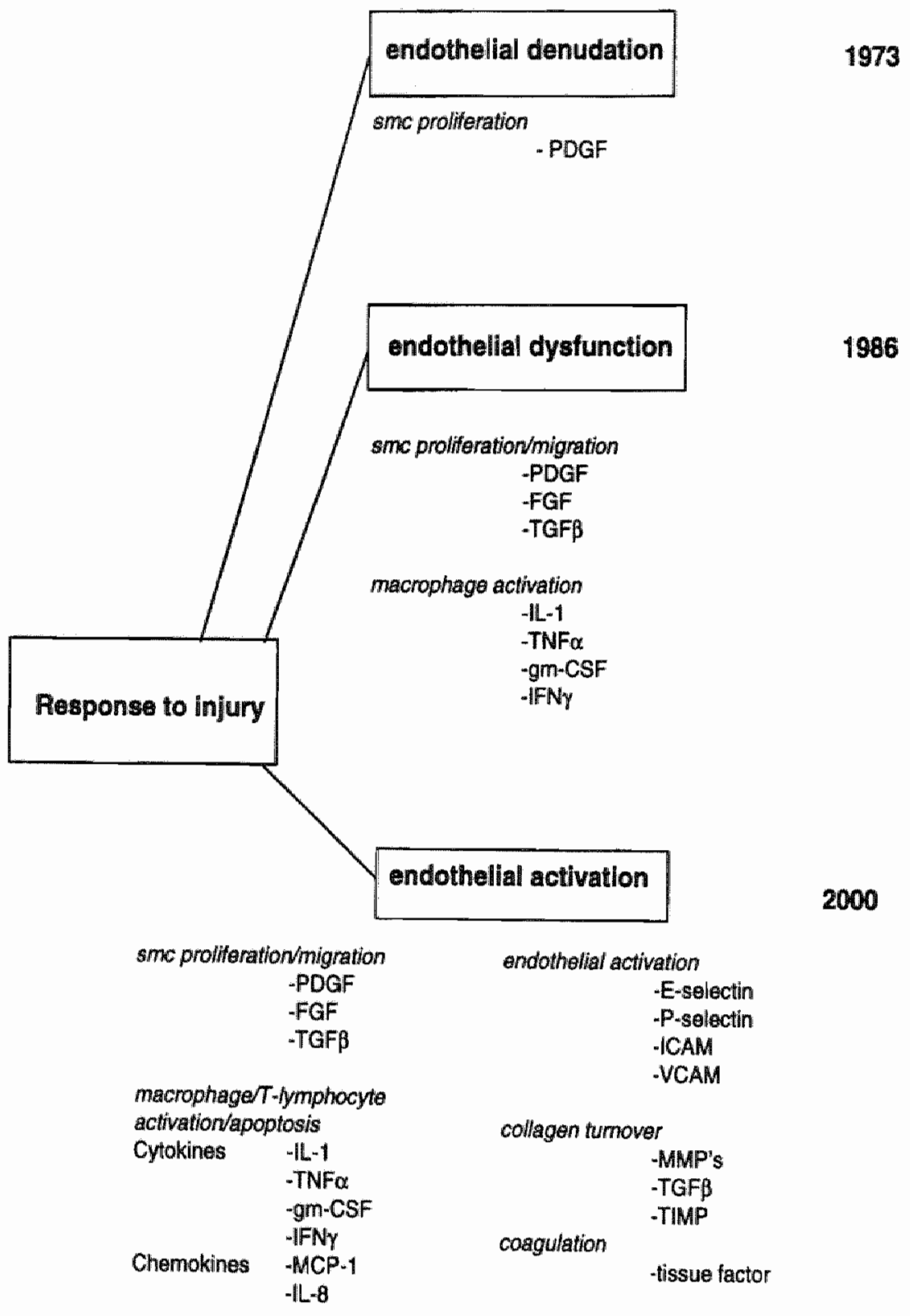

Fig. 1.1

Evolution of the 'response to injury' hypothesis in the last three decades, based upon reviews by $R$.
Ross. 


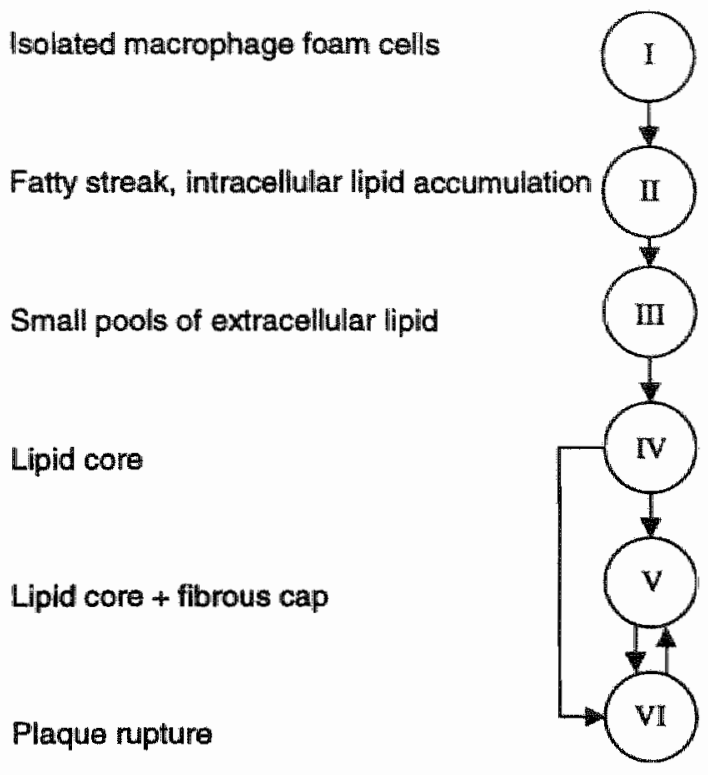

Fig. 1.2

Progression of atherosclerosis according to the AHA classification of 1995

fatty streak, or, according to the AHA, a type I-ll lesion. Macroscopically, these lesions look like small lipid yellow dots. ${ }^{4,34,37.38}$ They have been reported to occur as early as in infancy and childhood. ${ }^{1-3}$ When monocyte recruitment continues, the fatty streak lesion progresses into a type III lesion, a plaque containing also extracellular lipids (pre-atheroma) ${ }^{34}$ Further progression results in the development of advanced atherosclerotic lesions. The first advanced stage of atherosclerosis, prone to become clinically symptomatic is the atheroma (type IV lesion). The type IV lesion contains a necrotic core with extracellular lipids and cholesterol-ester crystals. ${ }^{4}$ During the progression of atherosclerosis, (myo)fibroblasts and SMCs migrate into the intima and form, together with extracellular matrix elements (collagen), a fibrous cap that overlies the atherosclerotic plaque. This lesion type is called the fibro-atheroma (type $V$ lesion). Type $V$ lesions are subdivided into $\mathrm{Va}$ (large lipid core), $V_{b}(=\mathrm{V} \mid \mathrm{I})$ (calcification) and type $\mathrm{V}_{\mathrm{c}}\left(=\mathrm{V} / \mathrm{ll}\right.$ )(fibrous). ${ }^{4}$ Type $\mathrm{V}$ and $\checkmark$ lesions can either have a stable plaque morphology, characterized by a thick fibrous cap, high SMC/collagen content, a low amount of T-lymphocytes, and a small lipid core, or an unstable plaque morphology, which is characterized by a thin fibrous cap, a large lipid core, a low SMC/collagen content, a low amount of $\mathrm{T}$ lymphocytes, and a thin media. ${ }^{7.33,39}$ The thin fibrous cap of unstable type IV and type $V$ lesions is prone to rupture, thereby exposing the thrombogenic material of the lipid core. The resulting lesion type is the clinically most symptomatic type $\mathrm{V} /$ lesion 
Type I

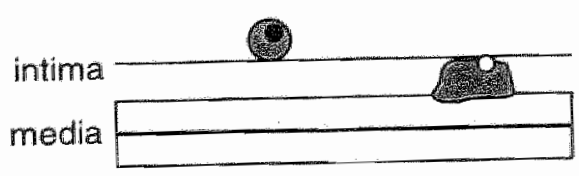

Type III

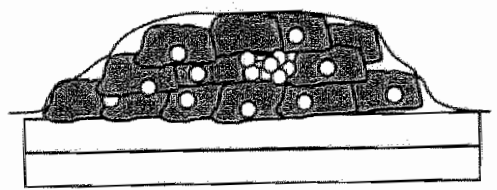

\section{Type V}

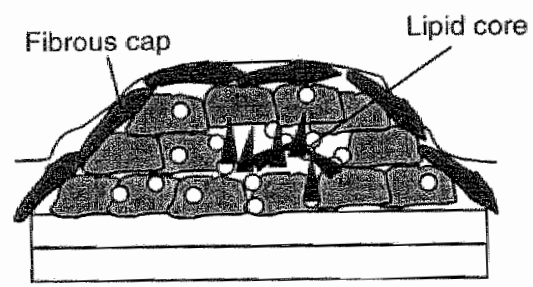

Type II
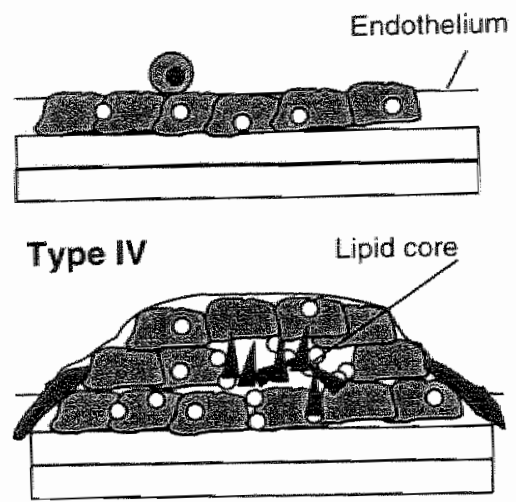

Type VI

Fibrous cap

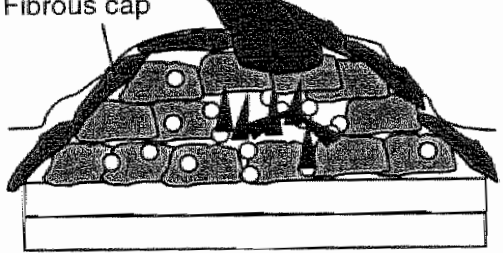

\section{Legend \\ endothelium \\ (19) monocyte \\ Macrophage \\ derived \\ toam cell}

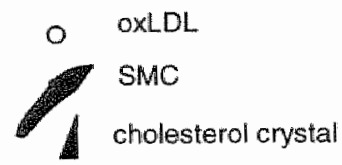

Fig. 1.3

Figure describing the most important features and cell types of the six different stages of atheroscierosis according to the AHA classification of 1995

(complicated lesion) (fig. 1.2 and 1.3). . $^{4,7}$ Type $V /$ lesions are ruptured atherosclerotic plaques, characterized by fissures, hematoma and thrombus formation, causing occlusion of the vessel lumen. This causes acute ischemia often restulting in necrosis and loss of function of the affected organ. Type VI lesions are therefore associated with most of the morbidity and mortality caused by atherosclerosis. 433

Recently, Virmani ef al proposed some modifications to the AHA classification of 1995, since autopsy studies revealed a number of lesion types that are difficult to detine by the present classification, especially the advanced atherosclerotic 18 
lesions. ${ }^{35}$ For example, the distinction between type IV and $V$ lesions is often difficult, when a thin fibrous cap is present. Instead of type IV, or instable type $V$. the modification proposes to call it a "thin fibrous cap atheroma'. Type VI lesions comprise ruptured plaques, with thrombus formation. However, plaques showing thrombus are often not ruptured, but only show plaque erosion. Therefore, the modification proposes three different terms for the former type VI lesion. First; it distinguishes the "fibrous cap atheroma with erosion", which contains a thick fibrous cap with a luminal thrombus, but shows no communication of the thrombus with the necrotic core. Second, the 'thin fibrous cap atheroma with plaque rupture', in which the fibrous cap is ruptured and the luminal thrombus communicates with the underlying lipid core, and third, the 'calcific nodule with erosion' with an eruptive nodular calcification with overlying luminal thrombus. 35 These modifications should not be used as an alternative classification, but as a way to describe features of atherosclerotic lesions of a specific AHA type in more detail.

\subsection{Age and site specific progression}

In humans, the first atherosclerotic plaques develop at sites with adaptive intimal thickening. These sites include arterial branches, curvatures and bifurcations, sites at which alterations of blood flow occur, such as decreased shear stress and increased turbulence. ${ }^{40}$ Also, in animal models of atherosclerosis, plaques develop at these specific sites. ${ }^{4-43}$ The ApoE-1- mouse (the most frequently used hyperlipidemic mouse model) shows a cranio-caudal atherosclerotic lesion progression, starting at the aortic arch and its main branchpoints and progressing to the femoral arteries. ${ }^{41}$ The lesions typically develop in low shear stress areas of the vasculature, i.e. the low flow side of branch points and the lesser curvature of the aortic arch. ${ }^{41}$ in humans, a detailed report regarding the progression of atherosclerosis throughout the arterial tree is still lacking. However, the first significant atherosclerotic plaques seem to develop in the coronary and carotid arteries, and also the abdominal aorta is prone to develop lesions, most probably because of its many branchpoints and its different composition compared to the thoracic aorta. The thoracic aorta diameter is larger than that of the abdominal aorta, and has a larger number of transmedial lamellar units. The thoracic aorta also contains relatively more elastin and less collagen than the abdominal aorta, which is therefore stiffer and less compliant. ${ }^{45}$

Fatty streak lesions. (AHA type I and II) in the coronary arteries are already observed in $45 \%$ of children in the first 7 months of life. 3.46 At the age of 1 , these lesions disappear, to reappeai more substantially in $53 \%$ of the individuals at puberty. ${ }^{2,46}$ Advanced atherosclerotic plaques (type $\| I 1-V I$ ), although not clinically symptomatic, are present from the third decade of life (3.4\%). These plaques increase in number and can progress into clinically significant lesions during the following decades of life. 2.46 


\subsection{Remodeling}

For a long time, the arterial system was considered to be a rigid tube that exhibited luminal narrowing in response to a growing plaque mass. However, in 1987, Glagow, and many others thereafter, reported that coronary arteries show compensatory enlargement with maintenance of the vessel lumen in response to plaque progression. It was stated that the capacity of the vessel wall to show compensatory enlargement was limited, and that when the limit of $40 \%$ stenosis has been reached, luminal narrowing would develop. ${ }^{47}$ Now we know that compensatory enlargement, also termed outward remodeling, as well as constrictive remodeling can occur ${ }^{48-50}$ The mode of remodeling (compensatory vs constrictive) varies strongly over the length of the same artery, between the different arteries, and between different individuals. ${ }^{48,51,52}$ Compensatory enlargement prevents, and constrictive remodeling accelerates narrowing of the lumen, inducing clinically significant stenoses. ${ }^{53,54}$ Interestingly, arterial cross-sections with a large atherosclerotic plaque and massive compensatory enlargement showed histological features of plaque instability, like more inflammation, large necrotic cores and thin fibrous caps $s^{55,56}$ suggesting that a large lumen at angiography not always reflects a non- or less-diseased vessel.

Mechanisms of arterial remodeling in primary atherosclerosis are largely unknown, and most of the postulated mechanisms are derived from observations in balloon injured animals. In primary atherosclerosis, plaque growth narrows the lumen and shear stress changes. The endothelium reacts by producing vasodilators (for example NO), and compensatory enlargement develops. ${ }^{57}$ When this mechanism does not suffice, inadequate compensatory enlargement will ensue ${ }^{58-61}$ In addition, it is reported that decreased blood flow causes arterial wall shrinkage (constrictive remodeling), but precise mechanisms are largely unknown.62,63

On the other hand, compensatory enlargement is thought to result from involution of the support structure of the arterial wall. ${ }^{64,65}$ During atherogenesis, collagen, as well as elastin is degraded. This often results in an atrophic, elastolytic media and decreased collagen content in the adventitia. Matrix degrading substances, responsible for media degradation are MMP-3, $-9,-12$ and $-13^{66}$ As a response, the artery is able to enlarge, often resulting in aneurysm formation. ${ }^{64,66,67}$

Although compensatory and constrictive remodeling has been extensively reported in different animal models after balloon angioplasty, like the baboon ${ }^{68,69}$, the rat, the rabbit ${ }^{70}$ and the $\mathrm{pig}^{71}$, an animal model of de novo atherosclerosis that shows constrictive remodeling together with significant stenosis is still lacking. So far. the majority of animal models of primary atherosclerosis, only show compensatory enlargement, but fail to show significant stenosis or constrictive remodeling. ${ }^{63,70,72}$ ApoE- $\%$ mice show compensatory remodeling, and even aneurysm formation in the thoracic, abdominal and common carotid artery. .6.73 $^{2}$ Interestingly, luminal narrowing, although not significant, was observed in the external carotid artery in 9 of 12 animals tested ${ }^{73}$, indicating that the evaluation of constrictive remodeling in this mouse model warrants further investigation. 
Numerous animal species have been used to study the pathogenesis of atherosclerosis. Until the 1990 s, research was restricted to relatively large animals, such as non-human primates $s^{42.74}$, swine ${ }^{75.76}$, rabbits ${ }^{77.78}$, hamsters ${ }^{79}$ and pigeons ${ }^{43}$. Also, the balloon-injured rat was used, sometimes in combination with hypercholesterolemia, although those lesions rather reflect the process of neointimai hyperplasia than primary atherosclerosis. ${ }^{80,81}$ The large animal models present particular problems, like their non-reproducibility, expensive housing, and rather non-human like atherosclerotic lesions.

Since the 1990s, the mouse is evolving as an animal model for atherasclerosis. Since the development of transgene and knockout technology, mouse models have become very popular, since mice are relatively cheap, small, genetically homogeneous and can easily be used for studies of possible therapies that require large numbers of animals. Another advantage of the use of transgenic and knockout mouse models is the possibility of studying the effect of single gene mutations, for instance by cross-breeding several knockouts.

Before transgene technology, the only mouse model that was used in atherosclerosis research, was the $\mathrm{C} 57 \mathrm{B16}$ mouse. ${ }^{82.83}$ This mouse model exhibits some features of atherosclerosis when fed an atherogenic diet. Lesions of this mouse are small, and usually restricted to the root of the aorta, and associated with the cusps of the valves. ${ }^{82,83}$

In 1992, the ApoE deficient mouse was developed, created by homologous recombination in embryonic stem cells. ${ }^{84.85} \mathrm{ApoE}$ is one of the apolipoproteins that coats the surface and mediate the metabolism of lipoprotein particles. ApoE mediates the clearance of VLDL and LDL and chylomicrons from plasma. Consequently, mice deficient in ApoE exhibit high plasma cholesterol levels (predominantly VLDL and IDL) and spontaneously develop atherosclerotic lesions throughout the arterial tree from 10 wks of age. ${ }^{41}$ Upon feeding an atherogenic diet, lesion development is accelerated. ${ }^{41}$

In 1993, another atherosclerotic mouse model was developed, the LDL-receptor deficient mouse. ${ }^{86}$ As in humans with this genetic defect (type III hypercholesterolemia), these mice exert high levels of total cholesterol, predominantly in the IDL and LDL fractions. ${ }^{86}$ LDL-receptor deficient mice develop atherosclerosis upon atherogenic diet. Compared to ApoE-/- mice, LDL-receptor deficient mice develop atherosclerosis more slowly. The first advanced atherosclerotic lesions are found at 8 months of age.257

In addition to these two basic hyperlipidemic mouse models, other variants have been deveioped. One of these mouse models is the ApoE*3Leiden mouse. The ApoE"3Leiden gene was originally discovered in a family exhibiting familial dysbetalipoproteinemia ${ }^{87}$ Compared to the normal ApoE gene, the ApoE*3Leiden gene contains a tandem duplication of codons 120-126 in the ApoE gene. The presence of a single allele for this mutation results in the development of familial dysbetalipoproteinemia in patients. ${ }^{89,89}$ The transgenic mouse model, carrying this human ApoE*3Leiden gene, exhibits high levels of cholesterol (predominantly VLDL 
and IDL) and triglycerides.90 These mice develop intial and advanced atherosclerosis, but only after being ted an atherogenic diet ${ }^{92}$ An important difference with the ApoE-1- mouse is the fact that ApoE*3Leiden mice still carry their own functional ApoE gene. Therefore, it is postulated that their atherosclerotic lesions are still capable of reversed cholesterol transport ${ }^{90-92}$

The hyperlipidemic mouse models as described above show many similarities with human atherosclerosis. First of all. they develop human-like advanced atherosclerotic lesions, containing a fibrous cap and a lipid core. Second, the cellular composition of their plaques resembles human atherosclerasis, since mouse atherosclerotic lesions contain macrophages. SMCs, T-lymphocytes, endothelial cells and fibroblasts. Third, as in humans, atherosclerotic lesions predominantly develop at aortic branchpoints and bifurcations. However, there are also major differences. Arterial geometry, flow- and shear-patterns structurally differ between mice and humans. Compared to human atherosclerotic plaques, mouse lesions show an increased cellularity, and an increased amount of macrophage derived foam cells. Ruptured atherosclerotic plaques, as well as plaque hemorrhage are not observed in any of the animal models described above. Consequently, complications of atherosclerosis like cerebral- and myocardial infarctions are very uncommon in these models. Therefore, extrapolation of mouse data to human coronary or peripheral atherosclerosis should be applied with caution. 


\section{This thesis}

Although the "response to injury" hypothesis is continuously being adapted to the newest insights in the pathogenesis of atherosclerosis, precise mechanisms responsible for lesion initiation and progression are still incompletely understood. Mechanisms are multiple, complex and the different mechanisms most likely form a network of events interrelating and influencing each other. Elucidation of these mechanisms in detail and their (inter)actions may provide new therapeutic targets for inhibiting initiation and progression of atherosclerosis, or for inhibiting the ransformation of stable into unstable plaques.

This thesis focusses on two mechanisms that are considered to play a major role in the pathogenesis of atherosclerosis. The first mecharism is the balance between DNA-synthesis and apoptosis, and the second mechanism is the influence of chronic inflammation and the immune system. To provide the background for the experimental observations reported in this thesis, we will describe the two mechanisms below. Paragraph 4 focusses on the role of cell turnover (DNAsynthesis and apoptosis) during atherogenesis and paragraph 5 focusses on the role of inflammation, in particular the role of the CD40-CD40L system in atherosclerosis.

\section{Cell Turnover}

\subsection{Introduction}

DNA-synthesis (proliferation) and apoptosis are two important processes in embryonic development, normal growth and development and, when an organism has reached maturity, in cell repair processes. At that time, cell turnover occurs as a response to injury, cell death or mechanical deformation. The processes of DNA synthesis and apoptosis are tightly regulated, and disturbances in the process can have disastrous effects. For example, congenital abnormalities are often the result of disturbances in DNA-synthesis and apoptosis. Furthermore, several diseases, llike cancer and fibro-proliferative diseases, but also cardiovascular diseases, are characterized by an altered balance between DNA-synthesis and apoptosis.

\subsection{DNA-synthesis}

\subsubsection{Cell cycle}

To a great extent, the mechanism of cell division is comparable in all dividing cells, and has been conserved during evolution. The cell cycle is divided into five phases. It consists of the GO (gap0), G1-(gap1), S- (DNA-synthesis), G2- (gap2) and the Mphase (mitosis and cytokinesis). G0, G1, S and $\mathrm{G} 2$ are called the interphase. Quiescent cells are found in the Go phase and are in a state where mRNA and protein synthesis are minimal. When stimulated, cells enter the G1 phase, in which the cell generates mRNAs and proteins that are necessary for DNA-synthesis. The S-phase is the period during which the genetic material is replicated, and $G 2$ the period during which the fidelity of DNA replication is determined and errors are corrected. After the interphase, the cell proceeds to the M-phase, during which cells divide into two daughter cells (fig. 1.4) 


\subsubsection{Cell cycle regulators}

The cell cycle is tightly regulated by the sequential formation, activation, and inactivation of a series of cell cycle regulatory proteins to minimize errors in the replication process. These proteins include a group of regulatory subunits called the cyclins, and a group of calalytic kinase subunits known as cyclin dependent kinases (cdks). The enzymatic activity of the cok is determined by the association with a cyclin. There are at least $7 \mathrm{cdk}$ families, each of which associates with a distinct cyclin mollecule. The resulting complexes have characteristic substrate specificities, and are expressed in different stages of the cell cycle "thereby driwing the cell from one stage to another.

The cyclinB/cdc2 complex is the primary regulator of transition from $\mathrm{G} 2$ to the $M$ phase. It is activated by a cdk activating kinase (CAK) and phosphatase (cdc25) that removes inhibitory phosphates. Activation of this complex results in chromosome condensation, nuclear membrane breakdown and spindle formation (fig. 1.4).

The regulation of the entry G1 to S is complex. Two cyclin/cdk complexes, cyclin D/cdk4 or -6 , and cyclin E/cdk2, phosphorylate the retinoblastoma gene product (Rb), and alter the ability of Rb to bind with cellular proteins. One such protein is E2F, a transcription factor that heterodimerizes with other transcription products. such as DP1, and activates several genes required for $S$ progression, including thymidine kinase, DNA-polymerase $\alpha, c$-myc, c-myb, and cdc2 (fig. 1.4).

The activity of cok's is also regulated by cdk inhibitors. These low-molecular weight proteins either inhibit cok activity broadly $\left(p_{21} 1^{\text {Cip } 1 / \text { wat1 }}, p 27^{\text {kip } 1}, p 57^{\text {Kip2 }}\right)$ or selectively inhibit cyclin D/cik4 or -6 complexes ( $\left.p_{1} 6^{\text {NKK } 4 a}, p 15^{\text {INK } 4 b}, p 18\right)$. The best known member of this family is $\mathrm{p} 21$. It inhibits both cok's and proliferating cell nuclear antigen (PCNA). P21 is induced by DNA damage through transcriptional activation by $\mathrm{p} 53$, and inhibits cell cycle progression at several points (fig. 1.4), and permits DNA repair to take place. P53 is seen as "the guardian of the genome". When DNA-damage takes place, p53 influences transcription to either halt cell cycle progression (by induction of p21), to permit repair of DNA, or, if the damage is too large, to induce apoptosis.

The behaviour of the cell in an organism is tightly regulated by its environment Cell cycle processes are stimulated or inhibited by extracellular substances, like growth factors (PDGF, bFGF. EGF. TGFB, angiotensin II, hormones and cytokines (TNFo). After binding to their surface receptors, these substances induce several signalling pathways that convert extracellular signals into a specialized cell cycle action in the responding cell. ${ }^{23}$ 


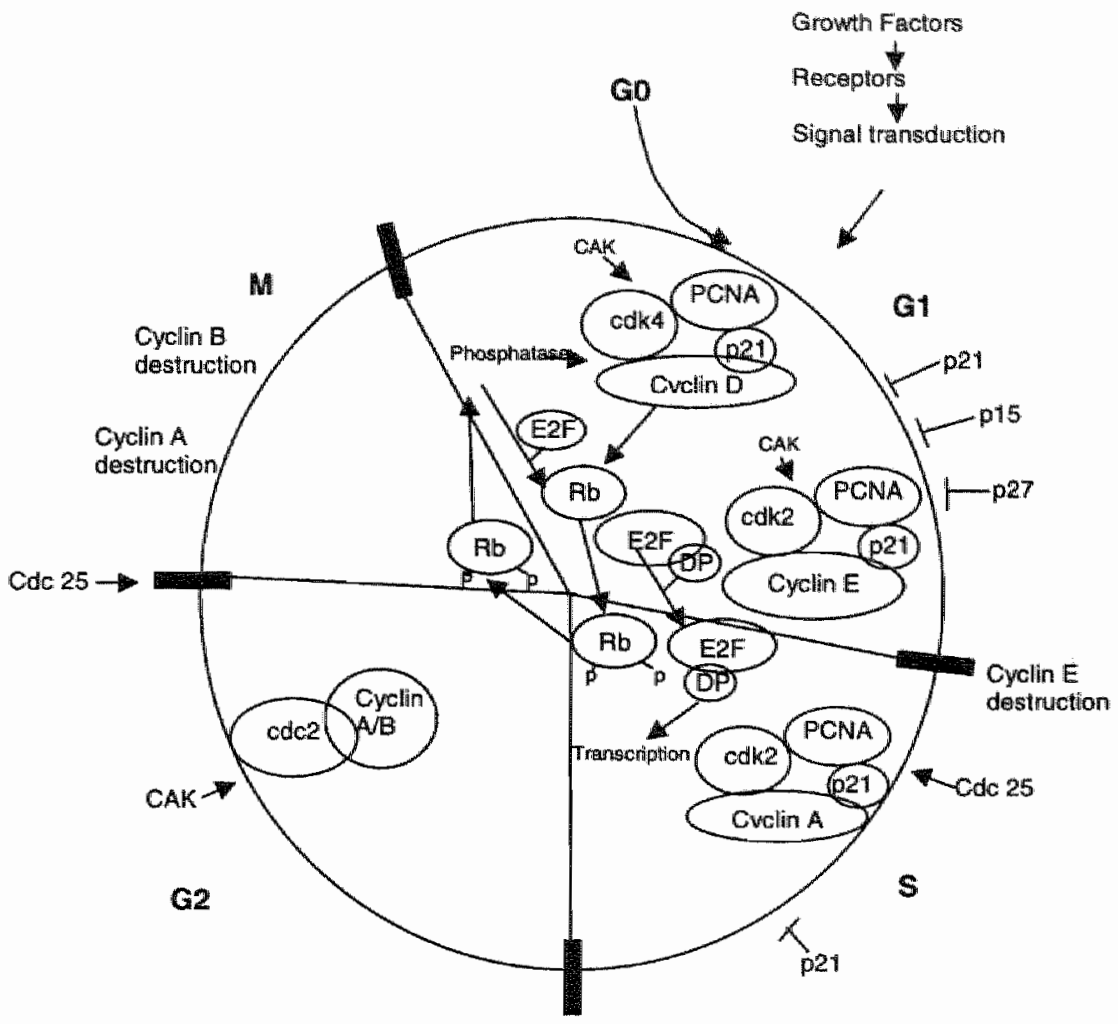

Fig. 1.4

The cell cycle: most important regulators

\subsection{DNA-synthesis and vascular disease}

\subsection{DNA-synthesis and arterial injury}

In 1973. Ross postullated in his 'response to injury' hypothesis that intimal changes during atherosclerosis and restenosis were the result of excessive DNA-synthesis of SMCs. ${ }^{28,94}$ This hypothesis was supported by observations in many animal models of arterial injury.

\subsubsection{DNA-synthesis and animal models of arterial injury}

One of the most widely used animal models of arterial injury, is balloon injury in the carotid artery of the rat. In this model, a catheter is inserted into the carotid artery, inflated and pulled back, thereby inducing endothelial denudation and medial damage. ${ }^{95}$ Subsequently, 3 waves can be distinguished. The first response to balloon injury consists of medial SMC DNA-synthesis and begins $\approx 24$ hours after the event. Four days thereafter, SMCs start migrating into the intima. Once arrived, SMCs replicate for weeks to months. ${ }^{95-98}$ in other models of arterial injury, like pigs. 
rabbits and non-human primates, the same pattern was observed ${ }^{99}$ Animal models of vein graft arteriosclerosis, show a comparable SMC-rich neointima, and elevalled levels of DNA-synthesis were also observed. ${ }^{100.10:}$

Factors inducing DNA synthesis in vivo after balloon angloplasty or graft

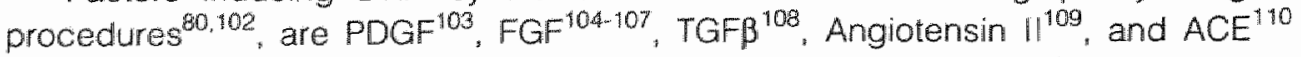
(table 1.1). Other molecules, gaining increasing interest in vascular disease are Gas6 (growth arrest specific gene 6) and its tyrosine kinase receptor Axt (table 1.1). Gas6 was originally identitied as a gene that was differentially expressed in serum-starved fibroblasts, and that acts as a survival factor. 12 However, Gas6 seems to affect cell turnover in a cell type dependent manner. For example, Gas6 is mitogenic in the presence of low serum for fibroblasts ${ }^{113.114}$ and Schwann cells ${ }^{115}$, but not for myeloid cells ${ }^{116}$, or endothellal cells ${ }^{117}$. Interestingly increased expression of Gas6 and AxI was observed after arterial balloon injury in rats, and in vitro studies reveal that Gas6 acts as a chemoattractant for human and rat SMCs. ${ }^{118,119}$

Atter binding of these growth factors to the receptor, an intracellular signalling pathway is elicited, thereby transducing signals into the nucleus to stimulate the cell cycle. Most of the growth factor receptors belong to the receptor tyrosine kinase family, with the MAP kinases ERK and JNK, c-fos and c-jun, as important downstream elements. ${ }^{120}$ Expression or intervention studies involving (downstream) members of the receptor tyrosine kinase family in balloon injured animal models revealed a significant role for these molecules in SMC replication after arterial injury

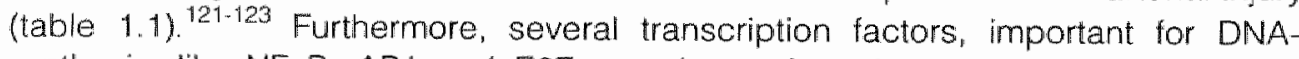
synthesis, like $N F \kappa B, A P 1$ and $E 2 F$ are also activated after arterial injury (table 1.1). $121,123 \cdot 126$

Downstream, activation or inhibition of cell cycle regulators promoted or inhibited SMC DNA-synthesis. Cell cycle regulators that are known to be involved in neointima formation are p27, cdk2, cyclinA, p21, PCNA. ${ }^{127-132}$ Cell cycle regulators are easy targets for the use of gene therapy. ${ }^{130,133,134}$ For example, adenovirus mediated expression of $\mathrm{p} 21$, and administration of antisense oligodeoxynucleotides for E2F succesfully inhibited neo-intima formation in balloon injured rats, and in rabbit vein grafts (table 1.1). $124,127,129,135$

\subsubsection{DNA-synthesis in human neo-intima formation}

in humans, acute arterial injury is induced by procedures aimed at restoration of adequate blood flow like PT(C)A, arterial or venous bypass graft surgery, and endarterectomies. Immediately after these procedures, blood flow is restored successfully. However, as a 'response to injury' a neointima develops, resulting in restenosis or re-narrowing of $20-60 \%$ of the arteries within 6 months, depending upon the type of revascularisation procedure and the artery involved. ${ }^{136}$ The neointima is SMC rich, and resembles the lesions observed after experimenta balloon angioplasty or graft procedures in animal models. ${ }^{136}$

Human restenotic lesions show an increased expression of growth factors ${ }^{106,137,138}$, and cell cycle regulatory proteins ${ }^{139,140}$, that can induce SMC DNAsynthesis (table 1.1). In human restenotic lesions, DNA-synthesis is however rather 
low: probably because lesions are investigated months after arterial injury. Therefore, an early proliferative response may have been missed. ${ }^{141,142}$ ONA. synthesis in these lesions was contined to the SMC. "In humans, interventions with DNA-regulatory proteins have been performed. ${ }^{47,143}$ Although some were successtul in inhibiting the process of neointimal formation. data on the level of DNA-synthesis in these lesions are scarce (table 1.1$).^{144}$ Inhibition of PDGF and DFGF after PTCA ${ }^{137}$, as well as administration of oligonucleotides inhibiting E2F (E2F decoy) in human vein grafts were abie to inhibit DNA-Synthesis and thereby: restenosis or recurrent graft occlusion. ${ }^{143}$

\subsubsection{DNA-synthesis and primary atherosclerosis}

As in restenosis, primary atherosclerosis results from an endothelial response to injury, followed by excessive DNA-synthesis. However, the pathogenesis of primary atherosclerosis differs compared to that of restenosis. Primary atherosclerotic lesions develop more slowly. and endothelial denudation is less rigorous. Furthermore, atherosclerotic lesions mainly consist of macrophage derived foam cells, and SMCs are present in a lower amount. ${ }^{136}$

\subsubsection{DNA-synthesis in animal models of primary atherosclerosis}

Compared to balloon injured animals, DNA-synthesis in hypercholesterolemic animal models, such as rabbits and pigs, is lower, but still significantly elevated compared to the non-diseased arterial wall. ${ }^{145-147}$ in these animal models, DNA. synthesis was not confined to the SMC, but was predominantly observed in macrophage derived foam cells. ${ }^{145,147}$ In hypercholesterolemic rabbits, most DNAsynthesizing nuclei were present in the luminal layer, rich in macrophage derived foam cells, while no DNA-synthesizing cells could be observed in the lipid core region. ${ }^{145.147}$ Most DNA-synthesizing cells were found in early atherosclerotic lesions, and their number decreased in more advanced atherosclerotic lesions. ${ }^{147}$

Factors known to induce or repress DNA-synthesis in the rat balloon injury model, like PDGF, TGFB, FGF, angiotensin $\|$, receptor tyrosine kinase signalling molecules, transcription factors, and cell cycle proteins (p53, p21,p27, cdk2, cyclin A) were also expressed in atherosclerotic lesions (table 1.1). ${ }^{14 \%-154}$ However. intervention studies with DNA-synthesis inhibiting agents are scarce, and mostly fail to reduce DNA-synthesis (table 1.1).

\subsubsection{DNA-synthesis in human atherosclerosis}

In human atherosclerotic lesions, DNA-synthesis is low $(0-3.5 \%)^{141.142 .155-159}$ This low level of DNA-synthesis might be expected in lesions that take many years to become clinically manifest. Most of the studies on DNA-synthesis during atherogenesis were performed on advanced atherosclerotic lesions. In these lesions, the cell types that exhibited DNA-synthesis were either the macrophage derived foam cell ${ }^{155-157}$ or the SMC. ${ }^{141}$ Interestingly, an in vitro study, using either fatty streak or fibrous plaque derived cells, showed that DNA-synthesis in fatty streak lesions was much higher ${ }^{160}$, indicating an early proliferative response in atherosclerosis. 


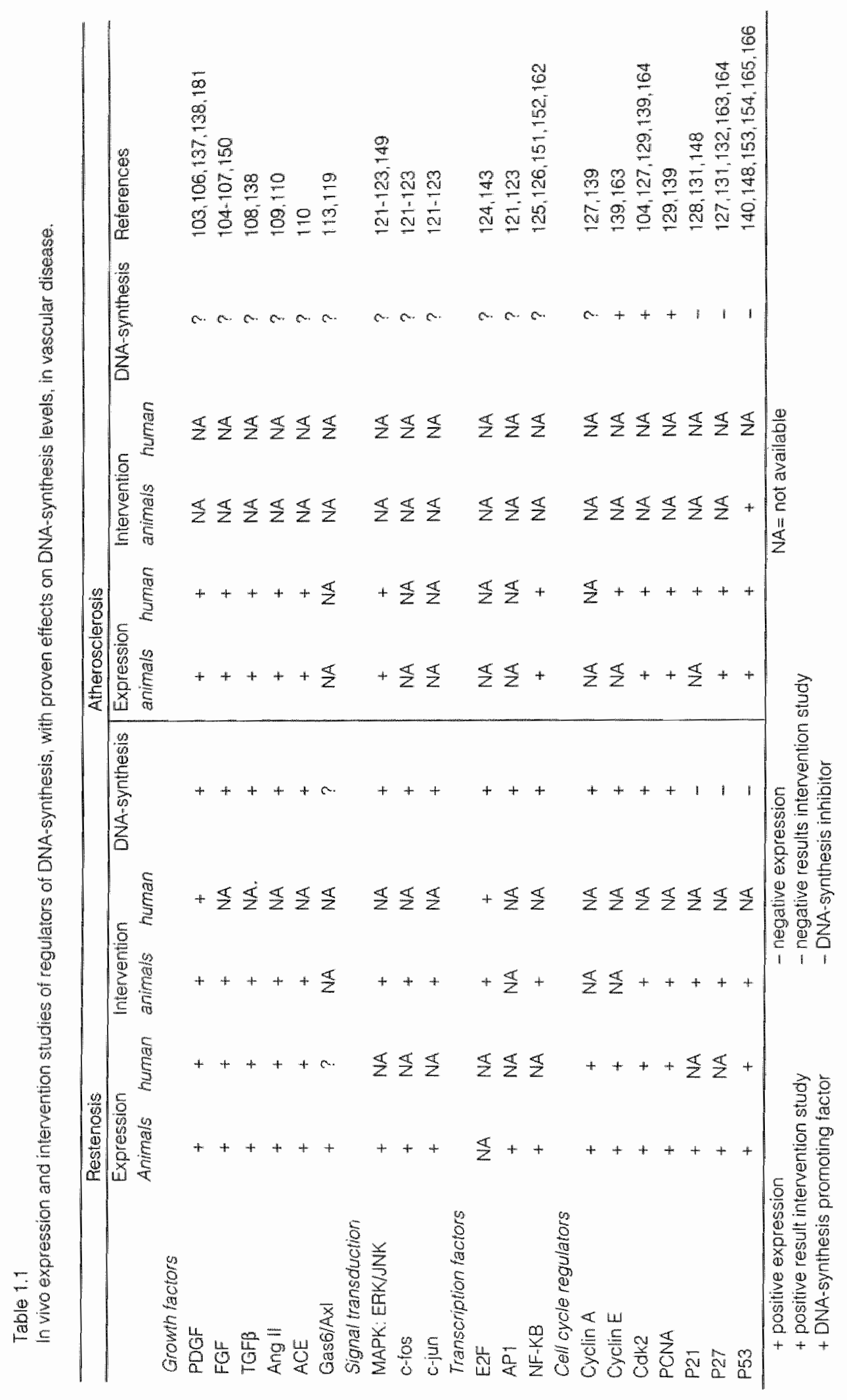


The distribution of DNA-synthesizing cells in the atherosclerotic lesion is largely unknown, since most of the studies have been performed on atherectomy specimens, which lack decent lesion morphology. However, topographical analysis revealed that DNA-synthesis was tightly correlated with areas of structural repair and foam cell infiltration. ${ }^{155,157,158}$

Also, in human atherosclerotic lesions enhanced expression of growth factors (PDGF, FGF, TGFB, Angll, ACE) ${ }^{106,110,138,161}$, elements of the receptor tyrosine kinase pathway (dr. S. Heeneman, personal communicalion), transcription factors $(\mathrm{NF} K \mathrm{~KB})^{162}$, and cell cycle regulatory molecules (cyclinE, cdk2, PCNA, p21, p27. p53) ${ }^{148,163,164}$ was observed. However, intervention studies with DNA-synthesis regulating agents in primary atherosclerosis are scarce, and data on its effects on DNA-synthesis are not available (table 1.1).

\subsection{Apoptosis}

The homeostasis of organisms requires a balance between the generation of new cells and cell death. Cells can die when they have sustained sufficient hypoxic, heat, oxidative, or ultraviolet damage that cannot be repaired. A cell can be killed if it becomes infected with a virus or another intracellular pathogen that destroys the cell or is recognized by the hast's lymphocytes, which will kill the infected cell. In multicellular organisms, cell death is an essential component of normall development and cellular regulation. Abnormal regulation of cell death can lead to disorders such as cancer, lymphocyte depletion and atrophy or degeneration of tissues. ${ }^{16 ?}$

Two different forms of cell death can be distinguished: necrosis and apoptosis. Necrosis refers to a range of morphological changes resulting from the enzymatic digestion of the cell, the disruption of cellular membranes, and the denaturing of proteins that accompanies cell death. Necrosis is always accompanied by an inflammatory response (table 1.2). ${ }^{168,169}$

Apoptosis, in contrast, is a programmed, highly selective mechanism of cell death, which can be completed in several hours. Morphologically, the cell shrinks and the chromatim becomes pyknotic and condensed into sharply delineated masses present at the edge of the nuclear envelope. Simultaneously with these changes, cell volume decreases, cytoplasmic organelles compact, cell density increases, and DNA is tragmented. Microvill disappear, cytoplasmic blebs form at the cell surface, and portions of the cell bud to create apoptotic bodies. These apoptotic bodies may be phagocytized or remain free and undergo disinption by secondary necrosis. Apoptosis occurs without any signs of inflammation (table 1.2). 168,169

As described above, apoptosis is induced by a number of different stimuli, including DNA-damage, intracellular damage, growth factor withdrawal and cytokines. These stimuli operate in conjunction with other intrinsic factors that determine the cell's potential to undergo apoptosis. Cell type and basall conditions of the cell "including cell cycle and differentiation, markedly influence whether a cell will undergo apoptosis. Major regulators of apoplosis are indicated in table 1.3 and fig. 1.5. ${ }^{170.171}$ 
Table 1.2

Foatures of apoptosis and necrosis

\begin{tabular}{lll} 
& Apoptosis & Necrosis \\
\hline Morohology & Volume loss, chromatin & Increased volume, nucleus intact until \\
Plasma membrane & Remains intact & Early disruption \\
ONA breakage & Early, intranucleosomal pattern & Later, random DNA breakdown \\
Mechanisms of DNA & Gene activated, endonucleases & Random injury. ATP depleted \\
Tissue reaction & No inflammation, phagocytosis & Inflammatory response \\
Calcium & Moderate influx & Massive intux \\
\hline
\end{tabular}

Table 1.3

Some of the regulators of apoptosis

\begin{tabular}{ll}
\hline Apoptosis promotors & Apoptosis inhibitors \\
\hline Fas & Bci-2 \\
TNF receptor & Bcl-x \\
Caspases & Angiotensin I! \\
Bax & \\
Bad & \\
Bak & \\
Ceramide & \\
NO & \\
ANP & \\
Cholesterol oxides & \\
Angiotensin $\|$ & \\
\hline
\end{tabular}

Extracellular signals through the Fas receptor or TNF receptor, activation of TNF, IL1 and IFN $\gamma$, or intracellular signals related to p53 detection of irreparable DNAdamage lead to the activation of apoptatic genes. For example, Fas-induced apoptosis is mediated by the sphingomyelin pathway, which leads to ceramide accumulation, an important mediator of apoptosis (fig. 1.5). Other mediators. activated by the molecules described above, is the interleukin converting enzyme (ICE) family of proteases, also named the caspases. Activated caspases cleave specific proteins, activate the cell death pathway, and DNA-fragmentation occurs. ${ }^{170,171}$

The bcl-2 protein is a membrane associated protein of the mitochondria, nuclear envelope and endoplasmatic reticulum. The bci-2 family contains members that inhibit cell death (bcl-2 and bcl.x) and members that promote cell death (bax, bad. bak). Bcl-2 members associate as homodimers or heterodimers and the combined effects of the various dimers allow a fine level of control over cell turnover. When any of the death promotors exist as homo-or heterodimers, the cell dies by apoptosis. When a death promotor heterodimers with bcl-2 or bcl-x, cell death is prevented (fig. 1.5). ${ }^{170,171}$ 


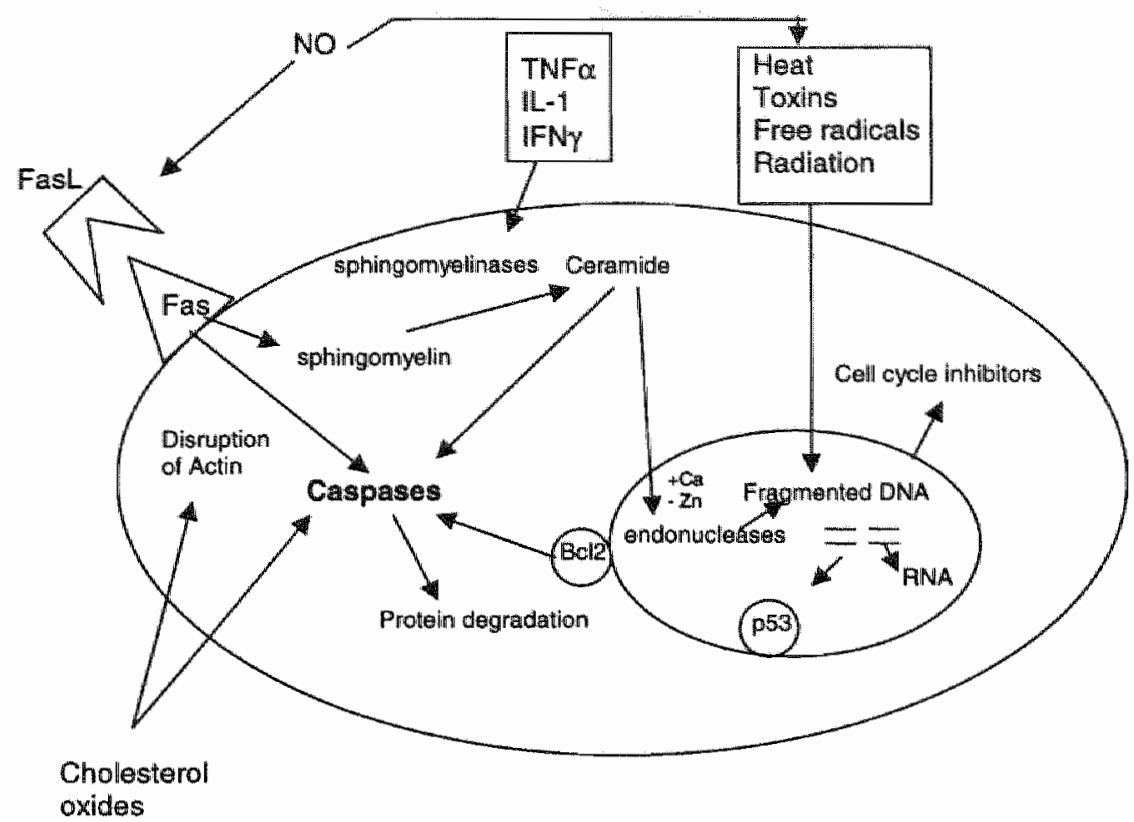

Fig. 1.5

Apoptosis: initiators and regulators

A shart overview

\subsection{Apoptosis and vascular disease}

\subsubsection{Apoptosis and arterial injury}

In addition to DNA-synthesis, apoptosis is an important feature of the response to arterial injury. It counteracts the excessive proliferative response of SMC in media and neointima.

\subsubsection{Apoptosis and animal models of arterial injury}

Cell death in the intima was already postulated by Clowes et al in 1983, on the basis of the number of replicating cells and the actual cell number in the intima ${ }^{90}$ Animal models of arterial injury following balloon angioplasty have shown that apoptosis occurs within 30 minutes after injury in medial SMCs, and remains elevated until 30 days after injury in SMCs in the intima. ${ }^{172.173}$ Levels of apoptosis after balloon injury vary from $3-20 \%$. Pro- and anti-apoptotic factors are also found in these models. For example, bcl-x, bcl-2, Fas, FasL, caspases, NO and p53 were present in neointimal lesions (table 1.4). ${ }^{174-179}$ Intervention studies in vivo are scarce, but show promising results (table 1.4). In this regard, administration of anti-sense oligonucleotides against the anti-apoptotic factor bcl-x induced selective apoptosis of neo-intimal cells and regression of neo-intimal thickening. ${ }^{178}$ Furthermore, delivery of FasL into 
the vessel wall induced apoptosis of Fas-expressing SMCs and inhibition of neointima formation. ${ }^{174,175}$

\subsubsection{Apoptosis and human neointima formation}

In human restenotic lesions, and saphenous vein grafts, increased levels of apoptosis are also present. ${ }^{170,180-183}$ Interestingly, apoptotic cells were found in areas adjacent to areas of DNA-synthesis, indicating that apoptosis is topographically related with DNA-synthesis. Apoptosis was predominantly observed in SMCs. Data regarding the presence of apoptotic markers, or intervention studies in human restenosis are scarce (table 1.4). ${ }^{176}$

\subsubsection{Apoptosis and primary atherosclerosis}

Cell death in human primary atherosclerotic lesions was already suggested by $R$. Virchow in $1858 .^{26}$ He stated that atherosclerotic lesions are formed by cell replication and then die. Since techniques have become available to visualize the apoptotic process, it is known that enhanced rates of apoptotic cell death are also found in human primary atherosclerotic lesions. ${ }^{172,180,184,185}$

\subsubsection{Apoptosis and animal models of primary atherosclerosis}

In hypercholesterolemic animal models of atherosclerosis, such as the rabbit and the ApoE-1- mouse, elevated levels of apoptosis were also abserved. ${ }^{145,186,187}$ Apoptotic nuclei were predominantly observed in macrophage derived foam cells, that were located at the medial site of the lesion. ${ }^{145,187}$

Genes related to the apoptotic process (p53, bax. Fas, NO) were present in atherosclerotic lesions of these models (table 1.4). ${ }^{170.171,188}$ in vivo intervention studies revealed divergent results. Overexpression of Fas ligand in hypercholesterolemic rabbits resulted in accelerated atherosclerotic lesion formation. ${ }^{189}$ On the contrary, the absence of p53 in ApoE-1- mice resulted in a decrease in lesion progression, but did not affect the level of apoptosis (table 1.4). ${ }^{153}$

\subsubsection{Apoptosis and human primary atherosclerosis}

in human atherosclerotic lesions, apoptotic labeling indices of $1-40 \%$ have been reported and apoptotic nuclei are mostly confined to macrophage derived foam cells in the lipid core and in regions adjacent to the lipid core ${ }^{172,190,484}$ or SMCs in the fibrous cap ${ }^{6,190,191 .}$

Expression of genes involved in apoptosis (like Fas, FasL, bol2, bax, caspases, $\mathrm{NO}$ ) is enhanced in atherosclerotic lesions, and the expression pattern varies at the different stages of atherosclerosis (table 1.4). ${ }^{170,171,184,192-195}$ Bax, a pro-apoptotic protein and bcl-2, an anti-apoptotic protein are both present in human fatty streak lesions, while no TUNEL positivity (an indicator of apoptotic cells) was observed. ${ }^{192}$ During lesion progression, expression of the pro-apoptotic proteins bax and ICE increases, while expression of the anti-apoptotic protein bol-2 is no longer observed. These phenomena are associated with an increased TUNEL-positivity. ${ }^{192}$ 


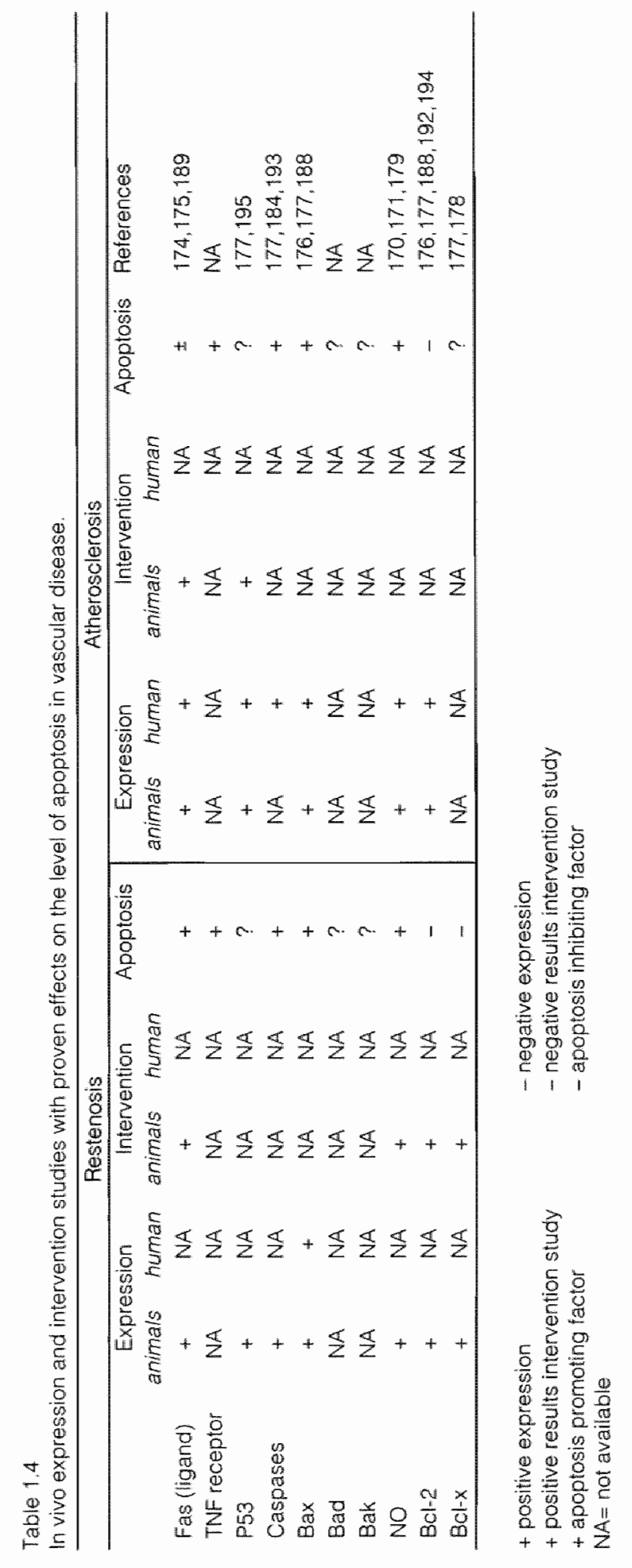


Intervention studies, directly targeting apoptotic genes in primary atherosclerosis in vivo are not available. Whether inhibition of apoptosis is beneficiall or detrimental during atherogenesis is still under debate. On the one hand, stimulation of apoptosis might reduce the extent of atherosclerosis. Furthermore, apoptosis of macrophages and T-lymphocytes might reduce inflammatory activify, and abolish their production of collagen degrading substances, thereby strengthening the fibrous cap. ${ }^{170.171}$ On the other hand, enhanced rates of apoptosis contribute to lipid core expansion and formation of an instable plaque configuration. 6,170,171,190,191 Furthermore, apoptosis of SMCs and fibroblasts in the fibrous cap may not only induce thinning of the fibrous cap, but also inhibit their collagen production, making the fibrous cap rupture prone. $6,7,170,171$ 
5. Atherosclerosis: an inflammatory disease

\subsection{Inflammation}

Inflammation is a reaction of the body that is characterized by the migration and extravasation of inflammatory cells from the blood into extravascular tissues, and is accompanied by activation of the immune system. Inflammation is frequently an expression of the host's attempt to localize and eliminate metabolically altered cells, foreign particles, or antigens. Under normal conditions, the inflammatory response eliminates the pathogenic insult and removes injured tissue components. This process accompanies either regeneration of the normal tissue architecture and return to physiologic function, or the formation of scar tissue to replace what cannot be repaired. ${ }^{196,197}$

The inflammatory response starts with the release of specific inflammatory mediators such as chemokines, cytokines, factors of the complement system, growth factors and vasoactive substances at the site of injury. These substances are able to recruit and guide inflammatory cells such as leukocytes, T-lymphocytes, monocytes and macrophages to the site of injury, make them remove injured tissue and induce a wound healing response (fig. 1.6).

The inflammatory reaction in general consists of several phases. First, vasoactive substances such as histamine induce vasodilation and increased vascular permeability, thereby facilitating influx of inflammatory mediators and cells. Furthermore, the expression of leukocyte adhesion molecules such as $P$ - and $E$ selectin, ICAM and VCAM is upregulated to allow increased rolling and adhesion of inflammatory cells to the endothelium, and finally diapedesis of inflammatory cells from the endothelium into the tissue (fig. 1.6). Subsequently, inflammatory cells migrate towards the site of injury by chemotaxis, elicited by chemokines (MCP-1, IL8), cytokines (IL1, TNF $\alpha$ ) and components of the complement system (C5a). When inflammatory cells arrive at the site of injury, macrophages remove damaged tissue by phagocytosis and initiate a reparative response. Activated macrophages and Tlymphocytes induce the expression of growth factors such as PDGF. FGF and TGF $\beta$. that induce proliferation and migration of (myo)fibroblasts and SMCs. These are able to synthesize collagen and other extracellular matrix elements, required for the induction of tissue fibrosis and the formation of scar tissue (fig. 1.6). ${ }^{196.197}$

There are two forms of inflammation that interrelate with another: acute and chronic inflammation. Acute inflammation comprises the initial response to injury and is characterized by the accumulation of fluid and plasma components in the affected tissue, stimulation of platelets and the presence of granulocytes. Chronic inflammation occurs as a result of ongoing injury. It is characterized by the presence of macrophages, T-lymphocytes and plasma cells, and a fibroproliferative response. Besides its positive effects, the inflammatory response is also potentially harmful to the body. For example, the acute inflammatory reaction for removal of a pathogen can result in high fever, diarrea, dehydration and death. Chronic inflammatory reactions can result in severe tissue dysfunction. Diseases that are the result of chronic inflammation include liver cirthosis, rheumatoid arthritis, glomerulosclerosis, pulmonary fibrosis and chronic pancreatitis. ${ }^{196.197}$ 


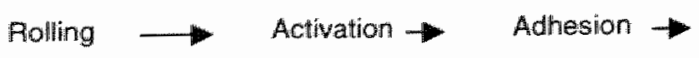

Selectins $(P, E, L)$

Fig. 1.6

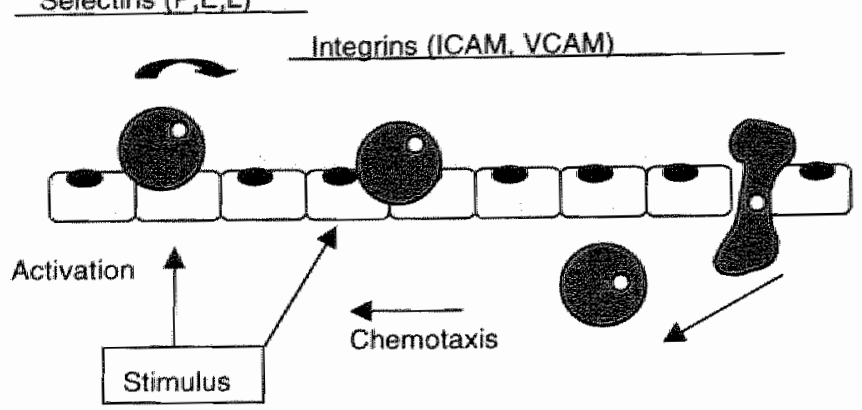

Leukocyte adhesion, diapedesis and migration during the early inllammatory response

\subsection{Key regulator of inflammation: CD4O-CD4OL system}

$\mathrm{CD} 40$ is a $50 \mathrm{kD}$ integral membrane protein of the tumor necrosis factor receptor (TNF-R) family of receptors that includes TNF-R1, TNF-R2, CD30, CD27, Fas and others, whose tissue distribution was originally thought to be restricted to B-cells, dendritic cells and basal epithelial cells. ${ }^{198}$ The ligand of CD 40, CD4OL (CD154, gp39, TBAM), is a $39 \mathrm{kD}$ member of the TNF family, and was originally thought to be restricted to activated T-lymphocytes. ${ }^{199}$ Similar to the TNFR-TNF binding, CD 40 forms a trimer that binds $\mathrm{CD} 4 \mathrm{OL}$ at the interface between two monomers. Each CD40 trimer is able to bind 1 CD $40 \mathrm{~L}$ molecule. After binding, the CD 40 associated factor (CRAF) associates with the cytoplasmatic tail of CD40, and signalling is elicited (fig. 1.7) ${ }^{200}$ Precise signalling mechanisms still remain to be elucidated.

The function of $\mathrm{CD} 40-\mathrm{CD} 40 \mathrm{~L}$ interactions was originally described to occur between $\mathrm{T}$ - and $\mathrm{B}$-lymphocytes, comprising Th-cell driven activation, proliferation and differentiation of B-lymphocytes, isotype switching, primary T-lymphocyte response and thymic selection. ${ }^{199,201}$

In vivo importance of CD40-CD4OL interactions, was found in patients suffering from the X-linked hyper-lgM syndrome. These patients show defective antibody production, since they lack normal B-cell proliferation and differentiation, and lack. circulating IgG and IgA, due to an absent isotype switching. Their symptoms are due to a dysfunctional CD4OL on activated T-lymphocytes, caused by a mutation in the extracellular domain of $\mathrm{CD} 40 \mathrm{~L},{ }^{202}$ Also mice with genetic disruption of the $\mathrm{CD} 4 \mathrm{O}$ CD4OL system show a defective immune-response. For example, CD4OL-f-mice cannot elicit an IgE inflammatory response to parasites, and fail to elicit eosinophilia after ovalbumin induced lung injury. ${ }^{203-206}$ 


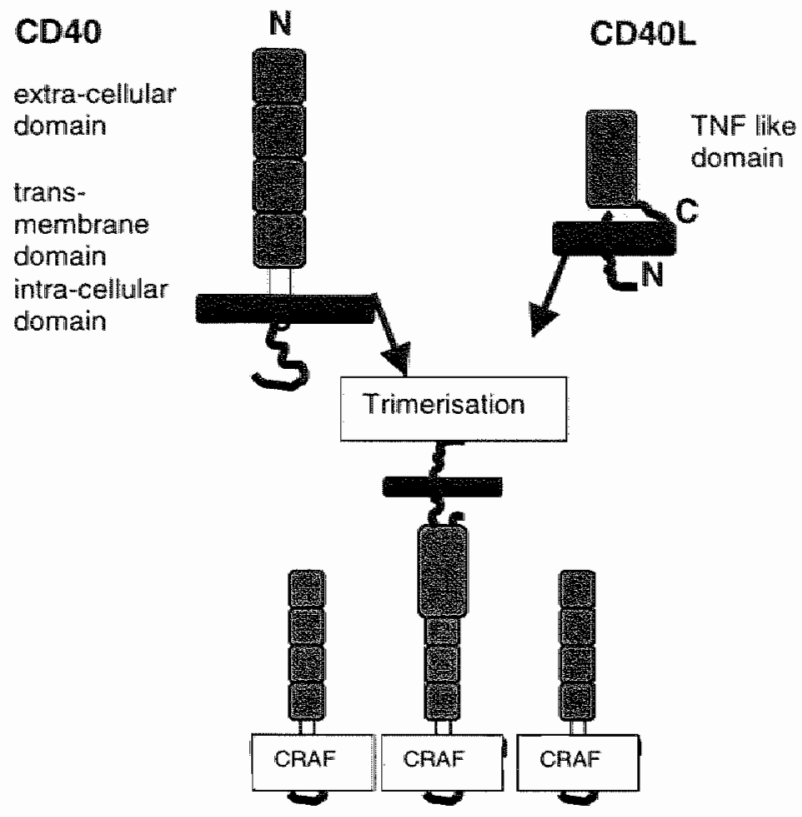

Fig. 1.7

\section{Signaling}

Structure of $\mathrm{CD} 40, \mathrm{CD} 4 \mathrm{OL}$ and their interactions

Nowadays, it is known that, except in T- and B-lymphocytes, CD40 and CD4OL are also expressed in other cell types, like dendritic cells, monocytes, macrophages, endothelial cells and fibroblasts. ${ }^{207-210}$ Furthermore, it was found that CD4O-CD4OL interactions are involved in many inflammatory pathways, like leukocyte-adhesion and migration, induction of chemokines, cytokines and activation of fibroblasts. $207-215$

CD40-CD4OL interactions are involved in a wide range of chronic inflammatory diseases, like allergic encephalitis, collagen induced arthritis, multiple sclerosis, SLE, Crohn's disease and in acute and chronic graft versus host disease. 202,216-218 Treatment with an anti-CD4OL antibody has shown promising results in animal models of these diseases. ${ }^{216.219-222}$ Blocking of CD.40 permitted long term acceptance of skin and cardiac allografts in mice 219.220 , and administration of an anti-CD4OL antibody prevented experimentally induced allergic encephalitis and collagen induced arthritis in mice. ${ }^{216,217}$ 


\subsection{Atherosclerosis and inflammation}

Table 1.5

Expression of inflammatory mediators in primary atherosclerosis

\begin{tabular}{|c|c|}
\hline Inflammatory mediators & References \\
\hline OXLDL & 231,232 \\
\hline \multicolumn{2}{|l|}{ Adhesion molecules } \\
\hline P-selectin & $233-235$ \\
\hline Euselectin & 234.235 \\
\hline ICAM & 233,235 \\
\hline VCAM & 236 \\
\hline \multicolumn{2}{|l|}{ Chemokines } \\
\hline MCP-1 & 237 \\
\hline CCA2 & 62 \\
\hline $11-8$ & 62 \\
\hline GRO- $a$ & 62 \\
\hline CXCR-2 & 62 \\
\hline \multicolumn{2}{|l|}{ Cytokines: } \\
\hline Gm-CSF & 238 \\
\hline IL-1 & 239.240 \\
\hline TNF $\alpha$ & 239,240 \\
\hline $\mathrm{IL}-6$ & 241,242 \\
\hline IFNy & 7 \\
\hline $1 L-10$ & 243,244 \\
\hline \multicolumn{2}{|l|}{ Proleases } \\
\hline MMP-1 & $245-248$ \\
\hline MMP-2 & $245-248$ \\
\hline$M M P-3$ & $245-248$ \\
\hline MMP-9 & $245-248$ \\
\hline TIMP & 248 \\
\hline
\end{tabular}

In addition to the chronic inflammatory diseases described above, atherosclerosis is also considered to be a chronic inflammatory disease. The latest modifications of the 'response to injury' hypothesis state that besides endothelial damage, activation of the endothelium and the subsequent upregulation of inflammatory pathways and the immune system, play a major role in the pathogenesis of atherosclerosis (see paragraph 2.2). ${ }^{33}$

Atherosclerotic lesions have long been considered to consist of an accumulation of lipids in the arterial wall, accompanied by SMC migration and proliferation. However, inflammatory cells and mediators are a major component of 
Table 1.6

Inflammatory mediators in atherosclerosis: Genetic interventions in mouse models of atherosclerosis.

\begin{tabular}{|c|c|c|c|}
\hline Inflammatory & Mouse model & Effects & References \\
\hline \multicolumn{4}{|c|}{ Adhesion molecules } \\
\hline P-selectin & P.sel-/W/ApoE-1- & $\downarrow$ plaque area & 249252 \\
\hline E-selectin & E-sell-/-/ApoE-/- & $\downarrow$ plaque area & $249-251$ \\
\hline ICAM & ICAM1-1-/APOE-1- & & 249,250 \\
\hline VCAM & Lethall & $\downarrow$ plaque area & \\
\hline \multicolumn{4}{|l|}{ Chemokines } \\
\hline MCP-1 & & $\begin{array}{l}\uparrow \text { plaque area, } \uparrow \text { lipid core, } \\
\uparrow \text { lesion progression }\end{array}$ & 253 \\
\hline & MCP-1-1-/APOE-1- & $\downarrow$ plaque area & 254 \\
\hline CCR2 & CCR-2-1-/APOE $-1-$ & $\downarrow$ plaque area, $\downarrow$ lesion & 255 \\
\hline $\mid \mathrm{L}-8$ & NA & & \\
\hline GRO- $\alpha$ & NA & & \\
\hline $\mathrm{C} \times \mathrm{CR} 2$ & CXCR-2-1-1LDLR-1- & $\begin{array}{l}\downarrow \text { plaque area, } \downarrow \text { lipid core, } \\
\downarrow \text { SMC proliferation }\end{array}$ & 62 \\
\hline \multicolumn{4}{|l|}{ Cytokines } \\
\hline \multirow[t]{2}{*}{$\mathrm{gm}-\mathrm{CSF}$} & Op-1-IApoE-1- & $\downarrow \downarrow \downarrow$ plaque area, & 52,256 \\
\hline & Op-1-MLLR-1- & $\begin{array}{l}\downarrow \downarrow \downarrow \text { plaque area, } \\
\downarrow \text { lesion progression }\end{array}$ & 257 \\
\hline IL-1 & NA & & \\
\hline TNFo & NA & & \\
\hline $\mathbb{H L}-6$ & IL-6 T/ApoE-1- & † plaque area & 258 \\
\hline IFNY & IFNy-/-/ApoE-1- & $\downarrow$ plaque area, $\uparrow$ collagen & 259,260 \\
\hline \multirow[t]{2}{*}{ IL-10 } & IL-10-/-IApoE-I- & $\begin{array}{l}\uparrow \text { plaque area, } \uparrow \text { T-lymphocytes, } \\
\Downarrow \text { collagen }\end{array}$ & 261,262 \\
\hline & IL-10 $1 / A p o E-/-$ & $\Downarrow$ plaque area & 261,262 \\
\hline \multicolumn{4}{|l|}{ Proteases } \\
\hline MMP-1 & NA & & \\
\hline MMP-2 & NA & & \\
\hline MMP-3. & NA & & \\
\hline MMP.9 & NA & & \\
\hline TIMP & TIMP-1 T/APOE-/ & $\downarrow$ plaque area, $\uparrow$ collagen, $\uparrow \mathrm{SMC}$ & 263 \\
\hline
\end{tabular}

the atherosclerotic lesion. Fatty streak lesions already contain a significant amount of activated macrophages and T-lymphocytes. ${ }^{223}$ During lesion progression, the inflammatory cell content even increases., ${ }^{43,39}$ Furthermore, all subsets of inflammatory mediators are expressed in atherosclerotic lesions (table 1.5) and their importance in atherosclerosis is confirmed by the effects on plaque development, progression and phenotype of genetic intervention studies in hyperlipidemic mice (table 1.6), thereby stressing the important role of inflammation during atherogenesis. Clinically, systemic inflammatory parameters, such as C-reactive protein, IL-6, fibrinogen, neopterin, SCD4OL, serum amyloid A and sVCAM are elevated in plasma of patients suffering from coronary or peripheral atherosclerosis ${ }^{224-227}$, while plasma levels of the anti-inflammatory factors, such as 
TGF $\beta$ and $L-10$, tended to be decreased in these patients. ${ }^{224,227.228}$ Furthermore, antibodies against pathogens like chlamydia trachomatis and CMV are also present in plasma and atherosclerotic plaques of patients suffering from vascular disease. ${ }^{140.229,230}$

\section{Inflammatory reactions in atherosclerosis}

Both modified LDL and oxLDL are able to induce the expression of several leukocyte adhesion molecules in vitro and in vivo. After activation of the endothelium, P- and E-selectin. ICAM-1 and VCAM-1 are upregulated, thereby inducing selective adhesion and transmigration of monocytes and T-lymphocytes into the intima (fig. 1.8). ${ }^{264-266}$ Subsequently, monocytes differentiate into tissue macrophages by stimulation with gm-CSF, start to ingest lipids, and become foam cells. $267-269$

Recent discoveries have provided insights into the process of lipid accumulation into macrophages, leading to foam cell formation. We now recognize a number of macrophage scavenger receptors that preferentially bind the atherogenic $0 \times L D L 270$ Internalization leads to the formation of lipid peroxides and facilitates the accumulation of cholesterol esters, resulting in foam cell formation. Scavenger receptors (SR) are divided into 6 classes, of which SRAl and 11, CD36 and CD68, are considered to be involved in atherogenesis. ${ }^{271}$ Besides cholesterol influx, efflux also occurs in foam cells. A protein known to be important in cholesterolwefflux is the cholesterol efflux regulatory protein ( $A B C$ ). Its importance in atherosclerosis is stressed by the observation that patients with mutations in the gene encoding this protein ( $\mathrm{ABC} 1$ gene) develop premature atherosclerosis (Tangier disease). ${ }^{272,273}$ Substances responsible for progression of atherosiclerotic lesions, are chemokines and cytokines. Chemokines (like MCP-1 and IL-8) and cytokines (like IL-1, TNF $\alpha$ and IFNy) are strong chemotactic agents and induce the expression of leukocyte adhesion molecules, thereby recruiting more macrophages into the lesion. ${ }^{274} 276$ Furthermore, chemokines and cytokines are able to activate intra-plaque macrophages and T-lymphocytes, thereby augmenting the inflammatory response. $239,240,274-276$ Activated plaque macrophages and T-lymphocytes exert a spectrum of pro-atherogenic actions, including scavenging and oxidizing $L D L$, induction of the expression of leukocyte adhesion molecules, induction of other chemokines and cylokines, proteolytic enzymes, growth factors, apoptosis and procoagulant molecules like tissue factor (fig. 1.8), 7,33

Growth factors (TGFB, PDGF, FGF) $31,277-279$, proteolytic enzymes (MMP-1,-2,-3 and 9$)^{245-248}$ and their inhibitors $(T I M P-1,-2,-3)^{248}$, that can be induced by inflammation, are important regulators of collagen turnover during atherosclerosis. Growth factors induce the migration and proliferation of SMCs and (myo)fibroblasts into the atherosclerotic lesion. In addition to proliferation and migration, growth factors (especially TGF and PDGF $63.280-282$ ) also induce SMCs/fibroblasts to synthesize extracellular matrix. For example, TGFB induces the expression of fibronectin, collagen types II. III, IV and $V$, as well as glycosaminoglycans, proteoglycans and elastic fiber proteins. ${ }^{283}$ IFNy inhibits collagen synthesis, 
oxLDL
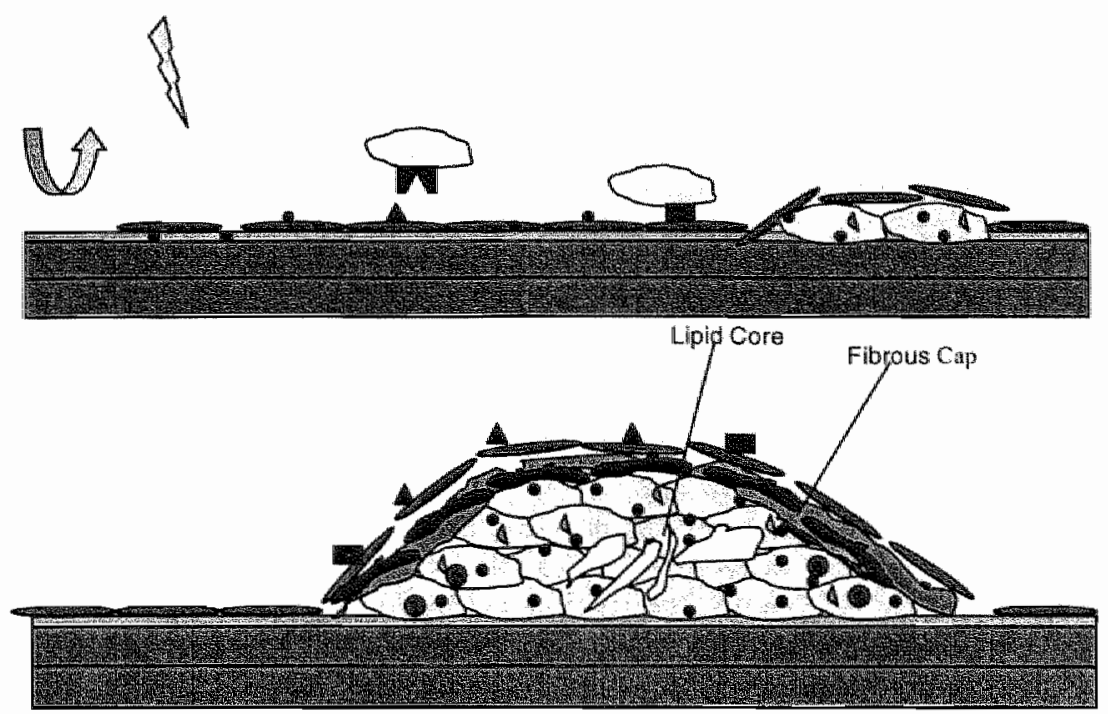

\begin{tabular}{|c|c|c|c|}
\hline 0 & Shear sitress & & Monocyte \\
\hline & Endothelial cell & & Foam cell \\
\hline - & OXLDL & 4 & Scavenger raceptor \\
\hline 4 & Selectins & . & T-tymphacytes \\
\hline$=$ & Integrins & & SMC \\
\hline
\end{tabular}

Fig. 1.8

Inflammation during atherogenesis. The upper panel shows the inflammatory response and mediators during lesion initiation. The lower panel shows a rolle of these mediators in plaque progression.

members of the matrix-metalloproteinase family degrade collagen, and tissue inhibitors of matrix metalloproteinases (TIMPS) prevent degradation.

When inflammation procedes, the balance between macrophage accumulation, collagen synthesis and degradation becomes disturbed. Procoagulant factors like tissue factor are formed in excess, the fibrous cap weakens, the lipid core expands, and the atherosclerotic lesion can rupture, and progress into a clinically significant slage. ${ }^{7}$

\subsection{CD40-CD40L system in atherosclerosis}

Until now, a key regulator of the inflammatory events during atherogenesis has not been defined. However, as described above, CD40-CD40L interactions are known 
to be a key modulator of many inflammatory and immune reactions. Therefore, a role for CD40-CD40L interactions in atherosclerosis is proposed.

Increasing evidence suggests a role for CD40-CD4OL signaling in atherosclerosis. Immunohistochemistry and in situ hybridization on advanced human atherosclerotic plaques revealed the presence of CD40 and CD4OL in plaque macrophages, endothelial cells, T-lymphocytes and SMCs. Both CD $40 \mathrm{OL}$ and CD40 were predominantly present at the shoulder region. ${ }^{284}$ Furthermore, sCD4OL was present in patients suffering from unstable angina. ${ }^{225}$ Interestingly, hyperlipidemic mice, containing initial atherosclerotic lesions that were treated with an anti-CD40L antibody for $12 \mathrm{wks}$, exhibited a profound reduction in atherosclerotic lesion area. ${ }^{285}$

\subsubsection{Possible effects of CD4O-CD4OL interactions in atherosclerosis Leukocyte adhesion molecules}

As described above, in table 1.6 and fig. 1.8, leukocyte adhesion molecules like Pand E-selectin, ICAM and VCAM are crucial for the development and progression of atherosclerosis. ${ }^{33}$ Activation of the CD40-CD4OL pathway in vitro stimulates the expression of E-selectin, VCAM and ICAM in endothelial cells and monocytes $209,211,215$ and the expression of ICAM and VCAM in fibroblasts. ${ }^{209,210}$ Interestingly, hyperlipidemic mice, expressing initial atherosclerotic lesions show a decreased expression of VCAM after anti-CD4OL antibody treatment. ${ }^{285}$

\section{Chemokines}

Chemokines include more than 30 homologous small polypeptides, that all have a role in the recruitment of leukocytes, and the migration, growth and activation of multiple cell types in inflammatory states including atherosclerosis (table 1.5 and 1.6). ${ }^{274}$ Activation of the CD40-CD4OL system seems crucial for the expression of chemokines. For example, in vitro cell-cell contact between macrophages and cells engineered to express CD4OL induce macrophages to express MCP-1, MIP-1 $\alpha$, MIP-1 $\beta$ and RANTES. ${ }^{208}$ Furthermore, platelet CD4OL can induce HUVEC cells to express both MCP-1 and $\mid \mathrm{L}-8$, all chemokines known to be involved in atherosclerotic lesion progression and initiation (table 1.5 and 1.6). ${ }^{286}$

\section{Cytokines}

Cytokines that are involved in atherosclerotic lesion progression, are also expressed after stimulation of the CD40-CD4OL pathway. In SMCs and endothelial cells, stimulation induces the pro-atherogenic cytokines $I L-1 \beta, I C E$, and IL-6, but not TNF $\alpha{ }^{209,211,212,214,284}$ However, in macrophages, CD40 ligation induces the cytokines IL-1 $\beta, 1 L-6, I L-12$ as well as TNF $\alpha,{ }^{207,215,284}$ Furthermore, CD40 ligation on fibroblasts induces production of IL-6. ${ }^{210}$

\section{Matrix metalloproteinases}

CD40 ligation on human endothelial cells, SMCs and macrophages induces the expression and release of MMP-1 and MMP-3 from all three cell types, as well as MMP-9 from endothelial and SMCs. ${ }^{287.288}$ Moreover, MMP-2, present in endothelial 
cells and SMCs in its latent form, is released in its activated form afier CD40 ligation. ${ }^{287,289}$ CD40 ligation induces the expression of these enzymes to a greater extent than maximally-effective concentrations of TNF $\alpha$ or $1 L-1 \beta$, established agonists of MMPs. ${ }^{287}$

\section{CD40.CD40L interactions and plaque rupture}

CD40-CD40L interactions are also postulated to play an important role in the development of plaque rupture. Not only are CD40 and CD40L abundantly present in the shoulder region of rupture prone lesions ${ }^{284}$, but stimulation of their signaling pathway also results in the upregulation of the expression of MMP-1, $-2,-3$ and -9 287,288 and the procoagulant tissue factor in vitro. ${ }^{288,290}$ Furthermore, both activated platelets and fresh thrombi express high levels of CD40L. ${ }^{291}$ Patients suffering from unstable angina show elevated levels of degranulated platelets and SCD4OL plasma levels. 225 Therefore, CD40L-CD40 signaling may induce a procoagulant stage, a feature favoring the development of plaque ruplure and thrombosis. ${ }^{292}$

\section{Hypothesis}

As discussed in the previous paragraphs, atherosclerosis is a multifactorial disease, and two of its main mechanisms, important in its pathogenesis, are thought to be changes in cell turnover (DNA-synthesis and apoptosis) and chronic inflammation.

It is known that both DNA-synthesis and apoptosis are present in atherosclerotic plaques, and it is postulated that enhanced levels of apoptosis contribute to the development of an unstable atherosclerolic lesion. Cells reported to exhibit DNAsynthesis and apoptosis are the macrophage and the SMC. However, levels of DNA-synthesis and apoptosis in the different stages of plaque progression, as well as their topographical distribution, and cell-phenotype are largely unknown, since most of the work on cell turnover is focussed on advanced atherosclerotic llesions, and/or has used atherectomy specimens. In these small samples of atheromatous tissue, plaque morphology has been disrupted, and the precise location of DNAsynthesizing and apoptotic cells is difficult to determine.

Our first working hypothesis is that the level, fopographical distribution and phenotype of DNA-synthesizing and apoptotic cells change during atherogenesis. We hypothesized that DNA-synthesis is confined to the SMC, and that its level is higher in early lesions than in advanced atherosclerotic lesions. Furthermore, we hypothesize that apoptosis occurs in SMCs and macrophages, and that it is an important feature of advanced atherosclerotic lesions. Subsequently, we hypothesize that genetic absence of Gas6, known as a survival factor suppresses DNA-synthesis and promotes apoptosis, thereby resulting in smaller atherosclerotic lesions in ApoE-l- mice.

The second main mechanism, important during atherogenesis, is the upregulation of inflammatory pathways. The key regulator of inflammation during atherogenesis is not known, although increasing evidence suggests a role for the CD40-CD40L system. Our second working hypothesis was that the CD40-CD4OL system is a key regulator of the inflammatory pathways during atherogenesis. 
Inhibition of CD40-CD4OL signaling will therefore inhibit lesion initiation and lesion progression.

\section{This thesis}

In this thesis, we first characterized plaque phenotype and the diet dependent progression of atherosclerosis in ApoE*3Leiden mice (chapter 2). Subsequently, the level, distribution-pattern and cell phenotypes of DNA-synthesis and apoptosis of all stages of atherosclerosis of mice and man are described in chapters 2 and 3 . To further characterize ApoE*3Leiden and ApoE-f- mice, we investigated the degree of vascular remodeling during in different stages of atherosclerosis (chapter 4). Chapter 5 describes the effect of genetic absence of Gas6 on cell turnover and plaque phenotype in ApoE-l-mice.

This brings us to the second hypothesis. Chapters 6 and 7 focus on the CD40CD4OL system. In chapter 6 , the role of complete genetic disruption of CD4OL on plaque progression and phenotype is described, while chapter 7 focusses on the effects of early and delayed anti-CD $40 \mathrm{OL}$ antibody treatment. In chapter 8 , the findings of these studies and future directions are discussed.

\section{References}

1. Stary HC, Blankenhorn DH, Chandler $A B$, Glagov $S$, Insull W Jr, Richardson M. Rosenfeld ME, Schaffer SA, Schwartz CJ. Wagner WD, et al: A definition of the intima of human arteries and of its atherosclerosis-prone regions. A report from the Committee on Vascular Lesions of the Council on Arterlosclerosis, American Heart Association. Circulation 1992;85:391-405.

2. Stary $\mathrm{HC}$ : Evolution and progression of atherosclerotic lesions in coronary arteries of children and young aduits. Arteriosclerosis 1989;9:19-131.

3. Stary HC: Macrophage foam cells in the coronary artery intima of human infants. Ann N Y ACad Sol $1985 ; 454: 5-8$.

4. Stary HC, Chandler $A B$, Dinsmore RE, Fusiter V. Glagov S, Insull W Jr, Rosenfeld ME, Schwartz CJ, Wagner WD. Wissler RW: A definition of advanced types of atherosclerotic lesions and a histological classification of atherosclerosis. A report from the Committee on Vascular Lesions of the Council on Arteriosclerosis, American Heart Association. Arterioscler Thromb Vasc Bio $1995 ; 15: 1512-1531$

5. Davies MJ: Acute coronary thrombosis-the role of plaque disruption and its initiation and prevention. Eur Heart / 1995; 16 Suppl L.3-7.

6. Lee RT, Libby P. The unstable atheroma. Arterioscler Thromb Vasc Biol 1997:47:1859-1866.

7. Libby P: Molecular bases of the acute coronary syndromes. Circulation 1995;91:2844-2850.

8. Fuster V: Lewis A. Conner memorial lecture. Mechanisms leading to myocardial infarction: insights from studies of vascular biology. Circulation 1994;90:2126-2146.

9. Glasser SP. Selwyn AP. Ganz P. Atherosclerosis: risk factors and the vascular endothelium. Am Heant $J$ 1996; 131:379-384.

10. Nygard $O$. Nordrehaug JE, Refsum H. Ueland $P M$, Farstad M, Voliset SE: Plasma homocysteine levels and mortality in patients with coronary heart disease. N Engl J Med 1997;337:230-236.

11. Jensen T, Bjerre-Knudsen J. Feldt-Rasmussen B. Deckert T. Features of endothelial dysfunction in early diabetic nephropathy. Lancel 1989:4:461-463.

12. Krilchevsky D. Diet and atherosclerosis. Am Heant J 1999; 138:S426-S429

13. Hambrecht $A$, Wolf A, Gielen S, Linke A, Hofer J. Erbs S. Schoene N, Schuler G: Effect of exercise on coronary endothelial function in patients with coronary antery disease. $N$ Engi $I$ Med
$2000 ; 342: 454-460$. 
14. Berenson GS, Srinivasan SR, Bao W, Newman WP. Tracy RE, Wattigney WA: Association between multiple cardiovascular risk factors and atherosclerasis in children and young adults. $N$ Engt Med 1998;338:1650-1656.

15. Berliner JA, Navab M, Fogelman AM, Frank JS, Demer LL, Edwards PA. Watson AD. Lusis Ad: Atherosiclerosis: basic mechanisms. Oxidation. inflammation, and genetics. Circulation $1995 ; 91: 2488-2496$.

16. Ip JH, Fuster V, Badimon L. Badimon J. Taubman MB, Chesebro JH: Syndromes of accelerated atherosclerosis: Role of vascular injury and smooth muscle cell prolteration. I Am Coll Cardiol 1990; 15:1667-1687.

17. Gaziano JM: When should heart disease prevention begin? N Eng J Med 1998;338: 1690-1692.

18. Amsterdam EA, Hyson D, Kappagoda CT: Nonpharmacologic therapy for coronary artery atherosclerosis:results of primary and secondary prevention trials. Am Hear $J$ 1994:128:13441352

19. Durrington $P N$, Prais $H_{n}$ Bhatnagar D. France $M_{6}$ Crowley $V$, Khan J, Morgan J: Indications for cholesterollowering medication: comparison of risk assessment methods. Lancet 1999,353:278281.

20. Scandinavian Simvastatin Survival Study Group: Randomized trial of cholesterol lowering in 4444 patients with coronary heart disease: the Scandinavian Simvastatin Survival study. Lancet $1994 ; 344: 1383-1389$.

21. Shepherd J, Cobbe SM, Ford I, isles CG, Lorimer AR, Maciarlane PW, MCKillop JH, Packard CJ: Prevention of coronary heart disease with pravastatin in men with mypercholesterolemia. N Engl d Med' 1995; 16:1301-1307.

22. The Heart Outcomes Prevention Evaluation Study Investigators: Vitamin E supplementation and cardiovascular events in high risk patients. N Engl J Med 2000;342:154-160.

23. Diaz MN. Frei B, Vita JA, Keaney JF: Anti-oxidants and atherosclerotic heart disease. N Engt J Med 1997;337:408-416.

24. Stephens NG. Parsons A, Schofield PM, Kelly F, Cheeseman K, Mitchinson MJ, Brown M: Randomised controlled trial of vitamin $E$ in patients with coronary disease: Cambridge Hieart Antioxidant Study (CHAOS). Lancet 1996;347:781-786.

25. The Heart Outcomes Prevention Evaluation Investigators: Effects of an angiolensin-convertingenzyme inhibitor, ramipril, on cardiovascular events in high-risk patients. $N$ Engl I Med 2000;342:145-153.

26. Virchow $R$ : Cellular Pathology as based upon physiological and pathological histology. Classics of medicine library. Birmingham, Alabama, 1858.

27. Osler W (ed): Diseases of the arteries. Philadelphia, Lea and Febiger, 1908.

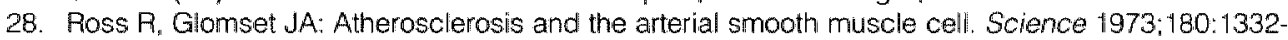
1339 .

29. Ross R, Glomset J, Harker L: Response to injury and atherogenesis. Am J Pathol 1977;86:675-684.

30. Stemerman MB. Ross R: Experimental arteriosclerosis. I. Fibrous plaque formation in primates, an electron microscope study. J Exp Med 1972;136:769-789.

31. Ross R: The pathogenesis of atherosclerosis: a perspective for the 1990s. Nature 1993;362:801. 809.

32. Ross R: Cell biology of atherosclerosis. Annu Rev Physiol 1995;57:791-804.

33. Ross R: Atherosclerosis. An inflammatory disease. N Engl J Med 1999;340:115-126.

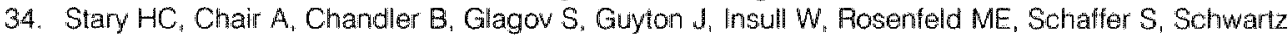
CJ. Wagner WD. Wissler RW: A definition of initial. fatty streak, and intermediate lesions of atherosclerosis. A report from the committee on vascular lesions of the council on arteriosclerosis. American Heart Association. Arterioscler Thromb Vasc Biol 1994:14:840.856.

35. Virmani R, Kolodgie FD, Burke AP. Farb A, Schwartz SM: Lessons from sudden coronary death. A comprehensive morphological classification scheme for atherosclerotic lesions. Arterioscler Thromb Vasc Biol 2000;20:1262-1275.

36. Stary HC: Natural history and histological classification of atherosclerotic lesions. An update. Arterioscler Thromb Vasc Biol 2000,20:1177-1178.

37. Katsuda $S$, Boyd HC, Fligner $C$, Ross $R$, Gown AM: Human atherosclerosis. III Immunocytochemical analysis of the cell composition of lesions of young adults. Anry of Pathol $1992 ; 140: 907-914$. 
38. Gown AM, Tsukada T. Ross R: Human atherosclerosis II. Immunocytochemical analysis of the cellular composition of human atherosclerotic lesions. Am J Pathol 1986;125:191-207.

39. van der Wal $A$, Becker $A E$, van der Loos CM. Das PK: Site of intimal rupture or erosion of thrombosed coronary atherosclerotic plaques is characterized by an inflammatory process irrespective of dominant plaque morphology. Chrculation 1994,89:36-44.

40. Gotlieb Al, Langille BL: The role of theology in atherosclerotic coronary artery disease, in Fuster $\mathrm{V}$, Ross $R$, Topol EJ (eds): Atherosclerosis and coronary artery disease, 1 st ed. Philadelphia, Lippincott-Raven, 1996, vol 1. pp. 595-606.

41. Nakashima Y. Plump AS, Raines EW, Breslow JL, Ross R: ApoE-deficient mice develop lesions of all phases of atherosclerosis throughout the arterial tree. Arterioscter Thromb 1994:14:133-140.

42. Masuda J. Ross R: Atherogenesis during low-level hypercholesterolemia in the nonhuman primate, 1: fatty streak formation. Arteriosclerosis 1990; 10:164-177.

43. Wagner WD. Clarkson TB, Feldner MA. Prichard RW: The development of pigeon strains with selected atherosclerosis charackeristics. Exp Mol Path 1973;19:304-319.

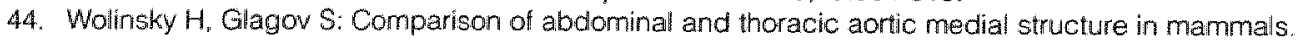
Circ Res 1969;15:677-686.

45. Clark JM, Glagov S: Structural integration of the arterial wall. I. Relationships and attachments of medial smooth muscle cells in normally distended and hyperdistended aortas. Lab Invest $1979 ; 40: 587-602$.

46. Stary HC: The sequence of cell and matrix changes in atherosclerotic lesions of coronary arteries in the first forty years of life. Eur Heart $11990 ; 11$ (suppl.E); 3-19.

47. Glagov S, Weisenberg E, Zarins CK, Stankunavicius R, Kolettis GJ: Compensatory enlargement of human atherosclerotic coronary arteries. N Engl J Med 1987;316:1371-1375.

48. Pasterkamp G. Wensing PJW. Post MJ "Hillen B, Mali WPTM, Borst C: Paradoxical arterial wall shrinkage may contribute to luminal narrowing of human atherosclerotic femoral arteries. Circulation 1995;91:1444-1449.

49. Pasterkamp $G$, Borst $C$, Post $M$. Mall WPTM. Wensing PJW. Gussenhoven EJ. Hillen $B$ : Atherosclerotic arterial remadeling in the superficial femoral artery. Individual variation in local compensatory enlargement response. Circulation 1996,93:1818-1825.

50. Pasterkamp G, de Kleijn DPV, Borst C. Arteriall remodeling in atherosclerosis, restenosis and after alteration of blood flow: patential rnechanisms and clinical implications. Cardiovasc Res 2000:45:843-852.

511. Kiechl S. Willeit J: The natural course of atherosclerosis. Part Il: Vascular remodeling. Avterioscler Thromb Vasc Biol 1999:19:1491-1498.

52. de Villiers WUS. Smith JD, Miyata M. Dansky HM, Darley E, Gordon S: Macrophage phenotype in mice deficient in both macrophage-colony-stimulating factor (Op) and apolipoprotein $E$. Arterioscler Thromb Vase Biol 1998:18:631-640.

53. Mintz GS, Kent KM, Pichard AD, Satler LF. Popma JU, Leon MB: Contribution of inadequate arterial remodeling to the development of focal coronary artery stenoses. An intravascular ultrasound study. Circutation 1997:95:1791-1798.

54. Nishioka T, Luo $H$, Eigler NL. Berglund H, Kim CJ. Siegel RJ: Contribution of inadequate compensatory enlargement to development of human coronary arlery stenosis: an in vivo inturavascullar ultrasound study. J Am Coll Cardiol 1996;27:1571-1576.

55. Pasterkamp G. Schoneveld AH, van der Wal A. Haudenschild C, Clarijs R.JG, Becker AE, Hillen B. Borst $\mathrm{C}$ : Relation of arterial geometry to luminall narrowing and histologic markers for plaque vulnerability: the remodeling paradox. J Am Coll Cardiol 1998;32:655-662. 56. Shah PK: Plaque size, vessel size and plaque vulnerability: bigger may not be better. I Am Coll
Cardiol 1998:32:663-664.

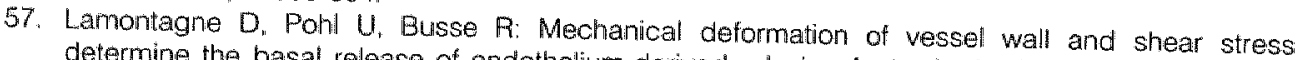
determine the basal release of endothelium-derived relaxing factor in the intact rabbit coronary vascular bed. Circ Res 1992; 70:123.

58. Hodgson J. Marshall J: Direct vasoconstriction and endothelium-dependent vasodilation. Mechanisms of acetylcholine effects on coronary flow and arterial diameter in patients with non-
stenotic coronary arteries. Circulation 1989;79:1043-1051.

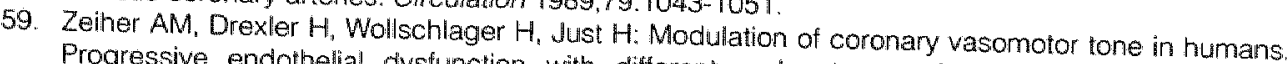
Progressive endothelial dysfunction with different early stages of coronary atherosclerosis. 
60. Vita JA, Treasure $C_{3}$, Ganz $P$, Cox DA, Fish RD. Selwyn AP: Control of shear stress in the epicardial coronary arteries of humans: impaiment by atherosclerosis. I Am Coll Cardiol $1989 ; 14: 1193-1199$.

61. Cox DA, Vita JA, Treasure CB, Fish RD. Alexander RW. Ganz P. Selwyn AP: Atherosclerosis impairs flow-mediated dilation of coronary arteries in humans. Croulation $1989 ; 80: 458-465$.

62. Boisvert WA, Santiago $R$, Curtiss LK, Terkeltaub RA: A Leukocyte homologue of the ll-B receptor CXCR-2 mediates the accumulation of macrophages in aherosclerotic lesions of LDL receptordeficient mice. I Clin Invest 1998; 101:353-363.

63. Kamiya A. Togawa T: Adaptiwe regulation of wall shear stress to flow change in the canine carotid antery. Am J Physiol 1980;239: H14-H21.

64. Mulvany MJ: Determinants of vascular structure. J Cardfovasc Pharmacol 1992;19:S1-S6

65. Crawford T, Levene Cl: Medial thinning in atheroma. J Pathol 1953;66:19-23.

66. Carmeliet $P_{n}$ Moons L, Lijnen R, Baes M, Lemaitre V, Tipping P. Drew A, Eeckhout $Y$. Shapiro $S$. Lupu $F$, Collen $D$ : Urokinase-generated plasmin activates matrix metalloproteinases during aneurysm formation. Nat Gen 1997:17:439-444.

67. Anidjar S, Kieffer E: Pathogenesis of acquired aneurysms of the abdominal aorta. Ann Vasc Surg $1992 ; 6: 298-305$

68. Armstrong ML, Heistad DD. Marcus ML. Megan MB, Piegors D.J: Structural and hemodynamic responses of peripheral arteries of Macaque monkeys to atherogenic diet. Arteriosclerosis $1985 ; 5: 336-346$.

69. Clarkson TB, Prichard RW, Morgan TM, Petrick GS. Klein KP: Remodeling of coronary arteries in human and nonhuman primates. JAMA 1994;271.289-294.

70. Kakuta T, Currier لWW. Haudenschild CC, Ryan TJ, Faxon DP: Differences in compensatory vessel enlargement, not intimal formation, account for restenosis aiter angioplasty in the hypercholesterolemic rabbit model. Circulation 1994;89:2809-2815

71. Post MJ, Borst C. Kuntz RE: The relative importance of arterial remodeling compared with intimal hyperplasia in lumen renarrowing after balloon angioplasty. Circulation 1994;89-2816-2821.

72. Bayer IM, Adamson SL. Langille L: Atrophic remodeling of the artery-cuffed artery. Arterioscler Thromb Vasc Biol 1999; 19:1499-1505.

73. Seo HS, Lombardi DM, Polinski P. Powel-Braxton L, Bunting S, Schwartz SM, Rosenfeld ME: Peripheral vascular stenosis in apolipoprotein E-deficient mice. Potential roles of lipid deposition. medial atrophy, and adventitial inflammation. Arterioscler Thromb Vasc Biol 1997:17:3593-3601.

74. Masulda J, Ross R: Atherogenesis during low-level hypercholesterolemia in the non-human primate, Il: fatty streak conversion to fibrous plaque. Arteriosclerosis 1990;10:178-187,

75. Gerrity RG: The role of the monocyte in atherogenesis, I: transition of blood-borne monocytes into foam cells in fatty lesions. Am J Pathol 1981:103:18 $1-190$.

76. Reitman JS, Mahley RW, Fry DL: Yucatan miniature swine as a model for diet-induced atherosclerosis. Atherosclerosis 1982;43:119-132

77. Rosenteld ME. Tsukada T. Gown AM. Ross R: Fatty streak initiation in Watanabe heritable hyperlipidemic and comparably hypercholesterolemic fat-fed rabbits. Arteriosclerosis 1987:7:9-23.

78. Rosenfeld ME, Tsukada $T$, Chait A, Bierman EL, Gown AM. Foss R: Fatty streak expansion and maturation in Watanabe heritable hyperlipidemic and comparably hypercholesterolemic fat-fed rabbits. Anterioscterosis 1987:7:24-34.

79. Sima A, Bulla $A$, Simionescu $N$ : Experimental obstructive cononary atherosclerosis in the hyperlipidemic hamster. I Submicrosc Cytol Pathol 1990,22:1-16.

80. Clowes AW. Reidy MA. Clowes MM: Mechanisms of stenosis after arterial injury. Lab Invest 1983;49:208-215.

81. Clowes AW. Breslow JL, Kannovsky MU: Regression of myointimal thickening following carotid endothelial injury and development of aortic toam cell lesions in long term hypercholesterolemic rats. Lab invest 1977,36:73.

82. Paigen $B$, Ishicla $B Y$, Verstuyft $J$, Winters $A B$, Albee D: Atherosclerosis susceptibility differences among progenitors of recombinant inbred strains of mice. Arteriosclerosis 1990;10:316-323.

83. Mehrabian M, Demer LL, Lusis AJ: Differential accumulation of intimal monocytes-macrophages relative to lipoproteins and lipoluscin corresponds to hemodynamic forces on cardiac valves in mice. Arterioscler Thromb 1991;11:947-957. 
84. Plump AS, Smith JD. Hayek T. Aalto-Setala K, Walsh A, Verstuyft JG, Rubin EM, Breslow JL: Severe hypercholesterolemia and atherosclerosis in apolipoprotein E-deficient mice created by homologous recombination in ES cells. Cell 1992:71:343-353.

85. Zhang SH, Reddick FiL, Piedrahita JA, Maeda N: Spontaneous hypercholesterolemia and arterial lesions in mice lacking apolipoprotein E. Science 1992:258:468-471.

86. Ishibashi S, Brown MS, Goldstein JL, Gerard RD, Hammer RE. Herz J: Hypercholesterolemia in low density lipoprotein receptor knockout mice and its reversal by adenovirus-mediated gene delivery. $J$ Clin Invest 1993;92:883-893.

87. de Knijff $P$, van den Maagdenberg AM, Stalenhoef AF, Leuven $\downarrow A$, Demacker PN, Kuyt LP, Frants RR, Havekes LM: Familial dysbetalipoproteinemia associated with apolipoprotein E3-Leiden in an extended multigeneration pedigree. J Clin Invest 1991;88:643-655.

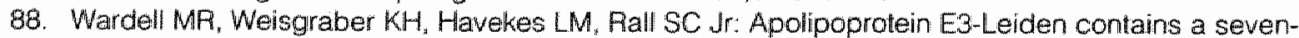
amino acid insertion that is a tandem repeat of residues 121-127. I Biol Chem 1989:264:2120521210.

89. van den Maagdenberg AMJM, de Knijff $P$, Stalenhoef AFH, Gevers Leuven JA, Havekes LM. Frants RR: Apolipoprotein E*3-Leiden allele results from a partial gene duplication in exon 4. Biochem Biophys Res Commun 1989:165:851-857.

90. van Vilimen BJ, van den Maagdenberg AM, Gijbels MJ, van der Boom H. HogenEsch H. Frants RR, Hofker MH, Havekes LM: Diet-induced hyperlipoproteinemia and atherosclerosis in apolipoprotein E3-Leiden transgenic mice. J Clin Invest 1994;93:1403-1410.

91. van den Maagdenberg AM, Hofker MH, Krimpenfort PJ. de Bruijn 11 , van Vlijmen $B$, van der Boom H. Havekes LM, Frants RP: Transgenic mice carrying the apolipoprotein E3-Leiden gene exhibit hyperlipoproteinemia. J Biol Chem 1993;268:10540-10545.

92. Giroot PH, van Vlijmen BJ, Benson GM, Hofker MH, Schiffelers R, Vidgeon Hart M. Havekes LM: Quantitative assessment of aortic atherosclerosis in APOE $^{\star} 3$ Leiden transgenic mice and its relationship to serum cholesterol exposure. Arterioscler Thromb Vasc Brol 1996:16:926-933.

93. Li JM, Brooks G: Cell cycle regulatory malecules (cyclins, cyclin-dependent kinases and cyclin dependent kinase inhibitors) and the cardiovascular system. Potential targets for therapy? Eur Heart $11999: 20: 406-420$.

94. Schwartz SM, Ross R: Cellular proliferation in atherosclerosis and hypertension. Prog card dis $1984 ; 16: 355-372$

95. Clowes AW, Reidy MA, Clowes MM: Kinetics of cellular proliferation afier anterial injury. I. Smooth muscle growth in the absence of endothelium. Lab invest 1983;49:327-333.

96. Clowes AW, Clowes MM, Fingerle J, Reidy MA: Regulation of smooth muscle cell growth in injured artery. J Cardiovasc Pharmacol 1989:14:S12-S15.

97. Hanke H, Strohschneider T, Oberholf M. Betz E, Karsch K: Time course of smooth muscle cell proliferation in the intima and media of arteries following experimental angioplasty. Circ Res 1990:67:651-659.

98. Clowes AW. Clowes MM. Reidy MA: Kinetics of cellular proliferation after arterial injury. III. Endothelial and smooth muscle growth in chronically denuded vessels. Lab invest 1986,54:295.
303 .

99. Schwartz AS: Neointima and arterial injury: dogs, rats, pigs and more. Lab Invest 1994;71:789-791

100. Okazaki $J$, Komori $K$, Kawasaki K, Eguchi D. Ishida M. Sugimachi K: L-Arginine inhibits smooth muscle cell proliferation of vein graft intimal thickness in hyperchalesterolemic rabbits. Cardiovasc
Res 1997;36:429-436.

101. Itoh $H$, Komori K. Funahashi $S_{\text {n }}$ Okadome $K$. Sugimachi $K$ : Intimal hyperplasia of experimental autologous vein graft in hyperlipidemic rabbits with poor distal unoff. Atherosclerosis

102. Schwartz SM, de Blois D. OBrien ERM: The intima. Soil for atherosclerosis and restenosis. Crrc Res 1995:77:445-465.

103. Jawien A. Bowen-Pope DF, Lindner V. Schwartz SM. Clowes AW: Platelet-derived growth factor promotes smooth muscle migration and intimal thickering in a rat model of balloon angioplasty. $J$
Clin Invest 1992;1992:507-511.

104. Ruel J, Meshel AS, Hu Z. Horaist C. Ballinger CA. Thompson LJ, Subbarao VD, Dumont JA, Patterson $\mathrm{C}$ : Flavoperidol inhibits smooth muscle cell proliferation in vitro and neointimal formation in vivo after carotid injury in the rat. Circulation 1999; 100:659-665. 
105. Lindner V. Reidy MA: Expression of basic fibroblast growth factor and its receptor by smooth muscle cells and endothelium in injured rat arteries. An en face study. Chrc Res 1993;73.589-595.

106. Arbustini E, de Servi S, Bramucci E, Porcu E, Costante AM, Grasso M, Diegoli M. Fasani R, Morbini P. Angoli L, Boscarini M, Repetto S. Danzi G, Niccoli L, Campolo L. Lucreziotti S. Specchia G: Comparison of coronary lesions abtained by directional coronaly atherectomy in unstable angina. stable angina, and restenosis after either atherectomy or angioplasty. Am $J$ Cardiol 1995;75:675682 .

107. Neschis DG, Safford SD, Hanna AK, Fox JC. Golden MA: Antisense basic fibroblast growth factor gene transfer early intimal thickening in a rabbit femoral artery balloon injury model, $J$ Vasc Surg $1998: 27: 126-134$

108. Smith JD. Bryant SR, Couper LL. Vary CPH, Gotwals PJ, Koteliansky VE, Lindner V: Soluble transforming growth factor-beta ype II receptor inhibits negative remodelingl, fibroblast differentiation and intimal lesion formation, but not endothelial growth. Circ Res 1999;84:12121222.

109. Daemen MJAP, Lombardi DM, Bosman FT, Schwartz SM: Angiotensin II induces smooth muscle cell proliferation in the normal and injured rat arterial wall. Circ Res 1991;68:450-456.

110. Ohishi M, Ueda M, Rakugi H, Okamura A, Naruko T, Becker AE, Hiwada K, Kamitani A, Kamide K. Higaki J. Ogihara T: Upregulation of the angiotensin-converting enzyme during the healing process after injury at the site of percutaneous transluminal coronary angioplasty in humans. Circulation 1997:96:3328-3337.

111. Stitt TN: The anticoagulation factor protein $S$ and its relative, gas6, are ligands for the Tyro 3/Axl family of receptor tyrosine kinases. Cell 1995;80:661-670.

112. Schneider $C$, King RM. Phillipson L: Genes specifically expressed at growth arrest of mammalian cells. Cell 1988; 54:787-793.

113. Goruppi S, Ruaro E, Schneider C: Gas6, the ligand of Axl tyrosine kinase receptor, has mitogenic and survival activities for serum starved NIH3T3 fibroblasts. Oncogene 1996:12:471-480.

114. Bellosta $P$, Zhang $Q$, Goff SP. Basilico C: Signalling through the ARK tyrosine thinase receptor protects trom apoptosis in the absence of growth stimulation. Oncogene 1997:15:2387-2397.

115. Li $R$, Chen J, Hammonds G, Phillips $H_{n}$ Armanini M, Wood P. Bunge $R$, Godowski P., Sllwkowski

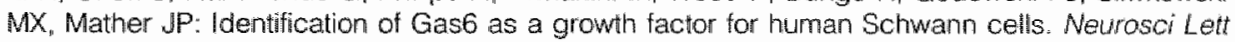
1996;16:2012-2019.

116. Avanzi GC, Gallicchio $M$, Cavalloni $G$, Gammaitoni $L$, Leone $F$, Rosina A, Boldorini $R$, Monga $G$ Pegoraro L, Varnum B, Aglietta M: Gas6, the ligand of Axl and Rse receptors, is expressed in hematopoietic tissue, but lacks mitogenic activity. Exp Hematol 1997;25:1219-1226.

117. Avanzi GC, Gallicchio M, Bottarel $F$, Gammaitoni L, Cavalloni $G$, Buonfiglio D. Bragarcio $M$, Bellomo G. Albano E, Fantozzi R, Garbarino G, Varnum B. Aglietta M. Saglio G, Dianzani $U$, Dianzani C: GAS6 inhibits granulocyte adhesion to endothelial cells. Blood 1998;91:2334-2340.

118. Fridell YWC, Villa J, Attar EC. Liu ET: GAS6 induces. Axl-mediated chemotaxis of vascular smooth muscle cells. J Biol Chem 1998:273:7123-7126.

119. Melaragno MG, Wuthrich DA, Poppa V. Gill D, Lindner V, Berk BC, Corson MA: Increased expression of Axl tyrosine kinase after vascular injury and regulation by $G$ protein-coupled receptor agonists in rats. Circ Res 1998;83:697-704

120. Berk BC, Corson MA: Angiotensin II signal transduction in vascular smooth muscle. Role of tyrosine kinases. Circ Res 1997:80:607-616.

121. Hu $Y$, Cheng $L$, Hochleitner $B W, X_{u} Q$ : Activation of mitogen-activated protein kinases (ERK/JNK) and AP-1 transcription facror in rat carotid arteries after balloon injury. Arteriascler Thromb VasC Biol 1997:17:2808-2816.

122. Ward MR, Agrolis A, Kanellakis P, Dilley $A$, Jennings $G$, Bobik A: Inhibition of protein tyrosine kinases attenuates increases in expression of Iransforming growth factor $\beta$ isoforms and their receptors following arterial injury. Arterioscler Thromb Vasc Biol 1997:17:2461-2470.

123. Kim S, Izumi $Y$, Yano $M$, Hannaguchi A, Miura K, Yamanaka S, Miyazaki $H_{\text {s }}$ Mwao H. Angiotensin blockade inhibits activation of mitogen-activated protein kinases in rall balloon-injured artery. Girculation 1998,97:1731-1737.

124. Morishita A, Gibbons G, Horiwchi M, Ellison KE, Nakajima M, Zhang L, Kaneda Y, Ogihara T, Dzau $\mathrm{VJ}$ : A. gene therapy strategy using a transcription factor decoy of the E2F binding site inhibits smooth muscle proliferation in wivo. Proc Natl Acad Sci U S A 1995:92:5855-5859. 
125. Cercek B, Yamashita M, Dimayuga P, Zhu J, Fishbein MC, Kaul S, Shah PK, Nilsson J, Regnstrom J: Nuclear factork $\mathrm{kB}$ activity and arterial response to balloon injury. Atherosclerosis 1997:131:5966.

126. Landry DB, Couper LL, Bryant SR, Lindner $V$ : Activation of the NF-kB and $1 k B$ system in smooth muscle cells after rat arterial injury. Induction of vascular cell adhesion molecule-1 and monocyte chemoattractant protein-1. Am J Pathol 1997:151:1085-1095.

127. Chen D, Krasinsiki $K$, Chen D, Sywester A. Chen J. Nisen PD, Andres V: Downregulation of cyclindependent kinase 2 activity and cyclin A promotor activity in vascular smooth muscle cells by p27kip 1, an inhibitor of neointima formation in the rat carotid artery. $J$ Clin Invest 1997;99:23342341.

128. Chang MW, Barr E, Lu MM, Barton $K$, Leiden JM: Adenovirus-mediated over-expression of the cyclin/cyclin-dependent kinase inhibitor. p21 inhibits vasculat smooth muscle cell proliferation in the rat carotid artery model of balloon angioplasty. J Clin Invest 1995;96:2260-2268.

129. Mann MJ. Gibbons GH, Tsao PS, won der Leyen HE, Cooke JP B Buitrago $R$, Kernoff R, Dzau VJ: Cell cycle inhibition preserves endothelial function in genetically engineered rabbit vein grafts. $J$ Cin trivest 1997-99:1295-1301.

130. Yang ZY. Simari RD, Perkins ND. San H. Gordion D, Nabel GJ, NAbel EG: Role of the p21 cyclindependent kinase inhibitor in limiting intimal cell proliteration in response to arterial injury. Proc Natl Acad SciU S A 1996:93:7905-7910.

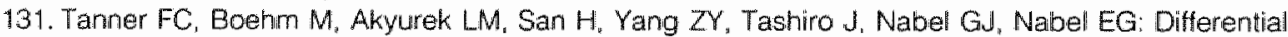
effects of the cyclin-dependent kinase inhibitors p.27, p21, and p16 on vascular smooth mucle cell proliferation. Circulation 2000: 101:2022-2025.

132. Gallo R, Padurean A, Jayaraman T. Marx S, Roque M. Adelman S, Chesebro J, Fallon J, Fuster V. Marks A, Badimon Jul: Inhibition of intimal thickening after balloon angioplasty in porcine coronary arteries by targeting regulators of the cell cycle. Circulation 1999:99:2164-2170.

133. Nabel EG: Gene therapy for vascular diseases. Atherosclerosis $1995 ; 118: 551-556$.

134. Indoffi G, Chiariello M. Avvedimento EV: Selective gene therapy for proliferative disorders: sense and antisense. Nat Mad 1996;2:634-635.

135. Mann MU, Gibbons GH, Kernoff RS, Diet FP. Tsao PS, Cooke JP, Kaneda Y, Dzau V: Genetic engineering of vein grafts resistant to atherosclerosis. Proc Natl Acad Sci U S A 1995;92:45024506.

136. Marek JM, Koehler $C$. Aguirre ML, Westerband A Gentile AT, Mills JL, Hunter GC: The histologic characteristics of primary and restenotic carotic plaque. J Surg Ries 1998;74:27-33.

137. Maresta A, Balducelli M. Cantini L, Casari A, Chioin R, Fabbri M, Fontanelli A, Preti PAM, Repetto S, De Servi S, Varani E: Trapidil (triazolopyrimidine), a platelet-derived growth factor antagonisit, reduces restenosis after percutaneous transluminal coronary angioplasty. Results of the randomized, double-blind STARC study. Circulation 1994;90:2710-2715.

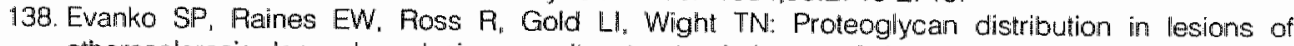
atherosclerosis depends on lesion severity, structural characteristics, and the proximity of plateletderived grwoth factor and transforming growth factor- $\beta$. Am J Pathol $1998,152.533-546$.

139. Wei GL, Krasinski K. Kerney $M_{n}$ Isner JM. Walsh K. Andres V: Temporally and spatially coordinated expression of cell cycle regulatory factors after angioplasty. Circ Res 1997:80:418-426.

140. Speir E. Modali R, Huang ES. Leon MB, Shaw F. Finkel T. Epstein SE: Potential role of human cytomegalovirus and p53 interaction in coronary restenosis. Science 1994:265:391-394.

141. OBiten EA, Alpers CE, Stewart DK, Ferguson M, Tran N, Gordon D. Benditt EP, Hinohara $T$ Simpson JB. Schwartz SM: Proliferation in primary and restenotic coronary atherectomy tissue. Implications for antiprolfferative therapy. Circ Res 1993;73:223-231.

142. Taylor AJ, Farb AA, Angello DA, Burwell LR, Virmani $R$ : Proliterative activity in coronary atherectomy tissue. Clinical, histopathologic and immunohistochemical correlates. Chest $1995: 108: 815-820$

143. Mann MU, Whittemore AD, Donaldson MC. Belkin M, Conte MS. Polak JF, Orav EJ, Ehsan A. Dell'Acqua G, Dzau VJ: Ex-vivo gene therapy of human vascular bypass grafts with E2F decoy: the PREVENT single-centre, randamized, controlled trial. Lancet 1999;354:1493-1498.

144. Faxon DP: Effect of high dose angiotensin-converting enzyme inhibition on restenenosis: final results of the MERCATOR study, a multicenter, double blind, placebo-controlled trial of cilazapril. Am Coll Cardiol 1995:25:362-369. 
145. Kockx MM. De-Meyer GR, Muhring J. Bult H. Bultinck J, Herman AG: Distribution of cell replication and apoptosis in atherosclerotic plaques of cholesterotfed rabbits. Atheroscterosis 1996; 120:115 124.

146. Stary HC, MCMillan GC: Kinetics of cellular proliferation in experimental atherosolerosis. Radioautoradiography with grain counts in cholesterol-fed rabbits. Arch Path 1970:89:173-183.

147. Chang MY, Sasahara M, Chait A, Raines EW, Ross R: Inhibition of hypercholesterolemia-induced atherosclerosis in the non-human primate by probucol. Il. Cellular composition and proliferation. Arterioscler Thromb Vasc Biol 1995;15:1631-1640.

148. Inling $C$. Menzel G, Wellens E. Schulte Monting J. Schaeler HE, Zeiher AM: Topographical association between the cyclin-dependent kinases inhibitor p21,p53 accumulation and cellular proliferation in human atherosclerotic tissue. Arterioscler Thromb Vasc Biol 1997:17:2218-2224.

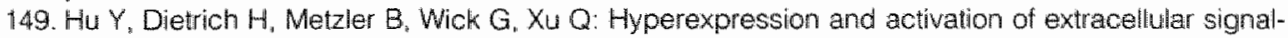
regulated kinases (ERK1/2) in atherosclerotic lesions of cholesterol-fed rabbits. Auterioscler Thromb Vasc Biol 2000;20:18-26.

150. Liau G, Winkles JA, Cannon MS, Kuo L. Chilian WM: Dietary-induced atheroscierotic lesions have increased levels of acidic FGF mRNA and altered cytoskeletal and extracellular matrix mRNA expression. J Vasc Res 1993;30:327-332.

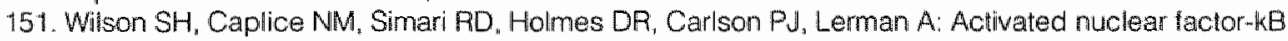
is expressed in the coronary vasculature in experimental hypercholesterolemia. Alherosclerosis $2000: 148: 23-30$.

152. Liao $F$, Andalibi A, deBeer FC. Fogelman AM, Lusis Ad: Genetic control of inflammatory gene induction and $\mathrm{NF}-\mathrm{kB}$ like transcription factor activation in response to an atherogenic diet in mice. $J$ Clin Invest 1993;91:2572-2579.

153. Guevara NV. Kim HS, Antonova El, Chan L: The absence of $p 53$ accelerates atherosclerosis by increasing cell proliferation in vivo. Nat Med 1999;5:335-339.

154. Inling $C$, Haendeler J, Menzel G. Hess RD, Fraedrich G, Scheafer HE, Zeiher AM: Co-expression of $p 53$ and MDM2 in human atherosclerosis: implications for the regulation of cellularity of atherosclerotic lesions. J Pathol 1998; 185:303-312.

155. Rekhter MD, Gordon D: Active proliferation of different cell types, including lymphocytes, in human atherosclerotic plaques. Am J Pathol 1995; 147:668-677.

156. Gordon D, Reidy MA, Benditt EP. Schwartz SM: Cell proliferation in human coronary arteries. Proc Natl Acad Sci U S A 1990;87:4600-4604.

157. Brandl R, Richter T, Haug K, Wilhelm MG, Maurer PC, Nathrath W: Topographic analysis of proliferative activity in carotid endarterectomy specimens by immunocytochemical detection of the cell cycle-related antigen Ki-67. Circulation 1997;96:3360-3368.

158. Orekhov AN. Andreeva ER, Mikhailova IA, Gordon $D$ : Cell proliferation in normal and atherosclerotic human aorta: proliferative splash in lipid-rich lesions. Arteriosclerosis 1998; 139:4148.

159. Villaschi S, Spagnoli LG: Autoradiographic and ultrastructural studies on the human fibroatheromatous plaque. Atherosclerosis 1983;48:95-100.

160. Orekhov AN, Kosykh VA, Repin VS, Smirnow VN: Cell proliteration in normal and atherosclerotic aorta. II. Autoradiographic observation on deoxyribonucleic acid synthesis in primary cell culture. Lab invest 1983; $48: 749$ 754.

161. Ross R, Masuda J. Raines EW, Gown AM, Katsuda S, Sasahara M, Malden LT, Masuko H. Sato H: Localisation of PDGF-B protein in macrophages and all stages of atherosclerosis. Science 1990;248:1009-1012.

162. Bourcier $T$, Sukhova $G$, Libby $P$ : The nuclear lactor $k-B$ signaling pathway participates in dysregulation of vascular smooth muscle cells in vitro and in human atherosclerosis. J Biol Chem $1997: 272: 15817-15824$

163. Ihling $C$. Technau $K$, Gross $V$. Schulte-Monting J, Zeiher AM, Schaefer HE: Concordant upregulation of type II-TGF- $\beta$-receptor the cyclin-dependent kinases inhibitor p27Kip 1 and cyclin E in human atherosclerotic tissue: implications far lesion cellularity. Atherosclerosis 1999; 144:7-14.

164. Tanner FC, Yang ZY. Duckers E, Gordon D. Nabell Ga, Nabel EG: Expression of cyclin-dependent kinase inhibitors in vascular disease. Circ Res 1998;82:396-403.

165. Matsushita $H$, Morishita $R$, Aoki M, Tomita $N$, Taniyama $Y$, Nakagami $H$, Shimozato T, Higaki $J_{\text {. }}$ Kaneda $Y$, Ogihara $T$ : Transfection of antisense p53 fumor suppressor gene 
oligodeoxynucleotides into rat carotid antery results in abnomal growth of vascular smooth muscie cells. Circulation 2000; 101:1447-1452.

166. Scheinman M. Ascher $E$, Levi GS, Hingorani A, Shirazian D. Seth P: p53 gene transfer to the injured rat carotid artery decreases neointimal formation. J Vasc Surg 1999:29:3e0-369.

167. Best PJM, Hasdai D. Sangiongi G. Schwartz PS, Holmes DR, Simari RD, Lerman A: Apoptosis. Basic concepts and implications in coronary artery disease. Arterioscler Thromb Vasc Biol $1999: 19: 14-22$.

168. Maino G. Joris : Apoptosis, oncosis, and necrosis. An overview of cell death. Am $J$ Pathol $1995: 146: 3-15$.

169. Schwartz SM, Bennett MA: Death by any other name. Am J Pathol 1995; 147:229-234

170. Kockx MM, Knaapen MW: The role of apoptosis in vascular disease. J Pathol 2000; 190:267-280.

171. Kockx MM, Herman AG: Apcptosis in atherosclerosis: beneficial or detrimental? Cardiovasc Res $2000 ; 45: 736 \% 746$

172. Han DKM, Haudenschild CCH, Hong MK, Tinkle BT. Leon MB, Lau G: Evidence for apoptosis in thuman atherogenesis and in a ral vascular iniury model. Am J Pathol 1995;147:267-277.

173. Malik N, Francis SE. Holt CM. Gunn J. Thomas GL, Shepherd L, Chamberlain J. Newman CMH, Cumberland DC, Crossmanm DC: Apoptosis and cell profiferation after porcine coronary angioplasty. Circulation 1998;98:1657-1665.

174. Luo Z, Sata M. Nguyen T, Kaplan JM, Akita GY, Walsh K: Adenovirus-mediated delivery of Fasligand inhibits intimal hyperplasia after balloon injury in immunologically primed animals. Circulation 1999;99:1776-1779.

175. Sata M, Perlman H, Muruve DA, Silver M, lkebe M. Libermann TA. Oettgen P. Walsh K: Fas ligand transfer to the vessel wall inhibits neointima formation and overrides the adeno-virus-mediated $T$. cell response. Proc Natl Acad SCI U S A 1998:95:1213 1217.

176. Hayakawa $Y$. Takemura $G$. Misao J, Kanoh $M$, Ohno $M$, Ohashi $H$. Takatsu $H_{*}$ ito $H$, Fukuda $K$, Fujiwara $T$. Minatoguchi $S_{*}$ Fujwara $H$ : Apoptosis and overexpression of Bax protein and bax mFNA in smooth muscle cells within intimal hyperplasia of human radial arteries. Analysis with arteriovenous fistulas used for hemodialysis. Arterioscier Thromb Vase Biol 1999;19:2066-2077.

177. Igase M. Okura T, Kitami $Y$, Hiwada $K$ : Apoptosis and BCl-xS in the intimal thickening of ballooninjured carotid arteries. Clin Sci 1999;96:605-612

178. McMillan GC: development of arteriosclerosis. Am J Cardiol 1973;31:542-546.

179. Niebauer J, Schwarzacher SP, Hayase M. Wang B, Kernoff RS, Cooke JP, Yeung AC Local LArgenine delivery after balloon angioplasty reduces monocyte binding and induces apoptosis. Circulation 1999; 100:1830-1835.

180. Isner JM, Kearney M. Bortman S, Passeri J: Apoptosis in human atherosclerosis and restenosis. Circulation 1995,91:2703-2711.

181. Bauriedel, Schiluckebier $S$. Hutter $R$, Welsch U, Kandolf R, Luderitz B. Prescott M: Apoptosis in restenosis versus stable-angina atherosclerosis. Implications for the pathogenesis of restenosis Arterioscler Thromb Vasc Biol 1998; 18:1132-1139.

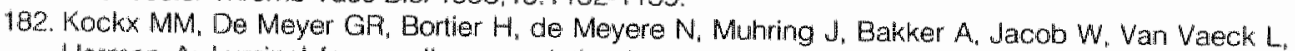
Herman A: Luminal foam cell accumulation is associated with smooth muscle cell death in the intimal thickening of human saphenous vein grafts . Circulation 1996;94:1255-1262.

183. Kockx MM, Cambier BA. Bortier HE, De Meyer GR, Declercq SC. van Cauwelaen PA, Bultinck J: Foam cell replication and smooth muscle cell apoptosis in human saphenous vein grafts. Histopathology 1994:25:365-371

184. Geng $Y J$, Libby P: Evidence for apoptosis in advanced human atheroma. Colocalization with interleukin-1 betta-converting enzyme. Am I Pathol 1995; 147:251-266.

185. Bjökerud S. Björkerud B: Apoptosis is abundant in human atherosclerotic lesions, especially in inflammatory cells (macrophages and $T$ cells), and may contribute to the accumulation of gruel and plaque instability. Am J Pathol 1996; 149:367-380.

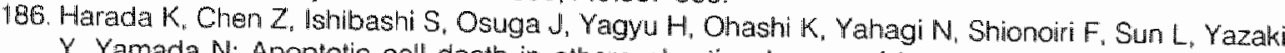
$Y$. Yamada N: Apoptotic cell death in atherosclerotic plaques of hyperlipidemic knockout mice Atherosclerosis 1997; 135:235-239.

187. Shindo J, Ishibashi T, Yokoyama $K$. Nakazato K. Onwada T, Shiomi M, Maruyama Y: GranulocyteMacrophage Colony stimulating factor prevents the progression of atherosclerosis via changes in the cellular and extracellular composition of atherosclerotic lesions in Watlanabe heritable hyperlipidemic rabbits. Circulation 1999:99:2150-2156. 
188. Kockx MM, de Meyer GRY, Buyssens N. Knaapen MWM. Bult H. Herman AG: Cell composition. replicalion, and apoptosis in atherosclerotic plaques after 6 months of cholesterol withdrawal. Circ Res 1998;83:378-387.

189. Schneider DB, Vassalli $G$, Wen S, Driscoll RM, Sassani AB, DeYoung MB, Limnemann R, Virmani $P_{\text {, }}$ Dichek DA: Expression of Fas ligand in arteries of hypercholesterolemic rabbits accelerates atherosclerotic lesion formation. Arterioscler Thromb Vasc Biol 2000,20:298-308.

190. Davies MJ, Woolf N, Rowles P. Richardson PD. Lipid and cellular constituents of unstable human aortic plaques. $1995: 33-39$.

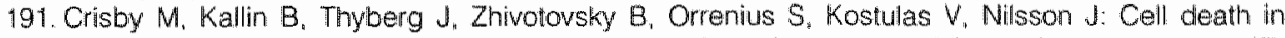
human atherosclerotic plaques inwolves both oncosis and apoptosis. Atherosclerosis 1997; 130:1727.

192. Kockx MM, de Meyer GRY, Muhring J, Jacob W, Bult H. Herman AG: Apoptosis and related proteins in different stages of human atherosclerotic plaques. Chculation 1998:98:2307-2315.

193. Imanishi T, McBride J, Ho Q. O'Brien KD, Schwartz SM, Han DKM: Expression of cellular FLICEinhibitory protein in human coronary arteries abd in a rat wascular injury model. Am $J$ Pathol $2000 ; 156: 125 \times 137$.

194. Cai WJ, Devaux B. Schaper W. SchaperJ: The role of FASIAPO 1 and apoptosis in the development of human atherosclerotic lesions. Atherosclerosis 1997;131:177-186.

195. Rowe VL, Stevens SL, Reddlick TT. Freeman MB, Donnell $\mathrm{A}$, Carroll RC, Goldman MH: Vascullar smooth muscle cell apoptosis in aneurysmal, occlusive and normal human aortas. I Vasc Surg $2000 ; 31: 567-576$.

196. Robins Pathologic basis of disease, 6th ed, Cotran, Kumar and Collins, Saunders, Philadelphia, USA, Chapter 3, pages 50-88.

197. Pathology, $2^{\text {ndi }}$ ed, Rubin and Farber, JB Lipincoti company, Philadelphia, USA, chapter 2, pages 32-67.

198. Clark EA: CD40: a cytokine receptor in search of a ligand. Tissue Antigens 1990;36:33.

199. Foy TM, Aruffo A, Bajorath J, Buhlimann JE. Noelle AJ: Immune regulation by CD40 and its ligand GP39. Annu Rev Immunol 1996; 14:591-617.

200. van Kooten C, Banchereas J: CD40-CD40 ligand: a multifunctional receptor-ligand pair. Actv Immunol 1996;61:1-77.

201. Grewall IS. Flavell RA: A central role of CD40 ligand in the regulation of CD4 $+T$-cell responses. Immunol Today 1996:17:410-414.

202. Aruffo A, Farrington M, Hollenbaugh D, Li X, Milatovich A, Nonoyama S, Bajorath J, Grosmaire LS, Stenkamp R, Neubauer M, Roberts RL, Noelle RJ, Ledbetter UA, Francke U, Ochs HD: The CD40 ligand, gp39, is defective in activated T cells from patients with X-linked hyper-lgM syndrome. Cell $1993 ; 72: 291-300$.

203. Xu J. Foy TM, Laman JD, Elliott EA, Dunn JJ, Waldschrnidt TJ, Elsemore J, Noelie RJ, Flavell RA. Mice deficient for the CD40 ligand. Immunity 1994:1:423-431.

204. Renshaw BRi, Fanslow WC. Armitage RJ, Campbell KA, Liggitt D, Wright B. Devison BL. Maliszewski CF: Humoral immune response in CO40 ligandudeficient mice. \& Exp Med 1994;180: 1889-1900

205. Campbell KA, Ovendale PJ, Kennedy MK, Fanslow WC. Reed SG, Maliszewski CR: CD40 ligand is required for protective cell-mediated immunity to Leishmania major. Immunity 1996,4:283-289.

206. Lei XF, Ohkawara $Y$, Stamptil MR, Mastruzzo C, Marr RA, Snider D, Xing Z, Jordana M: Disruption of antigen-induced inflammatory responses in CD40 ligand knockout mice. I Clin thvest $1998: 101: 1342-1353$.

207. Alderson MR, Armitage RJ, Tough TW. Strockbine L. Fanslow WC, Spriggs MK: CD40 expression by human monocytes: Regulation by cytokines and activation of monocytes by the ligand for CD40. J Exp Med 1993;178:669-674.

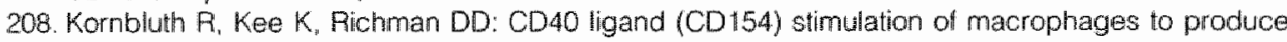
HIV-1-suppressive B-chemokines. Proc Nall Acad Sci U S A 1998995:5205-5210.

209. Yellin MJ, Brett J, Baum D. Matsushima A, Szabolcs M, Stern D. Chess L: Functional interactions of $T$ cells with endothelial cells: The role of CD4OL-CD40-mediated signals. Exp Med 1995:182:1857-1864.

210. Yellin MJ. Winikoff S, Fortune SM, Baum D, Crow MK, Lederman S, Chess L: Ligation of CD40 on fibroblasts induces CD54 (ICAM-1) and CD106 (VCAM-1) upregulation and II-6 production and proliferation. J Leukoc Biol 1995;58:209-216. 
211. Karmann K, Hughes CCW. Schechner J. Fanslow WC. Pober JS: CD40 on human endothelial cells: inducibility by cytokines and functional regulation of adhesion molecule expression. Proc Natl Acad Sci U S A 1995:92:4342-4346.

212. Dechanet J, Grosset $C$, Taupiry J M. Merville P. Banchereau J. Pipoche J, Moreau JF: CD40 ligand stimulates proinflammatory cylokine production by human endothelial cells. J Immunol $1997: 159: 5640-5647$

213. Smith RS, Smith TJ, Elieden TM. Phipps RP: Fibroblasts as sentinel cells. Synthesis of chemokines and regulation of intlammation. Am J Pathol 1997;151:317-322.

214. Schönbeck U. Mach F. Bonnetoy JY. Loppnow H. Flad HD. Libby P. Ligation of CD40 activtes interleukin $1 \beta$-converting enzyme (caspase-1) activity in vascular smooth muscle and endotheliai cells and promotes elaboration of active interleukin 1B. J Biol Chem 1997:272:19569-19574.

215. Kiener PA, Moran-Davis P, Rankin BM, Wahi AF, Aruffo A, Hallenbaugh D: Stimulation of CD40 with purified soluble gp39 induces proinfiammatory responses in human monocytes. I immunol $1995 ; 155: 4917-4925$.

216. Durie FH, Fava RA, Foy TM, Aruffo A, Ledbetter JA, Noelle RJ: Prevention of collagen-induced arthritis with an antibody to gp39, the ligand for CD40. Science 1993:261:1328-1330.

217. Gerritse K, Laman JD, Ncelle R, Aruffo A, Ledbetter JA, Boersma WJA, Claassen E: CD4O-CD40 ligand interactions in experimental allergic encephaliomyelitis and multiple sclerosis. Proc Naty Acad Sci U S A 1996:93:2499-2504.

218. Reul RM. Fang JC, Denton MD, Geehan C. Long C, Mitchell PN, Ganz P. Briscoe DM: CD 4O and CD40 ligand (CD154) are coexpressed on microvessels in vivo in human cardiac allograft rejection. Transplantation 1997;64:1765-1774.

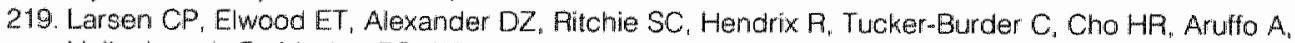
Hollenbaugh D. Linsley PS. Winn KJ. Pearson TW: Long-term acceptance of skin and cardiac allografts after blocking CD40 and CD28 pathways. Nature 1996;381:434-438.

220. Lu L. Li W. Fu F. Chambers FG, Oian S, Fung JJ, Thomson AW: Blockade of the CD40-CD40 ligand pathway potentiates the capacity of donor-derived dendritic cell progenitors to induce longterm cardiac allograft survival. Transplantation 1997:64:1808-18:15.

221. Howard LM, Miga AJ, Vanderlugt CL, Dal Canto MC, Laman dD, Noelle RJ, Miller SD Mechanisms of immunotherapeutic intervention by anti-CD40L. (CD154) antibody in an animal model of multiple sclerosis. I Clin Invest 1999; 103:281-290.

222. Adawi A. Zhang $Y$. Baggs $R$, Rubin P, Williams J, Finkelstein J, Phipps RP. Blockade of CD40$\mathrm{CD} 40$ ligand interactions protects against radiation induced pulmonary inflammation and fibrosis. Clin Immunol Immunopath 1998;89:222-230.

223. Emeson EE, Robertson AL: T lymphocytes in aortic and coronary intimas. Their potential role in atherogenesis. Am J Pathol 1988; 130:369-376.

224. Erren M. Reinecke H, Junker F, Fobker M. Sculte H. Scurek JO. Kropf J, Kerber S. Breithardt $G$, Assmann $G$, Cullen $P$. Systemic infiammatory parameters in patients with atherosclerosis of the coronary and peripheral arteries. Arterioscler Thromb Vasc Biol 1999; 19:2355-2363.

225. Aukrust P, Muller F. Ueland T, Bergett T, Aaser E, Brunswig A. Solum NO. Forfang K. Froland SS Gullestad L: Enhanced levels of soluble and membrane-bound CD40 ligand in patients with unstable angina. Possible reflection of T-lymphocyte and platelet involwement in the pathogenesis of acute coronary syndromes. Circulation 1999; 100:614-620

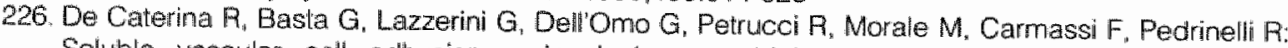
Soluble vascular cell adhesion molecule-1 as a biohumeral correlate of atherosclerosis. Arterioscler Thromb Vasc Biol 1997;17:2646-2654.

227. Mazzone A, De Servi S, Vezzoli M, Fossati G, Mazzucchelli I, Gritti D, Ottini E, Mussini A, Specchia G: Plasma levels of interleukin 2, 6, 10 and phenotypic characterization of circulating $T$ lymphocytes in ischemic heart disease. Atheroscherosis 1999:145:369-374.

228. Grainger DJ, Kemp PR, Metcalfe JC, Liu AC, Lawn RM. Williams NR, Grace AA, Schofield PM, Chauhan $A$ : The serum concentration of active transforming growth factor-beta is severely depressed in advanced atherasclerosis. Nat Med 1995; 1:74-79.

229. Kol A, Libby P: Molecular mediators of arterial inflammation: a role for microbial products. Am Heart J 1999:138:S450-S452.

230. Epstein SE, Zhou YF, Zhu J. Potentiall role of cytomegalovirus in the pathogenesis of restenosis and atherosclerosis. Am Heart $\$ 1999$; $138: S 476-\$ 478$. 
231. Ma-Herttuala S, Palinsky W, Rosenfeld ME, Parthasarathy S, Carew TE, Butler S, Witztum Jt-. Steinberg $D$. Evidence tor the presence of oxidatively modified low density lipoprotein in atherosclerotic lesions of rabbit and man. J Chin invest 1989;84:1086-1095.

232. Palinsky $W$. Tangirala RK. Miller E, Young SG. Witztum Uh: increased autoantibody titers against epitopes of oxidized LDL in LDL receptor-deficient mice with imcreased atherosclerosis. Arierioscler Thromb Vasc Biol 1995;15:1569-1576.

233. Nakashima Y, Plaines EW, Plump AS, Breslow JL. Ross R: Upregulation of WCAM-1 and ICAM-1 at atherosclerosis-prone sites on the endothelium in the apoE-deficient mouse. Arterioscler Thromb Vasc Biol 1998; 18:842-851.

234. Richardson M. Hadcock Su, DeReske M, Cybulsky Ml: Increased expression in vivo of VCAM-1 and E-selectin by the aortic endothelium of normolipemic and hyperlipemic diabetic rabbits. Arterioscler Thromb Vasc Biol 1994:14:760-769.

235. Tenaglia AN, Buda AJ, Wilkins RG. Barron MK, JEffords PR, Vo K, Jordan MO, Kusnick BA, Lefer D.: Levels of expression of P-selectin, E-selectin, and intracellular adhesion molecule-1 in coronary atherectomy specimens from patients with stable and unstable angina pectoris. Am $J$ Cardiol 1997;79:742-747.

236. Poston AN, Haskard DO, Coucher JR, Gall NP, Johnson-Tidey RR: Expression of intercellular adhesion molecule-1 in atherosclerotic plaques. Am J Pathol 1992; 140:665-673.

237. Ya-Herttuala S, Lipton BA, Rosenfeld ME, Sarkioja T, Yoshimura T, Leonard EJ, Witztum J. Steinberg D: Expression of monocyte chemoattractant protein-1 in macrophage-rich areas of human and rabbit atherosclerotic lesions. Proc Nat Acad Sci US A 1991:88:5252-5256.

238. Rosenfeld ME, Yla-Herttuala S, Lipton BA, Ord VA, Witztum JL. Steinberg D: Macrophage colonystimulating factor mRNA and protein in atherosclerotic lesions of rabbits and humans. Am J Pathol 1992,140:291-300.

239. Tipping PG. Hancock WW: Production of tumor necrosis factor and interleukin-1 by macrophages from human atheromatous plaques. Am J Pathol 1993;142:1721-1728.

240. Moyer CF. Sajuthi D. Tulli H, Williams JK: Synthesis of IL-1 alpha and IL-1 beta by arterial cells in atherosclerosis. Am J Pathol 1991;138:951-960.

241. Rus $H G$, Vaincu R. Niculescu F: Interleukin-6 and interleukin-8 protein and gene expression in human arterial atherosclerotic wall. Atherosclerosis 1996:127:263-271.

242. Sukovich DA, Jauser K. Shirley FD, DelVecchio V, Halks-Miller M. Rubanyi GM: Expression of interleukin-6 in atheroscierotic lesions of male ApoE-knockoul mice. Inhibition by 17B-estradiol. Arterioscler Thromb Vasc Biol 1998:18:1498-1505.

243. Warren JM, Ralph P: Macrophage growth factor CSF-1 stimulates human monocyte production of interferon, tumor necrosis factor, and colony stimulating activity. I Immunol 1986;137:2281-2285.

244. Uyemura K, Demer LL, Castle SC, Jullien D, Berliner JA, Gately MK, Warriør PR, Pham N, Fogelman AM, Modlin RL: Cross-regulatory roles of interleukin (IL)-12 and IL-10 in atherosclerosis. JClin Invest 1996;97:2130-2138.

245. Nikkari ST, O'Brien KD, Ferguson M, Hatsukami T, Welgus HG. Alpers CE, Clowes AW: Interstitial collagenase (MMP-1) expression in human carotid atherosclerosis. Circulation 1995;92: 1393-1398.

246. Galis ZS, Sukhova GK, Kranzhöfer R, Clark S, Libby P: Macrophage foam cells from experimental atheroma constitutively produce matrix-degrading proteases. Proc Nall Acad Sci U S A. $1995 ; 92: 402-406$.

247. Galis, ZS, Muszynski M. Sukhova GK, Simon-Morrissey E, Libby P: Enhanced expression of vascular matrix metalloproteinases induced in vitro by cytokines and in regions of human atherosclerotic lesions. Ann N Y Acad Sci 1995; 748:501-507.

248. Galis ZS. Sukhova GK, Lark MW. Libby P: Increased expressiom of matrix metalloproteinases and matrix degrading activity in vulnarable regions of human atheroscleratic plaques. I Clin invest $1994: 94: 2493-2503$

249. Collins RG. Velji $R$, Guevara NV, Hicks MJ. Chan L, Beauder AL: P-selectin or intercellular adhesion molecule (ICAM)-1 deficiency substantially protects against atherosclerosis in apolipoprotain E deficient mice J Exp Med 2000; 191:189-194.

250. Nageh MF, Sandberg ET. Marotti KF, Lin AH, Melchior EP, Bullard DC, Beaudet AL. Deficiency of inflammatory celf adthesion molecules protects against atherosclerosis in mice. Arterioscler Thromb Vasc Biol 1997; 17:1517-1520.

251. Dong ZM, Chapman SM, Brown AA, Frenette PS, Hynes RO. Wagner DD: The combined role of P. and E-selectins in atherosclerosis, J Clin lovest 1998; 102:145-152 
252. Johnson RC. Chapman SM, Dong ZM, Ordovas JM, Mayadas TN, Herz J, Hynes RO. Schaefer Ed. Wagner DD: Absence of P-selectin delays fathy streak formation in mice. I Chin Inuest 1997:99:1037-1043

253. Aiello FJ. Bourassa PAK. Lindsey S, Weng W. Natoli E, Rollins BJ, Milos P: Monocyte chemoattractant protein-1 accelerates atherosclerosis in apolipoprotein E-deficient mice Arterioscler Thromb Vasc Biol 1999, 19:1518-1525.

254. Gu L, Okada Y, Clinton SK, Gerard C. Suknova GK, Libby P. Rollins B.l: Absence of monocyte chemoattractant protein-1 reduces atherosclerosis in low density lipoprotein receptor-deficient mice. Mol Cell 1998:2:275-281.

255. Dawson TC, Kuziel WA, Osahar TA, Maeda N: Absence of CC chemokine receptor-2 reduces atherosclerosis in apolipoprotein E-deficient mice. Atherosclerosis 1999:143:205-211.

256 Qiao J, Tripathi J, Mishra NK. Cai Y. Tripathi S, Wang X. Imes S. Fishbein MC. Clinton SK, Libby P. Lusis Au. Rajavashisth TB: Role of macrophage colony-stimulating factor in atherasclerosis. Studies of osteppetrotic mice. Am J Pathol 1997:150:1687-1699.

257. Rajavashisth T, Qiao JH. Tripathi S, Tripathi J, Mishra N, Hua M, Wang XP, Loussararian A, Clinton $S$. Libby $P$. Lusis A: Heterozygous osteopetrotic (op) mutation reduces atherosclerosis in $L D L$. receptor-deficient mice. J' Clin lovest 1998; 1012702-2710.

258. Huber SA, Sakkinen $P$, Conze $C_{r}$ Hardin $\mathbb{N}$, Tracy $R$ : Interleukin-6 exacerbates early atherosclerosis in mice. Anterioscler Thromb Vasc Biol 1999;19:2364-2367.

259. Gupta S, Pablo AM, Jiang XC, Wang N, Tall AR, Schindler $C$ : IFN-y potentiates atheroscierosis in ApoE knock-out mice. J Clin Invest 1997;99:2752-2761.

260. Tellides $\mathrm{G}$, Tereb DA, Kirkilles-Smith NC, Kim RW, Wilson JH, Schechner JS, Lorber M. Pober JS: Interferon- $\gamma$ elicits arteriosclerosis in the absence of leukocytes. Nature 2000:403:207-211.

261. Pinderski Oslund Ld, Hedrick CC. Olvera T, Hagenbaugh A, Territo M. Berliner JA, Fyle Al: Interleukin- 10 blocks atherosclerotic events in witro and in vivo. Arterioscler Thromb Vasc Biol $1999 ; 19: 28.47-2853$.

262. Mallat Z, Besnard $S_{n}$ Duriez M. Deleuze V $H$. Fievet C, Staels B, Duwerger N. Scherman D. Tedgui A: Protective role of interleukin-10 in atherosclerosis. Circ Res 1999;85.

263. Rouis M. Adamy G. Duverger N. Lesnitk. P. Horellou P. Moreau M. Emmanuel F, Caillaud JM. Laplaud PM, Dachet C. Chapman ML: Adenovirus-mediated overexpression of tissue inhibitor of metalloproteinase-1 reduces atheroscleratic lesions in apolipoprotein E-deficient mice. Circulation $1999,100: 533-540$.

264. Khan BV. Parthasarathy SS, Alexander FW, Medford RM: Modified low density lipoprotein and its constituents augment cytokine-activated vascular cell adhesion molecule-1 gene expression in human vascular endothelial cells. A Clin invest 1995:95:1262-1270.

265. Klouche $M$, May AE. Hernmes M, Messner M. Kanse SM. Preissner KT. Bhakdi S: Enzymatically modified, nonoxidized LDL induces selective adhesion and transmigration of monocytes and $T$. Iymphocytes through human endothelial cell monolayers. Arterioscher Thromb Vasc Biol $1999 ; 19: 784-793$

266. Vora DK, Fang ZT, Liva SM. Tyner TR, Parhami F, Watson AD. Drake TA, Territo MC, Berliner JA: Induction of P-selectin by oxidized lipoproteins. Seperale effects on synthesis and surface expression. Circ Res 1987:80:810-818.

267. de Villers WUS, Fraser IP, Hughes DA, Doyle AG, Gordon S: Macrophage-Colony-stimulating lactor selectwely enhances macrophage scavenger expression and function. I Exp Med 1994:180:705-709.

268. Stanley ER, Guilbert LJ. Tushinski PJ, Bartelmez SH: CSF-1-A mononuclear phagocyte lineage specific hemopoietic growth factor. J Cell Biochem 1983:21:151-159.

269. Tushinsky RJ, Olive IT. Gulibert LJ, Tynan PW, Warner JR. Stanley ER: Survival of mononuclear phagocytes depends on a lineage-specific growth factor that the differentated cells selectively destroy. Cell 1982;28:71-77.

270. Krieger M. Herz J: Structures and functions of multiligand lipoprotein receptors: macrophage scavenger receptors and LDL receptor-related protein (LRP). Annu Rev Biochem 1994;63:601. 637.

271. de Winther MPJ. Willems van Dijk K. Havekes LM. Hofker MH: Macrophage scavenger receptor class A. A multifunctional receptor in atherosclerosis. Arterioscler Thromb Vasc Biol 2000,20:290. 297. 
272. Brooks-Wilson A, Marcil M, Clee SM, Zhang LH, Roomp K, van Dam M, Yu L. Brewer C, Collins JA, Molhuizen HOF, Loubser O. Ouelette BFF, Fichter K. Ashbourne-Excofton KJD, Sensen CW. Scherer S, Mott S. Denis M, Nartindale D, Frohlich J, Morgan K, Koop B. Pimstone S, Kastelein JP. Genest J.JP. Hayden MR: Mutations in ABC1 in Tangier disease and tamilial high density lipoprotein deficiency. Nat Gen 1999;22:336\%345.

273. Orso E. Broccardo C. Kaminski WE. Botzcher A, Liebisch G. Drobnik W. Gotz A, Chambenoit O. Diederich W, Langmann $T$, Spruss $T$, Luciani MF, Rothe $G$, Lackner KJ, Chimini $G$, Schmitz $G$ : Transport of lipids from golgi to plasma membrane is defective in Tangier disease and abc1. deficient mice. Nat Gen 2000;24:192-196.

274. Terkeltaub $R$, Boiswert WA, Curtiss LK: Chemokines and atherosclerosis. Curr Op Lipidor 1998:9:397 405 .

275. Weber C. Alon R. Moser B. Springer TA: Sequential regulation of $\alpha 4 \beta 1$ and $\alpha 5 \beta 1$ integrin activity by $\mathrm{CC}$ chemokines in monocytes: implications for transendothelial chemotaxis. I Gelf Biol 1996; 134: 1063-1073.

276. Schecter AD, Rollins BJ, Zhang YJ, Charo IF, Fallon JT, Rossikhina M, Giesen PLA, Nemerson Y, Taubman MB: Tissue factor is induced by monocyte chemoattractant protein- 1 in human aortic smooth muscle and THP. 1 cells. J Biol Chem 1997:272:28568-28573.

277. Raines EW. Dower SK, Ross R: Interleukin-1 mitogenic activity for fibroblasts and smooth muscle cells is due to PDGF-AA. Science 1989;243:393-396.

278. Libby P. Warner SJC, Salomon PN, Birinyi LK: Production of platelet-derived growth factor-like mitogen by smooth-muscle cells from human atherona. N Engl J Med 1988; $18: 1493-1498$

279. Brogi E, Winkles JA, Underwood R, Clinton SK, Alberts GF, Libby P. Distinct patterns of expression of fibroblast growth factors and their receptors in human atheroma and nonatherosclerotic plaques. J Clin hivest 1993,922408-2418

280. Amento EP, Ehsani N, Paimer H, Libby P: Cytokines and growth factors positively and negatively regulate interstitial collagen gene expression in human vascular smooth muscle cells. Arterioscler Thromb 1991:11:1223-1230.

281. Shi $Y$, O'Brien JE, Fard A, Zalewski A: Transforming growth factor- $\beta 1$ expression and myofibroblast formation during arterial repair. Arterioscler Thromb Wasc Biol 1996; 16:1298-1305.

282. Galis ZS, Muszynski M, Sukhova G, Simon-Morrissey E, Unemori EN, Lark MW, Amento E, Libby P: Cytokine-stimulated human vascular smooth muscle cells synthesize a complement of enzymes required for extracellular matrix digestion. Circ Res 1994;75:181-189.

283. Sporn MB, Roberts $A B$. Waketield $L M$, de Crombrugghe $B$ : Some recent advanced in the chemistry and biology of transforming growth factor-beta. ICell Biol 1987; 105: 1039-1045.

284. Mach F, Schönbeck U, Sukhova GK, Bourcier T, Bonnefoy JY, Pober JS, Libby P: Functional CD40 ligand is expressed on human vascular endothelial cells, smooth muscle cells, and macrophages: Implications for CD40-CD40 ligand signaling in atherasclerosis. Proc Natl Acad Sol U S A $1997: 94: 1931-1936$.

285. Mach F. Schönbeck U. Sukkhova GK, Atkinson E. Libby P: Reduction of atherosclerosis in mice by inhibition of CD40 signalling. Nature 1998;394:200-203.

286. Henn V. Slupsky JP, Grafe M. Anagnostopoulas I. Forster R. Muller-Berghaus G, Kroczek RA: CO40 ligand on activated platelets triggers an inflammatory reaction of endothelial cells. Nature $1998 ; 391: 591-594$.

287. Schönbeck U. Mach F, Sukhova GK, Murphy C, Bonneloy JY. Fabunmi RP, Libby P. Regulation of matrix metalloproteinase expression in human vascular smooth muscle cells by T-lymphocytes. $A$ role for CD40 signaling in plaque rupture? Circ Res 1997:81:448-454.

288. Mach F. Schönbeck U. Bonnefoy JY. Pober JS. Libby P. Activation of monocyte/macrophage functions related to acute atheroma complication by ligation of CD40. Induction of collagenase. stromelysin, and tissue factor. Circulation 1997;96:396-399.

289. Zhou X. Stemme S. Hansson GK: Evidence for a lacal immune response in atherosclerosis. CD4t. T cells infiltrate lesions of apolipoprotein-E-deficient mice. Am I Pathol 1996;149:359-366.

290. Schonbeck U. Mach F. Sukhova GK, Herman M, Graber P. Kehry MR. Libby P: CD40 ligation induces tissue factor expression in human vascular smooth muscle cells. Am J Patho/ 2000; 156:714.

291. Henn V "Slupsky JR, Grafe M. Anagnostopoulos 1. Forster R, Muller-Berghaus G, Kroczek PA: CD40 ligand on activated platelets triggers an inflammatory reaction of endothelial cells. Nature $1998 ; 391: 591-594$ 


\section{Chapter 1}

292. Libby P, Mach F, Schonbeck U. Bourcier T, Akawa M: Regulation of the thrombotic potential of atheroma. Thromb Haem 1999:82:736-741.

293. van den Hoogern PCW, Feskens EJM, Nagelkerke NJD, Menotti A, Nissinen A. Kromhout D: The relation between blood pressure and mortalify due to coronary heart disease among men in different parts of the world. N Engl J Med 2000; 342:1-8. 


\section{Chapter 2}

Atherosclerosis in $\mathrm{ApoE}^{\star} 3$ Leiden transgenic mice: from proliferative to atheromatous stage

Esther Lutgens, Mat Daemen, Mark Kockx, Pieter Doevendans, Marten Hofker, Louis Havekes, Hein Wellens and Ebo de Muinck

Circulation 1999;99:276-283

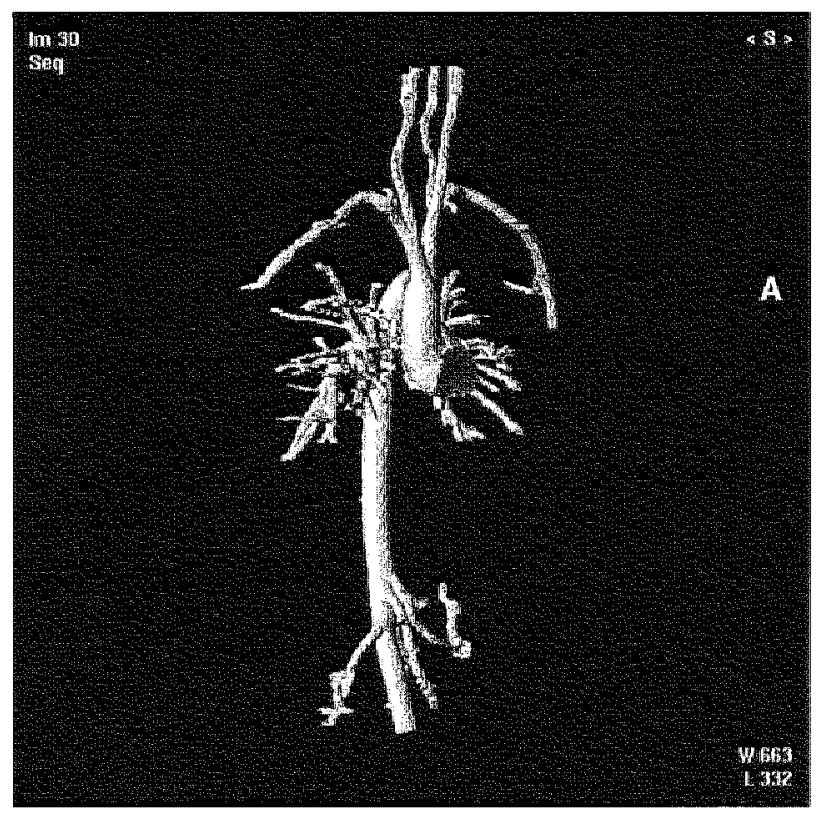




\section{Abstract}

This study documents (1) the progression of atherosclerosis along the entire arterial tree in ApoE*3Leiden mice after 1, 4, 6, 9, and 12 months of a high-fathighcholesterol (HFC) diet and (2) the amount and phenotype of DNA-synthesizing and apoptotic cells in different lesion types after 6 months of HFC diet. Diet duration was correlated with a craniocaudal progression of lesion development and with an increase in severity of the lesion. Typically, the lesions contained smooth muscle cells, macrophages, and $T$ lymphocytes and were covered by an intact endothelium. Whereas DNA synthesis (BrdU uptake) was predominantly elevated in type II lesions ( $8.6 \pm 0.8 \%$ versus $1.0 \pm 0.2 \%$ in the non-diseased arterial wall; $p<0.05)$, apoptosis was found primarily in advanced lesions (type IV, $1.3 \pm 0.1 \%$ and type $V$, $1.2 \pm 0.2 \%$ versus $0.04 \pm 0.04 \%$ in the non-diseased arterial wall; $p<0.05$ ). Cell phenotyping revealed that the majority of DNA synthesis and apoptosis was confined to the macrophage derived foam cell $(68.6 \pm 3.0 \%$ and $82.2 \pm 4.6 \%$, respectively).

This study shows that in ApoE*3Leiden mice, duration of an HFC diet is associated with (1) a craniocaudal progression of lesion development and (2) an increased complexity of atherosclerotic lesions. Furthermore. DNA synthesis is predominant in early lesions, whereas apoptosis is present mainly in more advanced lesions. Both parameters of cell turnover are confined primarily to the macrophage derived foam cell. 


\section{Introduction}

One of the mutant apoe genes that is associated with familal dysbetalipoproteinemia in humans is the ApoE*3Leiden gene. ${ }^{12}$ To evaluate the phenolype in more detail, this gene has been introduced in mice, the ApoE* 3 Leiden mouse. ${ }^{34}$ The data published so far show that ApoE"3Leiden mice exhibit severe hypercholesterolemia when they are fed a high-fathigh-cholesterol (HFC) diet. However, atherosclerosis in these mice has been described only after relatively short periods of cholesteral feeding. $3,5,6$ To date, no detailed description of lesion morphology including data on cell turnover is available. Also data on the progression of lesions along the entire arterial tree and long-term observations on the progression of plaque extent and complexity are lacking. This study was initiated to provide these data.

Methods

Mice

Transgenic mice expressing the human ApoE`3Leiden gene were generated and bred with C57Bl/6J females as described earlier." For the present study, 33 male and 27 femalle mice of the F10 generation were used.

\section{Diet}

Before entry into the study, animals were kept on standard mouse chow (SRM-A, Hope Farms). At the age of $37 \pm 0.6$ weeks (meantSEM), the animals were pult on a diet containing $15 \%$ cacao butter, $0.5 \%$ cholate, $1 \%$ cholesterol, $40.5 \%$ sucrose, $10 \%$ corn starch, $1 \%$ corn oil, and $4.7 \%$ cellulose (Hope Farms) for $1(n=4), 4$ $(n=9), 6 \quad(n=12), 9(m=12)$, and $12(n=12)$ months. Control ApoE ${ }^{\star 3 L e i d e n}(n=6)$ and C57B//6J $(n=6)$ mice received standard mouse chow for 9 months. To label DNAsynthesizing cells 6 transgenic animals of the 6-month diet group received 5'bromo-2'-deoxyuridine (BrdU, Serva; infusion rate, $13 \mathrm{mg}^{*} \mathrm{~kg}^{-1 *} \mathrm{~d}^{-1}$ ) by an osmotic minipump (Alzet 2001. Alza Corp) for the 7 days before they were euthanized. Pumps were placed subcutaneously between the shoulder blades under ether anesthesia. All mice were housed under standard conditions. The study was approved by the institutional committee for the welfare of laboratory animals of the University of Maastricht.

\section{Tissue Handing}

After completion of the diet according to protocol each mouse was anesthetized with xylazine $0.0025 \mathrm{ml} / \mathrm{g}$ and ketamine $0.001 \mathrm{ml} / \mathrm{g}$ ip. Blood $(0.5$ to $1 \mathrm{ml}$ ) was collected from the caval vein for the assessment of lipid profile, and the arterial tree was perfused with $0.9 \% \mathrm{NaCl}$ ( 3 mimutes) and $10 \%$ phosphate-buffered formalin (pH $7.4,3$ minutes), both containing $20 \%$ nitroglycerin, through a catheter into the lett ventricular apex. Subsequently, the complete arterial tree was taken out and fixed overnight in $10 \%$ phosphate-buffered formalin. All arterial segments indicated in fig. 1 were processed and embedded in paraffin, and $4 \mu \mathrm{m}$ sections were stained with hematoxylin and eosin. Atherosclerotic lesions were classified according to the 
guidelines given by the American Heart Association (AHA) by 1 investigator (E.L.), who was blinded to presence or absence as well as duration of diet and to genotype.

\section{Assessment of Lipid Profile}

Total serum cholesterol and triglycerides (but not free glycerol) were measured as described previously. ${ }^{3}$

\section{Immunohistochemistry}

\section{Study 1: Diet-Dependent Lesion Progression}

Because of its size and because all lesion types also developed in the aortic arch, we concentrated the immunohistochemical analyses on this segment. Parallel sections of the aortic arch were immunolabeled with either ED- $1^{9}$ for the detection of macrophage derived foam cells, CD-3 (CD-3, polyclonal, 1:200, Dako A0452) for the detection of Tulymphocytes, $\alpha$-smooth muscle actin (monoclonal, 1:500, FITClabeled, Sigma Chemical Co) or desmin (monoclonal, 1:100, Organon MDEli, Eurodiagnostics) as smooth muscle cell markers, or factor VIII (polyclonal, 1:2000, Dako A0082) for the detection of endothelial cells. Immunostaining was performed according to conventional methods with biotin- or FITC- ( $\alpha$-smooth muscle actin) labeled secondary antibodies and 3,3'-diaminobenzidine (DAB) as a chromogen. Sections were counterstained with hematoxylin and mounted with coverslips. In all immunohistochemistry, sections treated without the respective primary antibody served as controls.

\section{Study 2: Cell Turnover in Atherosclerotic Lesions}

\section{BrdU Staining.}

After dehydration, the sections were incubated for 2 hours in 3\% EDTA (Merck) at $\mathrm{pH} 7.2$ to block nonspecific staining of calcium-containing vesicles. ${ }^{10}$ BrdU staining was performed as described previously ${ }^{11}$, with $\mathrm{DAB}$ as the chromogen.

\section{TUNEL Staining}

Parallel sections were used for the TUNEL staining. After dehydration, sections were incubated with $3 \%$ citric acid to inhibit aspecific binding of the nucleotides to calcium-containing vesicles. TUNEL staining was performed as described previously. ${ }^{10}$ Amino-3-9-ethylcarbazole (AEC) was used as chromogen. Sections were counterstained with hematoxylin and mounted with coverslips. Negative controls included omission of TdT from the labeling mixture. Tonsils were used as a positive control.

\section{Cell Phenotypes}

Parallel sections of atherosclerotic lesions of the 6 APOE*3-Leiden mice were immunolabeled with ED-1, $\alpha$-smooth muscle actin, CD-3, and factor VIII as described above. 


\section{Cell Counting}

Tissue sections were investigated by light microscopy at ${ }^{*} 400$ magnification with a standard field size. All nuclei of the respective lesion type were counted. Cells containing dark nuclear BrdU staining were considered to be DNA-synthesizing cells. Apoptotic nuclei were defined as TUNEL-positive nuclei in cells that showed morphological features of apoptotic cell death (cell shrinkage, aggregation of chromatin into dense masses, cell fragmentation ${ }^{12}$ The labeling index, defined as the total number of positive cells divided by the total number of cells, was calculated for the entire atherosclerotic lesion, including the underlying media. This was performed separately for the BrdU- and TUNEL-stained sections. Labeling indices were also determined in different sites of the lesion: the underlying media, the endothelial coverage, the shoulder region, the lipid core, and the fibrous cap. Furthermore, the distribution of the different immunophenotypes of BrdU- or TUNELpositive cells was quantified. The immunophenotype of $89.1 \pm 1.4 \%$ of the DNAsynthesizing cells and $97.3 \pm 2.2 \%$ of the apoptotic cells could be determined by the above-described panel of antibodies (CD3, ASMA, FVIII, ED-1). All measurements were performed by 1 investigator (E.L.). Intraobserver variation was $<10 \%$.

\section{Statistical Analysis}

\section{Study 1: Diet-Dependent Lesion Progression}

Data are expressed as mean \pm SEM or as median values (AHA classification). All experimental groups were compared with the ApoE*3Leiden mice on normal chow. Atherosclerotic lesions of male and female mice in the different diet groups were compared by a non-parametric Mann-Whitney $U$ test. Because no significance was found, atherosclerotic lesions of male and female mice were pooled. Cholesterol, triglyceride, and apoE levels were analyzed by the Kruskal-Wallis test, and Student's t-test was used for comparisons between the groups.

\section{Study 2: Cell Turnover in Atherosclerotic Lesions}

Data are expressed as meantSEM. To test whether lesions of the same type in different mice and lesions of the same type at different sites of the arterial tree were comparable, a 1-way ANOVA was performed on both parameters.

This was performed for both BrdU- and TUNEL-stained sections. Because no significant difference was found, lesions of the different mice and at the different sites of the arterial tree were assumed to be comparable. Subsequently, a MannWhitney $U$ test was used for comparisons between the lesion types. In all tests, the level of statistical significance was assumed to be at $p<0.05$. 


\section{Results}

\section{Study 1: Diet-Dependent Lesion Progression}

\section{Cholesterol, Triglyceride, and ApoE Levels}

In the ApoE* 3 Leiden mice on the HFC diet, all values except triglyceride levels after 1 month of HFC diet were significantly higher than in both control groups $(p<0.05)$ (table 2.1). Human apoE plasma levels were elevated in all transgenic animals, confirming the expression of the ApoE*3Leiden gene.

Table 1

Cholesterol, Triglyceride and human ApoE levels iri ApoE*3Leiden mice and C57B!6 mice.

\begin{tabular}{|c|c|c|c|}
\hline & $\begin{array}{l}\text { Cholesterol } \\
\text { (mmoll/) }\end{array}$ & $\begin{array}{l}\text { Triglycerides } \\
(\mathrm{mmal} / \mathrm{l})\end{array}$ & Human ApoE $(g / l)$ \\
\hline ApoE $3,1 \mathrm{~m}$ HFC $(n=4)$ & $18.4 \pm 1.4^{*}$ & $0.4 \pm 0.1$ & $0.4 \pm 0.06^{*}$ \\
\hline ApoE*3, $6 \mathrm{mHFC}(n=12)$ & $38.5 \pm 5.3^{*}$ & $2.3 \pm 0.2^{*}$ & $0.9 \pm 0.11^{*}$ \\
\hline ApoE $* 3,9 m$ HFC $(n=12)$ & $43.8 \pm 5.8^{*}$ & $2.0 \pm 0.3^{*}$ & $1.0 \pm 0.10^{*}$ \\
\hline ApoE $3,12 m$ HFC $(n=12)$ & $30.6 \pm 3.9^{*}$ & $2.4 \pm 0.3^{*}$ & $0.7 \pm 0.08^{*}$ \\
\hline ApoE $3,9 m N C(n=6)$ & $1.3 \pm 0.03 *$ & $0.2 \pm 0.05$ & $0.1 \pm 0.06$ \\
\hline C57B1/6, $9 \mathrm{~m} N \mathrm{NC}(n=6)$ & $0.8 \pm 0.11^{*}$ & $0.1 \pm 0.04$ & $0.0 \pm 0.00$ \\
\hline
\end{tabular}

Values are meantSEM. ApoE*3 indicates ApoE*3-Leiden transgenic mice; C57Bl/6J indicates C57Bl6.J (wildtype) mice; m. months; HFC, high fat cholesterol diel; NC, nomal chow. $p<0.05$ vs ApoE*3Leiden mice on normal chow.

\section{Atherosclerotic Lesions in ApoE*3Leiden Transgenic Mice}

Atherosclerotic lesions developed in the aorta and large vessels in all ApoE*3Leiden mice on an HFC diet (fig. 2.1). Lesions developed in the proximal coronary arteries (fig. 2.2a), the aortic root, the aortic arch and its main branch points (fig. 2.2b), the thoracic aorta, the abdominal aorta, the renal artery branch points (fig. 2.2c), the abdominal aorta bifurcation, and the iliac artery bifurcations. Almost all lesion types were observed: initial lesions with isclated macrophage foam cells (type 1), fatty streaks with mainly intracellular lipid accumulation (type II, fig. 2.3a), and intermediate lesions with type II changes and smallextracellular lipid pools (type III). Also, more advanced lesions could be detected, such as an atheroma with type II changes and a core of extracellular lipid (type $\mathrm{N}$, figs. $2.2 \mathrm{~b}$ and $2.3 \mathrm{~d}$ ) as well as fibroatheromata with a lipid core and a fibrotic layer (figs. 2.2a and 2.2c), or with multiple lipid cores and fibrotic layers (type $\mathrm{Va}$ ), or mainly calcific (type Vb, figs. $2.2 \mathrm{~d}$ and $2.3 \mathrm{e}$ ) or fibrotic (type $\mathrm{Vc}$ ) fibroatheromata. Type $\mathrm{VI}$ lesions with plaque rupture, thrombus formation, and hemorrhage were not observed.

In the ApoE*3Leiden mice on normal chow, only initial typel and II lesions were observed. Wild-type mice on normal chow did not developatherosclerosis.

\section{Immunophenotype}

Macrophages were not present in the normal media but were found in the media and intima of all lesion types (fig. 2.3a). In advanced lesion types, lipid-filled macrophages were present primarily in the shoulder region of the lesion. Tlymphocytes were present primarily in advanced lesion types (IV to Vb), especially in the shoulder region and fibrous cap (fig. 2.3b). 

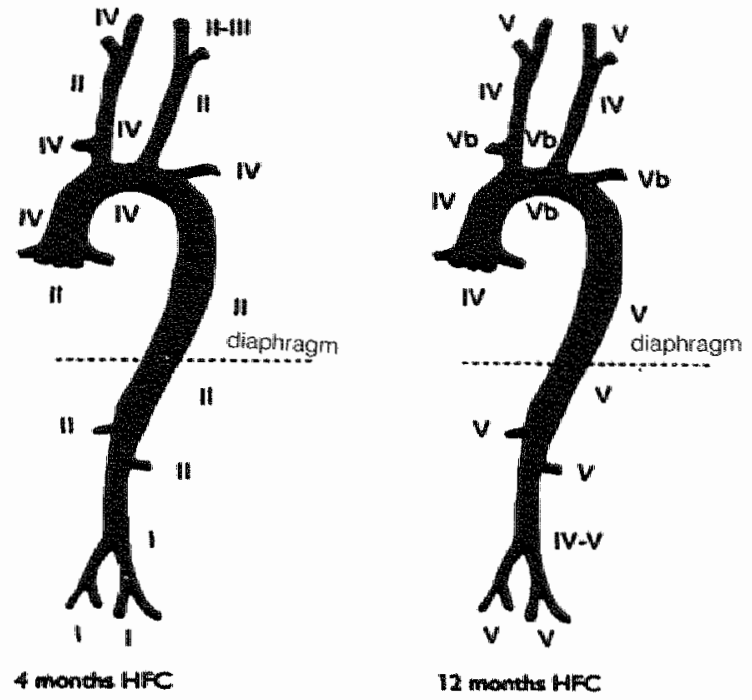

Fig. 2.1

Progression of apherosclerosis along the entire arterial tree after 4 and 12 months of HFC diet in ApoE*3Leiden mice.

Both the media of non-diseased vessel segments and the non-diseased media below an atherosclerotic lesion showed no desmin-positive vascular smooth muscle cells (VSMCs) (fig. 2.3c and 2.3d). However, desmin-positive VSMCs were present in the intima and fibrous cap of advanced lesions (fig. 2.3d). All atherosclerotic lesions contained $\alpha$-smooth muscle actin positive VSMCs, both in the non-diseased media below the lesion and in the lesion itself (fig. 2.3e). They were most numerous in the fibrous cap of advanced lesion types. The endothelial coverage of the lesions remained intact, even in very advanced lesions (fig $2.3 \mathrm{f}$ ).

\section{Effect of Diet Duration on Lesion Progression}

The variability in the development of atherosclerotic lesions between mice in 1 diet group was remarkably low and diet duration seemed to predict lesion lype and site (data not shown). Aiter 1 month of HFC diet, initial type II lesions were observed only in the aortic root, the aortic arch and its main branches, the carolid artery bifurcations, and the thoracic aorta. Below the diaphragm, no lesions were observed.

After 4 months of HFC diet, initial type $\|$ lesions were present in the coronary arteries. Advanced atherosclerotic lesions (type IV) with a core of extracellular lipid were present in the aortic root, the aortic arch and its main branchpoinis, and the right carotid artery bifurcation. Below the diaphragm, only initial lesions (type land II) with foam cells in the subendothelium were observed (fig. 2.1). 
A
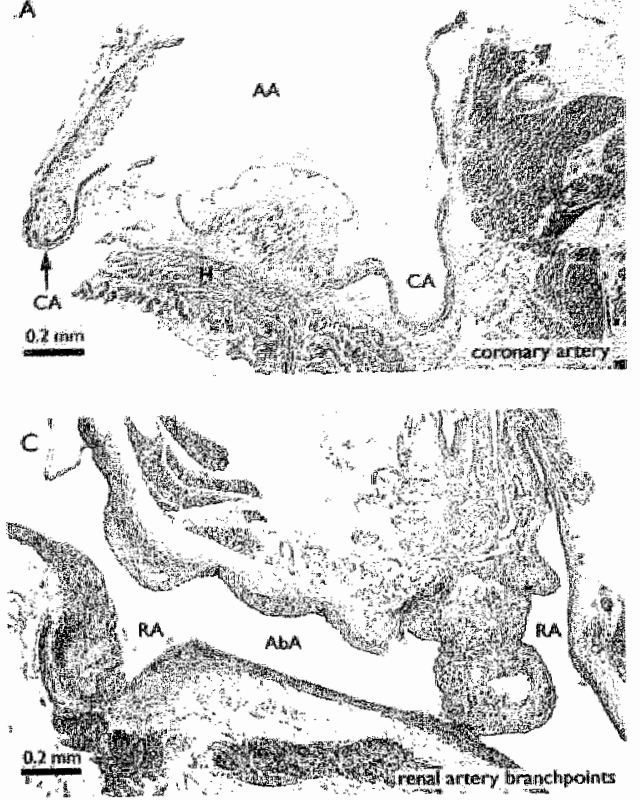

$B$
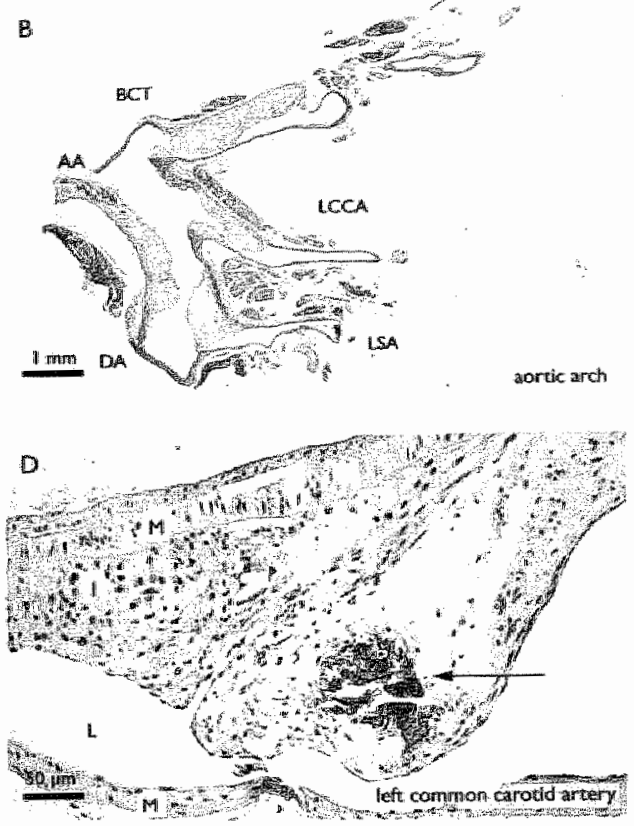

Fig. 2.2

Photomicrographs of haematoxilin and eosin stained sections. A, Ascending aorta (AA); Heart (H); and coronary artery (CA). B. Ascending (AA) and descending (DA) aorta; brachiocephalic trunk (BCT); left common carctid artery (LCCA); and left subclavian artery (LSA). C. Abolominal aorta (AbA); renal artery (RA). D. Calcified core (arrow); lumen (L) of left common carotid artery: media (M); and intima (I).

After 6 months of HFC, advanced type IV lesions had developed in the coronary arteries (fig. 2.2a). Furthermore, type $V$ lesions with a fibrous cap and a lipid core were present in the aortic arch and its main branches (fig. 2.2b). Type IV lesions had also developed in the abdominal aorta and renal artery branch points.

After a diet period of 9 months, severe calcification of the atherosclerotic lesions (type $\mathrm{Vb}$ ) was observed in the aartic arch and its main branch points (fig. 2.2d). Type $V$ lesions were present in the right carotid artery bifurcation. Type IV lesions had developed in the thoracic aorta, in the abdominal aorta, and at the renal artery branch points. However, in the abdominal aorta and the iliac arterybifurcations, only type Il lesions could be observed.

After 12 months of HFC diet, lesions in the aortic arch showed calcification (type $\mathrm{Vb}$ ), and type $\mathrm{V}$ lesions were observed at both the right and left carotid artery bifurcations. Moreover, 5 of 12 mice showed calcifications in their coronary arteries. Furthermore, at the abdominal aorta bifurcation and the illac artery bifurcations, advanced lesions (type IV) had developed (fig. 2.1). 

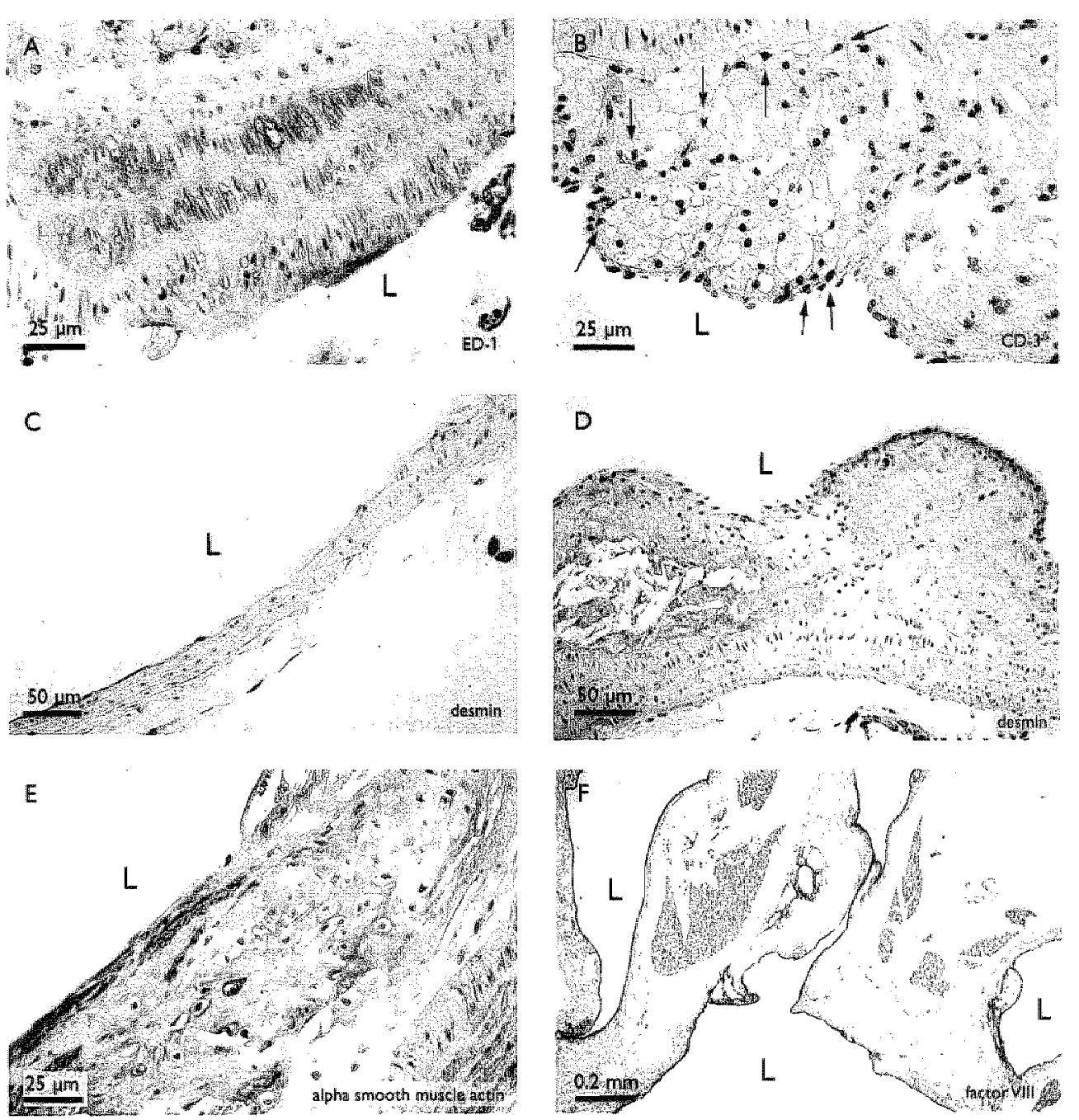

Fig. 2.3

Immunohistochemistry of atherosclerotic lesions in ApoE*3Leiden mice with different antibodies. $A$, ED-1; B. CD3: C desmin; D, desmin; E. ASMA; F, faclor VIll. L indicates lumen. 


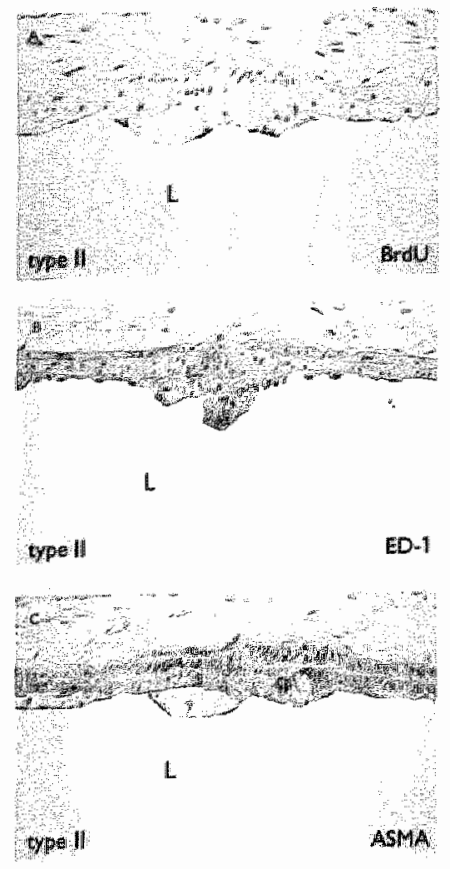

Fig. $2.4 \mathrm{~A}-\mathrm{C}$

Photomicrographs showing subsequent immunolabeling of a type II lesion (Brou staining, ED-1 and ASMA).
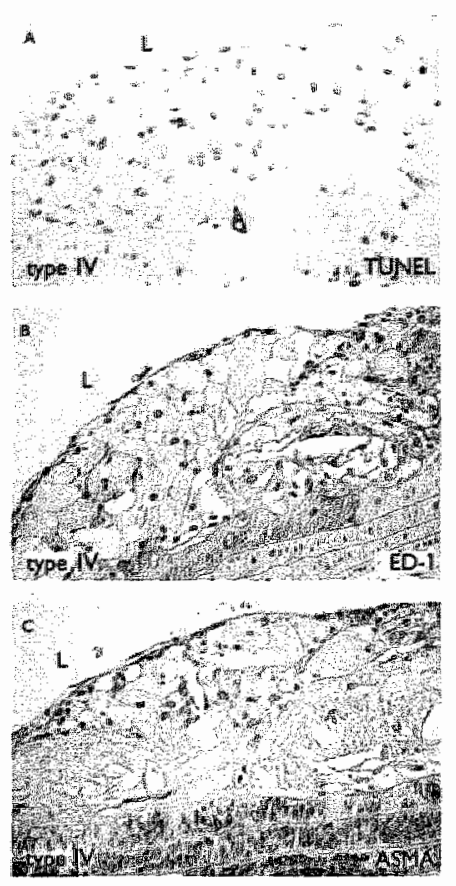

Fig. 2.5 A-C

Photomicrograpihs showing subsequent immunolabeling of a type IN lesion (TUNEL. ED-1 and ASMAI.

Study 2: Cell Turnover in Atherosclerotic Lesions

In total. 135 lesions were investigated throughout the arterial tree of the 6 Apof* 3 Leiden mice fed an HFC diet for 6 months. BrdU-and TUNEL-positive nuclei were counled in all lesion types except in type l lesions, because the total number of nuclei in this lesion type was too small. Thirty non-diseased arterial segments served as controls.

\section{DNA Synthesis}

In all lesion types, DNA synthesis was significantly elevated compared with the nondiseased arterial wall (fig. 2.4). The highest BrdU labeling was found in type II (fatty streak) lesions $(8.6 \pm 0.8 \%$ versus $1.0 \pm 0.2 \%$ in the non-diseased arterial wall; $p<0.05$ ) (fig. 2.4a). With progression of severity of the lesion, DNA synthesis decreased to $5.8 \pm 0.7 \%$ in complex type $V$ lesions ( $P<0.05$ versus type 11 ).

Not only the level but also the site of DNA synthesis changed with progression of the lesion (fig. 2.4d). In type ll lesions, most DNA-synthesizing cells were found in the media ( $77.9 \%$ of all DNA-synthesizing cells), whereas in type $11 \mathrm{I}$, IV, and $\mathrm{V}$ lesions, only a small amount of DNA-synthesizing cells was found in the media $(17.1 \%, 14.1 \%$, and $12.1 \%$, respectively; $<0.05)$. With the development of a 
shoulder region in iype III and IV lesions. DNA synthesis shifted to that region (32.9\% and $41.0 \%$ of all DNA-synthesizing cells, respectively) as well as to the endothelial cells covering the lesion (30.0\% and $32.1 \%$, respectively). The percentage of DNA synthesis of endothelial cells covering type 111 and IV lesions, was significantly increased compared with both type II lesions and the nondiseased arterial wall $(p<0.05)$. When atherosclerosis had progressed to advanced type $\mathrm{V}$ lesions with a fibrous cap and a lipid core. DNA-synthesizing cells were located in the shoulder region (36.2\%) and fibrous cap (29.3\%), whereas the fraction of DNA-synthesizing cells of endothelial cells covering the fibrous cap showed a significant decrease to $12.1 \%$ compared with type IV lesions $(p<0.05)$. DNA synthesis in the lipid core of type IV and V lesions was low $(12.8 \%$ and $12.1 \%$ of all DNA-synthesizing cells, respectively).

Subsequent immunolabeling (fig. 2.4) showed that $68.6 \pm 3.0 \%$ of the DNA. synthesizing cells were macrophage derived foam cells, $14.5 \pm 2.5 \%$ VSMCs, $1.3 \pm 0.3 \%$ T-lymphocytes, and $5.3 \pm 1.2 \%$ endothelial cells of the endothelial coverage. In all lesion types, the majority of DNA-synthesizing cells were macrophage derived foam cells, but the ratio of macrophage derived foam cells to VSMCs decreased with lesion development. In early type II lesions, this ratio was 76.9 , whereas in complex type $V$ lesions, this ratio had decreased to $3.7(p<0.05)$.

\section{Apoptosis}

The distribution of apoptotic nuclei in the different lesion types differed from the distribution of DNA-synthesizing nuclei (fig. 2.5). In type II and III lesions, the apoptotic labeling index was not different from the apoptotic labeling index in the non-diseased arterial wall. The percentage of apoptotic nuclei was elevated only in type IV and $V$ lesions $(1.3 \pm 0.1 \%$ in type $\mathrm{IV}$ and $1.2 \pm 0.2 \%$ in type $V$ versus $0.04 \pm 0.04 \%$ in the non-diseased arterial wall). The majority of apoptotic nuclei was located in the lipid core of these type IV and $V$ lesions $(81.9 \%$ and $79.5 \%$ of all apoptotic cells, respectively). Furthermore, onlly low levels of apoptosis were found in the fibrous cap ( $9.0 \%$ of all apoptotic cells).

Cell phenotyping revealed that the majority of apoptosis was confined to the macrophage-derived foam cells $(82.2 \pm 4.6 \%$ ) (tig. 2.5 ). Apoptosis in other cell types was rarely observed. 


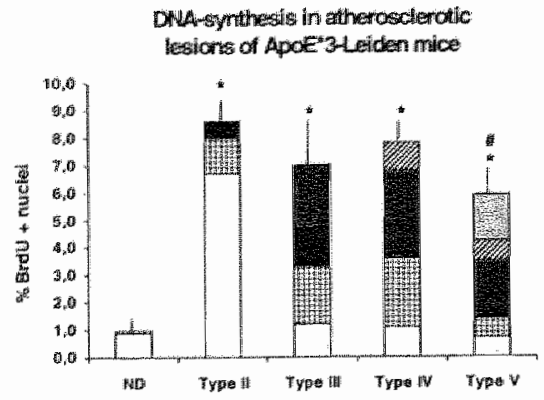

Apoptosis in athercosdenctic lesions d ApoezLiden mice

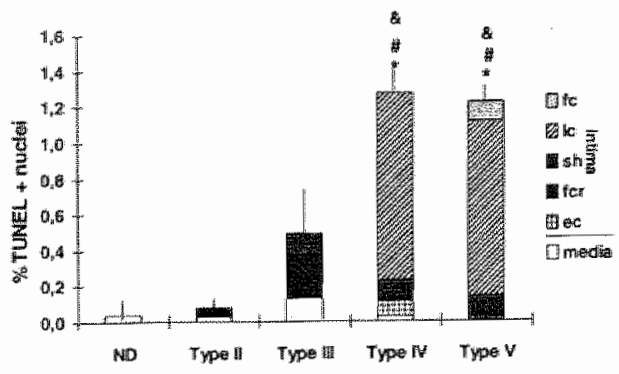

Phenotype of DNA-synthesizing cells

Phenotype of apoptotic cells
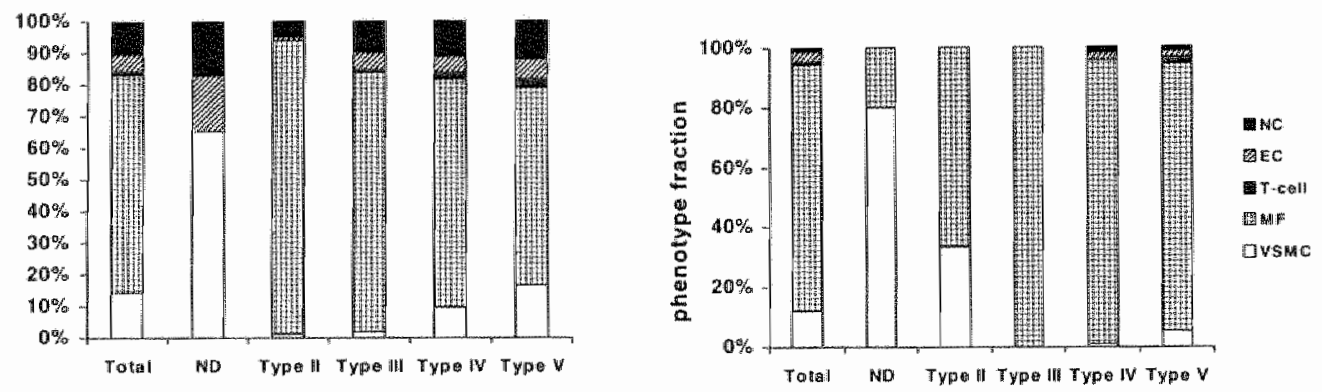

Fig. 2.4 D-E (left)

D. Level and distribution of DNA-synthesizing cells in atherosclerotic lesion types. Ec indicates endothelial coverage; tor, foam cell-rich area; sh, shoulder region; Ic. lipid core; and fo, fibrous cap. "p<0.05 ws non-diseased (ND). \#P<0.05 vs type II. E, Phenolypical distribution of DNA-synthesizing cells in atherosclerotic lesion types. MF indicates macrophage, $\mathbb{E C}$, endothellal cell; and $N C$, not classified.

Fig. 25 D-E (right)

D. Level and distribution of apoptotic cells in atherosclerotic lesion lypes. $p<0.05$ vs ND, 部< 0.05 vs type II, \&p<0.05 vs type III. E. Fhenotypical distribution of apoptotic cells in atherosclerotic lesion types. Abbreviations as in fig. 2.4. 


\section{Discussion}

One of the most important steps in atherogenesis is the transition of a fatty streak into an atherosclerotic plaque. In the present study, it was demonstrated that fatty streaks were characterized by DNA synthesis with no detectable apoptosis. These lesions progress toward atheroscleratic plaques, which were characterized by the presence of both DNA synthesis and apoptosis. This finding is comparable to the classic studies of Virchow, who described atherosclerosis as a formative process. starting with "proliferation" and terminating with "fatty degeneration." 13

So far, few human data on DNA synthesis during the entire process of atherogenesis are available. ${ }^{14}$ Orekhov et al ${ }^{14}$ report peak levels of DNA synthesis in lipid-rich lesions, whereas DNA synthesis in fibrous lesions is much lower. The majority of data on DNA synthesis in human atherosclerosis are confined to advanced lesions only. They show low levels of DNA synthesis $(0 \% \text { to } 2 \%)^{15-18}$ but this level is significantly higher than in the non-diseased arterial wall. ${ }^{14.15,18,19}$ One study on DNA synthesis in early fatty-streak lesions also reports low values of DNA synthesis $(0 \% \text { to } 2 \%)^{20}$ DNA synthesis in these human lesions is confined primarily to either the macrophage-derived foam cell ${ }^{15.17 .18}$ or the VSMC. ${ }^{16}$ As in human in witro studies ${ }^{21}$ and rabbit models ${ }^{22 m 24}$, the ApoE*3Leiden mouse exhibits a DNAsynthesis peak in early lesion types. DNA synthesis in advanced lesion types is low. which is in accordance with the low levels of DNA synthesis found in advanced human atheramata. ${ }^{15-18}$ Interestingly, we observed 2 kinds of lype 11 lesions. "The early type II lesion contained macrophage derived foam cells that were located only in the media, whereas the late type II lesion contained macrophage-derived foam cells in the intima. We defined them as type Ila and IIb, respectively. In the early type lla lesions, DNA synthesis was significantly elevated compared with the late type $\mathrm{ll}$ b lesions( $10.3 \pm 0.8 \%$ in type $\mathrm{lla}$ versus $6.0 \pm 1.3 \%$ in type $\mathrm{lb}$ ). In both lesion types, the majority of DNA-synthesizing cells were macrophage-derived foam cells ( $91.1 \%$ and $94.2 \%$, respectively). The fact that the intima of a non-diseased vessel in the mouse consists of only a very small subendothelial llayer may explain our observation that early lesions contain medial macrophage-derived foam cells, whereas in advanced lesions, these macrophages are present in the intima. Thus, it seems that the firs migrating macrophage derived foam cells are transported from the blood into the most luminal layer of the media. With the accumulation of increased numbers of macrophage derived foam cells (type Ilb through Vb), a neointima develops.

Enhanced rates of apoptotic cell death have also been observed in advanced human atherosclerosis. ${ }^{25-28}$ In a recent study, we found that fatty streak lesions are characterized by very low levels of apoptosis, whereas advanced atherosclerotic lesions showed remarkable levels of cell death. ${ }^{29}$ In human atheromata, the apoptotic labeling index varies from $0 \%$ to $40 \%$, and apoptotic nuclei are present primarily in the lipid core and regions adjacent to the lipid core, but also in the fibrous cap. ${ }^{25,27,28}$ The majority of apoptotic nuclei have been found in macrophages $^{25.27}$ and T- Iymphocytes. ${ }^{26}$ Also, in ApoE*3Leiden mice, apoptosis was confined to the advanced stages, albeit at fairly low levels. Moreover, apoptosis in the fibrous cap was a rare phenomenon. Whether this phenomenon can be an 
explanation for the apparent plaque stability obserwed in these mice remains to be investigated.

One of the major differences of atherosclenosis in the Apo E*3Leiden mouse with human atherosclerosis is the absence of plaque rupture, thrombus formation, andior hemorrhage in the atherosclerotic plaque. ${ }^{30}$ We have no explanation for the apparent stability of the atherosclerotic plaques in the ApoE*3Leiden mouse. One of the possibilities is that the morphologically intact endothelial layer that covers all lesion types in the ApoE*3Leiden mouse prevents lesions from rupturing. Another explanation is the low level of apoptosis in the fibrous cap in these mice.

The data presented here may have clinical implications. It is known that treatment with HMG-CoA reductase inhibitors can slow the progression of atherosclerosis. "One of the mechanisms that have been diescribed is the inhibition of DNA synthesis in both VSMCS and macrophages. ${ }^{32.33}$ Our data imply that these agents may be most successful in slowing the progression of atherosclerosis when they are applied early in the disease process, when DNA synthesis is mostly elevated. Conversely, it may be more interesting to look at agents that modulate apoptosis. Because apoptosis is a late event in atherogenesis, inhibition of apoptosis may both slow the progression of atherosclerosis and be effective in preventing the conversion from stable into unstable atherosclerotic lesions.

In the present article, we demonstrate that ApoE*3Leiden mice show a highly reproducible diet-and time-dependent cranio-caudal progression of atherosclerosis extent and plaque complexity. We found a peak in DNA synthesis in early lesions and a peak in apoptosis in late lesions, which are both confined to macrophage derived foam cells. Diet dependency, predilection site, plaque composition, and cell turnover make the ApoE*3Leiden mouse a suitable model to study different aspects of early atherogenesis and the evaluation of pharmacological and nonpharmacological interventions.

\section{Acknowledgment}

This study was supported by a grant from the Wynand Pon Foundation, Leusden, Netherlands

\section{References}

1. de Knijf P, van den Maagdenberg AM, Stalenhoef AF, Leuven JA, Demacker PN. Kuyt LP. Frants RR. Havekes LM: Familial dysbetalipoprotememia associated with apolipoprotein E3Lelden in an extended multigeneration pedigree. J Clin hvest 1991,88:643-655

2. Van den Maagdenberg AMUM, de Kniff P. Stalenhoef AFH, Leuven JA, Havekes LM, Frants RR: Apolipoprotein E3-Leiden allele results from a partial gene duplication in exon 4 . Biochem Biophys Res Commun 1989;165:851-857.

3. van Vhimen BJ, van den Maagdenberg AM, Gibels MJ, vam der Boom Hi, HogenEsch H, Frants AP. Hoker MH, Havekes LM: Diet-induced hyperlipoproteinemia and atherosclerosis in apolipoprotein E3-Leiden transgenic mice. J Chin Invest $\$ 994: 93: 1403-1410$

4. Van den Maagdenberg AM, Hoker MH, Krimpenfort PJ, de Bruin I, van Vlijmen B, van der Boom H. Havekes LM, Framls RR: Transgenic mice carying the apolipoprotein E3. Leiden gene exhibit hyperlipoprateinemia. J Brol Chem 1993;268:10540-10545. 
5. Groof PH, van Wijmen BJ, Bensan GM, Hoker MH. Schiffelers R, Vidgeon Hart M, Havekes LM: Quantitative assessment of aortic atherosclerosis in APOE 3 Leiden transgenic mice and its relationship to serum cholesterol exposure. Anterioscler Thromb Vasc Biol 1996:16:926-933.

6. Leppänen P. Luoma ${ }^{S}$. Hofker MH. Havekes LM. Ylä-Hertuala S: Characterization of atheroscierotic lesions in apo E3-Leiden transgenic mice. Atheroscterosis 1998:136:147-152.

7. Nishina PM. Verstuylt J. Paigen B: Synthetic low and high fat diets for the study of atherosclerosis in the mouse. JLipid Res 1990;31:859.869.

8. Stary HC, Chandler AB, Dinsmore RE, Fuster $V$, Glagov S, Insull W Jr, Rosenteld ME. Schwartz CJ. Wagner WD. Wissler RW: A detinition of advanced types of atherosclerotic lesions and a histological classification of atheroscierosis: a report from the Committee on Vascular Lesions of the Council on Arteriosclerosis. American Heart Association. Anterioscler Thromb Vase Bio 1995:15:1512-1531.

9. Dijkstra CD, Dopp EA, Joling P. Kraal G: The heterogeneity of mononuclear phagocyles in lymphoid organs: distinct macrophage subpopulations in the rat recognized by monoclonal antibodies ED1, ED2 and ED3. Immunology 1985:54:589-599.

10. Kockx MM, Muhring J. Bortier H. De-Meyer GR. Jacob W: Biotin- or digoxigenin-conjugated nuclectides bind to matrix vesicles in atherasclerotic plaques. Am J Pathol 1996:148:1771-1777.

11. van Krimpen C. Smits IF. Cleutjens JP, Debets JW. Schoemaker RG. Struyker-Boudier HA, Bosman FT, Daemen MJ: DNA synthesis in the non-intarcted cardiac interstitum after left coronary artery ligation in the rat: effects of captopril. J Mol Cell Cardiol 1991:23:1245-1253.

12. Schwartz SM, Bennett MP: Death by any other name. Am J Pathot 1995; 147:229-234.

13. Virchow A: Die Cellularpathologie: Sechszehnte Vorlesung. 14 April 1858. Hildesheim; Germany: George OIms; 1966:317-329.

14. Orekhov AN, Andreeva ER, Mikhailova IA, Gordon D: Cell proliferation in normal and atherasclerotic human aorta: proliferative splash in lipid-rich lesions. Arteriosclerosis 1998:139:41-48.

15. Rekhter MD, Gordon D: Acive proliferation of different cell types, including lymphocytes, in human atherosclerotic plaques. Am J Pathol 1995; 147:668-677

16. OBrien ER. Apers CE. Stewart DK, Ferguson M, Tran N. Gordon D, Benditt EP. Hinohara T, Simpson JB. Schwartz SM: Proliferation in primary and restenotic coronary atherectomy tissue: implications for antiprolliferative therapy. Circ Res 1993;73:223-231.

17. Gordon D. Reidy MA, Benditt EP, Schwartz SM: Cell proliferation in human coronary arteries. Proc Nall Acad Sci US A 1990:87:4600-4604.

18. Brandl $R$, Richter $T$, Haug K. Wilhelm MG. Maurer PC, Nathrath W: Topographic analysis of proliferative activity in carotid endarterectomy specimens by immunocytochemical delection of the cell cycle-related antigen Ki-67. Circulation 1997:96:3360-3368.

19. Pickering JG. Weir $L$, Jekanowski J, Kearney MA, Isner JM: Proliferative activity in peripheral and coronary atherosclerotic plaque among patients undergoing perculaneous revascularization. I Clin Invest 1993;91:1469-1480.

20. Katsuda $S$, Coltrera MD. Ross R. Gown AM: Human atherosclerosis, IV: immunocytochemical analysis of cell activation and proliferation in lesions of young adults. Am I Pathol 1993:142:1787-1793.

21. Orekhov AN, Kosykh VA, Repin VS, Smimow VN: Cell proliferation in normal and atheroscleratic aorta. II: autoradiographic observation on deoxyribonucleic acid synthesis in primary cell culture. Lab inwes: 1983;48:749-754.

22. Stary HC. McMilan GC: Kinetics of cellular prolifteration in experimental atherosclerosis: radioautography with grain counts in cholesterol-fed rabbits. Arch Pathol 1970,89:173-183.

23. Fosenteld ME Ross A: Macrophage and smooth muscle cell proliferation in atherosclerotic lesions of WHHL and comparably hypercholesterolemic fatted rabbits. Arteriosclerosis $1990 ; 10: 680-687$.

24. Kockx MM, de Meyer GR, Muhring J, Bult H. Buttinck J, Herman AG. Distribution of cell replication and apoptosis in atherosclerotic plaques of cholesterd-fed rabbits. Aherosclerosis $1996 ; 120: 115-124$

25. Geng YJ. Libby P: Evidence for apoptosis in advanced humars atheroma: colocalization with interleukin-1 beta-converting enzyme. Am I Pathol 1995; 147:251-266. 
26. Bjorkerud $\mathrm{S}$. Bjorkerud B: Apoptosis is abundant in human atherosclerotic lesions, especially in infiarmatory cells (macrophages and T-cells), and may contribute to the accumulation of gruel and plaque instability. Am of Pathol 1996; 149:367-380.

27. Han DKM, Haudenschild CCH. Hong MK, Tinkle BT, Leon MB, Liau G. Evidence for apoptosis in human atherogenesis and in a rat wascular injury model. Am J Pathol 1995:147:267-277.

28. Isner JM, Keamey M, Boriman S. Passeri J: Apoptosis in human atherosclerosis and restenosis. Circulation 1995;91:2703 2711.

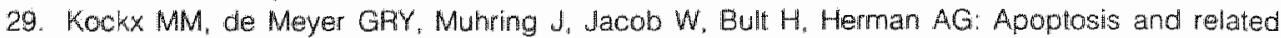
proteins in different stages of human atherosclerotic plaques. Circulation 1998;98:2307-2315

30. Ross R: Cell biology of atherosclerosis. Annu Rev Physiol 1995:57: 791-804.

31. Blankenhorn DH. Azen SP, Kramsch DM, Mack WJ, Cashin Hemphill L, Hodis H. DeBoer LWV. Mahrer PR, Masteller MJ, Vailas LI, Alaupovic A, Hirsch LJ: Coronary angiographic changes with lowastatin therapy. Ann Intern Med 1993; 119:969-976.

32. Martinez-Gonzalez J. Badimon L: Human and porcine smooth muscle cells share similar proflferation dependence on the mevalonate pathway: implication for in wivo interventions in the porcine model. Eur J Clin Invest 1996;26:1023-1032.

33. Spagnoli LG. Orlandi A, Santeusanio G. Foam cells of the rabbit atherosclerotic plaque arrested in metaphase by colchicine show macrophage phenotype. Atherosclerosis 1991:88:87-92. 


\section{Chapter 3}

Biphasic pattern of cell turnover characterizes the progression from fatty streaks to ruptured human atherosclerotic plaques

Esther Lutgens, Ebo de Muinck, Peter Kitslaar, Jan Tordoir, Hein Wellens and Mat Daemen

Cardiovasc Res 1999:41:473-479

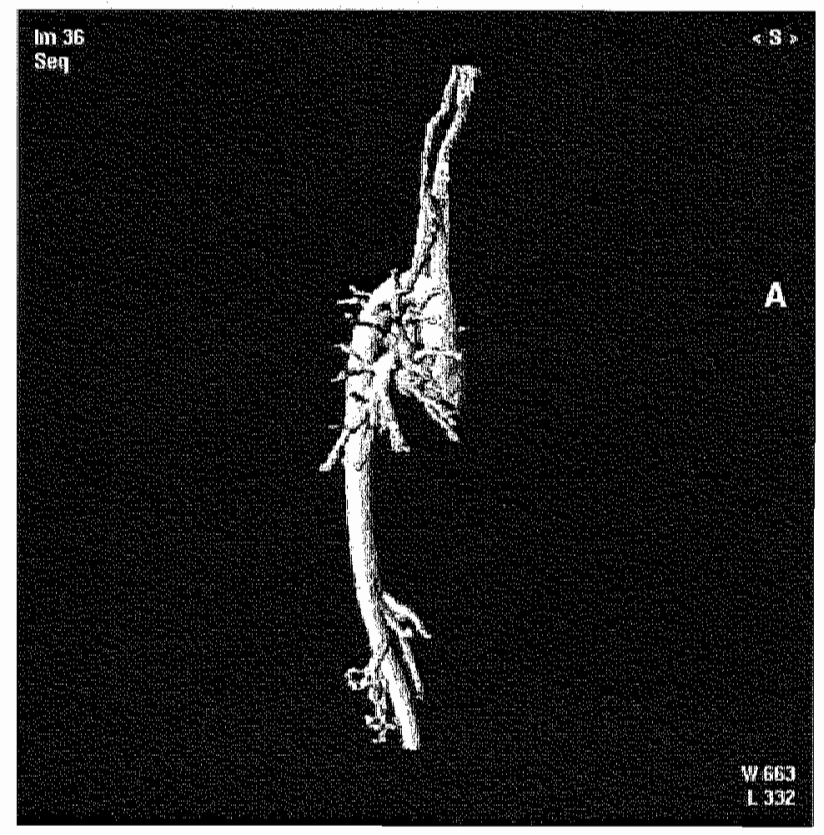




\section{Abstract}

Objective: To study the amount and phenotype of DNA-synthesizing and apoptotic cells during atherogenesis.

Methods: Atherosclerotic lesions $(n=76)$ oblained at autopsy $(N=6)$ or vascular surgery $(\mathrm{N}=8)$ were classified (type I-VI; American Heart Association (AHA) classification), immunolabeled with MIB 1 or the TUNEL technique and double stained with cell-type specific antibodies. Subsequently, labeling fractions were quantified.

Results: In type II-VI lesions, intimal DNA-synthesis was increased compared to that of the non-diseased (ND) arterial wall. DVA-synthesis peaked in eariy type 11 lesions (2.7 $\pm 0.5 \%$ vs $0.02+0.02 \%$ in ND; $p<0.05$ ), and declined to $0.7 \pm 0.2 \%$ in type $V$ lesions $(p<0.05)$. Interestingly, a second peak of DNA-synthesis of $1.7 \pm 0.1 \%$ was observed in type VI (ruptured plaque) lesions. Double staining revealed that DNA-synthesis was mostly confined to the macrophage derived foam cell (51.9\%). In type II lesions, $100.0 \%$ of all DNA-synthesizing cells were present in the intimal foam cell rich area, while in advanced type III, IV and V lesions, DNA-synthesis had shifted to the shoulder region $(74.8,78.5$ and $68.1 \%$ respectively). In type VI lesions, DNA-synthesis was present in the area underlying the plaque rupture $(52.7 \%)$. Apoptosis was only elevated in advanced type $\mathrm{V}, V$ and $V /$ lesions $(0.8 \pm 0.1,0.8 \pm 0.1$ and $1.1 \pm 0.1 \%$, respectively, $v s$ $0.0 \pm 0.0 \%$ in ND) and was predominant in the lipid core $(90.5 \%$ in type IV lesions; $54.2 \%$ in type $V$ lesions) or equally divided between the lipid core and the region underlying the plaque rupture ( 31.8 and $34.6 \%$ in type VI lesions). In type III-V/ lesions, $50.0,38.9,42.6$ and $42.8 \%$ of the TUNEL positive cells were macrophages.

Conclusions: In stable atherosclerotic lesions, DNA-synthesis is an early event, while apoptosis is a late event. Ruptured plaques showed a second peak of cell turnover. Lastly, cell turnover is mostly confined to the macrophage derived foam cell. 


\section{Introduction}

From previous studies, it is known that both DNA-synthesis and apoptosis are present in human atherosclerotic lesions ${ }^{1-7}$, and may play an important role in lesion development and in the conversion from stable to unstable plaques. $5.6,8,9$

The data published so far, show that DNA-synthesis in primary human atherosclerotic lesions is low $(0-3.5 \%) .^{1.5,7.10,11}$ This low level of DNA-synthesis might be expected in lesions that take many years to become clinically manifest. Topographical analysis in ruptured plaques reveals that DNA-synthesis is tightly correlated with areas of structural repair and foam cell infiltration. Cell phenotypes exhibiting DNA-synthesis in atherosclerotic lesions are either the macrophage-derived foam cell ${ }^{1,5,11}$ or the vascular smooth muscle cell. ${ }^{10}$

Enhanced rates of apoptotic cell death are also found in human atherosclerotic lesions. ${ }^{3,4,6,12,13}$ Apoptotic labeling indices of $0-40 \%$ have been reported and apoptotic nuclei are either mostly confined to macrophage-derived foam cells in the lipid core and in regions adjacent to the lipid core $3.4,12$ or to vascular smooth muscle cells in the fibrous cap. ${ }^{8.9 .14}$ Enhanced rates of apoptosis in the lipid core and/or fibrous cap are postulated to be major risk factors for the transition from stable to unstable plaques. $8,9,14$

There are severall limitations of the majority of these human studies. First of all, they almost invariably focus on advanced lesion types and therefore may have missed an early peak in cell turnover. Second, most studies have used atherectomy specimens. In these small samples, the morphology of the atherosclerotic lesion has been disrupted and, therefore, the topographical localization of both DNA-synthesis and apoptosis is hard to determine. ${ }^{15}$

Since DNA-synthesis and apoptosis are thought to be important features in atherogenesis, and since human data on cell turnover in all of the different stages of atherosclerotic lesion development, including ruptured plaques, are not available, we investigated the amount, phenotype and topographical localization of both DNA. synthesis and apoptosis in type I-VI lesions.

\section{Methods}

\section{Patient characteristics and tissue preparation}

In total, 76 atherosclerotic segments of non-branching parts of the descending aorta were obtained during autopsy (Dept. of Pathology. Academic hospital Maastricht) $(N=6)$ or vascular surgery (dept. of General Surgery, Academic hospitalMaastricht) $(\mathrm{N}=8$ ). Seven non-atherosclerotic segments of non-branching parts of the descending aorta of four of the six autopsy patients served as controll tissue. All tissue samples were obtained at comparable hemodynamic locations. Autopsy specimens were obtained from 3 adult male patients ( $58.3+1.8$ years old, range 55-61 years) and three adult female patients $(74,3 \pm 11.2$ years old, range $52-86$ years). The causes of death of the autopsy patients was diverse (cardiovascular disease, cancer). Surgical specimens were obtained from six male patients $(62.6 \pm 1.8$ years old, range 56-68 
years) and 2 female patienis (66.5 \pm 0.5 years old, range 66-67 years). Patients undergoing vascular surgery all had symploms of vascular occlusion. The investigation conlorms with the principles oullined in the "Declaration of Helsinky.

Immediately after harvesting, the samples were fixed in $10 \%$ phosphate buffered

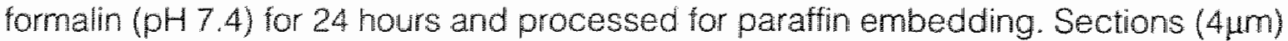
were cut and stained with haematoxylin and eosin. Only sections with an intact lesion morphology were selected. These selected lesions were classified I-VI according to the recommendations of the Committee on Vascular Lesions of the Council on Arteriosclerosis of the American Heart Association. ${ }^{16}$

\section{Immunohistochemistry}

\section{DWA-synthesis}

DNA-Synthesis was detected by use of the antibody MIB $\|$ (Immunotech, France), targeting the Ki-67 antigen, which is expressed in all stages of the cell cycle except $G$ and the early phase of $G_{1}$. The $\mathrm{Ki}-67$ antigen is mostly upregulated in the $\mathrm{G}_{2}$ and $M$ phases. Therefore, Ki-67 expression only correlates with DNA-synthesis and does not reflect DNA-repair. ${ }^{17.18}$

After dehydration and blocking of endogenous peroxidase activity with $0.3 \% \mathrm{H}_{2} \mathrm{O}_{2}$, the sections were placed in a $0.01 \mathrm{~mol} / \mathrm{L}$ citrate buffer, $\mathrm{pH} 6.0$ and boiled for $2 \times 3 \mathrm{~min}$. in a microwave. After subsequent washings in $\mathrm{H}_{2} \mathrm{O}$ and Tris Buffered Saline (TBS), the slides were incubated with the MIB 1 monoclonal mouse antibody for 60 min. at room temperature at a dilution of 1:50, followed by incubation with a biotinylated sheep ant: mouse IgG (1:250, Amersham, Life Science, England) for 30 min. at room temperature. Sections were then labeled for $30 \mathrm{~min}$. with an avidin-biotin peroxidase complex (Brunschwig. USA) 3,3'-Diaminobenzidine (DAB) was used as the chromogen. The sections were counterstained with haematoxylin and mounted with coverslips.

\section{Phenotyping of DNA-synthesizing cells}

To assess the phenotype of DNA-synthesizing cells, parallel sections were double labeled with MIB 1 and cell-type specific antibodies for macrophages (CD68), vascular smooth muscle cells (VSMC) (C-smooth muscle actin), endothelial cells (CD34) and Tlymphocytes (CD3). After performing the MIB 1 staining as described above, sections were washed with $\mathrm{H}_{2} \mathrm{O}$ and TBS and incubated with one of the antibodies (CD68: mouse monoclonal, 1:500, Dako, Denmark; $\alpha$-smooth muscle actin (ASMA): 1:500. mouse monoclonal, Dako, Denmark and CD3: 1:200, rabbit polyclonal, Dako, Denmark) for 45 min. at room temperature. Subsequently, sections were labeled for 30 min. with a biotin-labeled sheep anti-mouse IgG (1:250. Amersham, life Science. England) (CD68 and ASMA) or sheep anti-rabbit IgG (1:1000, Dako, Denmark) (CD3), followed by $30 \mathrm{~min}$. incubation with an avidin-biotin alkaline phosphatase (1:200, Dako, Denmark) complex. Fast blue (Sigma, MO, USA) was used as the chromogen. CD34 immunostaining (1:400 Becton Dickinson, CA, USA) preceded the MIB 1 staining. No counterstaining was performed and sections were mounted with immunomount (Shandon, PA, USA). 


\section{Apoptosis}

For the detection of apoptosis, the TUNEL-technique was used.,19 After dehydration, proteinase $K$ was applied (Boehringer Mannheim, Germany) (20 $\mu \mathrm{g} / \mathrm{ml}$ ) for $15 \mathrm{~min}$. at room temperature. After washing, sections were placed for $2 \mathrm{~min}$. in triton $X-100(0.1 \%) /$ sodium citrate $(0.1 \%)$ on $1 c e$, rinsed in Phosphate Buffered Saline (PBS, pH 7.2), incubated for $15 \mathrm{~min}$. in PBS containing $0.3 \% \mathrm{H}_{2} \mathrm{O}_{2}$, and incubated for 1 hour in $3 \%$ citric acid $(\mathrm{pH} 7.2)$ at room temperature. After 10 min. equilibration. sections were incubated with enzyme mix $(0.03 \mathrm{U} / \mu \mathrm{ll}$ TdT, $0.04 \mathrm{nmol} / \mu \mathrm{l}$ dig-dUTP, 1.5 $\mathrm{mM} \mathrm{CoCl})_{2}$ (Boehringer Mannheim, Germany) for 60 min. at $370 \mathrm{C}$. After blocking the reaction in stop/wash buffer and rinsing in $P B S$, sections were incubated with peroxidase labeled anti-digoxigenin (1:450, Boehringer Mannheim, Germany) for 30 min. DAB was used as the chromogen. The sections were counterstained with haematoxylin and mounted with coverslips.

\section{Phenotyping of apoptotic cells}

For the detection of the phenotype of apoptotic cells, double labeling with the TUNEL technique and antibodies against CD68, ASMA, CD34, and CD3 was performed at parallel sections. After the TUNEL technique, sections. were incubated with one of the above described antibodies for $45 \mathrm{~min}$. at room temperature. After washing in TBS, sections were labeled for $30 \mathrm{~min}$. with a biotin-labeled sheep anti mouse lgG (1:250, Amersham, Life Science, England)(CD68 and CD34) or sheep anti-rabbit IgG (1:1000, Dako, Denmark) (CD3), followed by $30 \mathrm{~min}$. incubation with an avidin-biotin alkaline phosphatase complex (1:200, Dako, Denmark). The alkaline phosphatase substrate kit (Brunschwig, the Netherlands) was used as the chromogen. ASMA immunolabeling preceded the TUNEL technique. No counterstaining was performed and sections were mounted with immunomount.

\section{Cell counting}

Tissue sections were investigated by light microscopy at * 400 magnification using a standard field size. All intimal nuclei $(600$-5000 nuclei) of the respective lesion type, and 10 fields of the underlying media $( \pm 400$ nuclei) were counted. Cells containing nuclear MIB 1 staining were considered to be DNA-Synthesizing cells. TUNEL positive nucle were only considered to be apoptotic nuclei when the cells also showed at least one of the morphological features of apoptotic cell death (cell shrinlage, aggregation of chromatin into dense masses and cell fragmentation). 20.22

The intimal labeling index, defined as the total number of intimal positive nuclei divided by the total nuclear intimal number, was calculated for the entire atherosclerotic lesion. The medial labeling index was calculated as the number of medial positive nuclel divided by the total number of positive nuclei present in 10 standard medial fields. The labeling index was calculated for both MIB 1-and TUNEL-stained sections. To obtain further insight into the distribution pattern of DNA-synthesizing and apoptotic cells, labeling indices were also determined at different sites within the lesion: the endothelial coverage (ec), foam cell-rich area (for), shoulder region (sh), the lipid core and regions adjacent to the lipid core (lc), the fibrous cap (fic) and the area underlying the plaque rupture (rupt). 
Double labeling of parallel sections was used to assess the phenotype of DNAsynthesizing and apoptotic cels. To calculate the different fractions of phenotypes, the number of MIB 1-positive or TUNEL-positive nuclei, also positive for one of the phenolype specific antibodies, was divided by the total number of MIB 1 - Or TUNELpositive cells. With the above described panel of antibodies (CD68, ASMA, CD34. CD3), the immunophenotype of $72.1 \%$ of the DNA-synthesizing and $59.9 \%$ of the apoptotic cells could be determined. All countings were performed by one investigator. The intra-observer variation was less than $10 \%$.

\section{Statistics}

To test whether lesions of the same type of different patients could be pooled, a oneway ANOVA was performed. This was performed separately for MBB and TUNEL stained sections. Since no statistical significance was found $(p>0.05)$, lesions of one type, but of different patients, were assumed to be comparable.

A Mann-Whitney $U$ test was used for comparisons between the lesion types. For comparisons within the lesion types, the Wilcoxon signed ranks test was used. In all tests, the level of statistical significance was assumed to be at $p<0.05$. Data are expressed as meantSEM.

\section{Results}

In total, 76 lesions $(n=8-12$ per lesion type) and 7 non-atherosclerotic segments (controls) of the non-branching parts of the descending aorta were investigated.

\section{DNA-synthesis}

Media

Medial DNA-synthesis in all lesion types was low $(0.06+0.03 \%)$, and not elevated in any of the lesion types as compared to the non-diseased (ND) arteriall wall $(p>0.05$ ). However, a small peak of $0.19 \pm 0.10 \%$ (compared to $0.0210 .01 \%$ ND) was observed in type I lesions $(p=0.31)$. Medial DNA-synthesis was contined to the vascular smooth muscle cell $(93.2 \%)$

\section{Intima}

In all lesion types, except lype I lesions, intimal DNA-synthesis was significantly elevated (fig. 3.1.a), as compared to the non-diseased arterial wall. The highest MIB 1 labeling was lound in type II (fatty streak) lesions $(2.7 \pm 0.5 \%$ vs $0.02 \pm 0.02 \%$ in the nondiseased arterial wall; $p<0.05$ ) (fig. 3.1a). With progression of lesion severity, DNAsynthesis decreased to $0.7 \pm 0.2 \%$ in advanced type $V$ lesions $\{p<0.05\}$. Interestingly. a second peak of DNA synthesis of $1.7 \pm 0.1 \%$ was observed in ruptured plaques (type $\checkmark$ ll lesions).

Not only the level, but also the site of DNA-synthesis changed with progression of the lesion (fig. 3.1a). In the early type II lesions, $400.0 \%$ of all DNA-synthesizing cells were found in the foam cell rich intimal area. With the development of a shoulder region in type III and IV lesions. DNA-Synthesis shifted to that region $(7.4 .8 \%$ and $83.9 \%$ 


\section{DNAsynthesis in hurran atherasderctic lesions}

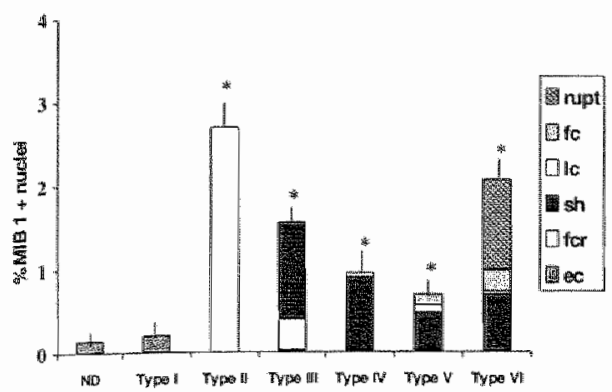

Phenctype of DNAsynthesizing colls

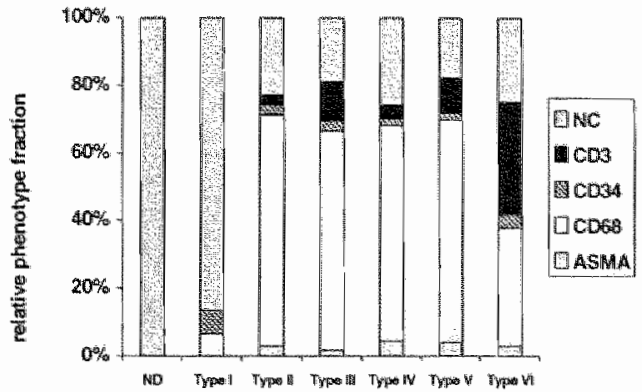

Fig. 3.1

A. Levell and localisation of DNA-synthesis in human atherosclerotic lesions. Abbreviations: ec, endothellial coverage; for, foam cell rich area: sh, shoulder region; Ic, lipid core; fo, fibrous cap; rupt, rupture: and ND, non-diseased arterial wall. " $p<0.05$

$B$. Phenotype of DNA-synthesizing cells in human atherosclerotic lesions. Abbreviations: ASMA, $\alpha-$ smooth muscle actin; CD68, macrophages; CD34, endotheliall ceils; CD3. Thymphocytes; and NC. not classified.

respectively; $p<0.05)$. In type $V$ lesions, the majority of DNA-synthesizing cells $(68.1 \%)$ was sitll present in the shoulder region, although the number had significantly decreased compared to that found in type III and IV lesions. This decrease is probably due to a shift of DNA-synthesis from the shoulder region to the fibrous cap in which $20.3 \%$ of all DNA-synthesizing cells was located. Type VI lesions showed a different pattern. The majority of DNA-synthesizing cells $(52.7 \%)$ in the ruptured plaques was found in the area underlying the rupture, while only $33.7 \%$ of all DNA-synthesizing cells was located in the shoulder region and $15.1 \%$ in the fibrous cap. Interestingly. DNA. synthesis was low in the lipid core of type $\mathrm{V}, \mathrm{V}$ and $\mathrm{V}$ l lesions $(5.4,11.6$ and $1.8 \%$ af all DNA-synthesizing cells respectively).

Double staining of all lesions revealed that $51.9 \pm 4.3 \%$ of the DNA-synthesizing cells were macrophage-derived foam cells, 3.040.9\% vascular smooth muscle cells. $3.2 \pm 1.0 \%$ endothelial cells and $12.7 \pm 2.6 \%$ were T-lymphocytes (fig. $3.1 \mathrm{~b}$ ). In all stable lesion types (type $\|-V$ ), the majority of DNA-synthesizing cells were macrophagederived farm cells (68.6\% (type II), 64.7\% (type III), 63.6\% (type IV) and 68.9\% (type V)). However, in ruptured plaques, the majority of DNA-synthesis was almost equally divided between macrophages and Twymphocyles $(35.23 .6 \%$ and $33.3 \pm 5.8 \%)$. 


\section{Apoptosis in human athercscierotic feston}

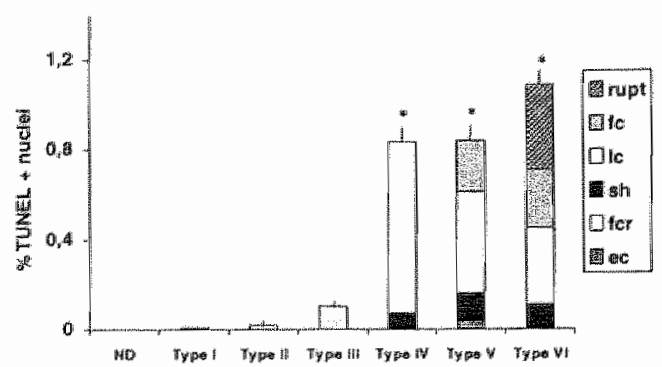

Phenotype of apoptotic cells

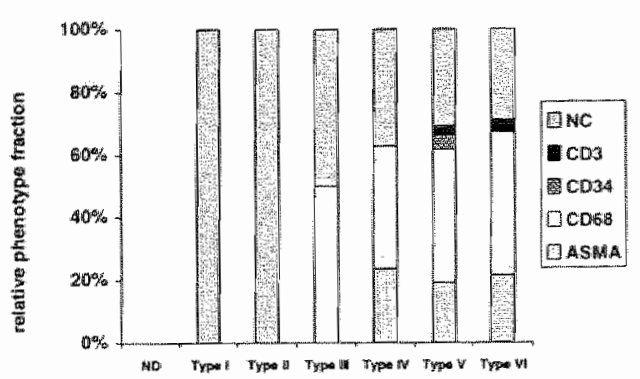

Fig. 3.2

A. Level and localisation of apoptosis in human atherosclerotic lesions. Abbreviations: $e_{\text {, }}$ endothelial coverage: for, loam cell rich area; sh, shoulder region; lc, lipid core; Ic, fibrous cap; rupt, rupture; and $N D$, non-diseased arterial wali. " $p<0.05$.

B. Phenotype of apoptotic cells in human atherosclerotic lesions. Abbreviations: ASMA, a-smooth muscle actir; CD68, macrophages, CD34, endothelial cells; CD3, T-lymphocytes; and NC, not classified.

\section{Apoptosis}

\section{Media}

Medial apoptosis was a rare phenomenon. In fact "the medial apoptotic labeling fraction was low in all lesion types $(0.01 \pm 0.01 \%)$ and did not increase during atherogenesis.

\section{Intima}

While intimal DNA-synthesis was an early event, apoptosis predominantly occurred in late stages of the disease (fig. 3.2a). In type I, II and III lesions, the fraction of apoplotic cells in the intima was not different from that in the non-diseased arterial wall. However: the apoptotic labeling fraction was significantly elevated in advanced type $I V$, $V$ and $V$ lesions $(0.8 \pm 0.1 \%$ in type IV, $0.8 \pm 0.1 \%$ in type $V$ and $1.1 \pm 0.1 \%$ in type $V I$ vs $0.0 \pm 0.0 \%$ in ND). In lype IV lesions, apoptosis was mostly confined to the lipid core (90.5\% of all apoptotic celis) (fig. 3.2a). In type V lesions, the apoptotic labeling fraction in the lipid core significantly decreased to $54.2 \%$ ( $p<0.05$ compared to type IV lesions). while $27.7 \%$ of all apoptotic cells were found in the fibrous cap. In ruptured plaques (type VI lesions), apoptosis was equally divided between the lipid core (31.8\%), fibrous cap $(24.3 \%)$ and the area underlying the rupture $(34.6 \%)$.

Double staining failed to identify the phenolype $41.8 \%$ of the apoptotic nuclei. it showed however that $37.8+4.4 \%$ of all apoptotic nuclei were macrophages, $17.0 \pm 3.3 \%$ vascular smooth muscle cells, $1.640 .8 \%$ endothelial cells and $1.8 \pm 0.9 \%$ T-lymphocytes (fig. 3.2b). In advanced lesion types (type III-Vi), the majority of identified TUNELpositive cells were macrophages $(50.0,38.9,42.6$ and $42.8 \%$ of all apoptotic cells respectively). The vascular smooth muscle cell was another prominent TUNEL- positive 
celltype $(23.6,19.2$ and $20.1 \%$ of all apoptotic cells in lype $\mathrm{V}, \mathrm{V}$ and $\mathrm{V}$ lesions, respectively).

\section{Discussion}

This is the irst study describing DNA-synthesis and apoptosis during several stages of atherosclerosis in humans. The low, but significantly elevated levels of DNA. synthesis that we found in advanced stable human atheromata are in accordance with other published data. $1,5,7,10,11,23$ As described in the present study, the presence of a peak in falty streaks (type II) is a remarkable feature of the pattern of DNA-synthesis during atherogenesis in humans. This early peak is in accordance with the peak in DNA-synthesis that has been observed in human in vitro studies ${ }^{24}$ and in several hypercholesterolemic animal models. ${ }^{25-27}$ Recently, Orekhow et al . also described enhanced proliferation in lipid rich lesions, while much lower levels of DNA-synthesis, were observed in fibrous lesions. A possible explanation for the occurence of this early peak is the mitogenic effect of shortly oxidized $L^{2} L^{28}$, that is present in macrophage derived foam cells in these early lesions.

While DNA-synthesis is an early phenomenon in atherogenesis, apoptosis shows the opposite. As our results show, apoptosis is confined to advanced stages of atherosclerosis and is not elevated in early type I, II and III lesions. Apoptosis in the intima of advanced lesion types has already been reported previously, but its level shows remarkable variations $(0-40 \%),{ }^{3,4.12-14.29}$ The high levels of apoptosis might reflect non-specific staining of calcium containing vesicles ${ }^{30}$, the detection of both apoptosis and oncosis ${ }^{14}$, and staining of RNA-synthesizing nucle ${ }^{22}$ by the TUNEL technique. In the present study, we therefore applied very strict criteria for the TUNEL method and the detection of apoptotic nuclei (pretreatment with citric acid, optimization of the enzyme concentration and apoptotic morphology). 22,30 Independent from our study. Kockx et al. , using the very same criteria, found comparable levels of apoptosis in human lesions. They also reported that apoptosis was predominantiy confined to advanced stages of the disease.

Most TUNEL positive nuclei were located in macrophages and vascular mooth muscle cells, as demonstrated by double labeling with CD68 and $\alpha$-smooth muscle actin. However, a significant firaction of TUNEL-positive cells could not be identified by the panel of antibodies used. This could reflect a loss of specific markers during apoptosis. $^{3,4,6}$

In a recent study, we investigated DNA-synthesis and apoptosis in type II-V lesions in ApoE* 3 Leiden mice. Interestingly, in this atherosclerotic mouse model, we observed the same pattern of cell tumover during atherosclerotic lesion development as in humans. "In accordance with the data described here ApoE*3Leiden mice also show a peak in DNA-synthesis in early type ll lesions and a decrease with lesion progression. Furthermore, apoptosis in atherosclerotic lesions in ApoE*3Leiden mice is also confined to advanced lesion types. ${ }^{27}$ 
Our data show that both parameters of cell turnover are increased in ruptured plaques (type VI). The majority of both DNA-synthesis and apoptosis in these lesions is present at the site of the plaque rupture, and cell turnover was mostly confined to inflammatory celltypes (macrophages and T-lymphocytes). Thus cell turnover, and especially apoptosis, may play an important role in the transition from stable to unstable plaques. Morphological characteristics of atherosclerotic lesions prone to rupture are an extensive lipid core, loss of vascular smooth muscle cells of the fibrous cap, macrophage infiltration into the shoulder region of the fibrous cap and thinning of the fibrous cap. ${ }^{81}$ These phenomena can, at least partially, be explained by the different patterns of cell turnover we observed during atherogenesis.

In accordance with other publications, we found that the majority of apoptosis in human atheromata occurs in macrophage derived foam cells in the lipid core and in regions adjacent to the lipid core..$^{3,4,6,12,13,29}$ Strongly oxidized LDL, that is abundantly present in the lipid core of atherosclerotic lesions, may be one of the factors that induce apoptosis in this region. Indeed, several in vitro studies have reported that. strongly oxidized LDL is capable of inducing apoptosis in macrophages. Moreover, macrophages are able to oxidize LDL which may induce self inflicted apoptosis. ${ }^{28.32 .33}$ The loss of cellular mass due to apoptosis in the lipid core and adjacent regions may contribute to further expansion and softening of the lipid core and may make the lesion more prone to rupture..$^{8.9}$

The vascular smooth muscle cell is the other cell type that shows elevated levels of apoptosis in advanced atherosclerotic lesions. Elevated levels of apoptosis in vascular smooth muscle cells not only results in a decreased content of vascular smooth muscle cells in the fibrous cap, but also reduces the population of cells that are able to synthesize extracellular matrix proteins. Both these factors contribute to thinning of the fibrous cap and therefore, to a decreased stability of the atherosclerotic plaque. .4,34,35 $^{\text {The }}$

The present study suggests, that cell turnover mechanisms may provide targets for therapeutical interventions in atherosclerosis. First of all, inhibition of DNA-synthesis may slow the progression of atherosclerosis. According to our findings, inhibitors of DNA-synthesis may be most effective, when applied early in the disease process (early DNA-synthesis peak). Inhibition of DNA-synthesis of advanced atherosclerotic lesions may even be undesirable, since it has been postulated that proliferation of vascular smooth muscle cells is part of a repair process and contributes to the maintenance of lesion stability. ${ }^{36,37}$

A different approach could be to interlere with the apoptotic process. Stimulation of apoptosis in atherosclerotic lesions may decrease lesion size. However, extensive apoptosis may make the lesion more vulnerable to rupture. Thus, since there appears to be such a delicate balance between the cell turnover mechanisms in atherosclerotic lesions, the effect of interventions, affecting parameters of cell turnover, is rather unpredictable. 


\section{Reterences}

1. Rekhter MD, Gordon D: Active proliferation of different cell types, including lymphocytes, in human atherosclerolic plaques. Am I Pathol 1995; 147:668-677.

2. Poss R: The pathogenesis of atherosclerosis: a perspective for the 1990s. Nature 1993:362:801-09.

3. Han DKM. Haudenschild CCH. Hong MK, Tirkle BT, Lean MB. Liau G: Evidence for apoptosis in human atherogenesis and in a rat wascular injury model. Am J Pathol 1995; 147:267-277.

4. Isner JM, Keamey M, Bortman S. Passeri J: Apoptosis in human atherosclerosis and restenosis. Circulation $1995,91: 2703-2711$.

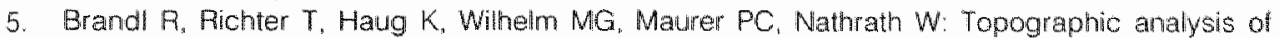
proliferative activity in carotid endarterectomy specimens by immunocytochemical detection of the cell cycle-related antigen Ki-67. Croulation 1997:96:3360-3368.

6. Kockx MM, de Meyer GRY, Muhring J. Jacob W. Bult H. Herman AG: Apoptosisand related proteins in different stages of human atherosclerotic plaques. Circulation 1998;97:2307-2315.

7. Orekhov AN, Andreeva EP. Mikhailova $\mid A$, Gordion D: Cell proliferation in normal and atherosclerotic human aorta: proliferative splash in lipid-rich lesions. Arteriosclerosis 1998:139:41. 48.

8. Lee RT, Libby P: The unstable atheroma. Arterioscler Thromb Vasc Biol 1997;17:1859-1866.

9. Davies Mu, Woolf N. Rowles P. Richardson PD: Lipid and cellular constituents of unstabie human aortic plaques. Basic Res Cardiol 1994:89 suppl 1:33-39.

10. O'Brien ER, Alpers CE, Stewart DK, Ferguson M, Tran N, Gordon D. Benditt EP, Hinohara T. Simpson JB, Schwartz SM: Proliferation in primary and restenotic coronary atherectomy tissue. Implications for antiproliferative therapy. Circ Res 1993:73;223-231.

11. Gordon D. Reidy MA, Benditt EP. Schwartz SM: Cell proliferation in human coronary arteries. Proc Natt Acad Sci USA 1990; 87:4600-4604.

12. Geng YJ, Libby P. Evidence for apoptosis in advanced human atheroma. Colocalization with interleukin 1 beta-corverting enzyme. Am \& Pathot 1995; 147: 251-266.

13. Bjorkerud $S$. Bjorkerud B. Apoptosis is abundant in human atherosclerotic lesions, especially in inflammatory cells (macrophages and T cells), and may contribute to the accumulation of gruel and plaque instability. Am I Pathol 1996; 149:367-380.

14. Crisby M, Kallin B. Thyberg U. Zhivotovsky B. Orrenius S, Kostulas V. Nilsson J: Cell death in human atherosiclerotic plaques involves both oncosis and apoptosis. Atherosclerosis 1997; 130:17-27.

15. Waller BF, Johnson DE. Schnitt SJ, Pinkerton CA, Simpson JB, Baim DS. Histologic analysis of directional coronary atherectomy samples. A review of findings and their clinical relevance. Am d Cardiol 1993;72:80E-87E.

16. Stary HC, Chandler AB, Dinsmore RE, Fuster $V$, Glagov S, Insull W, Jr, Rosenfeld ME, Schwartz Cu. Wagner WD. Wissler RW: A definition of advanced types of atheroscierotic lesions and a histological classification of atheroscierosis. A report from the Committee on Vascular Lesions of the Council on Arteriosclerosis, American Heart Association. Arterioscler Thromb Vasc Biol 1995: 15:1512-1531.

17. Gerdes J, L. L. Schlueter C. Duchrow M, Wohlenberg C. Gerlach C. Stahmer I. Kloth S, Brandl E. Flad $\mathrm{HD}$ : immunobiochemical and molecular biologic characterization of the cell proliterationassociated nuclear antigen that is defined by monoclonal antibody Ki.67. Am J Pathor 1991:138:867. 873.

18. McComick D. Chong H, Hobbs C. Datta C. Hali PA: Detection of the Ki-67 antigen in fixed and waxembedded sections with the monoclonal anibody M181. Hisiopathology 1993,22:355-360.

19. Wijsman $\mathrm{JH}$, Jonker RR, Keijzer $\mathrm{R}$, van de Velde $\mathrm{CJ}$, Cornelisse $\mathrm{CJ}$, van Dierendonk $\mathrm{JH}$ : A new method to detect apoptosis in paraffin sections: in situ end-labeling of fragmented DNA. $J$ Histochem Cytochem 1993:41:7-12.

20. Majno G. Joris I: Apoptosis, oncosis and necrosis. An overview of cell death. Am J Pahol $1995: 146: 3-15$

21. Schwartz SM, Bennett MR: Death by any other name. Am J Pathol 1995; 147: 229-234

22. Kackx MM, Muhring J. Knaapen MWM de Meyer GRY. RNA synthesis and splicing interferes with DNA in situ end labeling techniques used to detect apoptosis. Am J Pathol 1998; 152 885-888.

23. Gordon D. Schwartz SM: Cell proliferation in human atherosclerosis. Trends Cardiovasc Med $1991 ; 124-28$ 
24. Orekhow AN, Kosykh VA, Fepin VS, Smirnov VN: Cell proliferation in normal and atherosclerotic aorta. II. Autoradiographic observation on deoxyribonucleic acid synthesis in primary cell culture. Lab invest 1983,48: 749-754.

25. Rosenteld ME, Ross A: Macrophage and smooth muscle cel proliferation in atherosclerotic lesions of WHHW and comparably hypercholesterdemic lat-fed rabbits. Arteriosclerosis 1990:10:680 687.

26. Lutgens E, Daemen M, Kockx M, Doevendans P. Hokker M, Havekes $L$, Wellens $H$, de Muinck E: Atherosclerosis in $A P O E * 3$ Leiden transgenic mice: from prolferative to atheromatous stage. Circulation 1999,99:276m283.

27. Fischer-Dzoga K: Cellular proliferation, cellular death and atherosclerosis. Artery 1979:5:222-236.

28. Bjorkend B. Bjorkerud S: Contrary elfects of lightly and strongly oxidized LDL with potent promotion of growh versus apoptosis on arterial smooth muscle cells, macrophages and fibroblasts Arterioscler Thromb Vasc Biol 1996; 16:416-424

29. Hegyi L. Skepper JN, Cary NRB, Mitchinson MJ: Foam cell apoptosis and the development of the lipid core of human atherosclerosis. I Pathol 1996; 180:423-429.

30. Kockx MM. Muhring J. Bortier $H$, de Meyer GP, Jacob W. Biotin- or digoxigenin-conjugated nucleotides bind to matrix vesicles in atherosclerotic plaques. Am J Pathol 1996;148:1771-1777.

31. Falk E: Why do plaques rupture? Circulation 1992;86:ill30-11142.

32. Reid VC, Mitchinson MJ, Skepper JN: Cytotoxicity of oxidized low-densily lipoprotein to mouse periloneal macrophages: an ultrastructural study. J Pathol 1993;171:321-328.

33. Reid VC, Mitchinson MJ: Toxicity of oxidized low density lipoprotein towards mouse peritoneal macrophages in vitro. Atherosclerosis 1993:98:17-24.

34. Geng YJ. Henderson LE, Levesque EB. Muszynski M. Libby P: Fas is expressed in human atherosclerotic intima and promotes apoptosis of cytokine-primed human vascular smooth muscle cells. Arterioscler Thromb Vasc Biol 1997; 17 2200-2208.

35. Jowinge $S$, Crisby $M$. Thyberg J, Nilsson J: DNA-fragmentation and uitrastructural changes of degenerating cells in atherosclerotic lesions and smooth muscle cells exposed to oxidized LDL in vitro. Arterioscler Thromb Vasc Biol 1997:17:2225-2231.

36. Weissiberg PL. Clesham GJ, Bennett MR: Is vascular smooth muscle cell proliferation beneficial? Lancet 1996,347,305-307.

37. Flugelman MY, Virmani R, Correa R, Yu ZX, Farb A, Leon MB, Elami A, Fu YM, Casscells W. Epstein $S E$ : Smooth muscle cell abundance and fibroblast growth factors in coronary lesions of patients wihn nonfatal unsitable angina. A clue to the mechanism of transformation from the stable to the unstable clinical state. Circulation 1993;88:2493-2500. 


\section{Chapter 4}

Both compensatory enlargement and stenosis develop in ApoE $-/-$ and ApoE*3Leiden transgenic mice

Esther Lutgens, Ebo de Muinck, Sylvia Heeneman and Mat Daemen

Submitted

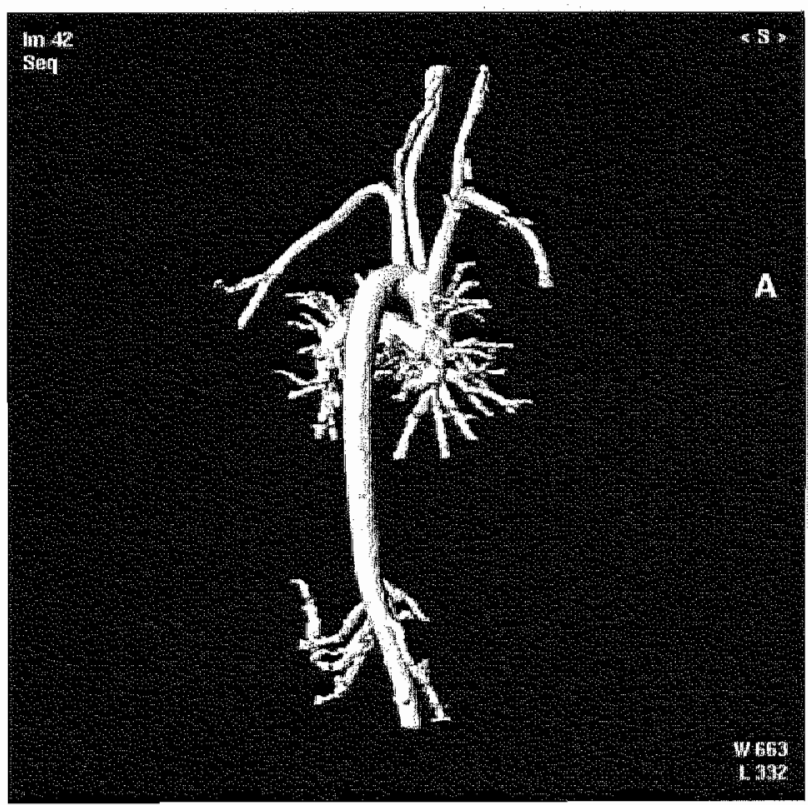




\section{Abstract}

Atherosclerotic mouse models develop little ischemic organ damage, and no infarctions, despite the presence of large atherosclerotic lesions. Therefore, one might speculate that luminal changes do not follow atherosclerotic lesion development. Since one phenomenon that may explain a discrepancy between luminal changes and lesion size is vascular remodeling, we measured parameters of vascular remodeling in the carotid arteries (CA), thoracic aorta (TA), and abdominal aorta (AA) of ApoE-l- and ApoE*3Leiden mice, two well known mouse models of atherosclerosis. Atherosclerotic lesions were classified (AHA $\|-V$ ), and plaque thickness, compensatory enlargement vs constrictive remodeling, lumen diameter, stenosis and media thickness were measured, relative to the nondiseased arterial wall.

In CAs, plaque thickness increased during atherogenesis. Concording to this increase, CAs showed compensatory enlargement (ApoE-1-: $+55 \%$, ApoE*3Leiden $438 \%$ ). Regression analysis revealed a positive correlation between plaque and lumen area (A.poE-1-; $R=0.95$, ApoE*3Leiden: $R=0.90$ ). Medial thinning and elastolysis were also observed. During atherogenesis, lumen diameter decreased (ApoE-1-: $-69 \%$, ApoE*3Leiden: $-40 \%$ ) and stenosis $>70 \%$ developed. TA and AA showed similar features, but neither developed a progressive decrease in lumen diameter nor stenosis $>70 \%$.

In CA. TA and AA of ApoE-1- and ApoE*3Leidlen mice, atherogenesis is associated with compensatory enlargement, medial thinning and elastolysis. A progressive decrease in lumen diameter and stenosis $>70 \%$ only occur in CA. Vascular remodeling is more prominent in ApoE-t-mice. 


\section{Introduction}

For a long time, the arterial system was considered to be a rigid tube that showed a decrease in lumen diameter in response to a growing plaque mass.' However, in 1987, Glagow, and many others thereafter, showed that coronary arteries developed compensatory enlargement in response to plaque growth ${ }^{2-6}$ Later it was shown, that besides compensatory enlargement, constrictive remodeling may develop? The mode of remodeling (compensatory vs constrictive) may vary strongly over the length of one artery, and between different arteries. ${ }^{8}$ Clinically, constrictive remodeling is associated with ischemic organ complications."

Although enlargement and constrictive remodeling have extensively been reported in different animal models after balloon angioplasty, like the baboon ${ }^{10,11}$. the rat, the rabbit ${ }^{12}$ and the pig $^{13}$, an animal model of de novo atherosclerosis that shows constrictive remodeling with significant stenosis and ischemic organ complications is still lacking. Hypercholesterolemic Macaque monkeys, rabbits and pigs all show arterial compensatory enlargement, while high gradestenosis or a decrease in lumen diameter are hardly observed. ${ }^{10,11}$

Also ApoE- - mice, the most frequently used atherosclerotic mouse model, show compensatory enlargement, and, when fed an extremely high cholesteral diet, or during infusion of angiotensin II, even aneurysm formation. ${ }^{14-17}$ Some ApoE-/ mice do develop significant stenosis in the external carotid artery, however without evidence of ischemia. ${ }^{15}$

Since parameters of vascular remodeling during lesion progression in atheroscleratic mouse models are largely unknown, we investigated these parameters in all stages of atherosclerosis, in 3 differently sized vessels, in 2 different hypercholesterolemic mouse models, the ApoE- - mouse ${ }^{18}$, and the ApoE*3Leiden transgenic mouse. ${ }^{19-21}$ Our data indicate that both mouse strains show compensatory enlargement, medial thinning and elastolysis in the carotid arteries, the thoracic and the abdominal aorta. Interestingly, the carotid arteries showed a decrease in lumen diameter and stenosis $>70 \%$, especially in type IV and $\checkmark$ lesions. However, constrictive remodeling and ischemic organ damage did nol develop.

\section{Materials and Methods}

\section{Mice}

Data of the present study were obtained from ApoE-1- mice $(n=14)$ and ApoE*3Leiden mice $(n=45)$, fed an atherogenic diet for $4-12$ months. For validation purposes (see results section), wild type (C57Bl6) mice on a normal chow $(n=6)$ or atherogenic diet $(n=6)$ were used.

\section{Tissue handling}


After the experimental period, mice were sacrificed and tissue was processed as described previously." In summary, the arterial tree was perfused under standardized pressure $(100 \mathrm{mmHg})$ with PBS $(3 \mathrm{~min})$ and $10 \%$ phosphate buffered
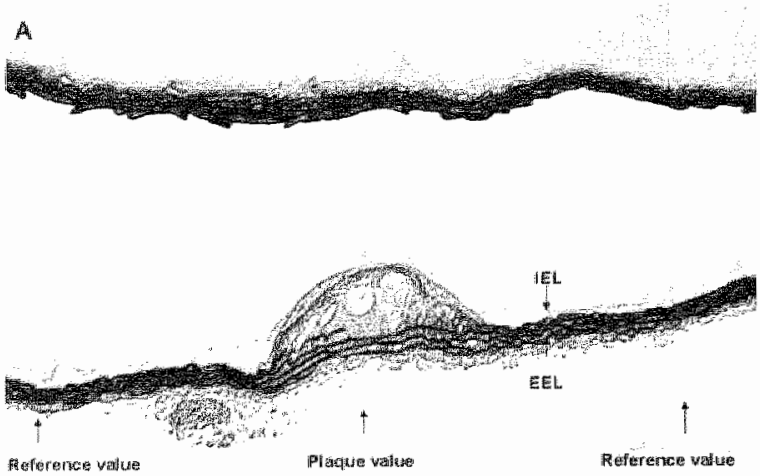

B

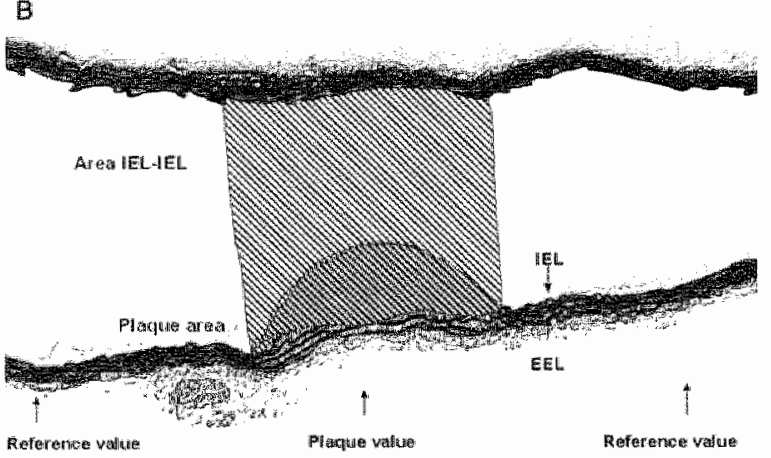

Fig. 4.1

A. Figures showhing a Lawsor stalited section of a TA containing a lype fll lesion. Measurement points for reterence walues and plaque values are indicated. IEL, internal elastic lamina; EEL, external elastic lamina.

$B$. Figure showing measurement area, lumen area and the area between both IEL, used for regression analysis.

formalin ( $3 \mathrm{~min}$ ) both containing $0.1 \mathrm{mg} / \mathrm{ml}$ natrumnitroprusside, through a catheter introduced into the left ventricular apex. Subsequently, the entire arterial tree was excised and formalin fixed for 24 hours. Both CAS, the TA and AA were embedded longitudinally in paraffin and $4 \mu \mathrm{m}$ sections were cut. Five sections of the CA. TA andAA (16um apart) were stained with haematoxilin and eosin and classified from II$V$ according to the AHA classification. ${ }^{22}$

\section{Monohometry}

For morphometry, 5 sections of CA. TA and AA, consecutive to the HE-stained sections, were stained Lawson (a modified elastica von Giesson staining). 
Morphometric parameters were determined using a microscope coupled to a computerized morphometry system (Quantimet 570, Leica, the Netherlands).

Parameters were measured at the center of the lesion as well as at the nondiseased part of the same vessel (10qum proximal and distal of the atherosclerotic plaque). These measurements were taken as reference values (fig. 4.1a).

Plaque thickness at the center of the lesion, plaque area, lumen area, and the area between both internal elastic laminae were measured as described in tigure $4.1 \mathrm{a}$ and $4.1 \mathrm{~b}$. Compensatory enlargement/constrictive remodeling was defined as the relative increase/decrease of the distance between both internal elastic laminae compared to reference values. Relative lumen diameter was defined as the distance between both internal elastic laminae minus plaque thickness, compared to reference values. Media thinning/thickening was defined as the relative decrease/increase of the media underlying the plaque (distance between internal elastic lamina and external elastic lamina) compared to reference values. The amount of medial elastolysis was defined as the number of elastin breaks in the media underlying the atheroscleratic lesion. The percentage stenosis was defined as plaque diameter divided by the distance between both internal elastic laminae. Post-stenotic dilatation was defined as the difference of the distance between both elastic laminae of the reference value sites distal and proximal from the atherosclerotic lesion.

\section{Lipia profile}

Plasma cholesterol and plasma triglyceride levels were determined in duplicate using a colorimetric assay (CHOD-PAP 1442341 and GPO-PAP 701912 respectively, La Roche).

\section{Statistics}

Values are given as meantSEM. Relative increases and decreases were obtained by dividing the value of the center of the lesion by the mean of both reference values. Arteries in which it was impossible to obtain proper reference values, as well as arteries containing 2 opposite lesions in one segment were discarded. Differences during lesion progression were tested by a one way ANOVA. For the analysis of differences between the same lesion types between both mouse models. a Mann-Whitney $U$ test was used. Regression analysis was performed to test the correlation between plaque area, lumen area, and the area between both IEL. To test whether vascular remodeling was an age dependent effect, reference values, as well as plaque values of mice of the different diet groups $(4,6,9,12$ months) were compared by a 2-way ANOVA. The level of statistical significance was assumed to be at $p<0.05$. 


\section{Results}

\section{General}

Mean body weight did not differ between the mouse strains. Survival rates were 92\% for ApoE-1-mice, 96\% for ApoE*3Leiden mice, and 100\% for C57Bl6 mice. Histological analysis of heart, brain, lungs, kidneys and liver (HE stained sections) revealed no ischemic damage. In one ApoE-l- mouse, an apical myocardial infarction caused by LAD occlusion was observed, and in one ApoE*3Leiden mouse, cerebrall infarction was observed. In ApoE*3Leiden mice, cholesterol and triglyceride levels were elevated compared to ApoE- $/$ mice (cholesterol: $34.0 \pm 0.6$ mmol// vs $24.0 \pm 1.2 \mathrm{mmo} / / /$; triglyceride levels: $2.0 \pm 0.2 \mathrm{mmol} / \mathrm{l}$ vs $0.9 \pm 0.1 \mathrm{mmol} / \mathrm{l}$. In C57Bl6 mice, these levels were low (normal chow: cholesterol $0.6 \pm 0.3 \mathrm{mmol} / \mathrm{l}$, triglycerides $0.1 \pm 0.0 \mathrm{mmo} / / /$; diel $0.9 \pm 0.4 \mathrm{mmol} / /$ and $0.1 \pm 0.0 \mathrm{mmol} / / \mathrm{l}$, respectively).

For validation of the measurements, reference values of ApoE-/ and ApoE*3Leiden mice were compared with remodeling parameters obtained from non-diseased arteries of C57BI6 mice on normal chow diet or on atherogenic diet. No significant differences were found between reference values of arteries of atherosclerotic and non-diseased mice. Also, remodeling parameters between C57Bl6 mice on normal chow and atherogenic diet were not different. To investigate whether remodeling was an age dependent effect, reference values, as well as plaque values of mice of the different diet groups $(4,6,9,12$ months diet) were compared. Age dependent remodeling was not observed.

In total, 367 atherosclerotic lesions (=1835 slides) of three different sized arteries were analyzed (ApoE-1-CA $n=37 ;$ TA $n=43 ;$ AA $n=99$; ApoE*3Leiden CA $n=98 ;$ TA $n=40 ;$ AA $n=50$ ).

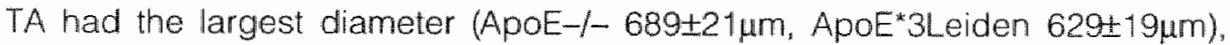
followed by the AA $(479 \pm 13 \mu \mathrm{m}$ and $5.41 \pm 17 \mu \mathrm{m})$ and the $C A(285 \pm 9 \mu \mathrm{m}$ and $289 \pm 7 \mu \mathrm{m})$.

\section{Vascular Remodeling}

\section{Carotid arteries}

Plaque thickness increased during the progression from type $\|$ to type $V$ lesions (ApoE-t-: $+804 \pm 89 \%$, ApoE*3Leiden: $+547 \pm 113 \%$ ) (fig. 4.2a). Compared to ApoE*3Leiden mice, the increase in plaque thickness was significantly higher in ApoE-1- mice, especially the thickness of type IV and V lesions (fig. 4.2a).

The increase in plaque thickness was associated with the development of compensatory enlargement. Compensatory enlargement (from type II-V lesions) was $+55 \%$ in ApoE-l- mice, and $+38 \%$ in ApoE*3Leiden mice (fig 4.3a). In ApoE-1mice, compensatory enlargement was more prominent than in ApoE*3Leiden mice. Statistically significant differences between both mouse strains were observed in lype IV and $V$ lesions. (fig. 4.3a). Regression analysis revealed a high correlation between plaque area and compensatory enlargement (ApoE- mice $\mathrm{R}=0.95$; ApoE*3Leiden mice $R=0.90$ ) (fig 4.4ab).

Despite the development of compensatory enlargement, lumen diameter decreased and stenosis $>70 \%$ developed. In ApoE-I- mice, the decrease of lumen diameter was more prominent compared to ApoE*3Leiden mice (ApoE-I-type $\|$ : 


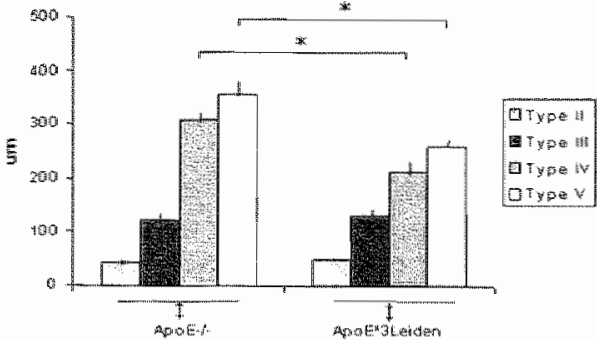

目

Planque thickmess (IA)

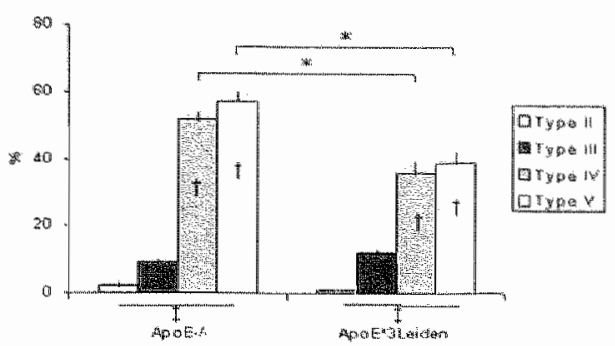

B Compensatory enlargement (IA)

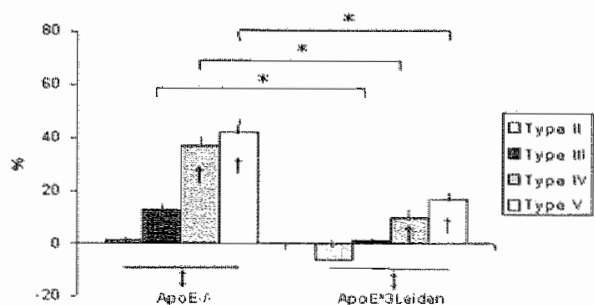

C Compens at ory enlargentent [APX)

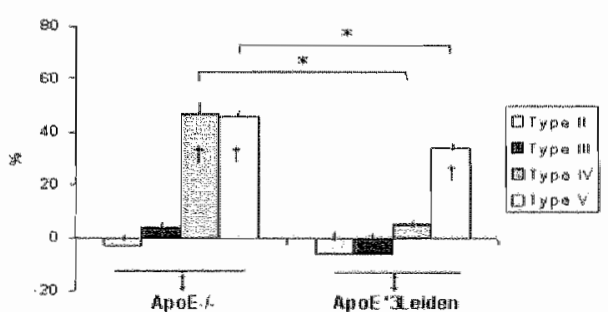

Fig. 4.2 (left)

Plaque thickness in all atherosclerotic lesion types in $A$, the carolid arteries. $B$. thoracic aorta and $C$, abdominal aonta of ApoE- $/$ and ApoE"3Leiden mice. Data are compared to the respective lesion type beiween both mouse models (" p<0.05). To evaluate plaque thickness during atherogenesis within a mouse strain. a one-way ANOVA was perlormed ( 1 p $<0.05$ ) Data reveal an increase in plaque thickness during atherogenesis in all three vessels.

Figl. 4.3 (right)

Compensatory enlargement in all atherosclerotic lesion types in $A$, the carotid arteries, $B$. thoracic aorta and $C$, abdominal aorta of ApoE- $/$ and ApoE 3Leiden mice. Data are compared to the respective lesion type between both mouse models ( $p<0.05$ ), or to relerence values (t) $p<0,05$ ). To evaluate compensatory endargement during atherogenesis within a mouse strain, a one-way ANOVA was performed $(*$ p<0.05). Dala reveal the presence of compensatory enlargement in all three vessels during atherogenesis, most prominently in ApoE-t- mice. 


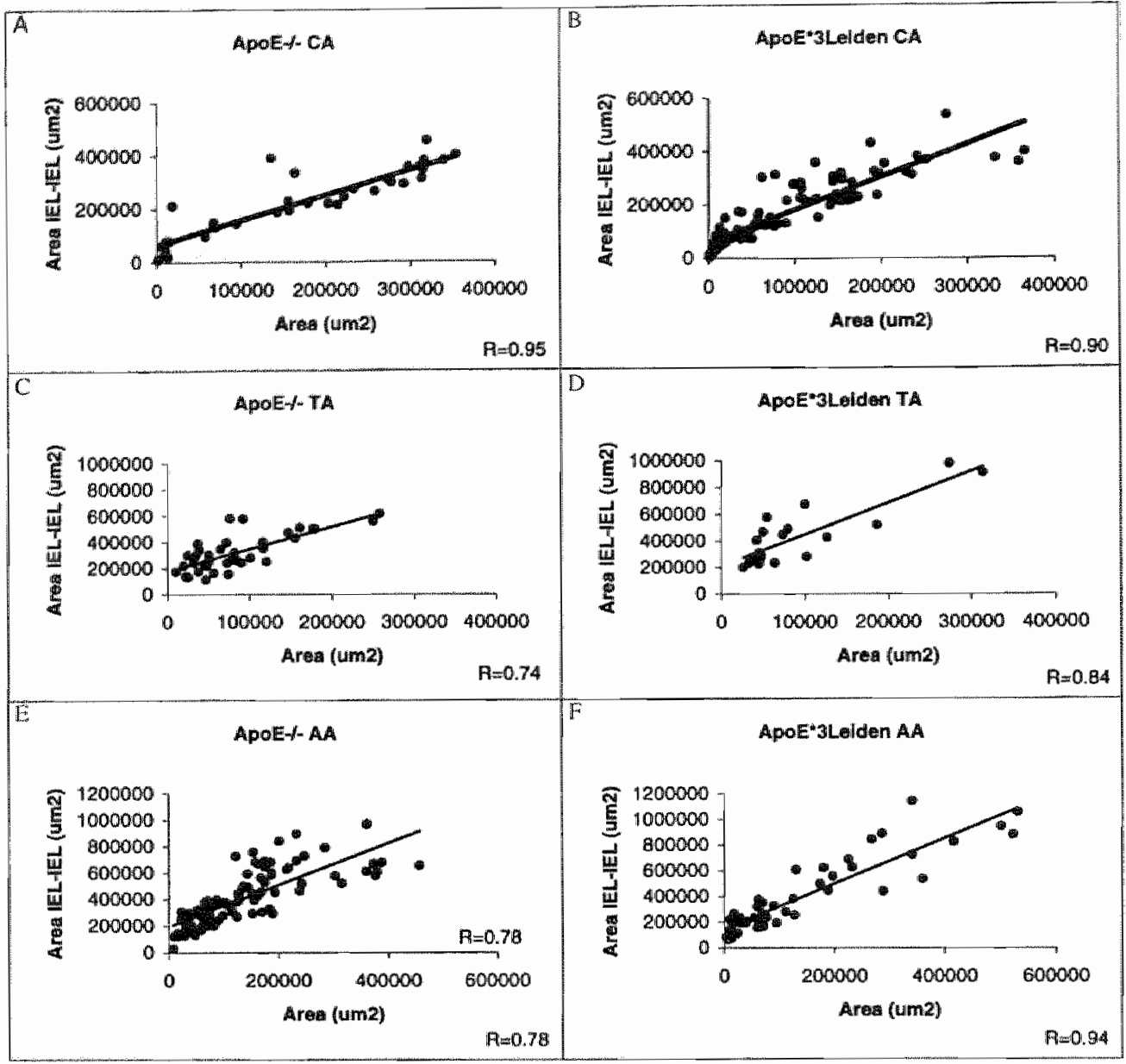

Fig. 4.4

Regressicn analysis, revealing a positive correlation between plaque area and the area between both internal elastic laminae (IEL), in $A B$. the carotic arteries, $C D$, thoracic and $E F$, abdominal aorta of ApoE-"-and ApoE*3Leiden mice, indicating compensatory enlargement.

$-19 \pm 3 \%$, type $V$ lesions: $-88 \pm 9 \%$; ApoE 3 Leiden type II: $-23 \pm 2 \%$, type $V-63 \pm 5 \%$ ) (fig 4.5a). Stenosis $>70 \%$ were observed in advanced type IV and $V$ lesions, and

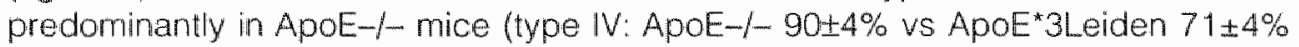
and type $V: 91 \pm 5 \%$ vs $73 \pm 4 \%$ ) (fig. 4.6a). Despite the development of stenosis, significant post-stenotic dilatation was not observed. Regression analysis revealed no correlation between plaque area and lumen area (ApoE- $-R=0.21$; Apo $E^{*} 3 \mathrm{Leiden} \mathrm{R}=0.56$ ). Constrictive remodeling (defined as negative compensatory enlargement) did not occur (fig. 4.3a). 


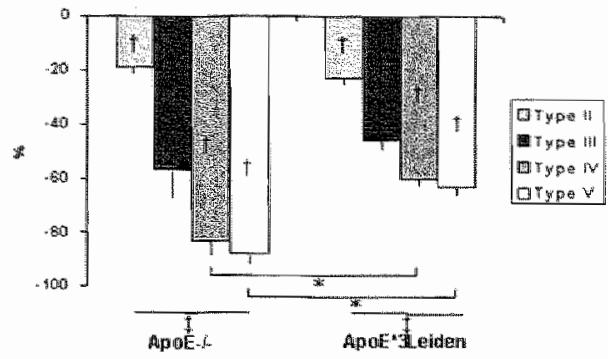

战

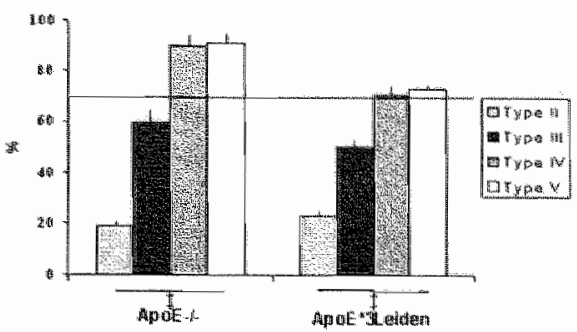

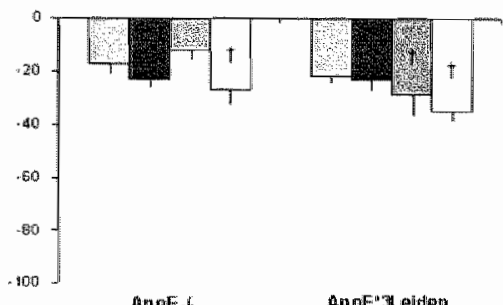

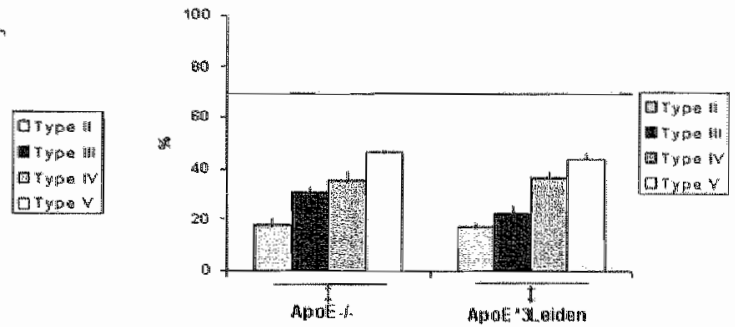

c. Relathe lumen dilameter (AA)

$c$

Sienos

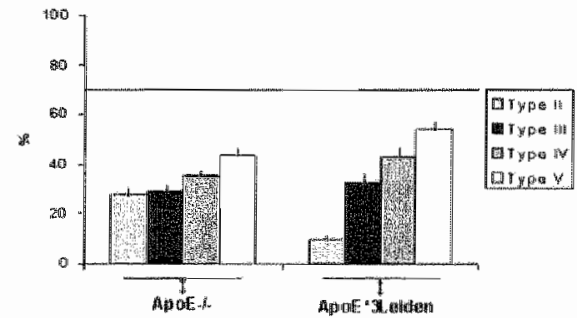

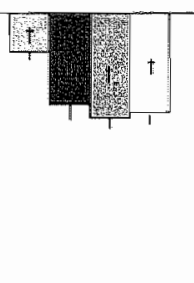

ApoE" Yelden

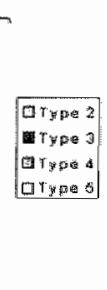

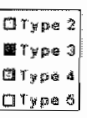

ApoE, 4tonosis (TAM)

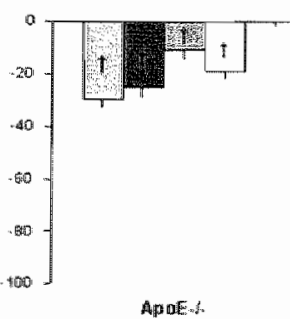

Fig. 4.5 (left)

Relative lumen diameter in all atherosclerotic lesion lypes in the carotid arteries (a), thoracic aorta (b) and abdominal aorta (c) of ApoE-\% and ApoE*3Leiden mice. Dala are compared to the respective lesion type between both mouse models (" p<0.05), or to reference values $(1 p<0.05)$. To ewaluale relative umen diameter during atherogenesis within a monse strain, a oneway ANOWA was pertormed ( $\$$ p 0.05 ). The decrease in umen dilameler during atherogenesis was most prominent in the carotid arteries of ApoE-1-mice.

Fig. 4.6 (right)

Percentage stenosis in all atherosclerotic llesion types in the carotid arteries (a). thoracic aorta (b) and abdominal aorta (c) of ApoE-/-and ApoE*3Leiden mice. Data are compared to the respective tesion lype between both mouse models ("p<0.05). To evaluate the progression of stencsis during atherogenesis within a mouse strain, a oneway AMOVA was perforned (f. p<0 05). Significant stenosis was defined as stenosis $>70 \%$. Data reweal that sigmificant stenosis onily develops in type Wand V lesions of the carotid arteries, and most prominent in ApoE- 


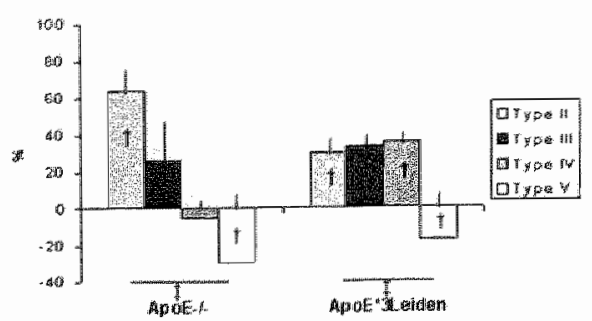

a

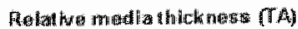

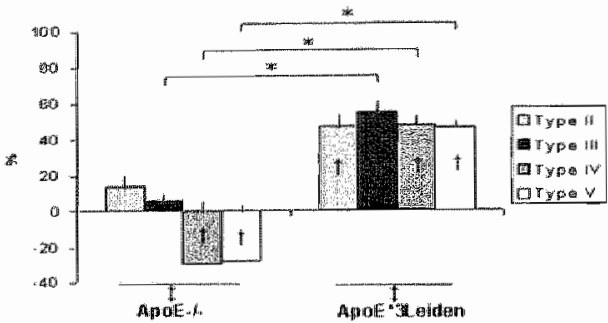

c

Realat ive muedia (hickness (AA)

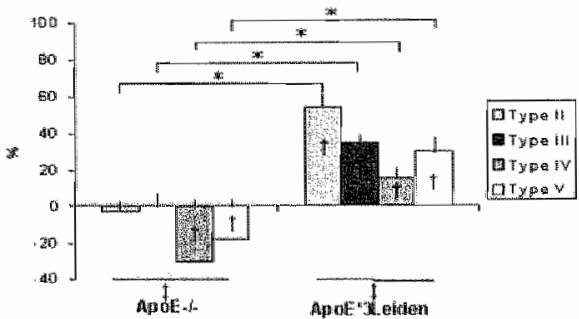

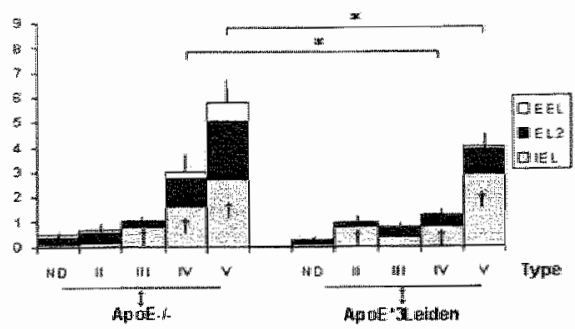

E Elasin Breaks (TA)

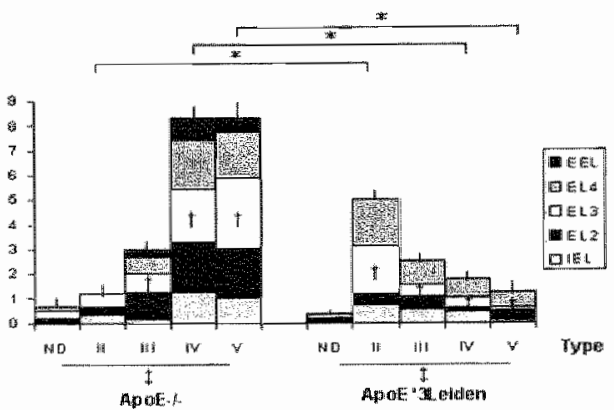

$c$

Elas tin breaks (An)

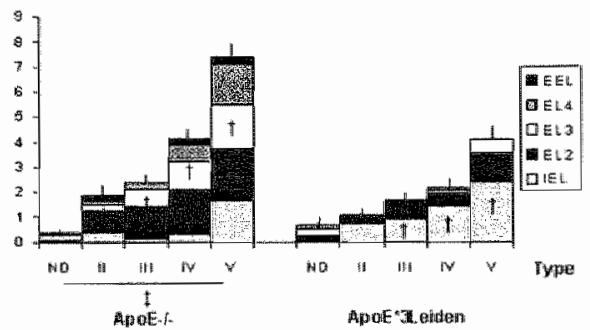

Fig. 4.7

Relative media thickness in all atherosclerotic lesion types in $A_{3}$ the carotid arteries, $B$, thoracic aorta

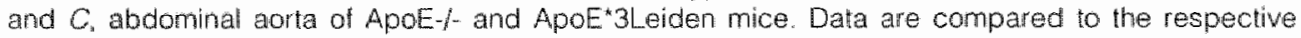
lesion type between both mouse models (* $p<0.05$ ) or to reference values $(\dagger p<0.05$ ). To evaluate the progression of stenosis during atherogenesis within a mouse strain, a one-way ANOVA was performed $(\neq p<0.05)$.

Fig. 4.8

Medial elastolysis and its distribution among the different elastic laminae (IEL $=$ internal elastic lamina, EL2 = the second elastic lamina from the luminal site. $E L 3=$ the third elastic lamina from the luminal site, $E L 4=$ the fourth elastic lamina from the luminal site, $E E L=$ external elastic lamina) in all atherosclerotic lesion types and the non-diseased arterial wall (ND) in $A_{\text {. }}$ the carotid arteries, $B$, thoracic aorta and $C$, abdominal aorta of ApoE-/-and ApoE*3Leiden mice. Data are compared to the respective lesion type between both mouse modeis (" $p<0.05$ ) or to the non-diseased arterial wall ( $t$ $p<0.05$ ). To evaluate the progression of stenosis during atherogenesis within a mouse strain, $a$ oneway ANOVA was performed $(\$ p<0.05)$. 
Also, the media underlying the plaque changed. First of all, in both mouse models, the media hypertrophied in early lesions (type II: ApoE-1- $+64 \pm 17 \%$, ApoE*3Leiden $+31 \pm 11 \%$ ), and atrophied in type $V$ lesions (type $V$ : ApoE-1$-29 \pm 7 \%$, ApoE 3 Leiden $-17 \pm 6 \%$ )(fig. 4.7 a). Second, medial elastin breaks were observed. Interestingly "the number of medial elastin breaks, as well as the distribution pattern differed between both mouse models. In ApoE-1- mice, the mean number of elastin breaks was $4.1 \pm 0.6$, while it was only $1.9 \pm 0.2$ in ApoE*3Leiden mice, compared to $1.1 \pm 0.3$ and $0.6 \pm 0.4$ in the non-diseased parts (fig 4.8a). Furthermore, in ApoE-I- mice, breaks were distributed equally throughout the lesion, while in ApoE*3Leiden mice, breaks were confined to the IEL $\$ 37.8 \%$ in IEL in ApoE-/-vs $70.7 \%$ in ApoE*3Leiden mice) (fig. 4.8a).

\section{Thoracic and Abdominal aorta}

Although an increase in plaque thickness, compensatory enlargement, as well as a positive correlation between plaque area and compensatory enlargement (TA: ApoE- $-\mathrm{t}-\mathrm{R}=0.74$ ApoE*3Leiden $R=0.84, A A \quad R=0.78$ and $R=0.94$ ) were also observed in TA and AA (figs. 4.2bc, $4.3 \mathrm{bc}$ and $4.4 \mathrm{c}-\mathrm{f}$ ), a progressive decrease in lumen diameter, as well as stenosis $>70 \%$ did not occur (figs. $4.5 \mathrm{bc}$ and $4.6 \mathrm{bc}$ ). No significant differences between ApoE- $-1-$ and ApoE*3Leiden mice were found. In TA and $A A$, regression analysis revealed no negative correlation between plaque area and lumen diameter (TA ApoE-l- $R=0.32, A p o E^{*} 3$ Leiden $R=0.57$ and $A A R=0.42$ and $R=0.56$ ). Also in TA and $A A$, medial changes were observed in both mouse models. In ApoE-/- mice, progressive medial thinning occurred (TA-28 $\pm 9 \%$ in type $\mathrm{V}, \mathrm{AA}-18 \pm 3 \%$ in type $\mathrm{V}$ ), while in ApoE ${ }^{\star} 3$ Leiden mice, the media hypertrophied in all lesion types (TA $+46 \pm 10 \%, A A+30 \% \pm 12$, both in type $V$ ) (fig. $4.7 \mathrm{bc}$ ). The pattern of elastolysis equaled that in the CA (fig. $4.8 \mathrm{bc}$ ).

\section{Discussion}

This manuscript is the first to provide data on parameters of vascular remodeling in three different sized arteries of two hypercholesterolemic mouse models, in all atherosclerotic lesion types. The main findings are that 1) both mouse models develop compensatory enlargement, correlated with plaque area, 2) only carotid arteries are able to develop a progressive decrease in lumen diameter andstenosis $>70 \%$, 3) medial hypertrophy is a feature of early atherosclerosis, while medial thinning with elastin breaks are observed in advanced lesions, and 4) the development of constrictive remodeling is lacking.

Vascular remodeling is an adaptive process that occurs as a response to chronic changes in hemodynamic conditions. ${ }^{3.23}$ When a human atherosclerotic plaque develops, compensatory enlargement, as well as poststenotic dilatation occurs as an attempt to maintain pre-existing flow and shear stress. ${ }^{4-6,23,24}$ In early stages of atherosclerosis, even overcompensation of the lumen was observed.,23,25 When atherosclerotic lesions progress, the capacity of the arterial wall to compensate for the increase in plaque thickness decreases. At this stage, compensatory enlargement is inadequate ${ }^{4,26.27}$, and a correlation between plaque 
area and lumen loss can be found ${ }^{23}$ Additionally, constrictive remadeling, with a decrease in lumen diameter has been reported.29

Consistent with data found in humans and atherosclerotic animal models ${ }^{12.14-}$ 16.29. we demonstrate compensatory enlargement in advanced atherosclerotic lesions of both ApoE-/ and ApoE*3Leiden mice. However, overcompensation of the lumen in early lesions and the development of poststenotic dilation was not observed in either of the 2 mouse models. As in other animal models of de novo atherosclerosis, ApoE-1- and ApoE*3Leiden mice failed to develop (inadequate), constrictive remodeling. However, in contrast to other atherosclerotic animal models, both mouse models did develop significant stenosis in the common carotid arteries, but not in the thoracic or abdominal aorta. These data are consistent with the data of Seo et al., who observed significant stenosis in peripheral vessels (popliteal and external carotid anteries) of 9 out of $12 \mathrm{ApoE}-1-$ mice. ${ }^{15}$ The difference in remodeling we observed between the different sized arteries can be due to the smaller vessel diameter of the carotid artery. In the carotid artery, vessel diameter is twice as small, while maximal plaque thickness is equal to that in the thoracic or abdominal aorta. This suggests that the vessel stenoses twice as fast in carotid arteries compared to the thoracic or abdominal aorta. A reason for this phenomenon might be the different structurai composition and function of the carotid artery, which is a musculo-elastic vessel with a relative thin media, and the thoracic or abdominal aorta, which is rather a thick walled conduit vessel.

Until now, the mechanisms of vascular remodeling are poorly understood Postulated mechanisms are changes in shear stress, shear stressed induced $\mathrm{NO}$ production, endothelial dysfunction, hypertension, and the activation of matrix degrading proteins.

During atherogenesis, shear stress changes, and as a response, the arterial endothelium adapts by inducing the chronic expression ofvasodilatory substances like nitric oxide (NO) ${ }^{30,31}$ Consequently, the artery dilates and thereby compensates for the initial lumen loss. On the other hand, atherosclerosis induces endothelial dysfunction, causing an impaired endothelial dependent relaxation, which contributes to inadequate vasodilation, and inadequate compensatory enlargement. ${ }^{32.34}$ In addition, it is reported that a decreased blood flow causes constrictive remodeling. ${ }^{24,30}$ These features also apply, albeit to a lesser extent in ApoE-/-mice. Although ApoE-/-mice develop compensatory enlargement, ApoE-/ mice show a diminished wasodilatation response to acetylcholine, and to NO. ${ }^{16,35-37}$ The severity of endothelial dysfunction in ApoE-1- mice varies in the different studies, and seems to be positively correlated with age, and atherogenicity of the diet. ${ }^{16.35 .38}$ Furthermore, the mouse hyperdynamic circulation may result in a contimuous release of vasodilatory factors, that might prevent the development of constrictive remodeling. ${ }^{39}$

In humans, hypertension is also correlated with an increase in arterial diameter. and could thereby contribute to compensatory enlargement ${ }^{40}$ However, vice versa, the stiffness of a chromic dilated artery could facilitate the manifestation and maintenance of systolic hypertension. ${ }^{40}$ Interestingly, hypertension and increased 
arterial wall stiffness were also observed in ApoE- - mice, possibly contributing to dilation of the arteries. ${ }^{35.38}$

Another mechanism, responsible for remodeling is the involution of the support structure of the arterial wall. ${ }^{9.41 .42}$ During atherogenesis, collagen, as well as elastin is degraded. This often results in an atrophic, elastolytic media and a decreased collagen content of the adventitia. As a response, the artery enlarges, often resulting in aneurysm formation. ${ }^{41.43}$ ApoE- $/$ - mice fed a severe atherogenic diet, or after 1 month of angiotensin $1 /$ infusion, develop medial elastolysis with aneurysm formation. ${ }^{14.17}$ Degradation of collagen and elastin is mediated by plasmin dependent activation of matrix metalloproteinases (MMPS), especially MMP-3, - 9, 12 and -13 , which are produced by infiltrating macrophages. ${ }^{14}$ Other observations support the important role of MMPs in aneurysm formation are that administration of an MMP inhibitor in rats and targeted disruption of MMP-9 in mice suppress the development of experimental abdominal aortic aneuryms. ${ }^{445}$ Also in the present study, medial elastolysis was observed in ApoE-1- and ApoE*3Leiden mice. In ApoE- - mice, the level of elastolysis was elevated compared to ApoE*3Leiden mice, and elastin breaks were found throughout the media, whereas in ApoE*3Leiden mice, elastolysis was confined to the IEL. This might explain the more prominent vascular remodeling in ApoE-/-Compared to ApoE* 3 Leiden mice.

Whether elastin degradation in the media is the cause for the development of compensatory enlargement, or the consequence, is still not clear. In favor of a causative role of elastin degradation are the recently published results of a study that showed that administration of a serine elastase inhibitor completely reverses fatal pulmonary remodeling in rats. ${ }^{46}$ in the present study, an increased amount of elastin breaks was already present in initial lesions, before significant compensatory enlargement develops, also indicating a causative role for media degeneration in the development of compensatory enlargement. The results of an elastin inhibitor in atherosclerosis will be awaited.

In conclusion, both ApoE- - - mice and ApoE*3Leiden mice are appropriate small animal models for studying vascular remodeling, especially in the carotid artery. For the investigation of the regulation of remodeling. ApoE-1- mice are more appropriate, since in this model, compensatory enlargement, stenosis, medial atrophy and elastolysis are most prominent. However, direct extrapolation to the human condition should be performed with caution, because some human features of vascular remodeling (such as poststenotic dilation and constrictive remodeling) are not observed in ApoE-f-.. or ApoE*3Leiden mice.

\section{Acknowledgements}

This project was sponsored by the Wynand Pon foundation, Leusden, the Netherlands. 


\section{Reterences}

1. Osler W (ed): Diseases of the arteries. Philadelphia, Lea and Febiger. 1908.

2. Topper JN, Cai J, Falb D. Gimbrone MA: Identification of vascular endothelial gene differentially responsive to fluid mechanical stimuli: eyclooxygenase-2. manganise superoxide dismutase. and enothelial cell nitric oxide synthase are selectively up-regulated by steady laminar shear stress. Proc Natl Acad Sci U S A 1996:93:10417-10422.

3. Stiel GM. Stiel LSG. Schofer J. Donath K. Mathey DG: Impact of compensatory enlargement of atherosclerotic coronary arteries on angiographic assessment of coronary artery disease. Circulation 1989:80:1603-1609.

4. Kiechl $\mathrm{S}$, Willeit J: The natural course of atherosclerosis. Part II: Vascular remodeling. Arterioscler Thromb Vasc Biol 1999;19:1491-1498.

5. Hermiller "JB, Tenaglia AN, Kissla KB, Philips HR, Bashore TM, Stack RS, Davidson CJ: In vivo validation of compensatory enlargement of atherosclerotic coronary arteries. Am $J$ Cardiol $1993 ; 71: 665-668$.

6. Losordo DW, Rosenfield K, Kaufman J, Pieczek A, Isner JM: Focal compensatory enlargement of muman arteries in response to progressive atherosclerosis. In vivo documentation using intravascular ultrasound. Circulation 1994;89:2570-2577.

7. Cullen $P$, Mohr $S$. Brennhausen B. Cignarella A, Assman $G$ : Downregulation of the selectin ligland-producing fucosyitransferases fuc-TV and fuc-TVIl during foam cell formation in monocyte-derived macrophages. Arterioscler Thromb Vasc Biol 1997;17:1591-1598.

8. Pasterkamp G. Borst C. Post M, Mali WPTM, Wensing PJW, Gussenhoven EJ, Hillen B: Atherosclerotic arterial remodeling in the superficial femoral artery. Individual variation in local compensatory enlargement response. Circulation 1996; $93: 1818-1825$.

9. Pasterkamp $G$, de Kleijn DPV. Borst $C$. Arterial remodeling in atherosclerosis, restenosis and atter alteration of bload flow: potential mechanisms and clinicall implications. Cardiovasc fies $2000 ; 45,843-852$

10. Armstrong ML., Heistad DD, Marcus ML, Megan MB. Piegors DJ: Structural and hemodynamic responses of peripheral arteries of Macaque monkeys to atherogenic diet. Arteriosclerosis 1985;5:336-346.

11. Clarkson TB, Prichard RW, Morgan TM Petrick GS, Klein KP: Remodeling of coronary arteries in human and nonhuman primates. JAMA 1994;271:289-294.

12. Kakuta T. Currier JW, Haudenschild CC. Ryan TJ, Faxon DP: Differences in compensatory vessel enlargement, not intimal formation, account for restenosis after angioplasty in the hypercholesterolemic rabbit model. Circulation 1994;89:2809-2815.

13. Post MJ, Borst $C$. Kuntz RE: The relative importance of arterial remodeling compared with intimal hyperplasia in lumen renarrowing after balloon angioplasty. Circulation 1994;89:2816-2821.

14. Carmeliet P. Moons L, Lijnen R. Baes M. Lemaitre V. Tipping P. Drew A. Eeckhout Y, Shapiro S. Lupu F. Collen D. Urokinase-generated plasmin activates matrix metalloproteinases during aneurysm formation. Nat Gen 1997;17:439-444.

15. Seo HS, Lombardi DM, Polinski P. Powel-Braxton L, Bunting S, Schwartz SM. Posenteld ME: Peripheral vascular stenosis in apolipoprotein E-deficient mice. Potential roles of lipid deposition, medial atrophy, and advantitial inflammation. Arterioscler Thromb Vasc Biol 1997; 17:3593-3601.

16. Bonthu S. Heistad DD, Chapell DA, Lamping KG. Faraci FM: Atherosclerosis, vascular remodeling. and impairment of endothelium dependent relaxation in genetically altered hyperlipidemic mice. Arterioscler Thromb Vasc Biol 1997;17:2333-2340.

17. Daugherty A, Manining MW. Cassis LA. Angiotensin II promotes atheroscierotic lesions and aneurysms in apolipoprotein E-deficient mice. J Clin invest 2000; 105:1605-1612.

18. Plump AS, Smith JD, Hayek T. Aalto-Setala K. Walsh A, Versituyft JG, Rubin EM, Bresiow JL: Severe hypercholesterolemia and atherosclerosis in apolipoprotein E-deficient mice created by homologous recombination in ES cells. Cell 1992;71:343-353.

19. Van Viimen BJ, van den Maagdenberg AM, Gijbels MJ, varn der Boom H, HogenEsch H. Frants FiA. Hofker MH. Havekes LM: Diet-induced hyperlipoproteinemia and atherosclerosis in apolipoprotein E3-Leiden transgenic mice. J Chin invest 1994:93(4):1403-1410.

20. van den Maagdenberg AM. Hofker MH, Krimpentort PJ. de-Bruijn I, van-Vilmen B, van der Boom H, Havekes LM. Frants RF: Transgenic mice carrying the apolipoprotein E3-Leiden gene exthibit hyperlipoproteinemia. J Biol Chem 1993,268: 10540-10545. 
21. Lutgens $E_{x}$ Daemen M, Kockx M. Doewendans $P$. Hofker M, Havekes $L$, Wellens $H$, de Muinck E: Atherosclerosis in APOE*3 Leiden transgenic mice: from proliferative to atheromatous stage. Cifrculation 1999:99:276-283.

22. Stary HC. Chandler AB, Dinsmore RE, Fuster $V$. Glagov $S$, Insull W Jr. Rosenteld ME, Sohwartz CJ. Wagner WD. Wissler RW: A definition of advanced types of atherosclentic lesions and a histological classification of atherosclerosis. A report from the Committee on Vascular Lesions of the Council on Arteriosclerosis. American Heart Association. Arterioscler Thromb Vasc Biol $1995 ; 15: 1512-1531$.

23. Glagov $S$, Weisenberg $E$. Zarins $C K$. Stankunavicius $R$, Koletis GJ: Compensatory enlargement of human atherosclerotic coronany arteries. NEJM 1987:316:1371-1375.

24. Kamiya A, Togawa T: Adaptive regulation of wall shear stress to flow change in the canine carotid artery. Am J Physiol 1980;239:H14-H21.

25. McPherson DD, Sirna SJ, Hiratzka LF, Thorpe L. Armstrong ML. Marcus ML. Kerber RE: Coronary arterial remadeling studied by high-frequency epicardial echocardiography: an early compensatory mechanism in patients with obstructive coronary atherosclerosis. I Am Coll Cardiol 1991;17:79-86

26. Nishioka T, Luo H. Eigler NL, Berglund H, Kim Cu. Siegel Rul: Contribution of inadequate compensatory enlargement to development of human coronary artery stenosis: an in vivo intravascular ultrasound study. J Am Coll Cardial 1996;27:1571-1576.

27. Mintz GS, Kent KM. Pichard AD. Satler LF. Popma JJ. Leon MB: Contribution of inadequate arterial remodeling to the development of focal coronary artery stenoses. An intravascular ultrasound study. Circulation 1997;95:1791-1798.

28. Pasterkamp G, Wensing PJW, Post MJ, Hillen B. Mali WPTM, Borst C: Paradoxical arterial wall shrinkage may contribute to luminal narrowing of human atherosclerotic femoral arteries. Circulation 1995;91:1444-1449.

29. van Kleef EM. Fingerle J. Daemen MJAP: Angiotensin II-induced progression of neointimal thickening in the balloon-injured rat carotid artery is ATI teceptor mediated. Arterioscier Thromb Wasc Biol 1996; 16:857-863.

30. Lamontagne $D$. Pohl U: Busse R: Mechanical deformation of vessel wall and shear stress determine the basal release of endothelium-derived relaxing factor in the intact rabbit coronary vascular bed. Circ Res 1992;70:123.

31. Hodgson J. Marshall J: Direct vasoconstriction and endothelium-dependent vasodilation. Mechanisms of acetylcholine effects on coronary flow and arterial diameter in patients with non* stenotic coronary arteries. Circulation 1989;79:1043-1051.

32. Zeiher AM, Drexler $H$, Wollschliager $H$, Just $H$. Modulation of coronary vasomotor tone in humans. Progressive endothelial dysfunction with different early stages of coronary atherosclerosis. Circulation 1991:83:391.

33. Vita JA, Treasure CB, Ganz P, Cox DA, Fish RD, Selwyn AP: Control of shear stress in the epicardial coronary arteries of humans: impairment by atheroscierosis. I Am Coll Cardiol $1989 ; 4: 1193-1199$.

34. Cox DA, Vita JA. Treasure CB, Fish RD. Alexander RW, Gamz P. Selwyn AP. Atherosclerosis impairs flow-mediated dillation of coronary arteries in humans. Circulation 1989;80:458-465.

35. Yang $\mathrm{P}$. Powell-Braxton L, Ogaowara AK, Dybodal N. Bunting S, Ohneda O. Jin H. Hypertension and endothelial dysfunction in apolipoprotein E knockout mice. Arterioscler Thromb Vasc Biol $1999 ; 19: 2762-2768$.

36. Deckert $V$. Lizard G. Duverger $\mathbb{N}$. Athias A. Palleau V. Emmanuel F, Moisant M. Gambert $P$, Lallemant C. Lagrost L: Impairment of endothelism-dependent relaxation by high fat feeding in ApoE-deficient mice. Toward normalization by human ApoA-1 expression. Circulation 1999:100:1230-1235.

37. Barton M, Haudenschild CC. d'Uscio LV. Shaw S. Munter K, Luscher T: Endathelin ETa receptor blockade restores $N O$-mediated endohelial lunction and inhibits atherosclerosis in apolipoprotein E deficient mice. Proc Natl Acad Sci US A 1998:95:14367-14372.

38. Wang $Y X$, Halks-Miller M, Vergona $R$, Sullivan ME, Fitch A, Mallari C. Martin-McNulty B, Da Cunha $V$. Freay A, Rubanyi GM, Kauser K: Increased aortic stiftness assessed by pulse wave velocity in apolipoprotein E-deficient mice. Am J Physiol 2000;278H4:28H H434.

39. Malek AM, Alper SL, Izumo Sl. Hemodynamic shear stress and its role in atherosclerosis. JAMA. $1999,282: 2035-2042$ 
40. Isrard RN. Pannier BM, Laurent S, London GM. Diebold B. Safar ME: Pulsatile diameter and elastic modulus of the aortic arch in essential hypertension: a noninwasive siudy. I Am Colf Cardiol 1989:13:399-405.

41. Mulvany MJ: Determinarits of vascular struciure. J Cardiovasc Phamacol 1992;19: S1-S6.

42. Crawiord T, Levene Ci: Medial thinning in atheroma. I Pathol 1953:66:19-23.

43. Anidjar S, Kieffer E: Pathogenesis of acquired aneurysms of the abdominal aorta. Ann Vasc Surg 1992:6:298-305.

44. Allaire $E$, Forough $R$. Clowes M. Starcher B. Clowes AW: Local overexpression of TIMP. 1 prevents aoric aneurysm ciegeneration and rupture in a rat model. J Clin Invest 1998;102:14131420.

45. Pyo R, Lee JK, Shipley JM. Curci JA, Mao D, Ziporin SJ, Ennis TL, Shapiro SD, Senior RM, Thompson RW: Targeted gene disruption of matrix metalloproteinase-9 (Gelatinase B) suppresses development of experimental abdominal aortic aneurysms. ' $A$ ' Clin invest $2000 ; 105: 1641-1649$

46. Northcote Cowan K. Heilbut A. Humpi T, Lam C. Ito S, Rabinowitch M: Complete reversal of fatal pulmonary hyperterision in rals by a serine elastase inhibitor. Mat Med 2000;6:698-702 


\section{Chapter 5}

Gas6-/-/ApoE-1- mice develop a collagen-rich, differently organized plaque phenotype, that is prone to intra-plaque hemorrhage

Esther Lutgens, Pablo Garcia de Frutos, Christina Apericio, Lieve Moons, Anique Janssen, Bjorn Dahlbäck, Désiré Collen, Mat Daemen and Peter Carmeliet.

Submitted

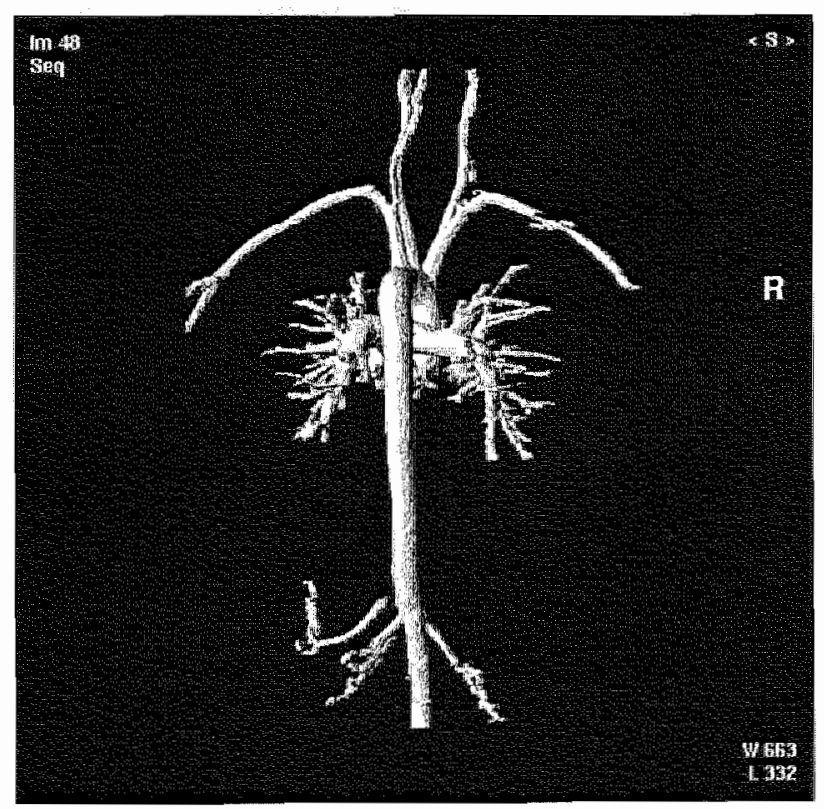




\section{Abstract}

To invesigate the role of Gas6 (growth arrest specific gene 6) in atherosclerosis. Gas6-1-1ApoE-1- mice were generated. Gas6-/-/ApoE-1- $(n=20)$ and ApoE-1$(n=24)$ mice were sacrificed after 23 wks on a normal chow or after 15 wks on a severely atherogenic diet. The aortic arch was taken oult for analysis. Plaque area and the number of plaques per aortic arch did not differ between both genotypes. Initial lesions of the non-diet and diet group showed a $7^{*}$ and $4^{*}$ increase in collagen content, and a $4.8^{*}$ and $4.1^{*}$ increase in SMC content, respectively. Effects of Gas6 deficiency in advanced lesions were more pronounced. In the non-diet group. Gas6- $/$ - A ApoE-1- mice showed a $21.2 \%$ and $30.1 \%$ decrease in macrophage and lipid core content. This was not observed in the diet group. Gas6-1-1ApoE-1- mice showed an increase in the number of lipid cores per lesion (2.1 vs 1.2 in ApoE-1non-diel group; and 3.2 vs 2.0 in ApoE-/-, diet group). Collagen content, as well as SMC content increased $2.2^{*}$ and $3.6^{*}$ in the non-diet group, and $1.3^{*}$ and $2.8^{*}$ in the diet group. In ApoE-l- mice, SMCs were confined to the shoulder and fibrous cap region, while in Gas6-1-/ApoE-1- mice, a significant amount of SMCs was also present in the lipid core region (23.6\% vs $0.8 \%$ ApoE-1- in the non-diet, and $19.4 \%$ vs $2.7 \%$ in ApoE-1- in the diet group). In the diet group, a significant decrease $\left(2.3^{*}\right)$ in T-lymphocyte content occurred. Interestingly, severe intraplaque bleeding. associated with iron deposition and fibrin formation, was observed in $11.1 \%$ of Gas6-1-/ApoE-1-mice of the nom-diet, and in up to $50 \%$ of the advanced lesions of the diet-group. In ApoE- $/$ - mice, this phenomenon was only observed in $4 \%$ of the advanced plaques of the diet group. In conclusion, absence of Gas 6 results in the development of a collagen/SMC rich, differently organized plaque phenotype. containing multiple lipid cores and prone to intraplaque hemorrhage. 
Gas6 (growth arrest-specific gene 6), was originally identified as a product of a gene, isolated by subtractive hybridization on the basis of preferential expression in the $G_{0}$ phase of the cell cycle. 'Further analysis revealed that Gas6 is a new member of proteins possessing $\gamma$-carboxyglutamic acid (GLA), that shares a $44 \%$ sequence homology with the anticoagulant factor protein $S .{ }^{2}$ However, Gas 6 does not exert the anti-coagulant function of protein $S$, most probably since it lacks the two thrombin cleavage sites of protein $S$.

Gas6 binds to members of the Axl family of receptor tyrosine kinases including Axl Sky and Mer, a family initiating several signaling cascades that determine a wide variety of phenotypic responses. ${ }^{3}$ Gas6 is expressed in many tissues, including lung, intestine, liver and the endothelium, and the expression of AxI. Sky and/or Mer is often overlapping. ${ }^{4}$ Therefore, it is postulated that Gas6 may exhibit diverse functions through three distinct receptors in a cell- and tissue-dependent manner.

The biological actions of Gas 6 are largely unknown. Most of the studies reported, indicate that Gas6 acts as a survival factor. ${ }^{1,5-7}$ Gas6 exerts ambivalent effects on cell turnover in the different cell types. For example, Gas6 is mitogenic in the presence of low serum for fibroblasts $s^{5,6}$, Schwann cells ${ }^{8}$, and enhances the mitogenic activity of thrombin in VSMCs ${ }^{2,9}$, but it is not mitogenic for myeloid cells ${ }^{10}$. or endothelial cells. ${ }^{11}$ A role for Gas6 in apoptosis is also postulated, since Gas6 plays a rolle in the cognition and clearing of dying cells by forming a bridge between phosphatidylserine on the surface of apoptotic cells and AxI on phagocytotic cells ${ }^{12}$

Recently, P. Carmeliet et al. reported that Gas6-/- mice are protected against venous and arterial thrombosis and collagen-induced thrombo-embolism, due to an impaired platelet aggregation. Gas6- $/$ - mice did, however, not suffer spontaneous bleeding and had a normal bleeding time. ${ }^{13}$

Interestingly, increased expression of Gas6 and Axl was observed after arterial balloon injury in rats, and in vitro studies reveal that Gas6 acts as achemoattractant for human and rat VSMCs. ${ }^{9.14}$ Furthermore, Gas6 inhibits granulocyte adhesion to TNF $\alpha$ stimulated endothelial cells ${ }^{11}$, and enhances the upregulation of scavenger receptor $A$, thereby contributing to foam cell formation inVSMCs in vitro. ${ }^{15}$

The phenomena described above play an important role in cardiovascular diseases, predominantly in atherosclerosis, suggesting an important role for Gas6 in atherogenesis also. Therefore, we generated mice deficient in Gas6 andApoE. Mice were led a normal chow diet or, to stress the phenotype, a severely atherogenic diet, containing $2 \%$ cholesterol and $0.5 \%$ cholate. Here we report that Gas6-1-/ApoE-1-mice develop a collagen rich, but disorganized plaque phenotype, and when stressed, massive intraplaque hemorrhage. 


\section{Materials and methods}

\section{Mice}

Inactivation of the Gas6 gene (Gas6+t) in embryonic stem (ES) cells was achieved by replacement of exons 1 and 2 with a neomycin phosphotransferase cassette. Correct targeting was confirmed by Southern blotting. Targeted ES cells were used for generation of chimeric mice and subsequent germline transmission. Apparently healthy Gas6 $+1-$ and Gas6-1- mice were born according to Mendelian inheritance. To generate Gas6-/ApoE-/- mice, Gas6-1- mice were backcrossed to C57Bi6 mice, and crossed to ApoE-f- mice.

\section{Experimental protocol}

Gas6-1-AApoE-I- $(n=12)$ and ApoE-/- mice $(n=12)$ of the non-diet group were fed a normal chow diet for 23 wks, while the diet group, consisting of $n=8$ Gas6-1-1ApoE-1- and $n=12$ ApoE-/- mice, received a severely atherogenic diet ( $2 \%$ cholesterol, $0.5 \%$ cholate) for 15 wks from the age of 5 wks. Two weeks before the end of the experimental period, 5'-bromo-2'-deoxyuridine BrdU. Serva Heidelberg. Germany, infusion rate $13 \mathrm{mg} / \mathrm{kg}$.day) was infused using osmotic minipumps (Alzet, 2001) in $n=5$ animals per group. After the experimental period, mice were sacrificed, the arterial tree was excised, and the tissue was processed as described earlier. ${ }^{16.17}$

\section{Lipid Profile}

Plasma cholesterol levels were determined in duplicate by usingcolorimetric assays (CHOD-PAP 1442341; Boehringer Mannheim).

\section{Histomorphometry}

For histo-morphological analysis, the aortic arch, including its main branchpoints, was used (fig 5.2a). Atherosclerotic lesions were divided into initial lesions (fatty streak lesions) and advanced lesions (with a lipid core and/or fibrous cap), according to the AHA classification. ${ }^{18}$ Additionally, advanced lesions of the dietgroup were subdivided into small $\left(<75,00 \mathrm{qu} \mathrm{m}^{2}\right)$ and large $\left(>75,000 \mu \mathrm{m}^{2}\right)$ advanced lesions. Analysis of histo-morphological parameters was performed as described earlier. ${ }^{16.17}$

\section{(Immuno)histochemistry}

For gross histological analysis and morphometry, sections were stained with haematoxilin and eosin (HE) and Lawson solution. Sirius red staining was performed to detect collagen, and Perls iron staining was used to detect iron.

Sections were immunolabeled with $\alpha$-smooth muscle actin (ASMA FIT, monoclonal 1:3000, Sigma Chemical Co) as a marker for smooth muscle cells and fibroblasts, ED1 (1:10) for the detection of macrophages, CD3 (CD3 polyclonal, 1:200, Dako A0452) for the detection of T-lymphocytes, anti-fibrin (goat monoclonal mouse antibody; 1:800. P. Carmeliet), anti-Gas6 and anti-Axl (both 1:100, P. Garcia de Frutos), anti-BroU (Mas 250b, Harlan sera labs) for the detection of DNAsynthesizing cells and TUNEL (Boehringer Mannheim) for the detection of apoptosis as described previously. ${ }^{16.17}$ 
Statistical analysis

Data are expressed as meantSEM. Gas6-/-/ApoE-/- mice were compared with ApoE-1- mice, using a non-parametric Mann-Whitney $U$ test. The level of statistical significance was set at $p<0.05$.

\section{Results}

\section{General}

Body weight, as well as heart weight did not differ between both mouse models. Gross histological analysis (HE staining) did not reveal any abnormalities in liver and spleen, especially no signs of bleeding.

In the non-diet group, cholesterol levels did not differ (Gas6-/-IApoE-I-: $7.5 \pm 0.4 \mathrm{mmol} / \mathrm{L}$, ApoE- $-1-: 7.0 \pm 0.3 \mathrm{mmol} / \mathrm{L}$ ). In the diet group, cholesterol levels were significantly decreased in Gas6-/ApoE-/- mice $(30.3 \pm 3.3 \mathrm{mmol} / \mathrm{L}$ vs $39.3 \pm 1.9 \mathrm{mmol} / \mathrm{L}, \mathrm{p}<0.05)$.

\section{Gas6 and Axl immunolocalisation}

Gas6 was present in the atherosclerotic lesion as well as in the normal vessel watl. In the normal vessel wall. Gas6 was confined to the endothelium, whereas in the atherosclerotic lesion, Gas6 immunoreactivity could be observed in the endothelium, plaque SMCs and in some, but not all, macrophages.

Axl immunoreactivity was confined to the atherosclerotic lesion. Axl was present at the endothelium, in all macrophages, and in some of the plaqueSMCs.

\section{Non-diet group}

In total, 49 lesions in the aortic arch of Gas6-/-/ApoE-1- $(n=12)$ and 49 lesions of ApoE- $/-$ mice $(n=12)$ were analyzed. Total plaque area $\left(174,057 \pm 119,453 \mu \mathrm{m}^{2}\right.$ in Gas6-/-/ApoE-/- vs 122,161 $\pm 50.971 \mu \mathrm{m}^{2}$ in ApoE-/-), as well as individual initial $\left(11,873 \pm 1,595 \mu \mathrm{m}^{2}\right.$ vs $9,862 \pm 1640 \mu \mathrm{m}^{2}$ in $\left.\mathrm{ApoE}-/-\right)$ and advanced plaque area $\left(46,734 \pm 9,223 \mu \mathrm{m}^{2}\right.$ vs $79,111 \pm 13,830 \mu \mathrm{m}^{2}$ in ApoE-1-), or the number of plaques

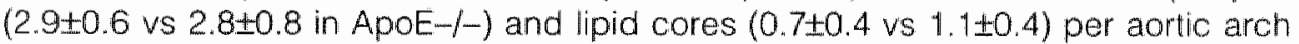
did not differ between both genotypes.

Initial lesions

Besides a 7 fold increase in collagen-content (fig 5.1a), absence of Gas6 showed no profound effects on initial lesion morphology. Relative ASMA content (fig 5.1b), macrophage content $(72.8 \pm 2.6$ vs $67.9 \pm 2.9 \%$ ) as well as T-lymphocyte content (fig 5.1 ) were not different after genetic disruption of Gas6.

\section{Advanced lesions}

In contrast to initial lesions, advanced lesions of Gas6-/-IApoE-/- mice exhibited a completely different plaque composition compared to ApoE-/- mice. Collagen content and ASMA content increased 2.2 fold and 3.6 fold (fig 5.1a-b). However, this did not result in an increased fibrous cap thickness. In Gas6-/-IApoE-/-mice, ASMA-positive cells were distributed throughout the lesion $(38.6 \%$ of all ASMA positive cells in the shoulder region, $23.6 \%$ in the lipid core region, $37.8 \%$ in the 
a

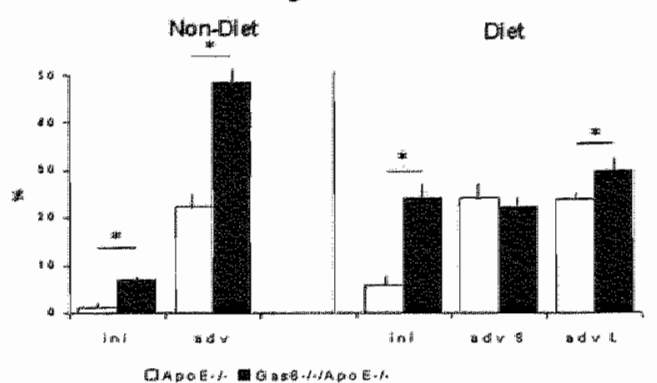

b

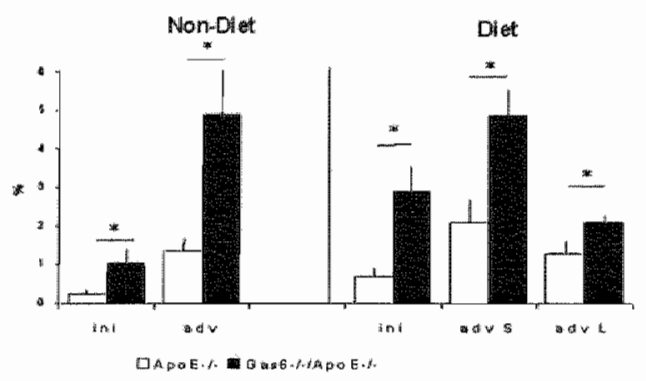

Lipid core content

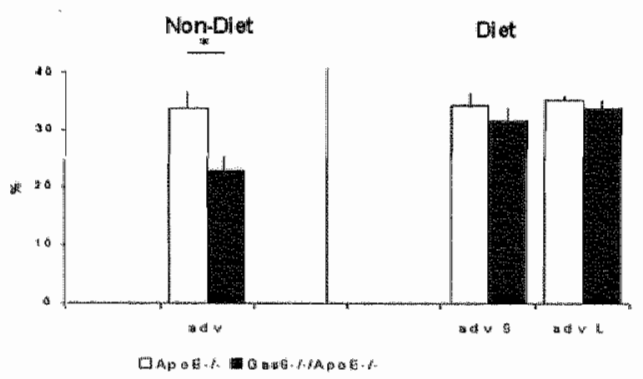

d

\# Lipid cores/Lesion

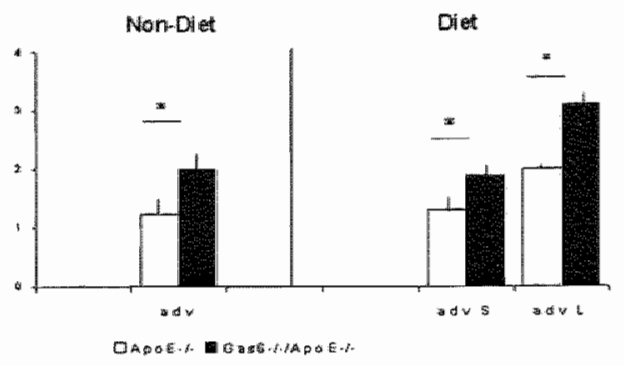

랑

T-Lymphocyte content

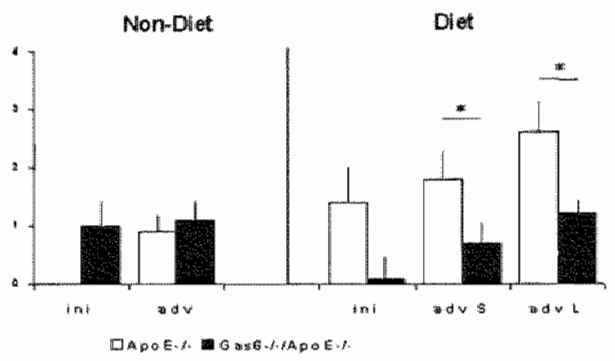

Intraplaque hemomhage

Non-Diet

Dit

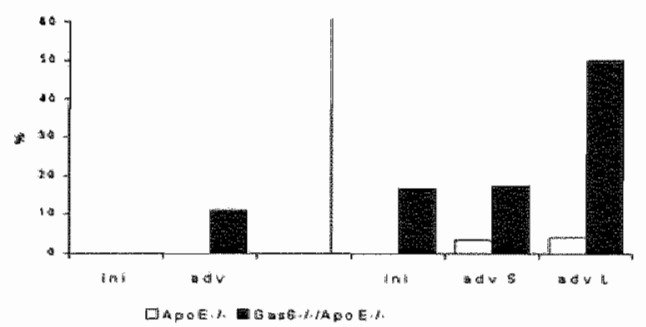

Fig. 5.1

Graphs showing plaque characteristics of Gas6-//ApoE-/- and ApoE-/- mice of the non-diet and diet groups showing (a) collagen content, (b) ASMA content, (c) lipid core content, (d) the number of lipid cores per lesion, (e) T-lymphocyte content and (f) the degree of intra-plaque hemorhage. 
fibrous cap region), while in ApoE-/- mice, ASMA positive cells were confined to the shoulder region (36.3\%) and fibrous cap region (62.9\%). Furthermore, polarization microscopy revealed the presence of increased amounts of immature collagen in Gas6-/-/ApoE-/- mice.

In Gas6-/-/ApoE-/- mice, macrophage content (42.8 $\$ 5.1 \%$ vs $54.1 \pm 3.0 \%$ in ApoE-l-) and lipid core content decreased (fig 5.1c), while T-lymphocyte content was not affected (fig 5.1e). Interestingly, besides a decrease in lipid core content, the number of lipid cores was significantly increased in Gas6-/-/ApoE-/- mice (fig 5.1d). These results reveal an inhibitory effect of Gas6 deficiency on macrophage infiltration and lipid core formation, although fibrous cap and lipid core seem to develop in a differently organized way.

\section{Diet group}

In the diet group, 72 lesions of Gas6-1-/ApoE-1- mice and 121 lesions of ApoE-1mice were analyzed. As in the non-diet group, no differences were found in total plaque area $\left(1,205,779 \pm 146,540 \mu^{2}\right.$ vs $1,152157 \pm 136,035 \mu \mathrm{m}^{2}$ in ApoE-l-). individual initial $\left(32,742 \pm 18,233 \mu \mathrm{m}^{2}\right.$ vs $20,452 \pm 4,232 \mu \mathrm{m}^{2}$ in ApoE- - - $)$ and advanced $\left(185,431 \pm 20,232 \mu \mathrm{m}^{2}\right.$ vs $191,076 \pm 17398 \mu \mathrm{m}^{2}$ in ApoE-l- $)$ plaque area or the number

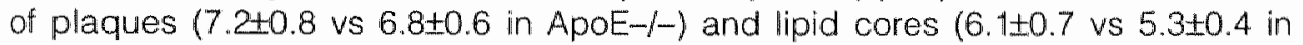
ApoE-l-) per aortic arch.

\section{Initial lesions}

As observed in the non-diet group, initial lesions of the diet group showed a 4.0 fold increase in collagen content and in addition, a 4.1 fold increase in SMC content (fig. 5.1a-b). Other parameters, like macrophage content (65.3t6.7\% vs $68.0 \pm 3.7 \%$ in ApoE- $/$-) and T-lymphocyte content did not differ between both genotypes (fig 5.10 ).

\section{Advanced lesions}

Advanced atherosclerotic lesions of the diet group were divided into small (AS) and large (AL) atherosclerotic plaques. As in the non-diet group, lesions exhibited a 0.9 (AS) and 1.3 (AL) fold increase in collagen content and a 2.2 (AS) and 1.6 fold (AL) increase in ASMA content (fig 5.1a-b and fig 5.2b-e). Also in the Gas6-1-/ApoE-1diet group. ASMA positive cells were distributed equally throughout the lesion (AS: $54.6 \%$ shoulder, $32.1 \%$ fibrous cap, $13.3 \%$ lipid core; AL $36.1 \%, 44.4 \%$ and $19.4 \%$ respectively), while in ApoE-1- mice, hardly any ASMA positive cells could be observed in the lipid core region (AS: 1.3\%, AL: 2.7\%) (fig 5.2d-e). Again, polarization microscopy revealed an increased presence of immature collagen in Gas6-/-/ApoE-/- mice.

Although Gas6 deficiency in the non-diet group inhibited lipid core formation and macrophage influx, these effects were probably masked by the severely atherogenic diet (fig. 5.1c). However, the number of lipid cores/lesion in advanced plaques of the diet group increased even more (fig. $5.1 \mathrm{~d}$ and fig $5.2 \mathrm{f}-\mathrm{g}$ ). Interestingly, in both small and large advanced lesions of the diet group. Tlymphocyte content decreased 2.6 and 2.2 fold respectively (fig. 5.1e).

These results reveal that absence of Gas6 results in a differently organized plaque phenotype that is rich in collagen and SMCs. 

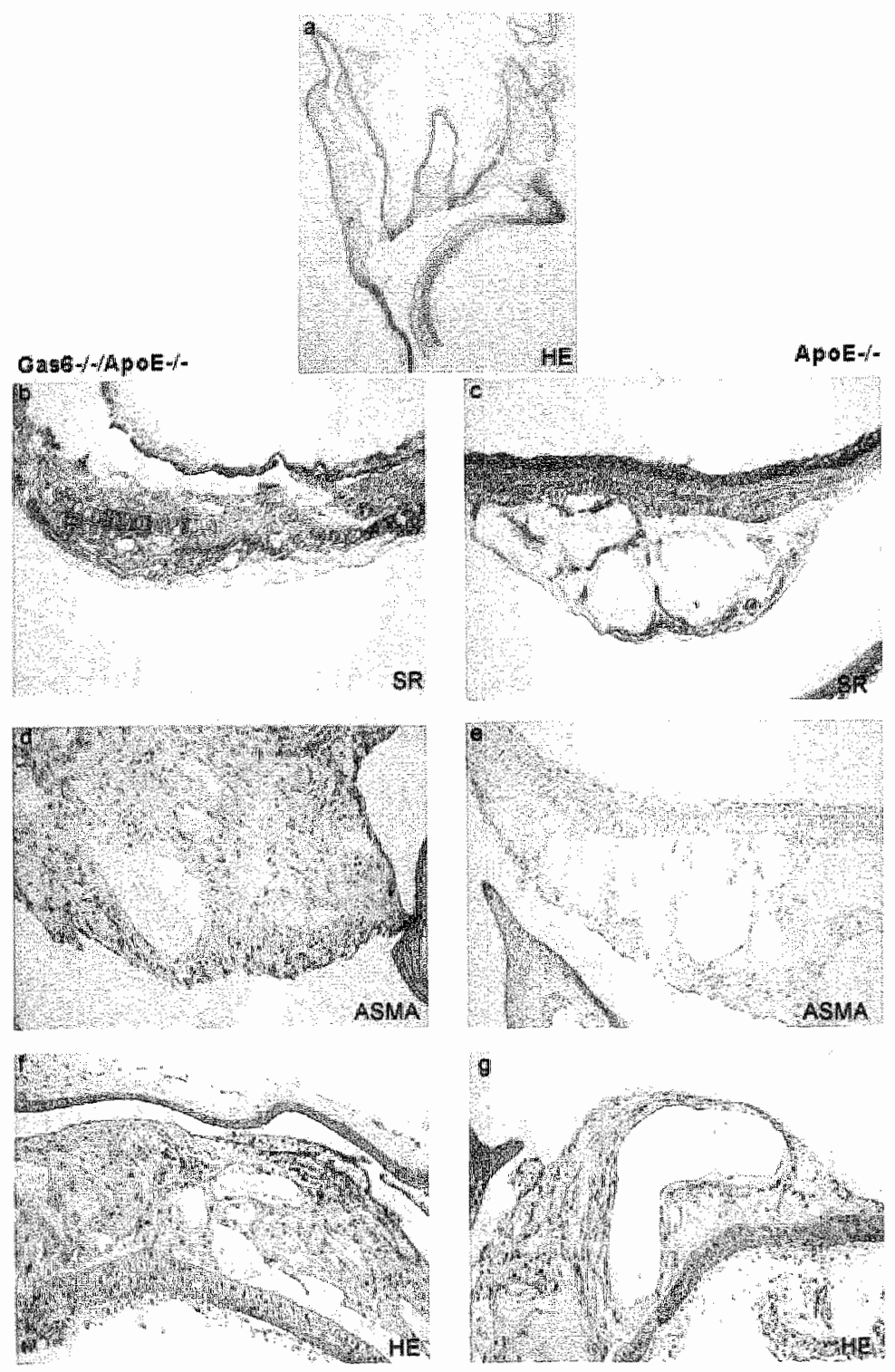

Fig. 5.2

Histological characteristics of Gas6-1-1ApoE-1- and ApoE-1- mice. (a) HE staining of a longitudinal section of the aortic arch, including its main branchpoints (brachiocephalic trunk, left carotid artery and left subclavian artery) of an ApoE $\%$ - mouse. (b and c) Sirius Red staining of an advanced lesion of a Gas6-/ApoE-/- and ApoE-w/- mouse, revealing increased collagen content in the Gas6-1-/ApoE-1- mouse (d and e) ASMA staining of an advanced lesion a Gas6-/APoE-1- and ApoE-1- mouse, revealing increased ASMA immunoreactivity in Gas6-1-1ApoE-1- mouse. Interestingly, in the Gas6-/APoE-1- mouse. ASMA positive cells were distributed throughout the lesion, while in the ApoE-/w mouse, ASMiA positive cells were confined to the fibrous cap. (f and $g$ ) HE staining of an advamced lesion a Gas6-/ $/$ ApoE- $/$ - and ApoE- $/$ - mouse, revealing a differently organized atherosclerotic lesion, with an increased number of lipid cores in the Gas6-1-/ApoE-1mouse. 

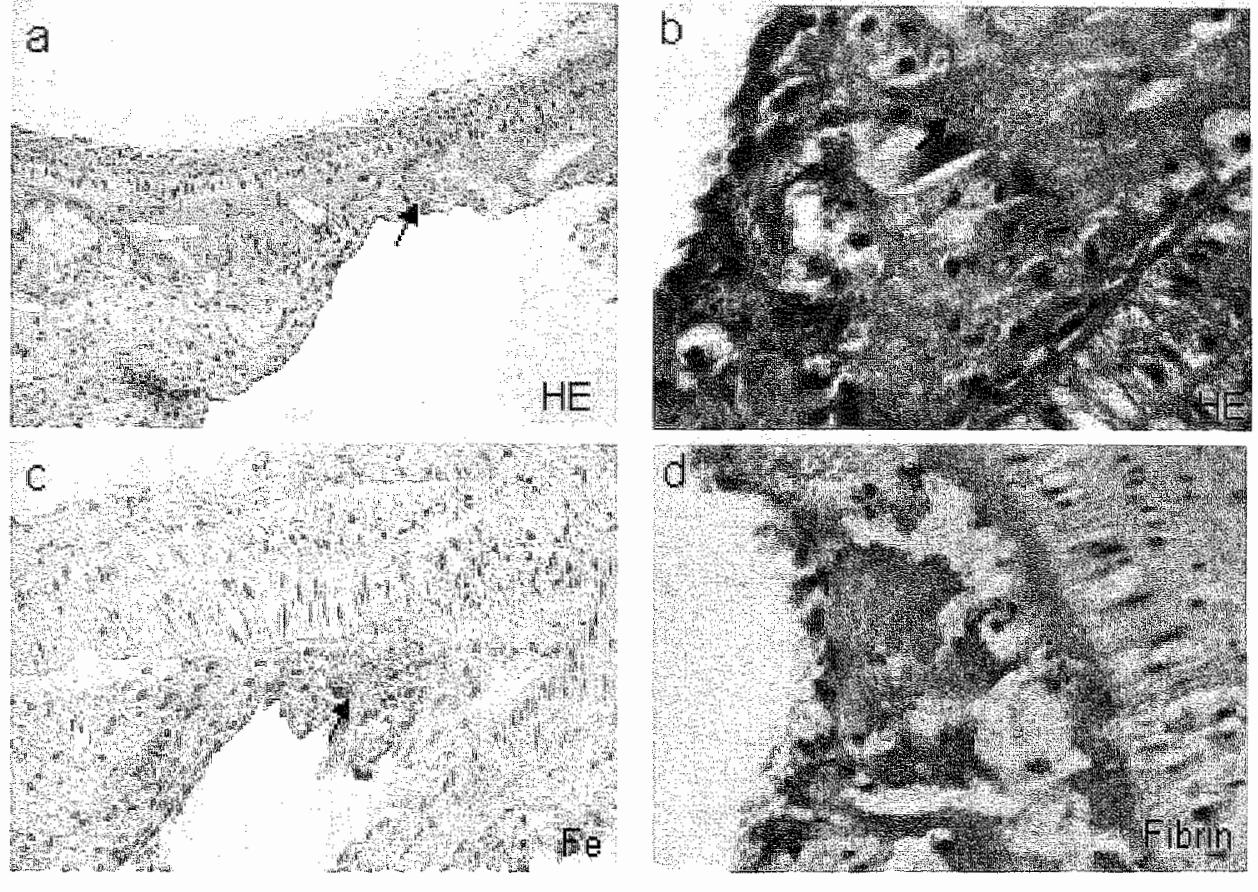

\section{Fig. 5.3}

(a) HE staining revealing severe intra-plaque hemorrhage at the shoulder region of an advanced atherosclerotic lesion of a Gas6-/ApoE-/- mouse. (b) Intraplacue hemorrhage in detail, the individual erythrocytes can be appreciated. (c) Perl's iron staining iron deposition. (d) Fibrin staining showing fibrin formation.

\section{Cell turnover parameters}

Since it is postulated that Gas6-Axl interactions play a role in survival, mitogenic and apoptotic activities, we investigated the level of DNA-synthesis and apoptosis in advanced and initial atherosclerotic plaques.

Interestingly, absence of Gas6 did not affect cell turnover parameters to a large extent. In initial and advanced lesions of the non-diet group, levels of DNA-synthesis (initial lesions: $5.9 \pm 2.1 \%$ vs $6.3 \pm 3.3 \%$ in ApoE- $/$; advanced lesions: $3.1 \pm 1.7 \%$ vs $2.9 \pm 1.4 \%$ in ApoE-1-; p >0.05) and apoptosis (initial lesions: $0.4 \pm 0.2 \%$ vs $0.4 \pm 0.3 \%$ in ApoE-1-; advanced lesions: $1.3 \pm 0.7 \%$ vs $1.2 \pm 0.2 \%$ in ApoE-l-; $p>0.05$ ) did not differ between both genotypes. In the diet group, no differences in cell turnover parameters were observed in initial (DNA-synthesis: $6.8 \pm 2.4 \%$ vs $8.7 \pm 2.8 \%$ in ApoE-1-; Apoptosis: $0.3 \pm 0.3 \%$ vs $0.5 \pm 0.2 \%$ in ApoE-1-; $p>0.05$ ) and small advanced lesions (DNA-synthesis: $6.2 \pm 2.0 \%$ vs $4.2 \pm 0.8 \%$ in ApoE-1-; Apoptosis: $0.5 \pm 0.2 \%$ vs $0.8 \pm 0.3 \%$ in ApoE-1-; p $>0.05$ ) of both mouse models. Only in advanced large atherosclerotic lesions, absence of Gas6 induced a significant increase in DNA-synthesis (5.6 $0.8 \%$ vs $3.9 \pm 0.4 \%$ in ApoE-l-) and a decrease in 
apoptosis $(0.8 \pm 0.1 \%$ vs $1.3 \pm 0.2 \%$ in $A$ poE $-1-; p<0.05)$. This probably reflects the repair process after intra-plaque hemorrhage.

\section{Intra-plaque hemorrhage}

The most remarkable finding of this study was the occurrence of intraplaque hemormage. In Gas6-/ApoE-/- mice of the non-diet group, this was abserved in 3 out of 27 advanced plaques, while in ApoE-1- mice, this phenomenon was not observed at all. In the diet group, massive intraplaque hemorrhage occurred in 3 out of 16 initial lesions, in 4 out of 23 small advanced plaques, and in 15 out of 30 large advanced plaques (fig. $5.3 \mathrm{a}$ and $5.3 \mathrm{~b}$ ). Furthermore, $>60 \%$ of the intraplaque hemorrhages was associated with fibrin and iron deposition (fig. $5.3 \mathrm{c}$ and $5.3 \mathrm{~d}$ ).

\section{Discussion}

This manuscript is the first to describe the in vivo role of Gas6 during atherogenesis. It reveals that absence of Gas6 results in the development of a collagen rich, but differently organized plaque phenotype. The most remarkable finding of this study is the occurrence of severe intraplaque hemorrhage, associated with iron deposition that, to our knowledge, has never been described before in mice.

In humans, intraplaque hemorhage is associated with an unstable plaque phenotype, prone to rupture and responsible for most of the acute complications of atherosclerosis. ${ }^{19,20}$ Other parameters of an instable plaque phenotype are a reduced collagen/VSMC content, large lipid cores and massive T-lymphocyte infiltration. ${ }^{18,21}$ Interestingly, these phenomena were not observed in Gas6-/-/ApoE-1- mice. In these mice, collagen content even increased, and when stressed. T-lymphocyte content decreased, indicating a rather stable plaque phenotype. However, although collagen and VSMC content were increased, they did not cause an increase in fibrous cap thickness. Further analysis revealed that increased amounts of immature forms of collagen were present, and that VSMCs were distributed equally throughout the entire lesion, indicating rather a disorganized plaque phenotype. In addition, lipid cores of Gas6-/ApoE-/- mice were composed of multiple small lipid cores.

Postulated mechanisms of the development of the disorganized plaque phenotype, and subsequent intraplaque hemorrhage are a decreased cell-cell adhesion and a disturbance in tissue organization. The receptor for Gas6, the tyrosine kinase receptor $A \mathrm{Al}_{\text {: }}$ is a transmembrane protein, whose extracellular domain resembles that of many cell adhesion molecules. ${ }^{22}$ In insect cells and mammalian cell lines in vitro, overexpressing of the murine homologue of Axl. ARK results in a the formation of cell-aggregates. ${ }^{23}$ Furthermore, myeloid cells expressing $A x \mid$ exhibit increased aggregation in response to Gas6 treatment, indicating a role for Gas6-Axl interactions in cell-cell adhesion. ${ }^{24}$ it is also reported that Gas6 plays a role in leukocyte-endothelial cell interactions. Although Gas6 did not affect adhesion of granulocytes to resting endothelial cells, it inhibited granulocyte adhesion to TNF $\alpha$ activated endothelial cells. "However, to obtain this effect, high doses of Gas6 were required and the relevance of this study remains questionable." 
During embryogenesis, Axl is expressed from embryonic day 12.5, and is found particularly in mesodermal structures. ${ }^{25}$ it might therefore play a role in the development and maintenance of mesenchymal organ structure.

Besides impaired cell-cell adhesion, and disturbances in tissue organization, impaired coagullation could also contribute to intra-plaque hemorrhage observed in Gas6-/-/ApoE-1- mice. Interestingly, Gas6 antibodies significantly inhibit platelet aggregation in vitro. Furthermore, Gas6-1- mice are protected against venous and arterial thrombosis and against fatal collagen-induced thrombo-embolism. ${ }^{13}$

DNA-synthesis and apoptosis, as well as migration of VSMCs are thought to be important features in atherosclerosis and restenosis. ${ }^{16,26,27}$ In these processes, expression of growth factors or vasoactive substances, that signal through receptor tyrosine kinases, such as PDGF, FGF, angiotensin II and thrombin play a major role. ${ }^{28}$ It is therefore postulated that Gas6, a ligand for the receptor tyrosine kinase Axl, can exert mitogenic, survival, apoptotic or migratory properties in cardiovascular diseases. Here, we report that absence of Gas6 exerts only little effects on cell turnover parameters. Gas6-1-/ApoE-1- mice exhibit a slight, but significant increase in DNA-synthesis and a decrease in apoptosis, but only in the advanced large lesions of the diet-group. Furthermore, the increased SMC content observed in plaques of Gas6-I-/ApoE-1- mice might reflect increased migration of SMCs.

Other studies, performed after balloon injury in rats, showed that both Gas6, and its receptor AxI were upregulated, with peak expression 7 and 14 days after arterial injury. ${ }^{14}$ Gas6 did not result in increased VSMC proliferation, but it induced AxImediated chemotaxis of VSMCs. ${ }^{9,14}$ In contrast with these results, we show that Gas6 deficiency might induce an increased VSMC migration. This discrepancy can be explained by the fact that the pathogenesis of primary atherosclerosis and restenosis is different.

Another feature, important in the pathogenesis of atherosclerosis, is the increased uptake of oxLDL by macrophages and VSMCs, resulting in foam cell formation. ${ }^{20}$ The receptor, responsible for the uptake of oxLDL is the scavenger receptor. ${ }^{29}$ In literature, it is reported that Gas6 induces the upregulation of scavenger receptor $A$ in VSMCs in vitro, thereby postulating a role for Gas6 in foam cell formation. ${ }^{15}$ Consistent with these results, we report that absence of Gas6 reduces lipid core content and macrophage content in mice fed a normal chow diet.

In conclusion, we report that Gas6 plays an important role during atherogenesis, and since its absence induces a differently organized, hemorrhage prone plaque phenotype, we postulate that Gas6 is responsible for the maintenance of cell-cell contact and cell organization in the atherosclerotic lesion. In addition. Gas6 deficiency might induce impaired platelet aggretion in atherosclerotic lesions, and might consequently induce severe intraplaque hemorrhage. To our knowledge, this is the first atheroscierotic mouse model that exhibits intra-plaque hemorrhage. Although even in these mice, rupture of the fibrous cap with luminal thrombus formation did not occur, this animal model may provide clues that are also important in human plaque destabilisation. 


\section{Feferences}

1. Schneider C. King RM, Phillipson L: Genes specifically expressed at growth arrest of manmalian cells. Ceell 1988;54:787-793.

2. Nakano $T$, Kawamoto $K$, Kishino J. Nomura $K$. Hagashino $K C$, Arita $H$ : Requirement of $y-$ carboxyglutamic acid residues for the biological activity of gas6: contribution of endogenous gas6 to the proliferation of vascular smooth muscle cells. Biochem J 1997:323:387-392.

3. Stit TN: The anticoagulation factor protein $S$ and its relative, gas6, are ligands for the Tyro $3 / A x$ l family of receptor tyrosine kinases. Cell 1995;80:661-670.

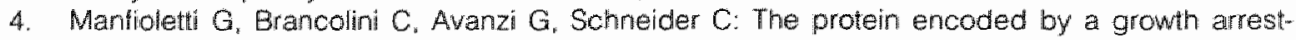
specific gene (gas6) is a new member of the vitamin K-dependent proteins related to protein $S$. a negative coregulator in the blood coagulation cascade. Mol Cell Biol 1993:13:4976-4985.

5. Bellosta $P$, Zhang $Q$, Goff SP. Basilico C: Signaling through the ARK tyrosine kinase receptor protects trom apoptosis ir the absence of growth stimulation. Oncogene 1997; 15:2387-2397.

6. Goruppi S, Ruaro E. Schneider C: Gas6, the ligand of Axl tyrosine kinase receptor has mitogenic and survival activities for serum starved NIH3T3 fibroblasts. Oncogene 1996;12:471. 480.

7. Lee WP, Liao Y. Robinson D. Kung HJ. Liu ET, Hung MC: Axl-Gas6 interaction counteracts E1Amediated cell growth suppression and pro-apoptotic activity. Mol Cell Biol 1999"19:8075-8082.

B. Li R. Chen J, Hammonds G, Philips H. Armanini M, Wood P. Bunge R, Godowski PJ, Sliwkowski MX, Mather JP: Identification of Gas6 as a growth factor for human Schwann cells. Neurosci Lett $1996 ; 16: 2012-2019$

9. Fridell YWC, Villa J, Attar EC, Liu ET: GAS6 induces Axl-mediated chemotaxis of vascular smooth muscle cells. I Biol Chem 1998:273:7123-7126.

10. Avanzi GC, Gallichio M, Cavalloni G, Gammaitoni L, Leone F, Rosina A. Boldorini R, Monga G. Pegoraro L, Varnum B. Aglietta M: Gas6, the ligand of Axl and Rse receptors, is expressed in hematopoietic tissue, but lacks mitogenic activity. Exp Hematol 1997:25:1219-1226.

11. Avanzi GC, Gallicchio M, Bottarel F, Gammaitoni L, Cavalloni G, Buonfiglio D. Bragardo $M_{\text {, }}$ Bellomo G, Albano E. Fantozzi R. Garbarino G, Varnum B. Aglietta M. Saglio G. Dianzani U. Dianzani C: GAS6 inhibils granulocyte adhesion to endothelial cells. Blood 1998:91:2334-2340.

12. Nakano $T$, Ishimoto $Y$, Kishino J, Umeda $M$, Inoue $K$, Nagata $K$, Ohashi $K$, Mizuno $K$, Arita $H$ : Cell adhesion to phosphatidylserine mediated by a product of growth arrest specific gene 6 . J Biol Cherm 1997;272:29411-29414.

13. Angellilo-Scherrer A, Garcia de Frutos P. Aparicio C, Melis E, Savi P, Lupu F. Arnout $\rrbracket_{\text {, Dewerchin }}$ M. Hoylaerts MF. Herbert JM, Collen D, Dahibäck B and Carmeliet P: Deficiency or inhibition of Gas6, a homologue of the anticoagulant Protein $\mathrm{S}$. protects mice against thrombosis by impairing platelet aggregation. Submitted.

14. Melaragno MG. Wuthrich DA, Poppa V. Gill D, Lindner $V$. Berk BC, Corson MA: Increased expression of Axl tyrosime kinase after vascular injury and regulation by $G$ protein-coupled receptor agonists in rats. Circ Res 1998;83:697-704.

15. Murao K, Imachi H, Sayo $Y$, Hosokawa $H$, Sato M, Ishida $T$. Nakano T, Kodama T, Sasaguri $Y$, Takahara J: A product of growth arrest-specitic gene 6 modulates scavenger receptor expression in human vascular smooth muscle cells. FEBS letters 1999;459:363-366.

10. Luigens $E$, Daemen $M$. Kockx M. Doevendans P. Hofker M. Havekes L. Wellens $H$, de Muinck E: Atherosclerosis in APOE*3 Leiden transgenic mice: from proliferative to atheromatous stage. Circulation 1999:99:276-283.

17. Lutgens $E$. Gorelik L, Daemen MJAP. de Muinck ED. Grewal IS, Kotelianski VE. Flavell RA: Fequirement for CD154 in the progression of atherosclerosis. Nat Med 1999:5:1313-1316.

18. Stary HC. Chandler AB, Dinsmore RE, Fuster V. Glagov S, Insull W Jr, Rosenteld ME, Schwartz CJ. Wagner WD, Wissler RW: A definition of advanced lypes of atherosclerotic lesions and a histological classification of atherosclerosis. A report from the Committee on Vascular Lesions of the Council on Arteriosclerosis, American Heart Association. Arterioscler Thromb Vasc Biol $1995 ; 15: 1512-1531$

19. Libby P. Mach F. Schonbeck U. Bourcier T. Aikawa M. Regulation of the thrombotic potential of aheroma. Thromb Haem 1999:82:736-741.

20. Ross R: Atherosclerosis. An inflammatory disease. NEJM 1999;340:115-126.

21. Libby P: Molecular bases of the acute coronary syndromes. Circulation 1995;91:2844-2850. 
22. Willams AF, Barclay AN: The immunoglobulin superfamily domains for cell sufface recognition. Annu Rev Immunol 1988;6:381-405.

23. Bellosta P. Costa M. Lin DA. Basilico C: The receptor tyrosine kinase ARK mediates cell aggregation by homophilic binding. Mol Cell Biol 1995; 15:614-625.

24. McCloskey P, Fridell YW. Attar E, Villa J, Jin Y. Varmum B. Liu ET: GAS6 mediates adhesion of cells expressing the receptor kinase Axl. J Biol Chem 1997, 272:23285-23291.

25. Faust M, Ebensperger M, Schulz AS, Scheithoff L. Hameister H. Bartram CR, Janssen IWG: The murine ufo receptor: molecular cloning, chromosomal localisation and in situ expression analysis, Oncogene 1992:7:1287-1293.

26. Lutgens E, de Muinck ED, Kitslaar PJEHM, Tordoir JHM, Wellens HJJ, Daemen MJAP: Biphasic pattern of cell turnover characterizes the progression from latty streaks to ruptured human atherosclerotic piaques. Cardiovasc Res 1999;41:473 379 .

27. Schwartz SM, de Blois D. O'Brien ERM: The intima. Soil for atherosclerosis and restenosis. Circ Res 1995:77:445-465.

28. Berk BC, Corson MA: Angiotensin ll signal transduction in vascular smooth muscle. Role of tyrosine kinases. Circ Res 1997:80:607-616.

29. de Winther MPJ. Willems van Dijk K. Havekes LM, Hotker MH: Macrophage scavenger receptor class A. A multifunctional receptor in atherosclerosis. Arterioscler Thromb Vasc Biol 2000;20:290-297. 


\section{Chapter 6}

Requirement for CD154 in the progression of atherosclerosis

Esther Lutgens, Leonid Gorelik, Mat Daemen, Ebo de Muinck, lqbal Grewal, Victor Koteliansky and Richard Flavell

Nat Med 1999;5:1313-1316

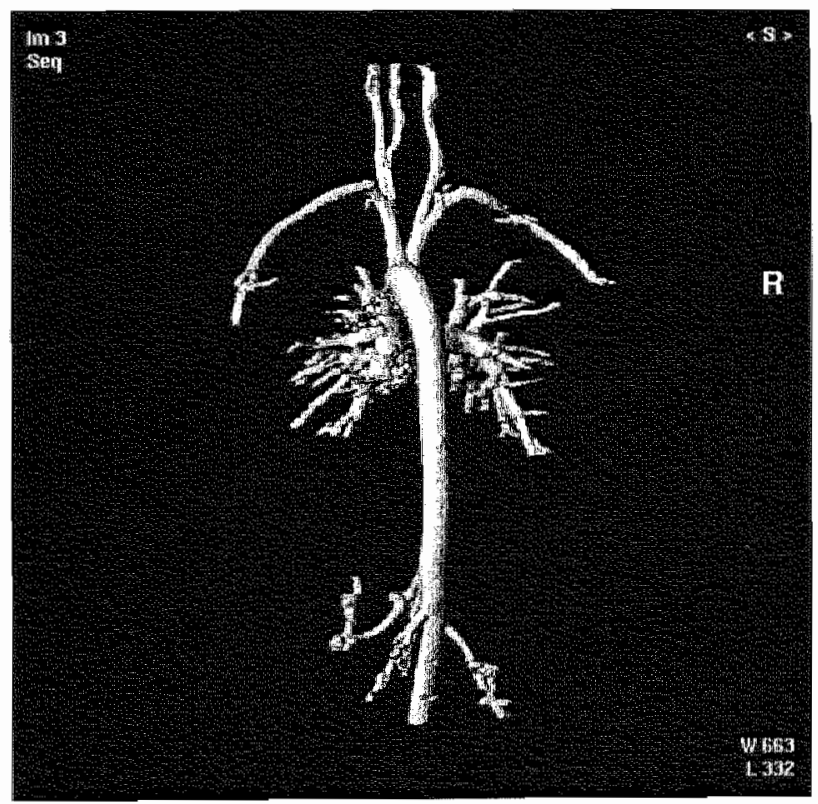





\section{Abstract \& Introduction}

Atherosclerosis is a systemic disease of the large arteries, and activation of inflammatory pathways is important in its pathogenesis. Increasing evidence supports the importance of CD40-CD154 ( $=$ CD40L) interactions in atherosclerosis ${ }^{2,3}$, interactions originally known to be essential in major immune reactions and autoimmune diseases. ${ }^{5} \mathrm{CD} 40$ is present on atheromanderived cells in vitro and in human atheromata in situ. ${ }^{6}$ Ligation of CD40 on atheroma-associated cells in vitro activates the production of chemokines ${ }^{6}$, cytokines ${ }^{6}$, matrix metalloproteinases ${ }^{7.8}$, adhesionmolecules ${ }^{9.10}$ and tissue factor ${ }^{7}$, substances responsible for lesion progression and plaque destabilization.' Administration of antibody against CD154 to low-density lipoprotein receptor-deficient mice has been shown to reduce atherosclerosis and decrease T-lymphocyte and macrophage content; however, only initial lesions were studied. ${ }^{3}$ Here, we determined the effect of genetic disruption of $\mathrm{CD} 154$ in ApoE-/- mice in both initial and advanced atherosclerotic lesions. Plaque area was reduced 5.5 fold. In contrast to previous reports, initial lesion development was not affected. Advanced plaques in CD154-/ApoE-1- mice had a less lipid-containing, collagen-rich, stable plaque phenotype, with a reduced T-lymphocyte/macrophage content. These data indicate that CD40-CD154 signaling is important in late atherosclerotic changes, such as lipid core formation and plaque destabilization.

\section{Methods}

\section{Mice}

CD154-1- mice were generated at Yale University School of Medicine. ApoE-l- mice were obtained from The Jackson Laboratory (Bar Harbor, Maine). Both strains of mice were bred into a C57BL6 background. Mice deficient in both CD154 andApoE were obtained by mating $\mathrm{CD} 154 /$ and $\mathrm{ApOE}-\mathrm{L}$ mice. PCR analysis was used to confirm the absence of both genes.

Primer sequences were: 1) 5'-CCTAGCCGAGGGAGAGCCG-3'; 2) 5'-TGTGACTTGGGAGCTCTGCAGC-3"; and 3) 5'-GCCGCCCCGACTGCATCT-3'. Primers 1 and 2 amplify a 155-base-pair wild-type band; primers 1 and 3 amplify a 245 base-pair mutated band. The male progeny of these matings were used here.

\section{Tissue processing}

Mice were killed at $23 \pm 0.1$ weeks of age (both initial and advanced lesions are resent at this time), after a 24-hour fast. Blood $(0.5-1 \mathrm{ml})$ was obtained from the inferior caval vein to assess lipid profiles. The arterial tree was perfused, through a catheter inserted into the left ventricular apex, for $3 \mathrm{~min}$ with phosphate-buffered

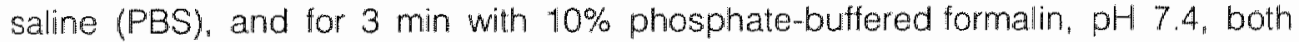
containing $0.1 \mathrm{mg} / \mathrm{ml}$ sodium nitroprusside (Sigma). The aortic arch, including its main branchpoints (brachiocephalic trunk, left common arotid artery and left subclavian artery) as well as the thoracic and abdominal aorta, were removed and fixed in $10 \%$ phosphate-buffered formalin. All vessels were processed and embedded longitudinally in paraffin. The entire aortic arch was then cut into 
approximately 40 sections, and a series of 20 sections $4 \mathrm{um}$ in thickness, which represented the central area of the arch with an intact morphology of the complete arch, was used for analysis. Plasma cholesterol and plasma triglyceride levels were determined in duplicate using colormetric assays (CHOD-PAP 1442341 and GPOPAP701912, respectively: Boehringer).

\section{Histology and morphometry}

For histological analyses, (four sections, $20 \mu \mathrm{m}$ apart) were stained with hematoxylin and eosin (fig. 6.1). Atherosclerotic lesions of both CD154-/-/ApoE-1- and ApoE-1mice were then analyzed and classified as either initial or advanced lesions, based on histological criteria, defined by the American Heart Association. ${ }^{12}$ The number of atherosclerotic plaques, the presence or absence of lipid cores and calcification, and the total number of cells per lesion were also determined. Lawson staining (modified Elastica von Giesson, Verhoef staining), which exclusively stains the elastic laminae, was used to delineate the internal elastic lamina, to permit an easier distinction between media and intima. Four Lawson-stained sections $(20 \mu \mathrm{m}$ apart) were used for morphometrical analysis. All morphometric parameters ere determined using a microscope coupled to a computerized morphometry system (Quantimet 570, Leica, the Netherlands). The aortic arch region was defined as the aortic root to approximately $1.5 \mathrm{~mm}$ caudal from the left subclavian artery branchpoint. Main branchpoints were also included into the measurements: the brachiocephalic trunk, left common carotid artery and left subclavian artery. Plaque area, excluding the underlying media, was determined or each individual plaque. The relative lipid core content was determined by dividing lipid core area by plaque area. The relative fibrous cap thickness was calculated by dividing fibrous cap thickness at the center of the lesion by lesion thickness. The ratio of fibrous cap to lipid core was calculated by dividing fibrous cap thickness by lipid core thickness. both determined at the center of the atherosclerotic lesion. The number of cells per $\mathrm{mm}^{2}$ lesion area was also determined. The relative collagen area (that is, the percentage of area that stained positive for Sirius Red) was determined for each atherosclerotic plaque, using the same morphometry system (fig. 6.2a and b).

\section{immunohistochemistry and morphometry}

Sections were immunolabeled with $\alpha$-smooth muscle actin (ASMA monoclonal antibody, 1:500 dilution; Sigma) as a marker for vascular smooth muscle cells and fibroblasts; ED-1 (1:10 dilution; ref. 20) to detect macrophages; CD3polyclonal antibody (AO452, 1:200 dilution; Dako, Carpenteria, California) to detect T-lymphocytes: and TdT-mediated dUTP nick end labeling (TUNEL) to detect apoptosis (Boehringer) as described. ${ }^{13}$ Lectin staining (GSI-lectin, 1:500 dilution; Sigma) was done to detect neovascularization. To determine the relative amounts of $T$. lymphocytes, macrophages and apoptotic cells in an atherosclerotic plaque, the number of CD3-, ED-1- or TUNEL-positive cells in the entire lesion was divided by the total number of cells in the entire atherosclerotic plaque. To assess the distribution pattern of macrophages, T-lymphocytes and apoptotic cells, labeling indices were also determined at the endothellal coverage, shoulder region, lipid core and fibrous cap. To determine the degree of neovascularization, the number of capillaries positive for lectin was divided by the respective plaque area. The relative 
area of the atherosclerotic plaque positive for a-smooth-muscle actin was determined by dividing the ASMA-positive area by total plaque area, using the morphometry system. All measurements were made by one investigator (E.L.): intraobserver variation was less than $10 \%$.

\section{Statistics}

Data are expressed as mean 2 SEM. CD154/-/ApoE-/-mice were compared with ApoE-t- mice by a non-parametric Mann-Whitney U-test. Data were considered stalistically significant at $p<0.05$.

\section{Results and discussion}

To obtain more insights into the involvement of CD40-CD154 signaling in atherogenesis, we compared initial and advanced lesion development in CD154deficient mice bred on an ApoE-deficient background $(n=12)$ with that in ApoE-1mice $(n=10)$. We used C57BL6 $(n=5)$ and CD154/ $(n=6)$ mice as controls. Mice were killed at $23 \pm 0.1$ weeks of age, as the presence of both initial and advanced lesions has been described in the aortic arch at that time. . $^{11}$

We analyzed 52 atherosclerotic lesions in the aortic arches of CD154/-1 ApoE-1 mice $(n=12)$ and 77 atherosclerotic lesions in the aortic arches of ApoE-1mice $(n=10)$ (figs. 6.1-6.3). There were no lesions in the ApoE $+1+$ control mice. Initial lesions were defined as fatty streaks, containing macrophage-derived foam cells with intracellular lipid accumulation, whereas advanced lesions contained extracellular lipid, a lipid core and/or a fibrous cap. ${ }^{12}$

The total plaque area of the aortic arch was 5.5-fold less in CD154-1-/ApoE-1mice $\left(70,467 \pm 7,788 \mu \mathrm{m}^{2}\right.$ compared with $387,900 \pm 78,077 \mu \mathrm{m}^{2}$ in ApoE-1-) (fig. $6.1 \mathrm{a}$ and b). Furthermore, two aortic arches of CD154/1/ApoE-1-mice showed complete absence of atherosclerotic lesions, whereas lesion development was not absent in any of the ApoE-f-mice. Although the number of both initial lesions per aortic arch $(2.4 \pm 0.72$ compared with $5.6 \pm 1.15$ in ApoE-1-; $p<0.05)$ and advanced lesions per aortic arch $\left(1.38 \pm 0.43\right.$ compared with $2.33 \pm 0.53$ in $\left.A p o E_{-1-;}<<0.05\right)$ were less in CD154-1ApoE-1- mice, individual plaque area was less only in advanced atherosclerotic lesions of CD154-/-/ApoE-1- mice $(\mathrm{p}<0.05)$ (fig. 6.3a). The number of lipid cores per mouse was only 0.6 in CD 154-/ApoE-/- mice, whereas it was 2.0 in ApoE-1- mice $(p<0.05)$. We did not find calcification in any of the atherosclerotic lesions of CD154-1-/ApoE-1- mice, whereas four lesions in ApoE-1-mice had calcified areas.

Further analysis of initial lesions in the aortic arch demonstrated no substantial differences between CD154-1-/ApoE-1-mice and ApoE-/- mice (fig. 6.3a-d), except for a $76.6 \%$ reduction in relative T-lymphocyte content $(p<0.05)$ (fig. $6.3 b)$. To further substantiate the lack of effect of CD154 disruption in lesion initiation, we also analyzed lesions in both the descending thoracic aorta and abdominal aorta. As expected ${ }^{11,13}$, only initial lesions were present in these vessels. As with the results in the aortic arch, there were no differences in initial lesion development between CD154-/-/ApoE-1- and ApoE-/- mice (data not shown). These data show a limited effect of CD154 signaling disruption on initial lesion morphology. 

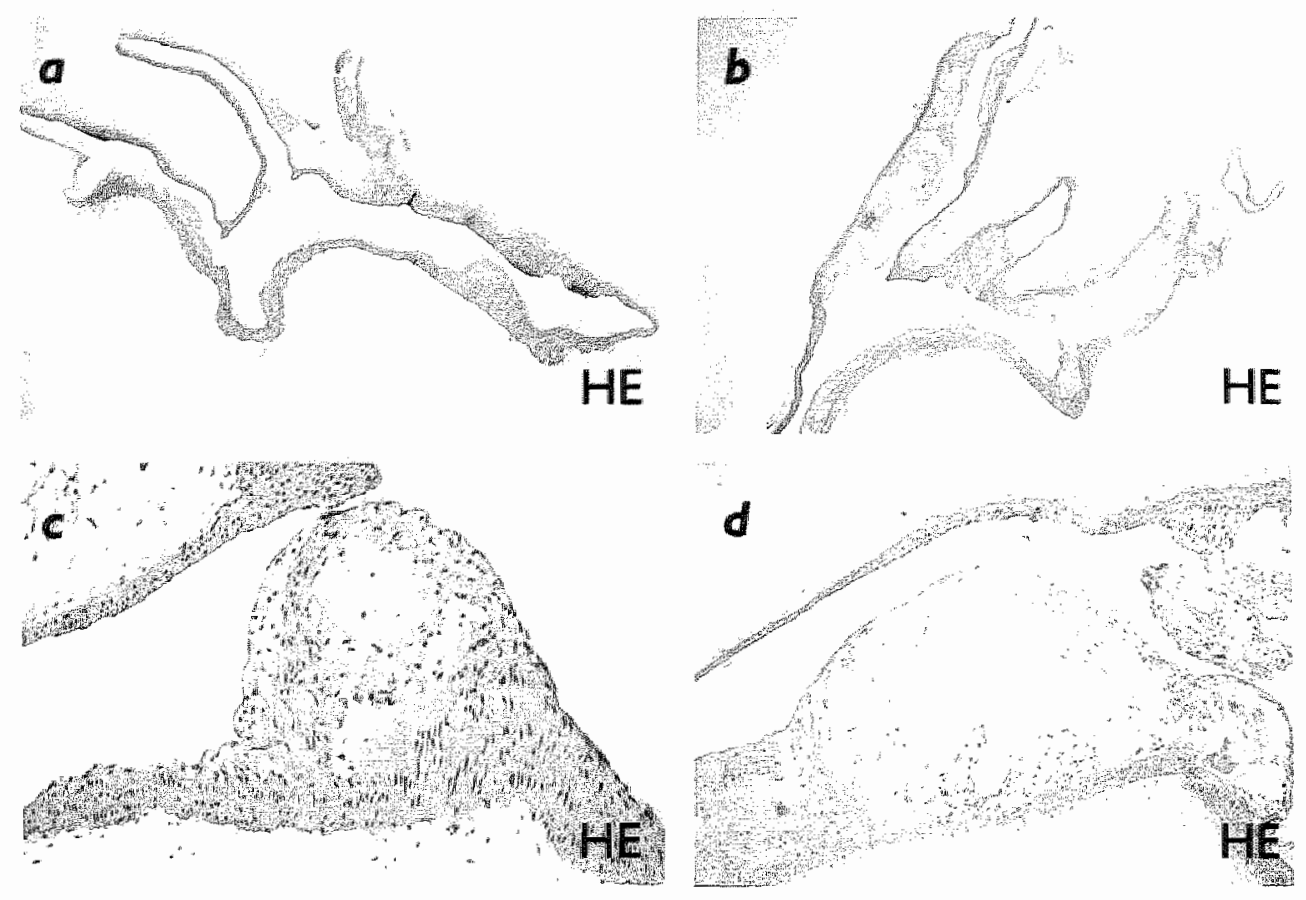

\section{Fig. 6.1}

Atherosclerotic lesions stained with haematoxylin and eosin. $A$ and $C, C D 154-/-/ A p o E-/ w$ mice: $B$ and $D$. ApoE $\ldots$ mice. $A$ and $B$, longitudinal section of the aortic arch, including the brachiocephalic trunk, left carotid artery and left subclavian artery. Both the number of lesions and lesion area are smalier in the CD 154-/-/ApoE-/ mouse (A), than in the ApoE- $/-$ mouse (B). $C$ and $D$. Advanced atheroscleroilc lesion, containing a lipid core and a fibrous cap. The lipid core area is less, and relative tibrous cap thickness is greater in the CD154-/-/ApoE- - - mouse $(C)$, than in the ApoE- mouse (D).

In contrast to the lack of differences in initial lesions, advanced lesions in CD154-1-ApoE-1- mice had several differences compared with advanced atherosclerotic lesions in ApoE-1- mice. Plaques not only were smaller, but also were of a different composition (fig. 6.1c and d). The relative lipid core content in CD154-1-1ApoE- $/$ - mice was $54 \%$ less than that in ApoE- $/$ mice $(p<0.05)$. Relative fibrous cap thickness was 5 -fold more $(p<0.05$ ) (fig. $6.2 a$ and $b$ ). The ratio of fibrous cap to lipid core was $0.23 \pm 0.10$ in ApoE-1- mice and $4.42 \pm 3.21$ in CD154-/ApoE-1- mice $(p<0.05)$. Both relative collagen (figs. 6.2a and $b$ and $6.3 c$ ) as well as the content of vascular smooth muscle cellmyofibroblast (ASMA) were considerably greater (3.4-fold and 5.8-fold, respectively) in CD154-/ApoE-/mice. Advanced atherosclerotic lesions in CD154-/ /ApoE $-1-$ mice contained $50.2 \%$ tewer macrophages and $71.6 \%$ tewer T-lymphocytes than those in ApoE-lmice ( $p<0.05$ ) (figs. $6.2 \mathrm{c}$ and $d$ and $6.3 \mathrm{~b}$ and $\mathrm{d}$ ). In both genotypes, macrophages were distributed throughout the plaque, whereas T-lymphocytes were mainly located 


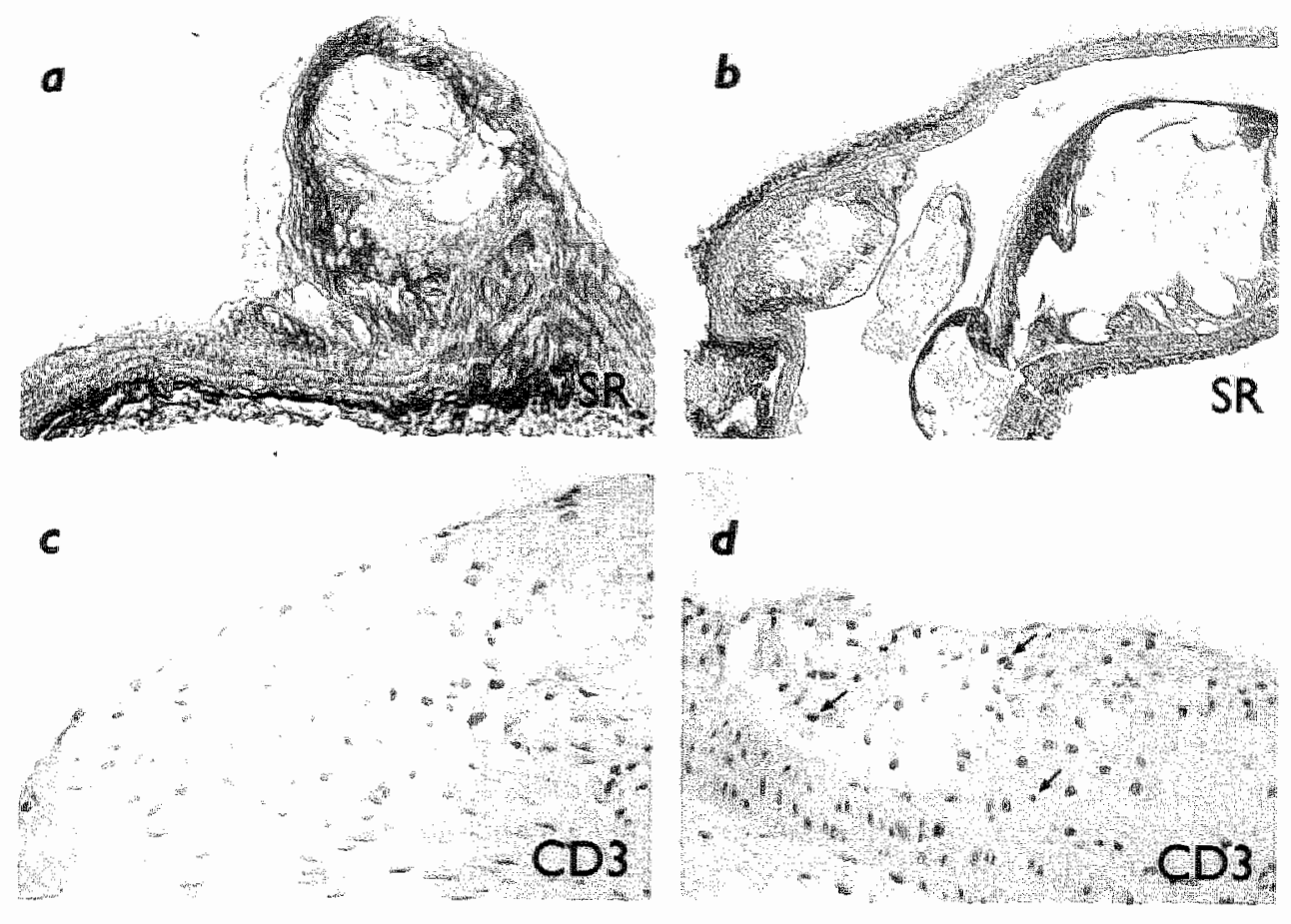

Fig. 6.2

Atherosclerotic lesions stained with Sirius Red and an antibody against CD3. $A$ and $C_{1}$ CD154-/ApoE-/- mice. $B$ and $D$, ApoE-l- mice. $A$ and $B$. Sirius Red staining of the lesions in Fig. $6.1 C$ and $D$, showing a higher relative collagen content in the CD154-/ $/ / A p O E-/-$ mouse $(A)$, than in the ApoE $/$ - mouse $(B), C$ and $D, C D 3$ staining of an advanced atherosclerotic lesion.

in the shoulder region (80.6 $\pm 11.2 \%$ in CD154-/ $/ \mathrm{ApoE}-/-$ and $80.0 \pm 5.5 \%$ in ApoE-l-). Ceil density, as well as the degree of neovascularization, did not differ between ApoE-1- and CD154-/ /ApoE-/- mice $(p>0.05)$. These data show that genetic disruption of CD40-CD154 signaling results in a lipid-poor, collagen-rich. stable lesion morphology in advanced atherosclerotic lesions.

The plasma cholesterol and triglyceride levels of CD154-/ApoE-/- and ApoE-/ mice were higher than those of either CD154- $/$ or C57BI6 mice $(p<0.05)$. However, there were no differences belween CD154-/ /ApoE- / and ApoE-/- mice (cholesterol: $14.18 \pm 1.42 \mathrm{mmol} / \mathrm{l}$ and $13.92 \pm 0.77 \mathrm{mmol} / \mathrm{l}$, $p>0.05$; triglycerides: $3.13 \pm 0.31 \mathrm{mmol} / \mathrm{l}$ and $2.29 \pm 0.21 \mathrm{mmol} / \mathrm{l}, \mathrm{p}>0.05)$.

Thus, our data indicate that CD40-CD154 interactions are essential in the progression from initial to advanced atherosclerotic lesions, but seem to be not required for the initiation of atherosclerosis or lipid metabolism. Furthermore, late atherosclerotic changes, such as macrophage accumulation, lipid core formation and destabilization of the atherosclerotic plaque, all seem to depend on CD40CD154 interactions.

A reduced plaque area as well as a decreased T-lymphocyte and macrophage content has been shown before in atherosclerotic plaques after inhibition of CD40CD154 signaling. However, our study showed a more profound reduction of the progression of atherosclerosis and a completely different plaque phenotype. These 
differences can be explained as follows. The previous study inhibited the CD40CD154 system for only 12 weeks by administering an antibody directed against CD154 (ref. 3), whereas we used mice with a completely disrupted CD154 gene expression. Furthermore, in our study, we used the ApoE-t- mouse as a model of atherosclerosis, whereas the low-density lipoprotein receptor-deficient mouse was used before. The ApoE-1- mouse develops atherosclerosis more aggressively, and advanced atherosclerotic lesions are already present at the age of 15 weeks, even with a normal diet. ${ }^{11}$ In low-density lipoprotein receptor-deficient mice, atherosclerotic lesions progress very slowly and advanced fibrofatty lesions are not seen until 8.5 months of high-cholesterol feeding. ${ }^{14}$ The previous study ${ }^{3}$ was concentrated on the effects of inhibition of the CD40-CD154 system in low-density lipoprotein receptor-deficient mice after 12 weeks of high-cholesterol feeding, so it focused on initial atherosclerotic lesions only. In contrast, we specifically sought to determine the effects of complete inhibition of the CD4O-CD154 system on both initial and advanced lesions of ApoE-1- mice, and we found the most prominent effect on advanced lesion progression and composition.

Both CD40 and CD154 are present on several cell types, including activated Tlymphocytes, macrophages, vascular smooth muscle cells and endothelial cells in the atherosclerotic plaque in vivo. ${ }^{3.8}$ Stimulation of the CD40-CD154 pathway in these cell types in vitro results in the activation of different proatherogenic pathways. ${ }^{6,8}$ The absence of CD154 may inhibit several of these pathways.

As CD154 is present on T-lymphocytes, but only when they are activated ${ }^{3}$, and as CD154 is required for T-cell priming ${ }^{15}$, and intimal T- lymphocytes are activated', it is likely that T-lymphocytes in CD154-/ApoE-1- mice are not activated and are not able to activate pro-atherogenic pathways, which, as our data indicate is more important for lesion progression than for lesion initiation. Activated T-lymphocytes can induce the expression of several cytokines important in lesion progression and plaque destabilization. "However, in double-knockout studies, the effects of interventions in the immune system are heterogenic. Like the lesions in CD154-1-/ApoE- - - mice, the atherosclerotic lesions in ApoE- - -linterferon- $\gamma$ deficient mice have a collagen-rich, lipid-poor stable plaque phenotype ${ }^{16}$, whereas ApoE-1mice delicient in both T-lymphocytes and B-lymphocytes have a reduced plaque area of initial atherosclerotic lesions, but fail to show a plaque phenotype different from that of normal ApoE $-/-$ mice. ${ }^{17}$

The reported distribution of CD154 in the plaque ${ }^{3,8}$, the heterogeneous outcome of several interventions in the immune system ${ }^{16.17}$ and the results of our study indicate involvernent of the CD40-CD154 pathway in atherosclerosis between cell lypes other than T-lymphocytes and B-lymphocytes. Another cell type considered important during atherogenesis is the macrophage. ${ }^{1}$ Plaque macrophages either induce the expression of or are activated by most of the proatherogenic chemokines, cytokines, adhesion molecules and proteolytic enzymes in atherosclerotic plaques. Furthermore, macrophages can express tissue factor and are able to oxidize lipids, all factors essential for lesion formation and progression. Substantial evidence indicates CD40-CD154 interactions are important in these processes. ${ }^{2.3 .9,18}$ Therefore, inhibition of T-lymphocyte and macrophage functions 
A Plaque Area

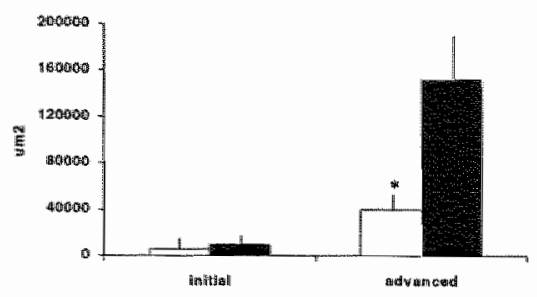

c

Collagen content

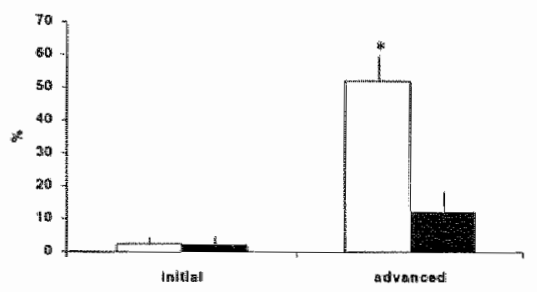

B

\section{T-lymphocyte contient}

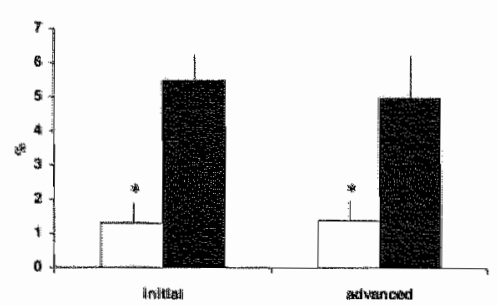

$\mathbb{D}$

Macrophage content

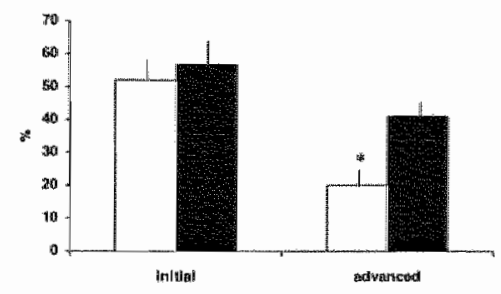

Fig. 6.3

Quantification of plaque characteristics of CD154\%/ApoE- $/$ and ApoE- mice. $A_{1}$ individual plaque area. B. T-lymphocyte content, C. collagen conient, and D, macrophage content were measured in initial and advanced lesions of CD154-//ApoE- $/$ mice (white), and ApoE-/- mice (black).

dependent on CD40-CD154 interactions might cause the different plaque phemotype in CD154-1/ApoE-1- mice.

The different, more stable plaque phenotype in CD154-/ApoE-1- mice emphasizes the importance of this pathway in plaque destabilization. Our study has shown that complete absence of CD154 during atherogenesis resulted in an increased extracellular matrix component (possibly by a decreased degradation by matrix metalioproteinases ${ }^{7}$ ), increased fibrous cap thickness, a decreased content of inflammatory cells and a decreased lipid core content "all factors that are favorable for plaque stability. Another important factor inducing plaque instability is apoptosis in the lipid core and fibrous cap. ${ }^{13,19}$ Alhough the degree of apoplosis was not different for ApoE- $/$ and CD154-1/ApoE-m-mice (initial lesions, $0.7 \pm 0.7 \%$ and $0.8 \pm 0.6 \%$; advanced lesions, $1.1 \pm 0.2 \%$ and $1.2 \pm 0.3 \%$, the distribution pattern differed. In CD154-1-/ApoE-1- mice, apoptotic cells were distributed throughout the plaque, whereas in ApoE-1- mice, apoptosis was confined mostly to the center of 
the plaque $162.8 \%$ in ApoE-1- mice compared with $19.7 \%$ of all apoptotic cells in CD154-1ApoE-1-1-mice; p<0.05), which may make lesions of CD154/-/ApoE-1mice less rupture-prone.

Thus, interuption of CD40 signaling may provide a therapeutical target in atherogenesis. Antibodies directed against CD154 or CD40 might not prevent the initiation of atherosclerosis, but may be beneficial in inhibiting lesion progression and in increasing the stability of the atherosclerotic plaque, thereby decreasing the acute manfestations of atherosclerosis.

\section{Acknawledgments}

We thank $C$. Hughes for the original generation of the CD154 knockout mice. Part of this research was sponsored by the Wynand Pon Foundation. Leusden, the Netherlands. R.A.F. is an investigator and L.G. is an Associate of the Howard Hughes Medical Insitute. I.S.G. was supported by a Juvenile diabetes Fellowship.

\section{References}

1. Ross R. Atherosolerosis. An inflammatory disease. N Engl J Med 1999; 340:115-126.

2. Mach F, Schönbeck U. Libby P. CD40 signaling in vascular cells: A key role in atherosclerosis? Atherosclerosis 1998; 137:589-595.

3. Mach F. Schönbeck U. Sukhova GK. Atkinson E, Libby P. Reduction of atherosclerosis in mice by inhibition of CD40 signaling. Nature 1998;394:200-203.

4. Grewal IS, Flavell RA. A central role of CD40 ligand in the regulation of CD4+T-cell responses. immunol Today 1996; 17:410-414.

5. Arulfo A, Farrington M, Hollenbaugh D, Li X. Milatovich A, Nonoyama S, Barojath J, Grosmaire LS. Stenkamp R. Neubauer M, Roberts RL, Noelle RJ, Ledbetter JA. Francke U. Ochs HD. The CD4O ligand, gp39, is defective in activated T cells from patients with $X$-inked hyper-/gM syndrome. Cell $1993 ; 72: 291-300$

6. Mach F. Schönbeck U, Bonneroy JY, Pober JS, Libby P. Functional CD40 ligand is expressed on human vascular endothelial cills, smooth muscle cells, and macrophages: Implications for CD40-CD4OL signaling in atherosclerosis. Proc Nall Acad Sci U S A 1997:94:1931-1936.

7. Mach F, Schonbeck U. Bonneloy JY, Pober JS, Libby P. Activation of monocyte/macrophage functions related to acute aheroma complication by ligation of CD40. Induction of collagenase. siromelysin, and tissue factor. Circulation 1997:96:396-399.

8. Schöbeck U, Mach F. Sukhowa GK, Murphy C, Bonnefoy JY. Fabunmi RP, Libby P. Regulation of matrix metalloproteinase expression in human vascular smooth muscle cells by $T$ lymphocytes. A role for CD40 signaling in plaque rupture? Circ Res 1997;81:448-454.

9. Kornbluth R, Kee K, Richman DD. CD40 ligand (CD154) stimulation of macrophages lo produce HIV-1-suppressive-chemokines. Proc Natl Acad Sci U S A 1998:95:5205-5210.

10. Yellin MJ, Brett J, Baum D. Matsushima A, Szabolcs M. Stern D. Chess L. Funchional interactions of $T$ cells with endothelial cells: The role of CD4OL-CD40mediated signals. J Exp Med 1995:182:1857-1864.

11. Nakashima Y. Plump AS, Raines EW, Breslow Jll. Ross R. ApoE-delicient mice develop lesions of all phases of atherosclerosis throughout the arterial tree. Arterioscler Thromb Vasc Biol $1998: 14: 133-140$.

12. Stary HC, Chandler AB, Dinsmore RE. Fuster $V$. Glagow $S$, Insull W Jr, Rosenfeld ME. Schwartz Cu. Wagner WD, Wissler RW. A definition of advanced iypes of atherosclerotic lesions and a histological classification of atherosclerosis. A report from the Committee on Vascular Lesions of 
the Councll on Arteriosclerosis, American Heart Association. Arterioscler Thromb Vasc Biol $1995 ; 15: 1512-1531$.

13. Lutgens E, Daemen M, Kockx M. Doevendans P. Hotker M. Havekes L. Wellens H, de Muinck E. Atherosclerosis in APOE*3 Leiden transgenic mice: from proliferative to atheromatous stage. Circulation 1999:99:276-283.

14. Johnson RC, Chapman SM. Dong ZM. Ordovas JM, Mayadas TN. Herz J. Hynes RO. Schaeter EJ. Wagner DD. Absence of P-selectin delays latty streak formation in mice. J Clin muest $1997.99: 1037-1043$.

15. Grewal IS, Xu J. Flavell RA. Impairment of antigen-specific T-cell priming in mice lacking CD4O ligand. Nature 1995;378:617-620.

16. Gupta S, Pablo AM, Jiang XC, Wang $N$, Tall $A R$, Schindier $C$. IFN $\gamma$ potentiates atherosclerosis in ApoE knock-oult mice. J Clin Inwest 1997:99:2752-2761.

17. Dansky HM. Charlton SA. Harper M. Smith JD. T- and B-lymphocytes play a minor pole in atherosclerotic plaque formation in the apolipoprotein E-deficient mouse. Proc Natl Acad Soi US A 1997:94:4642-4646.

18. Terkeltaub $R$, Boisvert WA, Curtiss LK. Chemokines and atherosclerosis. Curr Opin Lipidol 1998;9:397-405

19. Lutgens E, de Muluinck E, Kitslaar PJEHM, Tordoir JHM, Wellens HJJ, Daemen MUAP. Biphasic pattern of cell iumover characterizes the progression from fatty streaks to ruptured human atherosclerotic plaques. Cardiovasc Res 1999:41:473-479.

20. Dijkstra CD. Dopp EA, Joling P. Kraal G. The heterogeneity of mononuclear phagocytes in lymphoid organs: distinct macrophage subpopulations in the rat recognized by monoclonal antibodies ED1, ED2 and ED3. Immunology 1985 54: 589-599. 


\section{Chapter 7}

Both early and delayed anti-CD40L antibody treatment induces a stable plaque phenotype

Esther Lutgens, Kitty Cleutjens, Sylvia Heeneman, Victor Koteliansky. Linda Burkly and Mat Daemen

Proc Nat Acad SciU S A 2000;97:7464-7469

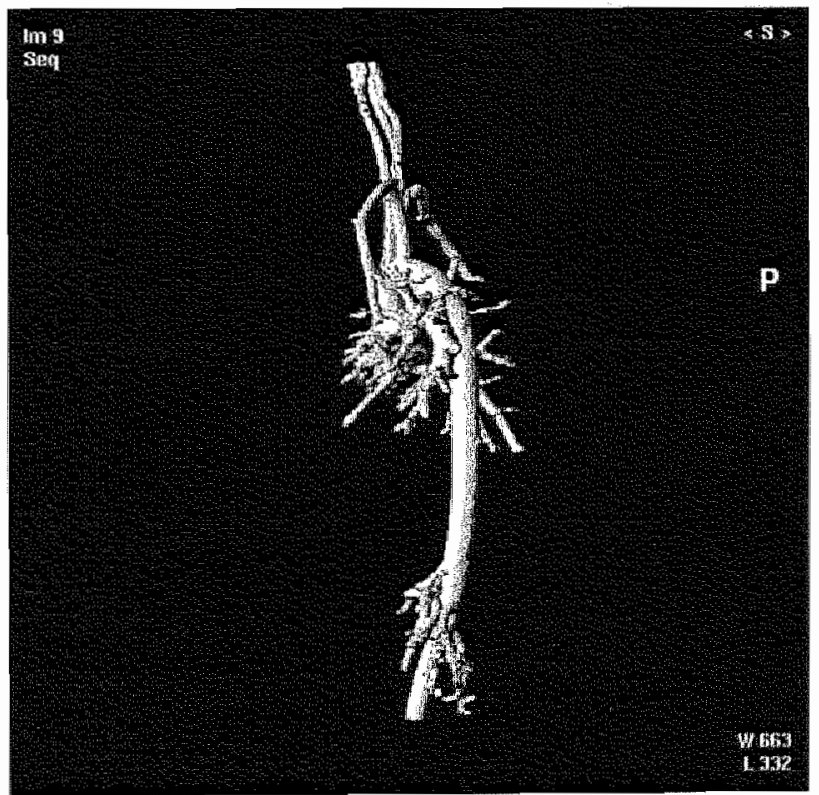




\section{Abstract}

In the present study, we investigated the role of the CD4OL-CD40 pathway in a model of progressive atherosclerosis. ApoE-f- mice were treated with an antiCD4OL antibody or a control antibody for 12 wks. Antibody treatment started early (age 5 wks) or was delayed until the establishment of atherosclerosis (age $17 \mathrm{wks}$ ). In both the early and delayed treatment groups, anti-CD4OL antibody did not decrease plaque area or inhibit lesion initiation or age-related increase in lesion area. The morphology of initial lesions was not affected, except for a decrease in TIymphocyte content. Effects of anti-CD40L antibody treatment on the morphology of advanced lesions were pronounced. In both the early and delayed treatment groups, T-lymphocyte content was significantly decreased. Furthermore, a pronounced increase in collagen content, vascular smooth muscle cell/myofibroblast content, and fibrous cap thickness was observed. In the delayed treatment group, a decrease in lipid core and macrophage content occurred. Interestingly, advanced lesions of anti-CD40L antibody-treated mice exhibited an increased transforming growth factor $\beta_{1}$ immunoreactivity, especially in macrophages.

In conclusion, both early and delayed treatment with an anti-CD4OL antibody do not affect atherosclerotic lesion initiation but do result in the development of a lipidpoor collagen-rich stable plaque phenotype. Furthermore, delayed treatment with anti-CD40L antibody can transform the lesion profile from a lipid-rich to a lipid-poor. collagen-rich phenotype. Postulated mechanisms of this effect on plaque phenotype are the down-regulation of pro-inflammatory pathways andupregulation of collagenpromoting factors like transforming growth factor $\beta$. 


\section{Introduction}

Increasing evidence suggests a central role for the CD4OL-CD40 signaling pathway in several immunogenic and inflammatory processes, including atherosclerosis. The interaction between CD4OL (CD154, gp39) and CD40, members of the tumor necrosis factor (TNF) and TNF-receptor family, respectively, was originally thought to be restricted to $T$ - and B-lymphocytes. ${ }^{1}$ However, this interaction is now found to play an important role in several autoimmune diseases, including the $X$-linked hyperlgM syndrome ${ }^{2}$, collagen-induced arthritis ${ }^{3}$, allergic encephalitis and multiple sclerosis ${ }^{4}$, and acute and chronic graft versus host disease. ${ }^{5,6}$

An important role for CD4OL-CD40 signaling in atherosclerosis has been reported. ${ }^{7-9}$ In atherosclerotic plaques of mice and humans, CD $40 \mathrm{~L}$ and CD 40 are present on vascular smooth muscle cells (NSMCs), endothelial cells, macrophages, and T lymphocytes. ${ }^{8.9}$ In vitro stimulation of CD4OL-CD40 signaling in atheromaderived cells ${ }^{10}$ results in the activation of proatherogenic pathways, like the production of chemokines ${ }^{10}$, cytokines ${ }^{10}$, matrix metalloproteinases ${ }^{9.11}$, tissue factor ${ }^{11}$, and leukocyte adhesion molecules. ${ }^{12-14}$

Recently, we reported an important role for CD4OL-CD40 interactions in the progression of atherosclerosis by using mice deficient in CD4OL and apoE. We showed a dramatic decrease in plaque area in CD40L-1-lapoE-1- mice compared with control apoE-deficient animals. Moreover, advanced atherosclerotic lesions of these mice showed a lipid-poor collagen-rich stable plaque phenotype, with reduced macrophage and T-lymphocyte content. ${ }^{7}$ Furthermore, administration of an anti-CD4OL antibody to LDL-R-/- mice, when started early in the development of atherosclerosis, inhibited lesion initiation. ${ }^{8}$

In this study, we investigated further the role of the CD40L-CD40 pathway in atherosclerotic piaque development and progression. An anti-CD4OL antibody was administered to apoE- $/$ - mice for 12 wks, either at the onset of atherosclerosis (early treatment) or after the development of advanced plaques (delayed treatment). AntiCD4OL antibody treatment affected neither plaque area nor the age-related increase in plaque area. The most prominent effect of anti-CD $40 \mathrm{OL}$ antibody treatment in both treatment groups was the development of a lipid-poor, collagen-rich stable plaque phenotype, a phenotype similar to that in CD4OL-/-/apoE-/- mice. ${ }^{7}$

Because most acute complications of atherosclerosis, like myocardial infarction and cerebrovascular accidents, are the result of a rupture of an unstable lipid-rich, collagen-poor lesion ${ }^{15}$, anti-CD4OL antibody treatment may prevent the acute complications of advanced atherosclerosis.

\section{Methods}

\section{Mice}

ApoE-1- mice (Iffa Credo), on a normal chow diet, received either a hamster anti$\mathrm{CD} 40 \mathrm{~L}$ antibody or a hamster conirol lgG, generously provided by Biogen Inc. (Cambridge,MA, USA), at $500 \mu \mathrm{g}$ per mouse by i.p. injection once per week for 12 wks. The early treatment group started at 5 wk of age ( $n=9$ anti-CD $40 \mathrm{~L}, n=8$ control), when hardly any atherosclerotic lesions were present. The delayed treatment group 
( $n=8$ anti-CD40L, $n=9$ control) started at 17 wks of age, the time point at which advanced atherosclerotic plaques have developed.

\section{Lipid Profile}

Plasma cholesterol and plasma triglyceride levels were determined in duplicate by using colorimetric assays (CHOD-PAP 1442341 and GPO.PAP 701912. respectively; Boehringer Maninheim).

\section{Histomorphometry}

Atherosclerollic plaques were divided into initial and advanced lesions. Initial lesions were defined as fatty streaks containing macrophage-derived foam cells with intracellular lipid accumulation (AHA type II) or pools of extracellular lipid (AHA type 111), whereas advanced lesions contained extracellular lipid, a lipid core (AHA type IV), and/or a fibrous cap (AHA type $\mathrm{Va-C}$ ). ${ }^{16}$ Tissue processing, histological classification, and morphometry were performed as described previously."17

\section{Immunohistochemistry}

Sections were immunolabeled with $\alpha$-smooth muscle actin ((ASMA) $)^{\text {FIC }}$ monoclonal. 1:3,000; Sigma) as a marker for vascular smooth muscle cells and fibroblasts, ED. $1^{20}(1: 10)$ for the detection of macrophages, CD3 (CD3 polyclonal, 1:200; Dako $\mathrm{A0452)}$ for the detection of $T$ Iymphocytes, anti-transforming growth factor $\beta 1$ (Bionostics. Wyboston, Bedfordshire, U.K.) for the detection of transforming growth factor (TGF)B1, BrdUrd (Mas 250b, Harlan Laboratories, Haslett, MI) for the detection of DNA-synthesizing cells, and terminal deoxynucleotidyltransferasemediated UTP end labeling (Boehringer Mannheim) for the detection of apoptosis, as described previously. 7,17

\section{Statistical Analysis}

Data are expressed as meantSEM. Anti-CD40L antibody-treated apoE-1- mice were compared with control-treated apoE-1- mice. Anti-CD4OL antibody-treated apoE-F- mice of the delayed treatment group were also compared with controltreated 17 -wk-old apoE-1-mice to investigate plaque progression after treatment. For all analyses, a nonparametric Mann-Whitney $U$ test was used. The level of statistical significance was set at p<0.05.

\section{Results}

\section{General}

No significant differences in age, body weight, cholesterol, or triglyceride levels were observed between anti-CD4OL antibody- and control-treated animals. Macroscopic and histological analysis of lungs, liver, intestine, spleen, and kidneys revealed no pathology in either anti-CD40L antibody-or control-treated mice. One mouse of the early anti-CD $40 \mathrm{~L}$ antibody treatment group and one mouse of the delayed treatment group died during the experiment. 


\section{Early Treatment}

In total, 57 atherosclerotic lesions in the aortic arch of the anti-CD4OL antibodytreated $(n=8)$ and 49 lesions of control-treated animals $(n=8)$ were analyzed. Total plaque area $\left(24,625 \pm 11,290 \mu \mathrm{m}^{2}\right.$ per aortic arch, anti-CD $40 \mathrm{~L}$ vs. $32,485 \pm 15,061 \mu^{2}$ per aortic arch, control) and individual initial and advanced plaque area did not differ between the treatment groups (fig. 7.1a). Furthermore, no differences between the treatment groups could be observed in the number of initial ( $4.6 \pm 0.7$ anti-CD $40 \mathrm{~L}$ and $4.0 \pm 0.8$ control) or advanced ( $2.5 \pm 0.5 \mathrm{vs}, 2.4 \pm 0.7$ ) plaques, or in the number of lipid cores $(0.8 \pm 0.4$ vs. $0.9 \pm 0.3)$ or chondrocyte-containing plaques $(0.4 \pm 0.1$ vs. $0.3 \pm 0.1)$ per aortic arch.

\section{Initial Lesions}

Detailed histomorphological analysis revealed that no parameters except $\mathrm{T}$ lymphocyte content differed between anti-CD40L antibody and contro-treated groups. The relative T-lymphocyte content was $0.4 \pm 0.2 \%$ in the anti-CD $40 \mathrm{~L}$ antibody-treated group, whereas it was $4.4 \pm 1.3 \%$ in the control-treated group $(p<0.05)$ (fig. 7.1b). Relative macrophage content and collagen content, as well as ASMA content, did not differ between the treatment groups (fig. $7.1 \mathrm{C}-\mathrm{f}$ ). Also, no differences in cell number $\left(7,941 \pm 1,416 \mu \mathrm{m}^{2}\right.$ in anti-CD $40 \mathrm{~L}$ vs. $5,718 \pm 1,016 \mu \mathrm{m}^{2}$ in control), DNA synthesis $(3.7 \pm 1.6 \%$ vs. $13.6 \pm 5.8 \%)$, or apoptosis $(0.3 \pm 0.2 \%$ vs. $0.4 \pm 0.3 \%)$ could be observed $(p<0.05)$. The ratio between type II and type III lesions did not differ between both treatment groups (6. $4 \pm 2.4$ vs. $3.6 \pm 1.8)(p<0.05)$.

To substantiate further the lack of effect of early treatment on lesion initiation, lesions of descending thoracic and abdominal aorta were also analyzed. As expected, only small initial lesions were present. No differences in initial lesion development were found between the treatment groups.

\section{Advanced Lesions}

In contrast to initial lesions, analysis of advanced atherosclerotic lesions revealed several differences in plaque composition between the treatment groups. First of all, a $48 \%$ reduction in $T$-lymphocytes was observed in the anti-CD4OL antibody-treated mice $(p<0.05)$ (fig. $7.1 b)$. Furthermore anti-CD40L antibody treatment resulted in an $81.2 \%$ increase in collagen content and a $325 \%$ increase in ASMA content $(p<0.05)$ (fig. 7.1e and f). Thus, fibrous caps were significantly thicker in anti-CD4OL-treated animals ( $37.9 \pm 7.2$ vs. $15.2 \pm 0.6 \mu \mathrm{m})(p<0.05)$. No differences could be observed in macrophage content, lipid core content (fig. 7.1c and d), and chondrocyte content. Also, total cell number $\left(4,16 \pm 485\right.$ vs. $\left.5,886 \pm 2,632 \mu \mathrm{m}^{2}\right)$, as well as the fraction of DNA-synthesizing (2.9 $\pm 1.2 \%$ vs. $3.2 \pm 0.9 \%)$ or apoptotic $(1.2 \pm 0.3 \%$ vs. $3.2 \pm 0.9 \%)$ cells did not differ.

The ratio between type IV and $V$ lesions did not differ between anti-CD4OL antibody - and control-ureated mice ( $1 \pm 0.3$ vs. $1 \pm 0.5)(p<0.05)$. However, subdivision of type $V$ lesions into either type Va (lipid rich) and type Vo (fibrous), revealed that in the anti-CD 40L antibody-treated group, 50\% of type $V$ lesions were confined to type $V_{c}$ (fibrous), whereas in the control-treated group. most of type $V$ lesions were type Va (lipid-core rich) $(87.5 \%)(p<0.05)$. 


\section{Plaque area}

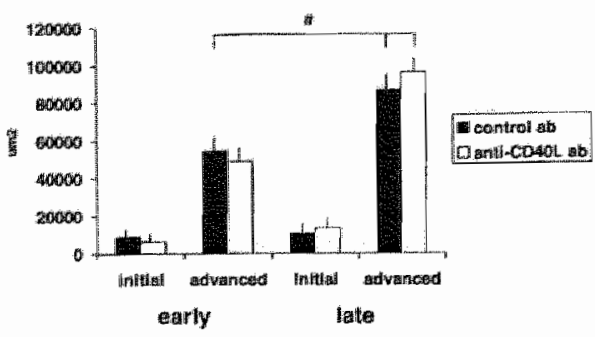

C:

$\theta$ b
Macrophage content
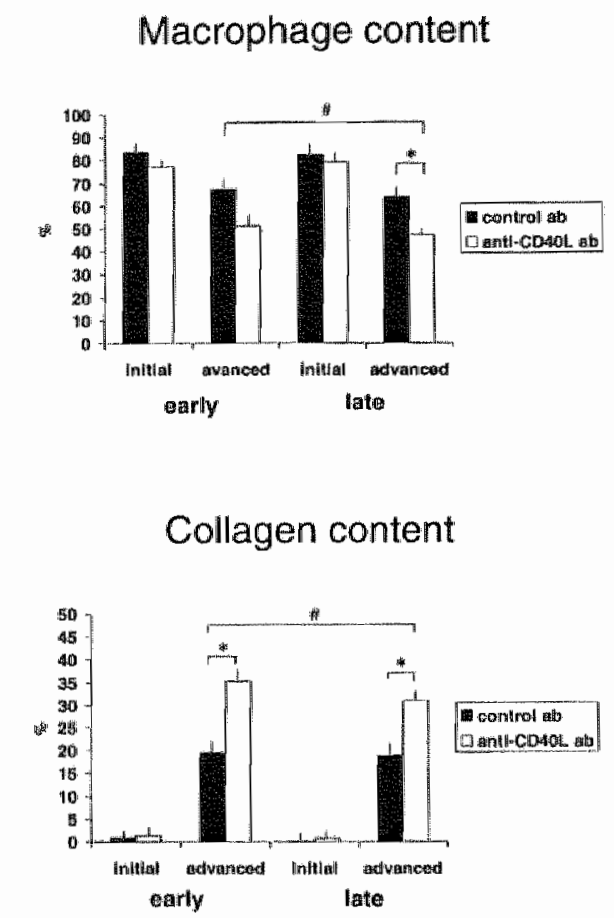

\section{T-Lymphocyte content}

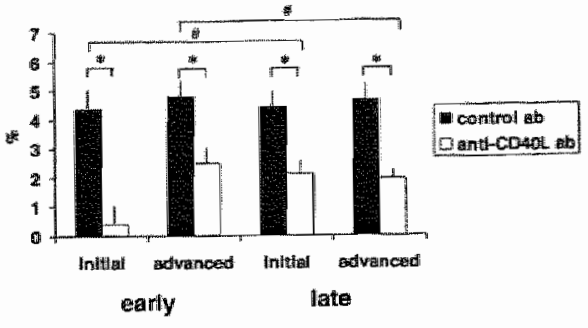

$d$

\section{Lipid core content}

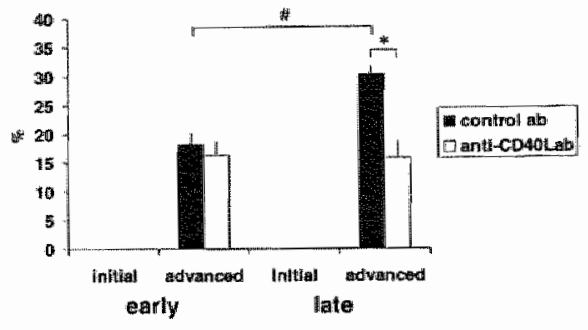

f
ASMA content

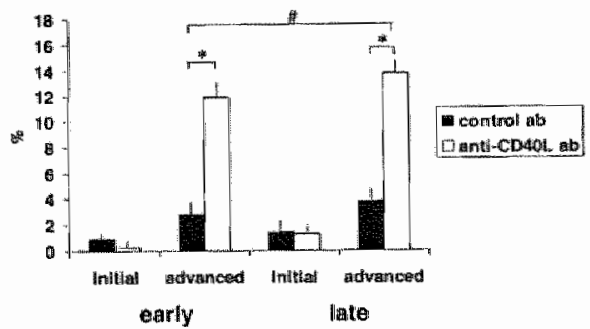

Fig. 7.1

Quantification of plaque characteristics of both early and delayed anti-CO4OL antibody-and control. treated apoE-f mice. A, Individual plaque area, $B$. T-ymphocyte content; $C$ macrophage content; $D$, lipid core content; $E$, collagen content: F. ASMA content. " $P<0.05$, anti-CD 4OL antibody vs. control; $p<0.05$, 17 wk conirol treatment group (age at which delayed treatment started) vs delayed antiCD4OL antibody treatment group or delayed control treatment group. 


\section{Delayed Treatment}

Seventy-six atherosclerotic lesions of the anti-CD40L antbody-lreated group (n=8 mice) and 87 lesions of the control-treated group $(n=8)$ were analyzed. Concordant with the results of the early treatment group, no differences could be observed in total plaque area $\left(430,947 \pm 64,377 \mu \mathrm{m}^{2}\right.$ vs. $\left.414,133 \pm 64,158 \mu \mathrm{m}^{2}\right)$ (fig. $7.2 \mathrm{a}$ and b), individual initial or advanced plaque area (fig. 7.1a), the number of either initial (5.0t0.5 vs. $6.0 \pm 0.5$ per aortic arch) or advanced ( $4.3 \pm 0.7 \mathrm{vs} .4 .6 \pm 0.7$ per aortic arch) plaques, and the number of chondrocyte-containing lesions $(0.3+0.3 \mathrm{vs}$. $0.6 \pm 0.4)$ between anti-CD40L antibody- and control-antibody $(p<0.05)$. However, delayed treatment with anti-CD40L antibody decreased the number of lipid cores $(2.7 \pm 0.7$ vs. $3.9 \pm 0.5$ per aortic arch $)(p<0.05)$.

\section{Intitial Lesions}

As in the early treatment group, detailed histo-morphological analysis showed a reduction (67\%) in T-lymphocyte content after anti-CD40L antibody treatment (p<0.05) (fig. 7.1b). Macrophage content (fig. 7.1c), collagen content (fig. 7.1e), total cell number $\left(4,355 \pm 677\right.$ vs. $\left.4,337 \pm 872 \mu \mathrm{m}^{2}\right)$. DNA synthesis $(4.5 \pm 1.8 \%$ vs. $5.2 \pm 1.2)$, apoptosis $(0.1 \pm 0.1$ vs. $0.5 \pm 0.2)$, and the ratio between ype $I 1$ and III lesions were not affected (7.8 1.0 vs. 2.6 10.9$)$ after anti-CD40L antibody treatment $(p<0.05)$.

\section{Advanced Lesions}

As in advanced lesions of the early treatment group, lesions of the anti-CD4OL. antibody-treated mice of the delayed treatment group also exhibited a decrease in T-lymphocyte content (58\%), and increases in collagen content (64.2\%), ASMA content ( $269.2 \%)$, and fibrous cap thickness $(54.4 \%)$ were observed $(p<0.05)$ (fig. $7.1 \mathrm{~b}-\mathrm{f}$, fig. $7.2 \mathrm{c}-\mathrm{h})$. However, in the delayed treatment group, changes in plaque phenotype were more pronounced. Macrophage and lipid core content had decreased significantly compared with the control treated animals ( $26 \%$ and $48 \%$ ) ( $p<0.05$ ) (fig. 7. $1 \mathrm{c}-\mathrm{d}$, fig. 7.2c, d, i, and j). Also, the chondrocyle positive area of chondrocyte containing lesions was significantly enlarged (19.4t4.6\% in anti-CD4OL vs. $6.8 .61 .2 \%$ in control) ( $P<0.05$ ). The ratio between type $I V$ and type $V$ lesions did not differ between both treatment groups $0.4 \pm 0.2$ in anti-CD $40 \mathrm{~L}$ antibody $v \mathrm{~s}$. $0.9 \pm 0.4$ in control) $(p<0.05)$. However, in anti-CD40L antibody treated animals, $79.2 \%$ type Vlesions were type Vc (fibrous), compared with $20.8 \%$ in control-treated animals.

\section{Plaque Progression}

To investigate the effects of delayed anti-CD4OL antibody treatment on plaque progression, we also compared the delayed anti-CD4OL antibody treatment group (age $29 \mathrm{wk}$ ) with the 17 -wk-old control-treated group (the age at which delayed antibody treatment started). This revealed that anti-CD4OL antibody treatment did not prevent the age-related increase in placue area (fig. $7.1 \mathrm{a}$ ) or the increase in the number of initial $(4.0 \pm 0.8$ to $6.0 \pm 0.5)$ or advanced $(2.4 \pm 0.8$ to $4.6 \pm 0.7)$ plaques $(p<0.05)$. However, several phenotypical changes occur with anti-CD $40 \mathrm{~L}$ antibody treatment. The percentages of T-lymphocytes decreased in both initial $(56 \%)$ and 

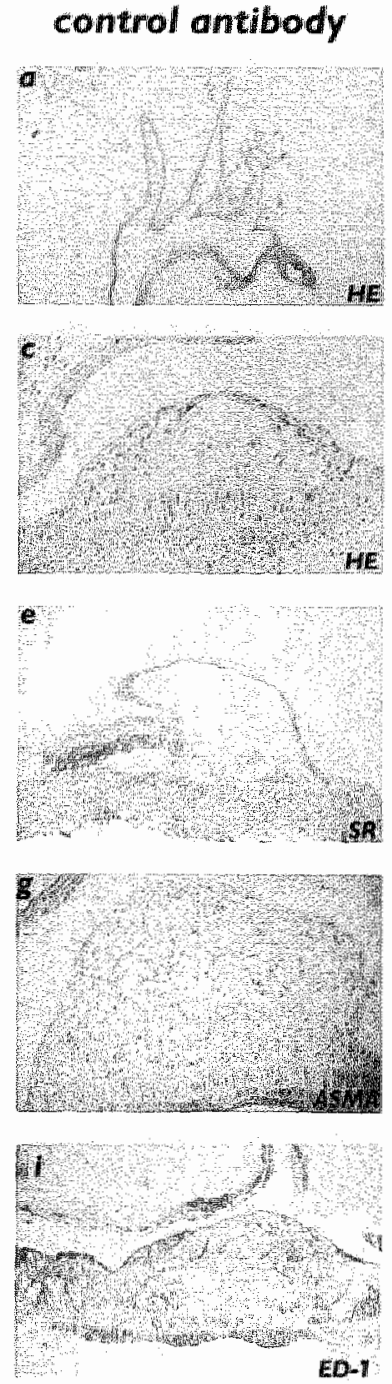

\section{anti-CD40L antibody}
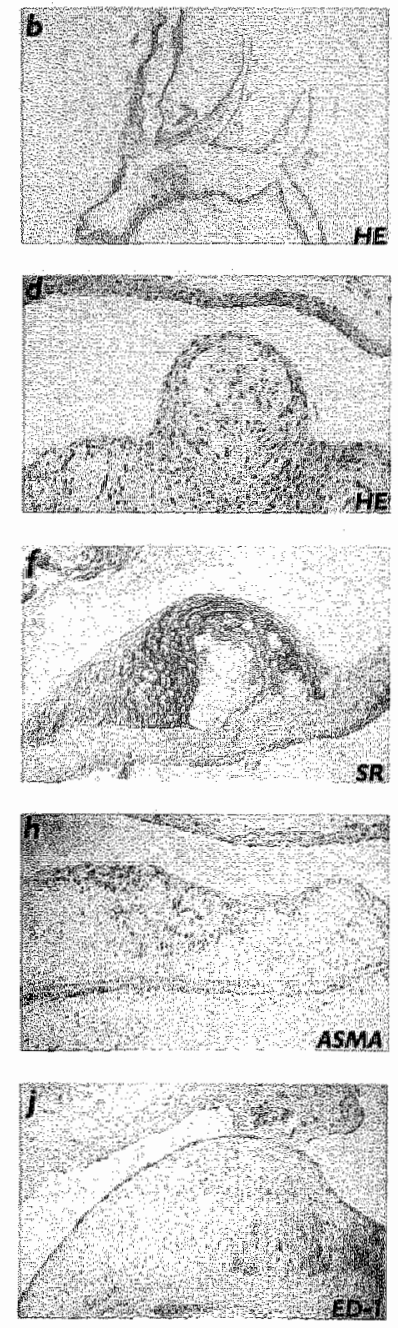

Fig. 7.2

Histological characteristics of delayed anti-CD4OL antibody treatment. (A and $B$ ) Hematoxylin and eosin-stained longitudinal section of the aortic arch, including the brachiocephalic trunk, left carotid. and left subclavian artery ( $\left.{ }^{*} 25\right)$. Neither lesion area nor the number of lesions differed between antiCD4OL antibody-and control-treated mice. (C and D) Advanced atherosclerotic lesion, containing a

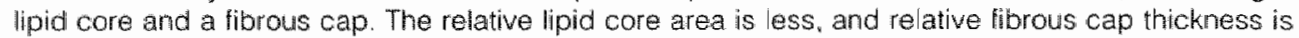
increased in anti-CD4OL antibody (D) compared to control-treated mice $(D)$. ( $E$ and $A$ Sirius red staining of advanced atherosclerotic lesions, showing a higher relative collagen content in the antiCD4OL antibody-treated mouse ( $F$ ) than in the control-treated mouse ( $E$ ). (G and $H$ ) ASMA staining of advanced atherosclerotic lesions, showing a higher relative VSMC/myofibroblast content in the antiw CD4OL-treated mouse $(H)$ than in the control-treated mouse $(G)$. (I and $J) E D$ - 1 staining of advanced atherosclerotic lesions, showing a decreased relative macrophage content in the anti-CD4OL-treated mouse (n) compared to the control-treated mouse (n). 

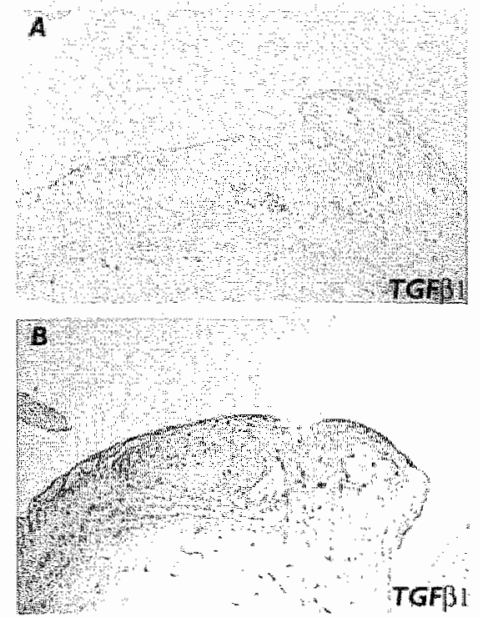

Fig. 7.3

Anti-CD4OL antibooly treatment induces increased immunoreactivity of TGF $\beta$ 1. ( $A$ and $B$ ) TGF $B 1$ immunostaining of advanced atherosclerotic lesions, showing an increased immunoreactivity of TGF $\beta$ in macrophages of the anti-CD4OL antibody-treated mouse $(B)$ compared with the control-treated mouse (A).

advanced lesions $(59 \%)(p<0.05)$ (fig. $7.1 \mathrm{~b})$, as did the macrophage content $(30 \%)$ $(p<0.05$ ) (fig. $7.1 \mathrm{~b}$ and $\mathrm{c}$ ). Relative to the 17-wk-old animals, anti-CD40L antibody treatment also completely inhibited lipid core expansion (fig. 7.1d). During antiCD4OL antibody treatment, collagen content, ASMA content, and fibrous cap thickness increased as compared with the 17 -wk-old control-treated group (59\%, $392 \%$, and $183 \%$, respectively) $(p<0.05)$ (fig. 7.1 e-f). These data reveal that anti$\mathrm{CD} 40 \mathrm{~L}$ antibody treatment can modify the lesion profile from lipid-rich collagen-poor lesions into a lipid-poor, collagen-rich stable plaque phenotype.

\section{TGF $\beta$}

Because TGF $\beta$ is known to reduce inflammation and induce tissue fibrosis and extracellular matrix synthesis ${ }^{18}$, we hypothesized that anti-CD4OL antibody treatment induces up-regulation of TGF $\beta$, thereby contributing to the stable atherosclerotic plaque phenotype. In support of that hypothesis, anti-CD40L antibody-treated mice showed an increased TGF $\beta 1$ immunoreactivity in macrophage-rich lesions of advanced lesions, whereas fibrous regions did not stain for TGF 1 (fig. $7.3 \mathrm{a}$ and b).

\section{Discussion}

The present study describes the effects of both early and delayed treatment with an anti-CD40L antibody in a mouse model of atherosclerosis. First it reveals that interruption of the CD40L-CD40 pathway does not inhibit lesion initiation or agerelated increase in lesion area, especially because anti- CD40L antibody treatment 
affected neither initial lesion area nor phenotype in early and delayed treatment groups. Secondly, anti-CD 4OL antibody treatment results in the development of a lipid-poor, collagen-rich adwanced stable plaque phenotype, with a reduced Tlymphocyte and macrophage content. The observation that the change of phenotype was most profound in advanced lesions of the delayed treatment group stresses the importance of CD 40-CD 4OL signaling in late atherosclerotic changes.

The lipid-poor collagen-rich atherosclerotic plaque phenotype is concordant with the phenotype we observed after complete genetic disruption of CD4OL-CD40 signaling. " In the present manuscript, we show that anti-CD40L antibody treatment results in the development of a similar stable plaque phenotype. Moreover, we show that anti-CD40L antibody treatment is able to transform lipid-rich established atheromata into the lipid poor collagen-rich stable plaque phenotype, implying a beneficial role for anti-CD4OL antibody in the treatment of humanatherosclerosis.

Activation of CD4OL-CD40 signaling is associated with upregulation of proinflammatory pathways, important in the progression of atherosclerosis and plaque destabilization. First, after activation of CD4OL-CD40 signaling. TIymphocytes and macrophages produce several proatherogenic chemokines (MCP. 1. IL-8, PANTES) and cylokines (TNFo, $\| L-6) .10$ Second, activation of the CD40CD40L pathway in endothelial cells results in the upregulation of intercellular adhesion molecule, wascular cell adhesion molecule, and E-selectin ${ }^{12-14}$, and third. CD40-CD4OL signaling induces the up-regulation of matrix metalloproteinases (MMP 1, 3, 6, 9) ${ }^{9} 11$ These substances are associated with plaque macrophage recruitment, expansion of the lipid core, inhibition of collagen synthesis, and degradation of the fibrous cap in vivo. ${ }^{19}$ Inhibition of pro-inflammatory pathways might therefore have caused the observed lipid-poor, collagen-rich plaque phenotype. Furthermore, both activated platelets and fresh thrombi express high levels of $\mathrm{CD}_{40 L}{ }^{20}$, and T-Cell-mediated activation of the CD4OL-CD40 system results in the upregulation of tissue factor in macrophages and VSMCs. ${ }^{11.21}$ Patients suffering from unstable angina show elevated levels of degranulated platelets and SCD4OL plasma levels. ${ }^{22}$ Therefore, CD4OL-CD40 signaling may induce a procoagulant stage, a feature favoring the development of plaque rupture and thrombosis. 23

Another postulated mechanism responsible for the change into a more stable plaque phenotype may be a different pattern of cell turnover. The influence of CD40L-CD40 sighaling on cell turnover is, however, contradictory. It stimulates proliteration of $\mathrm{B}$ cells and Burkitt"s ymphoma cells, whereas it inhibits proliferation of B-cell lymphoma cells. ${ }^{24-26}$ Furthermore, CD40 regulates apoptosis in a dual fashion "depending on the upregulation of apoptosis resistance factors. ${ }^{24}$ In the present study, anti-CD4OL antibody treatment did not affect cell turnover, because total cell number and the level of DNA synthesis and apoptosis did not differ from control-treated animals. Alternatively, anti-CD4OL antibody treatment might cause cell turnover of specific cell types (VSMC), thereby resulting in a different plaque phenotype. Selectivity of both DNA synthesis and apoptosis in atherosclerosis was shown before in ApoE"3Leiden mice, where both DNA-synthesis and apoptosis are confined to macrophage-derived foam cells. ${ }^{17}$ However, in the present study, too, DNA-synthesis and apoptosis were contined to the macrophage, making 
involvement of the CD4OL-CD40 system in cell lurn-over during atherogenesis unlikely.

Interestingly, our study showed an increased immunoreactivity of TGFB1 in lesions of anti-CD4OL antibody-treated mice. Effects of TGF on atherosclerosis are, however, contradictory. On the one hand, TGF3 seems to have anti-atherogenic effects, because it prevents atherosclerosis in animals ${ }^{27,28}$ and because patients with severe coronary artery disease express low levels of TGF3 ${ }^{29}$ in addition, TGF $\beta$ can stimulate the synthesis of several extracellular matrix proteins ${ }^{30,31}$, inhibit the expression of matrix metalloproteases, enhance the expression of tissue inhibitors of matrix metalloproteinases (TIMPs) ${ }^{32}$, and induce tissue fibrosis ${ }^{33}$. Therefore, upregulation of TGF 3 might be responsible for the development of collagen-rich stable atherosclerotic plaques after anti-CD4OL antibody treatment by stimulation of collagen production and inhibition of collagen degradation (down-regulation of MMPS and up-regulation of TIMPS). On the other hand, TGF $\beta$ and its receptors were abundantly expressed in human fatty streaks and fibrofatty lesions ${ }^{34}$, and TGF $\beta$ induces the production of lipoprotein-trapping proteoglycans ${ }^{35}$, indicating a stimulatory role of TGF $\beta$ in the progression of atherosclerosis.

Although we and others report an increase of plaque collagen content after inhibition of CD 40-CD4OL signaling. ${ }^{76}$, it has been shown that anti-CD40L antibody treatment prevents lung fibrosis after irradiation-induced injury. ${ }^{37}$ Although we have no clear explanation for this phenomenon, the different tissue characteristics (artery vs. lung) and the different pathoglenesis of the two models might play a role. In both models, inhibition of CD40-CD40L signaling results in a down-regulation of inflammation. However, in atherosclerosis, anti-CD40L antibody treatment results in the upregulation of TGF $\beta$, a molecule known to induce collagen synthesis, whereas in irradiation-induced lung injury, a down-regulation of TGFB is suggested ${ }^{37}$

In conclusion, we have shown that inhibition of CD40L-CD40 signaling in mice with advanced atherosclerotic lesions results in the development of a lipid-poor collagen-rich stable plaque phenotype. Therefore, treatment with an anti-CD4OL antibody in humans might be beneficial, not by inhibiting lesion initiation or progression, but by transforming unstable plaques into stable atherosclerotic lesions, thereby reducing the acute complications of atherosclerosis.

\section{Acknowledgements}

This study was sponsored in part by the Wynand Pon Foundation, Leusden, The Netherlands.

\section{References}

1. Foy T M. Aruffo A, Bajorath J. Buhlmann JE, Noelle RJ. Immune regulation by CDAO and its ligand GP 139. Annu Fev Immunol 1996, 14:591-617

2. Aruffo A, Farrington M, Hollenbaugh D. Li X. Milatovich A, Nonoyama S. Bajorath J. Grosmaire LS. Stenkamp R, Neubauer M. Roberts RL. Noelle PJ. Ledbetter JA. Francke U, Ochs HD. The CD40 ligand, gp 139, is defective in activated $T$ cells from patients with $X$-linked hyper-lgM syndrome. Cell 1993:72:291-300 
3. Durle FH, Fava RA, Foy TM, Aruto A, Ledbetter JA, Noelle RJ. Prevention of collagen-induced arthritis with an antibody to gp39, the ligand for CD40. Science 1993:261:1328-1330.

4. Gerrise $K$, Laman JD, Noelle R, Aruffo A, Ledbetter JA. Boersma WJA, Claassen E. CD40-CD40 ligand interactions in experimental allergic encephallitis and muitiple scterosis. Proc Nath ACad SciU S A 1996,932499-2504.

5. Larsen CP. Elwood ET, Alexander DZ, Ritchie SC, Hendrix R, Tucker-Burder C, Cho HR. Arufto $A_{3}$, Hollenbaugh D, Lingley PS, Winn KJ, Pearson TW. Long-term acceptance of skin and cardiac allografts after blocking $\mathrm{CO} 40$ and $\mathrm{CD} 28$ pattways. Nalure 1996:381:434-438.

6. Reul RM, Fang UC. Denton MD, Geehan C, Long C, Mitchell RM, Ganz P. Briscoe DM. CD40 and CD40 ligand (CD154) are coexpressed on microvessels in vivo in human cardiac allografi fejection. Transplantation 1997;64:1765-1774.

7. Lutgens E, Gorelik L, Daemen MJAF", de Muinck ED, Grewal IS, Koteliansky VE, Flavell RA. Requirement for CD154 in the progression of atherosclerosis. Nat Med 1999:5:1313-1316.

8. Mach F, Schörbeck U, Sukhova GK, Atkinson E, Libby P. Reduction of atherosclerosis in mice by irihibition of CD40 signaling. Nature 1998;394:200-203.

9. Schonbeck U, Mach F. Sukhova GK, Murphy C. Bonneioy JY" Fabunmi RP, Libby P. Regulation of matrix metalloproteinase expression in human vascular smooth muscle cells by $T$ lymphacytes. A role for CD40 signaling in plaque rupture? Circ Res 1997:81:448-454.

10. Mach F, Schönbeck U, Sukhowa GK, Bourcier T. Bonnetoy JY, Pober JS, Libby P. Functionall CD40 ligand is expressed on human vascular endothelial cells, smooth muscle cells and macrophages. Proc Nall Acad Sci US A 1997; 94: 1931-1936.

11. Mach F. Schonbeck U. Bonnefoy JY. Pober JS, Libby P. Actiwation of monocyte/macrophage functions related to acute atheroma complication by ligation of $\mathrm{CD} 40$. Induction of collagenase. stromelysin, and tissue factor. Circulation 1997;96:396-399.

12. Kombluth $\mathrm{A}$, Kee K. Richman DD. CDA0 ligand (CD 154) stimulation of macrophages to produce HiV-1-suppressive 3-chemokines. Proc Natl Acad Sci US A 1998;95:5205-5210.

13. Alderson MR, Armilage R." Tough TW, Strockbine L, Fanslow WC. Spriggs MK. CD40 expression by human monocytes: Regulation by cytokines and activation of monocytes by the ligand for CD40. J Exp Med 1993:178:669-674.

14. Yellin MJ Brett J, Baum D, Matsushima A. Szabolcs M, Stern D. Chess L. Functionall interactions of T-lymphocytes with endothellial cells: The role of CD40-CD4OL mediated signals. I Exp Med 1995:182:1857:1864.

15. Ross R. Atherosclerasis. An inflammatory disease. N Engl J Med 1999;340:115-126.

16. Stary $H C$, Chandler $A B$. Dinsmore RE, Fuster $V$, Glagov $S$, Insull W Jr. Rosenfeld ME, Schwartz CJ. Wagner WD, Wissler RW. A definition of advanced types of atherosclerotic lesions and a histological classification of atherosclerosis. A report from the Committee on Vascular Lesions of the Council on Arteriosclerosis. American Heart Association. Arterioscler Thromb Vaso Biol 1995: 15:1512-1531.

17. Lutgens E, Daemen M. Kockx M, Doevendans P. Hofker M. Havekes L. Wellens $H$, de Muinck E. Atherosclerosis in APOE"3 Leiden transgenic mice: from proliferative to atheromatous stage. Circulation 1999,99:276-283.

18. Wahl SM. Transforming growth factor beta: the good, the bad, and the ugly. $y$ Exp Med 1994:180: 1587-1590.

19. Libby P. Molecular bases of the acute coronary syndromes. Circulation 1995; 91:2844-2850.

20. Henr V. Slupsky JR, Grate M., Anagnostopoulos I. Forster R. Muller-Berghaus, G. \& Kroczek, R. A. CD40 ligand on activated platelets triggers an inflammatory reaction of endothelial cells. Nature 1998; $391: 591-594$

21. Schonbeck U, Mach F. Sukhova GK, Herman M. Graber P, Kehry MF, Libby P. CD40 ligation induces tissue factor expression in human vascular smooth muscle cells. Am I Pathot $2000: 156: 7-14$.

22. Aukrust P. Muller F. Ueland T, Berget T, Aaser E. Brunswig A. Solum NO. Forfang K, Freland SS. Gullestad L. Enhanced levels of soluble and membrane-bound CD40 ligand in patients with unstable angina. Possibie reflection of $T$ lymphocyle and platelet involvement in the pathogenesis of acute coronary syndromes. Circulation 1999:100:614-620.

23. Libby P. Mack F. Schonbeck U. Bourcier T. Aikawa M. Regulation of the thrombotic potential of atheroma. Thromb Haenostasis 1999;82:736-741. 
24. Hess S, Gottfied E. Smola H. Grunwald U. Schuchmann M. Engelmann H. OD40 induces resistance to TNF mediated apoplosis in a fibroblast cell line. Eur J/mmumol 1998;29:3594-3604.

25. Rathmell JC, Townsend SE, XU JC. Flavell RA, Goodnow CC. Expansion or elimination of B-Cells in viwo: dual role for CD40- and Fas (CD95)-ligands modulated by the B cell antigen receptor. Cell 1998;87:319-329.

26. Valentine MA, Licciardi KA. Rescue from antilgM-induced programmed cell death by the $B$-cell surface proteins CD20 and CD40. Eur J immuno: 1992;22:3141-3148.

27. Reckless J. Metcalle JC. Grainger DJ. Tamoxifen decreases cholesterol sevenfold and abolishes lipid lesion development in apolipoprotein $E$ knockout mice. Circulation 1997:95:15421548.

28. Grainger DU, Kemp PR, Liu AC, Lawn RM. Metcalte JC. Activation of transforming growth factorbeta is irhibited in transgenic apolipoprotein(a) mice. Nature 1994:370:460-462

29. Grainger DJ Kemp PR, Metcalfe JC, Liu AC, Lawn RM. Williams NR, Grace AA, Schotield PM, Chauhan $A$. The serum concentration of active transforming growth factor-beta is severely depressed in advanced atherosclerosis. Nat Med 1995; 1:74-79.

30. Smith JD. Bryant SR, Couper LL. Vary CPH. Gotwals PJ, Koteliansky VE, Lindner V. Soluble transforming growth factor-beta type II receptor inhibits negative remodeling. fibroblast differentiation and intimal lesion formation, but not endotheliai growth. Circ Res 1994;84:1212 1222

31. Schulick A.H. Taylor A.l, Zuo W, Qiu C. Dong G. Wooclward PN, Agah P, Roberts AB, Virmani A. Dichek DA. Overexpression of Iransforming growth factor $\beta 1$ in arterial endothelium causes typerplasia, apoptosis and cartilaginous metaplasia. Proc Nall Acad Sol U S A 1998;95:69836988.

32. Stearns ME, Phim J. Wang M. Interleukin 10 (IL-10) inhibition of primary human prostate cellinduced angiogenesis: IL-10 stimulation of tissue inhibitor of metalloproteinase- 1 and inhibition of matrixmetalloproteinase (MMP)-2/MMP-9 secretion. Clin Cancer Res 1999;5:189-196.

33. Border WA, Noble NA. TGFB in tissue fibrosis. NEngl M Med 1994:331:1286-1292.

34. Bobik $A$. Agrotis $A$, Kanellakis $P$. Dilley $A$, Krushingky A, Smimov $V$, Tararak $E$, Condron $M$, Kostolias $G$. Distinct patterns of transforming growth factor beta isoform and receptor expression in human atherosclerotic lesions. Circulation 1999;99:2883-2891.

35. Leonarduzzi G. Scavazza A, Biasi F, Chiarpotto $\mathbb{E}$, Camandola $S$, Vogel $S$. The lipid peroxidation end product 4-hydroxy-2,3-nonenal up-regulates transforming growth factor betal expression in the macrophage lineage: a link between oxidative injury and fibrosclerosis. FASEB if $1997: 11: 851-857$.

36. Schönbeck $U$. Sukhova GK, Shimizu K, Mach F, Libby P. Inhibition of CD40 signaling limits evolution of established atherosclerosis in mice. Proc Natl ACad SCi U S A 2000;97:7458-7463

37. Adlawi A, Zhang Y. Baggs R, Rubin P. Williams J, Finkelstein J, Phipps FP. Blockade of CD40CD40 ligand interactions protects against radiation-induced pulmonary inflammation and fibrosis. Clin Immunol immunopathol 1998:89:222-230. 
Chapter 8

General Discussion

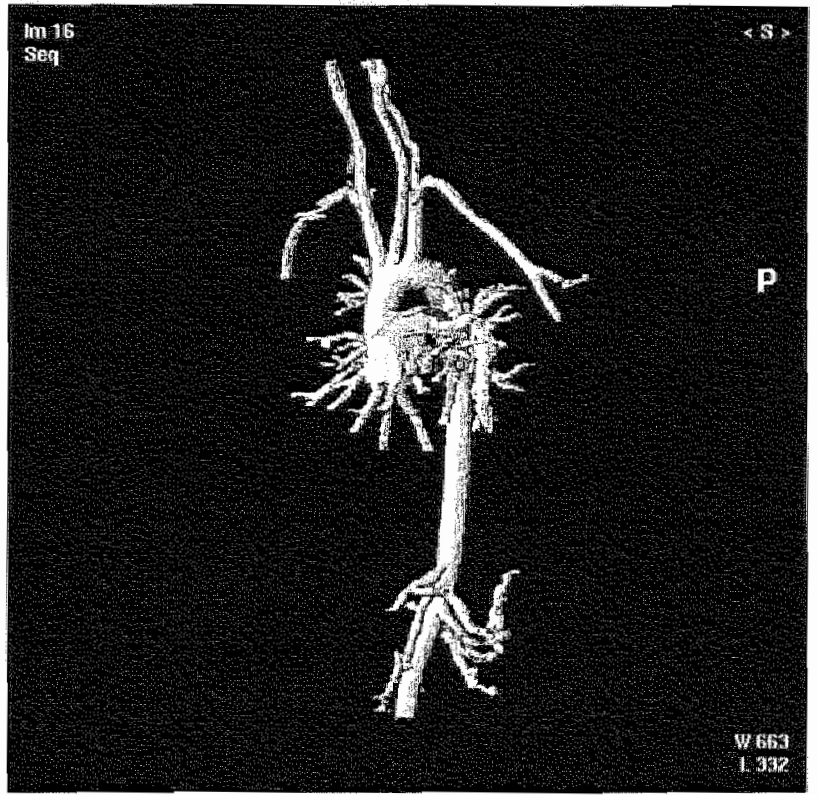




\subsection{Introduction}

In this thesis, we characterized several hyperlipidemic mouse models and investigated the role of cell turnover and inflammation on atherosclerotic plaque progression and phenotype in these models. Cell turnover was also studied in fuman atherosclerotic plaques.

The main findings of these sludies are that:

1. ApoE*3Leiden mice show a cranio-caudal atherosclerotic lesion progression, with plaque development predominantly at aortic branchpoints.

2. Both ApoE-/- and ApoE*3Leiden mice develop arterial compensatory enlargemenit and carotid artery stenosis, but fail to develop constrictive remodeling.

3. In both ApoE*3Leiden mice and humans, DNA-synthesis is an early feature of atherosclerosis, while apoptosis is a late phenomenon. The cell-type that predominantly exhibits DNA-synthesis and apoptosis is the macrophage.

4. An interwention study with genetic inhibition of Gas6, a survival factor, does not exert effects on cell turnover, but results in the development of a differently organized plaque with a rupture prone plaque phenotype.

5. Inhibition of a major regulator of inflammatory and immune reactions, the CD40CD4OL system, results in the development of a lipid-poor, collagen-rich, stable plaque phenotype.

\section{New insights into the pathogenesis of atherosclerosis}

\subsection{Cell turnover during atherogenesis. Is it important?}

In 1858, R. Virchow, the founder of cellular pathology stated, that cell proliferation and cell death were important players in the pathogenesis of atherosclerosis. "Later, DNA-synthesis and apoptosis (programmed cell death) were observed in several model systems of atherosclerosis. However, even at present, the question whether cell turnover is a key event in atherosclerosis remains largely unanswered.

\subsubsection{DNA-synthesis}

Since the evolvement of the "response to injury' hypothesis (chapter 1). atherosclerotic plaques were considered to arise by proliferation of cells within the arterial intima in response to injury. ${ }^{2,3}$ Evidence for this hypothesis was obtained from data of model systems of arterial injury, predominantly the balloon injured rat carotid artery." As the "response to injury' hypothesis stated, arterial injury caused elevated levels of DNA-Synthesis for weeks to months after the injury, resulting in neointima formation. ${ }^{5}$ Substances responsible for proliferation and neointima formation were identified, like PDGF, FGF and angiotensin $11^{6-8}$ Furthermore, intervention studies with their antagonists, as well as gene transfer studies with cellcycle inhibitors (like p21,p27) were successful in inhibiting DNA-synthesis and in reducing neointima formation in the rat model..$^{8-10}$

At that time, the rat arterial injury model was considered as a model system for the pathogenesis of primary atherosclerosis, but only little evidence for a role of 
DNA-synthesis in primary atherosclerosis could be oblained. In fatfed swine and rabbits, a transient increase in DNA-synthesis, with peak levels around $5 \%$ was observed ${ }^{11.12}$, whereas studies in human primary atherosclerotic lesions show that levels of DNA-synthesis were extremely low $(0-2 \%)^{13-17}$ Although interventions in model systems of arterial injury were successful, these positive results could not be duplicated in primary atherosclerosis. Thus, the role of DNA-synthesis in the pathogenesis of primary atherosclerosis remains questionable. However, there are several possible explanations for the apparent discrepancy in DNA-synthesis levels between arterial injury models and primary atherosclerosis.

First of all, in contrast to arterial injury models, atherosclerosis is a slowly developing disease, taking decades to become clinically manifest. Hence, the low level of DNA synthesis during primary atherogenesis as opposed to the process of neointima formation alter balloon injury, may be explained by the rapidity of onset of neointima formation. This may require a short lasting burst of intensive DNA synthesis, while in the chronic process of atherogenesis, a low level DNA synthesis that is maintained for many years may contribute significantly to the progression of the disease.

Alternatively, it is possible that DNA-synthesis is important in some "but not all stages of atherosclerosis ${ }^{3,18}$, for example during lesion initiation, or during plaque repair. Interestingly, in ApoE*3Leiden mice, as well as in humans, we observed a peak in DNA-synthesis in early type II (fatty streak) lesions. ${ }^{17.99}$ This peak of early DNA-synthesis was consistent with the transient peak observed before in the fat-fed swine and rabbit. ${ }^{11.12}$ This early peak in DNA-synthesis was not observed before in human atherosclerotic lesions. Since most of the studies focused on advanced atherosclerotic lesions ${ }^{13-16}$, an early proliferative peak may have been missed. In vitro studies revealed that macrophages obtained from human fatty streak lesions. exhibited increased DNA-synthesis compared to cells obtained from advanced atheromata. $^{20}$

The question still remains, whether this early DNA-synthesis peak is important in the pathogensis of atherosclerosis. The early DNA-synthesis peak might imply that proliferation is important in the early stage of atherosclerosis. Therefore, at least in theory, it can be postulated that administration of anti-proliferative drugs in atherosclerosis would be beneficial, when applied early in the disease, and maintained for a longer period of time. However, systemic administration of antiproliferative drugs (for example cell cycle imhibitors) for a longer period most likely disturbs other (patho)physiological processes, like wound healing and cell regeneration. Vascular-specific administration of these drugs by such techniques as gene transfer may overcome this pitfall. Due to undesirable side-effects of the systemic approach, an antiproliferative therapy to halt the progression of primary atherosclerosis in the entire vasculature would be impractical. As stated before. several anti-proliferative drugs have been employed successfully in various animal models to prevent restenosis and hold considerable promise for clinical application. When applied locally at the site of vessel wall injury. systemic side effects are avoided to a great extent and the concentration of the drug in the vessel wall is increased significantly as compared to the concentration after systemic administration. 
Another observation that suggests that low levels of DNA-synthesis do contribute to the progression of primary atherosclerosis, is that plaques contain a large monoclonal population of cells. This phenomenon was first observed by $\mathbb{E}$. Benditt et al. in 1973. ${ }^{21}$ The studies were based on the hypothesis that one $X$ chromosome is randomly inactivated in early female development, and that all progeny from that cell retain the same inactivated $X$-chromosome. ${ }^{21}$ Female tissue is thus a mosaic of cells bearing either an inactive paternal or maternal $X$ chromosome. These properties make X-chromosome inactivation a very useful assay to distinguish polyclonal from monoclonal lesions. In advanced female human atherosclerotic lesions, SMCs exhibited the same X-chromosomal activation pattern, and were considered to be monoclonal. ${ }^{21}$ Several mechanisms for the development of monoclonality have been proposed. First of all, atherosclerosis could arise from a pre-existing clone of cells if the stimulus for proliferation is contained within a single patch of SMCs. ${ }^{21-23}$ On the other hand, it is possible that plaque SMCs initially are polyclonal, but transform by a virus or chemical mutagen, thereby inducing selective proliferation of a single cell."23 Lastly, and most likely, it is possible that SMCs of the normal arterial media are polyclonal, i.e. belonging to multiple lineages of which one is uniquely suited to form the plaque. In this view, monoclonality would result from the selection of a particular cell lineage either on the basis of proliferation, migration or survival. ${ }^{23,24}$ All the theories described above have one thing in common: monoclonality can only result from many generations of cell replication.22 Since atherosclerotic plaques take several decades to become advanced lesions, the relative low levels of DNA-synthesis might still be an important feature in the pathogenesis of atherosclerosis.

There are also arguments that support the view that the contribution of the low levels of DNA-synthesis to plaque progression and phenotype is limited. This is also reflected by the in vivo experiments described in this thesis.

Genetic disruption of Gas6, a survival factor "known to induce DNA-synthesis in serum slarved fibroblasts ${ }^{25}$, has no effects on the levels of DNA-synthesis in atherosclerotic plaques in the ApoE-1-mouse (chapter 5). Furthermore, absence of Gas6 lails to inhibit lesion development or progression. Surprisingly, it induced the development of an altered atherosclerotic plaque phenotype. Atherosclerotic lesions of Gas6-/-/ApoE-/- mice were differently organized and exhibited an increased collagen deposition. The most remarkable feature of this phenotype, never observed before in ApoE-1- mice. was the development of intraplaque hemorrhage, associated with fibrin and iron deposition. Although intraplaque hemormage does not reflect plaque rupture, the phenotype indicates that absence of Gas6 might induce plaque instability in mouse atherosclerotic lesions.

In two other studies (chapters 6 and 7 ), we report that inhibition of CD40-CD4OL interactions resulted in the development of a lipid-poor, collagen-rich, stable plaque phenotype. ${ }^{26,27}$ One might expect that a change in DNA-synthesis would contribute to the observed phenotype. However, inhibition of CD40-CD40L signaling did not affect total plaque cell number nor plaque DNA-synthesis.

Other interesting findings of our cell turnover studies were the cell type that exhibits DNA-synthesis and the distribution of DNA-synthesis in the atherosclerotic 
plaque. Although it was thought for a long time, that the SMC was the major cell type that exhibited DNA-synthesis in primary atherosclerosis', data obtained from our $\mathrm{lab}^{17,19}$, and others ${ }^{13,16}$, imply that the macrophage derived foam cell is the cell-type that predominantly exhibits DNA-synthesis. DNA-synthesis in SMCs was hardly observed, although our immunohistochemical stainings may not be completely conclusive. First, it cannot be excluded that some of the foam cells that are positive for our macrophage antibodies are of SMC origin, since SMCs can oblain macrophage markers during foam cell formation. ${ }^{28}$ Second, some of the plaque SMCs have been missed, since they might not contain $\alpha$-smooth muscle actin.

The data described in this thesis, and data described by others, imply other explanations than plaque progression, for the limited increase in DNA-synthesis in primary atherosclerosis. These include cell-repair instead of cell proliferation, and plaque repair instead of plaque growth. In vitro, it was shown that macrophages exposed to oxLDL, the cell type in which we predominantly observed DNAsynthesis, develop DNA-damage, and a mitogenic response. ${ }^{29}$ Furthermore, in our mouse intervention studies, we saw no effects on total cell number, indicating that altered cell-division rates did not occur (chapters 5-7). ${ }^{26,27}$ The early proliferative peak observed in early atherosclerosis in ApoE*3Leiden mice, might very well be the result of a repair mechanism, especially since BrdU incorporation does not necessarily reflect cell division ${ }^{19}$, but may also indicate cell repair. Furthermore, we ${ }^{17,19}$, and also others ${ }^{16}$ observe DNA-synthesis predominantly at sites with recent damage, such as plaque rupture, indicating plaque repair.

\subsubsection{Apoptosis}

The presence of apoptosis in the intima was first postulated by Clowes et al. $(1983)^{30}$ in the balloon injured rat carotid, on the basis of the level of DNA-synthesis and the actual number of cells. Later, when the techniques for the detection of apoptosis, such as DNA-laddering and the TUNEL technique had developed, increased numbers of apoptotic cells were observed in arterial injury models, as well as in primary atherosclerotic lesions of hyperlipidemic animal models and humans. ${ }^{31-34}$

In this thesis, we confirmed the presence of apoptosis in atherosclerotic lesions of mice and humans by the TUNEL technique. ${ }^{17.19}$ As already observed by athers ${ }^{31.33 .34}$, elevated levels of apoptosis were only present in advanced stages of atherosclerotic lesions. Furthermore, in ApoE* 3 Leiden mice, apoptosis was confined to macrophage derived foam cells in the lipid core area, whereas in humans, apoptosis was equally distributed between the macrophage derived foam cell in the lipid core area and the SMC in the fibrous cap. ${ }^{17,19}$

However, caution should be paid to the interpretation of the TUNEL results. Altough the TUNEL technique does stain apoptotic nuclei, it also stains necrotic cells, and cells undergoing RNA-splicing. ${ }^{35}$ However, we only considered a cell to be apoptotic when it exhibits, besides TUNEL staining. morphological fealures of apoptosis (chapter 1). Furthermare the group of Kockx et al. applied a series of apoptotic markers on atherosclerotic plaques, and obtained comparable results. ${ }^{36}$ Therefore, the data described in this thesis reflect the actual amounts ofapoptosis. 
As with DNA-synthesis, the exact role of apoptosis in the pathogenesis of atherosclerosis is not clear. Theoretically, apoptosis might be beneficial, by inducing regression of atherosclerotic lesions. However "since apoptosis is predominantly present in the lipid core and fibrous cap area, it might also be detrimental, and induce plaque instability. Apoptosis of macrophage derived foam cells in the lipid core area might contribute to lipid core expansion, whereas apoptosis of VSMC in the fibrous cap area might result in thinning of the fibrous cap. both features contributing to plaque rupture. The thinining of the fibrous cap is likely to be a result of a decreased VSMC density and a decreased cap extracellular matrix content. ${ }^{37.38}$

In vivo experiments investigating whether apoptosis in atherosclerosis is beneficial or detrimental, are scarce and not conclusive. However, in arterial injury models, intervention studies with overexpression of apoptosis promoting agents (Fas, NO) $)^{39,40}$ and inhibition of apoptosis inhibiting agents (Bcl-2 and $\left.\mathrm{BCl}-\mathrm{x}\right)^{41}$ revealed a decrease in neointima formation, indicating an important role for apoptosis in the pathogenesis of arterial injury.

Recently, Schneider et al. administered FasL to hypercholesterolemic rabbits, which contain primary atherosclerotic lesions. Surprisingly, levels of apoptosis were not affected, and atherosclerosis was even accelerated, due to an increased expression of VCAM-1, and an increased SMC proliferation, indicating ather functions of FasL than apoptosis. ${ }^{42}$

The role of other apoptotic mediators in atherosclerosis, is until now not confirmed by in vivo experiments. As can be concluded from the intervention studies performed in this thesis, the contribution of apoptosis in atherosclerosis seems to be limited. Genetic disruption of Gas6 resulted in a slight decrease of apoptosis in advanced atherosclerotic lesions, whereas the phenotypical characteristics indicate plaque instability. Furthermore, both genetic and pharmacological inhibition of CD40-CD4OL signaling did not affect apoptosis levels, although decreased levels of apoptosis would be expected, since CD40L-inhibition induced an increased fibrous cap thickness, and a decreased lipid core content. 26,27

\subsection{CD40-CD40L interactions}

The CD40-CD4OL system is an important regulator of inflammation and the immune system. Since inflammation is considered to play a major role in the pathogenesis of atherosclerosis (chapter 1), a role for CD40-CD40L interactions in atherosclerosis was postulated.

In this thesis, the proposed role for the CD40-CD4OL system in atherosclerosis. described in chapter 1 , is confirmed. In chapter 6 , we describe the effects of genetic disruption of the CD40-CD4OL system, and found that absence of the CD4OL gene in ApoE-1- mice resulted in a 5.5-fold decrease in atherosclerotic plaque area compared to normal ApoE-1- mice. ${ }^{26}$ Moreover, advanced atherosclerotic lesions in these mice showed a lipid-poor, collagen-rich, stable plaque phenotype, with a decreased macrophage and T-lymphocyte content. In a follow-up study (chapter 7), we were able to show that also pharmacological 
interruption of CD40-CD4OL signaling (anti-CD40L antibody reatment), induced the development of a lipid-poor, collagen- SMC- and chondrocyte rich plaque phenotype, a phenotype quite similar to that in CD4OL-/-/ApoE-/- mice. ${ }^{27}$ This phenotype could even be established when antibody treatment was delayed until advanced plaques had developed. The group of Libby et all. showed similar results. ${ }^{43,44}$

Since in humans, most of the complications of atherosclerosis are the result of plaque instability (chapter 1$)^{45}$, anti-CD $40 \mathrm{~L}$ antibody treatment might be beneficial in preventing the acute complications of atherosclerosis. It may not decrease plaque area or the number of lesions, but is likely to transform the lipid-rich, collagen-poor vulnerable plaque, into a more stable plaque phenotype. This would have profound effects on atherosclerosis related mortality and morbidity.

Several mechanisms for the development of this stable plaque phenotype have been proposed. First of all, in vitro data and immunohistochemical analysis revealed a downregulation of pro-inflammatory pathways, responsible for lesion initiation. progression and plaque destabilisation. ${ }^{46}$ Furthermore, we described that antiCD4OL antibody treatment in mice induced the upregulation of TGF $\beta{ }^{47}$ TGF $\beta$ promotes collagen synthesis, but also exerts other functions, like cell (trans)differentiation and the induction of wound healing, factors contributing to a stable plaque configuration. ${ }^{48}$ However, precise mechanisms responsible for the development of this plaque phenotype still need to be elucidated.

\subsubsection{Postulated mechanisms: preliminary results obtained from cDNA expression array analysis}

To further elucidate factors that may play a role in the development of the CD40CD4OL inhibition induced stable plaque phenotype, CDNA expression array analysis (Atlas ${ }^{\text {TM }}$ mouse CDNA array $7741-1$, Clontech, Palo Alto, USA) was performed on the atherosclerotic aortic arch of anti-CD4OL antibody treated mice $(n=3)$ and control treated mice $(n=3)$. cDNA-array analysis is a method suitable for the rapid assessment of mRNA expression of a large number of genes. ${ }^{49}$ This method has already been proven to be successful to evaluate disease related changes in gene expression in several other areas such as cancer ${ }^{50}$, rheumatoid arthritis, inflammatory bowel disease ${ }^{51}$ and myocardial infarction ${ }^{52}$

Analysis revealed that anti-CD $40 \mathrm{~L}$ antibody treatment induced differential mANA expression patterns of genes with different functional subsets as described below.

\section{Inflammation}

As expected, anti-CD40L antibody treatment resulted in the downregulation of several pro-inflammatory genes, and especially those involved in macrophage and T-lymphocyte activation (table 8.1). For example, the expression of Mip53, a chemokine that plays an important role in macrophage chemotaxis and activation, is completely blocked by anti-CD4OL antibody treatment. Also thrombopoietin, IGF$1 A^{39}$ and IGFBP6 ${ }^{39}$, which induce enhanced expression of VCAM, ILIB, IL6 and TNF $\alpha$, show decreased expression ${ }^{54}$, while expression of negative cytokine regulators, like NF-E $2^{55}$ and TGF $\beta^{48}$ was increased. 
Table 8.1

Expression patten of genes inwolved in inflammation

\begin{tabular}{ll}
\hline Genes & $\begin{array}{l}\text { Expression } \\
\text { compared to control } \\
\text { treatment }\end{array}$ \\
\hline MPF & 0.0 \\
Thrombopoietin & -2.5 \\
IGF-1A & -3.0 \\
IGFBP-6 & -2.7 \\
NF-E2 & 2.2 \\
TGFB & 2.4 \\
AAG-1 & -3.6 \\
Cathepsin D & -2.2 \\
Prothymosin $\alpha$ & -6.3 \\
LKLF & 2.3 \\
CTLA 4 & 2.1 \\
IL.6 receptorigp 130 & 3.9 \\
GM-CSF & 6.9 \\
GM-CSF receptor & 2.0 \\
CD14 & 5.5 \\
ICE & 3.1 \\
ACE & 3.5 \\
IAF 1 & $>>50$ \\
\hline
\end{tabular}

The expression of RAG-1, a gene responsible for the activation and maturation of $T$ - and B-lymphocytes ${ }^{56}$ and for the assembly of immunoglobulins and $T$. lymphocyte receptors ${ }^{57}$. was decreased after anti-CD $40 \mathrm{~L}$ antibody treatment, as well as the expression of cathepsin D and prothymosin $\alpha$, genes involved in antigen presentation $^{58}$ and T-lymphocyte activation ${ }^{59.60}$, respectively. Interestingly, LKLF ${ }^{61}$ and CTLA $4^{62}$, genes responsible for T-lymphocyte quiescence and inhibition of Tlymphocyte activation, displayed an enhanced expression.

Surprisingly, enhanced expression of pro-inflammatory genes such as the IL6 receptor/gp $130^{63}$,gm-CSF and the gm-CSF receptor ${ }^{64}, \mathrm{CD}_{1} 4^{65}, 1 \mathrm{CE} \mathrm{E}^{66}, \mathrm{ACE}^{67}$ and IFF-1 ${ }^{68}$ after CD40-CD40L blockade was also observed. Although most of these genes contain besides pro-inflammatory, also anti-inflammatory properties ${ }^{63,69}$, their enhanced expression might be the result of a positive feedback mechanism.

Interestingly, although CDNA-expression array analysis confirmed the importance of CD40-CD4OL interactions in inflammation in atherosclerosis, it also revealed differential expression patterns of inflammatory modulators that were not known to be associated with $\mathrm{CD} 40-\mathrm{CD} 4 \mathrm{OL}$ interactions or atherosclerosis.

\section{Cellular protection}

One of the subset of genes that displayed an enhanced mRNA expression after antjCD4OL antibody treatment, were genes involved in cellular protection under stress (table 8.2). For example, HSP 84 and $86^{70}$, and $\mathrm{Net}^{71}$, genes that stabilize intracellular processes under stress, were upregulated. Also gluthathione peroxidase ${ }^{72}$, gluthathione S-transierase ${ }^{73}$ and NF-E2 $2^{74}$, genes that protect cells 
Table 8.2

Expression pattern of genes involwed in cellular protection

\begin{tabular}{ll}
\hline Genes & $\begin{array}{c}\text { Expression compared } \\
\text { to control treatment }\end{array}$ \\
\hline HSP 84 & 27.3 \\
HSP 86 & 2.1 \\
Net & 4.9 \\
Gluhnathione peroxidase & 3.5 \\
Gluthathione S- & 2.2 \\
NF.E2 & 2.2 \\
MHF230 & 2.3 \\
\hline
\end{tabular}

against oxidative stress and exagenous chemicals, showed enhanced mRNA expression after anti-CD40L antibody treatment. We also observed upregulation of MHR23b, a gene responsible for the removal of damaged nucleotides. ${ }^{75}$

Since an important feature of atherosclerosis is the increase in oxidative stress, predominantly due to increased levels of $\mathrm{XxLDL}^{18}$, these data reveal that inhibition of the CD40-CD4OL system might increase the resistance of plaque cell types to oxidative stress.

\section{3. (Trans) differentiation and phenotype}

Plaque SMCs and macrophages undergo phenotypic modulation during atherosclerosis. Interestingly, anti-CD40L antibody treatment induced a differential gene expression pattern of genes involved in phenotypic modulation compared to normal plaque development (table 8.3).

Anti-CD4OL antibody treatment induced upregulation of genes involved in cell differentiation in general such as HSP $86^{76}$ and B-Raf ${ }^{77}$, as well as hematopoietic stem cell differentiation such as NF-E2 $2^{78}$ and $B K L F^{79}$.

Furthermore, after anti-CD4OL antibody treatment, genes encoding for different SMC phenotypical markers like sm-MHC ${ }^{80}$, the ski-proto-oncogene ${ }^{81}, \operatorname{TGF}^{82}$ and EGR-1 ${ }^{83}$ were upregulated, while other SMC phenotypic modulators like the bFGF receptor ${ }^{84}$ and IGF-1A $\mathrm{A}^{39}$, inhibin and its receptor follistatin ${ }^{85}$ showed decreased expression. UBF-1, a transcription factor involved in SMC hypertrophy was downregulated. ${ }^{86}$

Also genes inducing macrophage differentiation and maturation, such as LL6/gp $130^{97}, \mathrm{CD}_{1} 4^{65}$. EGR-1 ${ }^{86}$ and Flt-1 $1^{98}$ showed an increased expression after antiCD4OL antibody treatment, while the expression of cathepsin D and $\mathrm{L}$, both involved in foam cell formation, was decreased ${ }^{89}$

TGF $\beta$, a growth factor able to induce transdifferentiation of macrophages into a myofibroblast like phenotype $e^{50}$, or of SMC into chondrocytes ${ }^{91}$, displayed an enhanced mRNA and protein expression after anti-CD40L antibody treatment. 
Table 8.3

Expression of genes involved in (trans)differentiation and phenotype

\begin{tabular}{|c|c|}
\hline Genes & $\begin{array}{l}\text { Expression compared } \\
\text { to control treatment }\end{array}$ \\
\hline \multicolumn{2}{|l|}{ General } \\
\hline HSP BE & 2.9 \\
\hline Bual & 341 \\
\hline NF-E2 & 22 \\
\hline BKLF & $>>50$ \\
\hline \multicolumn{2}{|l|}{ SMC phenatype } \\
\hline$S M-M H C$ & 3.1 \\
\hline Ski-proto-oncogene & 5.0 \\
\hline TGF & 2.4 \\
\hline EGR-1 & $>>50$ \\
\hline BFGF & -3.8 \\
\hline IGF-IA & -3.0 \\
\hline Inthibin & -23 \\
\hline Follistatim & -23 \\
\hline UBF-1 & -9.1 \\
\hline \multicolumn{2}{|l|}{ Macrophage subset } \\
\hline IL6rec, gp 130 & 3.9 \\
\hline CD14 & 5.5 \\
\hline EGR-1 & $>>50$ \\
\hline Flt-1 & $>>50$ \\
\hline Cathepsin D & -2.2 \\
\hline Cathepsin L & -6.3 \\
\hline
\end{tabular}

\section{Extracellular matrix related mRNAs}

According to the increase in plaque extracellular matrix (ECM) content observed after anti-CD4OL antibody treatment ${ }^{26,27,44}$, a different expression pattern of genes encoding for cytoskeletal proteins, genes responsible for the synthesis of ECM, and genes involved in extracellular matrix turnover was observed (table 8.4).

First of all, anti-CD40L antibody treatment resulted in the upregulation of zyxin, a cyloskeletal protein that is involved in $\alpha$-actin filament assembly ${ }^{92}$ and EGR-1, a transcription factor responsible for the upregulation of fibronectin ${ }^{83}$, while the expression of the gene encoding for vimentin ${ }^{93}$, a gene associated with advanced atherosclerosis ${ }^{94}$, was decreased.

Second "transcription factors (EGR-1 and NF1 1 ) and genes favoring the deposition of ECM (TGFß and ACE) displayed an enhanced expression after antiCD4OL antibody treatment. ${ }^{95-97}$ 
Table 8.4

Genes involved in extraceliular matrix

\begin{tabular}{lc}
\hline Genes & $\begin{array}{c}\text { Expression compared } \\
\text { to control treatment }\end{array}$ \\
\hline Zyxin & 2 \\
EGR-1 & $>>50$ \\
Vimentin & -2.4 \\
NF-1B & $>>50$ \\
TGFB & 2.4 \\
ACE & 3.5 \\
Cathepsin D & -2.2 \\
Cathepsin L & -6.3 \\
TIMP 2 & 5.0 \\
TMMP 3 & 2.9 \\
\hline
\end{tabular}

Besides the increased expression of ECM-synthesis promating genes, genes involved in ECM degradation, like cathepsin $D$ and $L^{96}$. were downregulated, while genes encoding for inhibitors of ECM degrading enzymes (TIMP 2 and TIMP 3 ) showed an increased expression. ${ }^{99}$

These data suggest that anti-CD $40 \mathrm{~L}$ antibody treatment induces an increased ECM deposition, and a decreased degradation.

\section{Embryonic genes}

Upregulation of embryonic genes is a common feature of atherosclerosis. Interestingly, anti-CD4OL antibody treatment revealed a number of embryonic genes that displayed an enhanced expression, especially genes that were involved in mesenchymal patterning, such as $\mathrm{KIF}^{1} \mathrm{~B}^{100}$, Flt- ${ }^{101}$, and the ski-protooncogene (myoblast differentiation) ${ }^{81}$. Other embryonic genes that showed differential expression after treatment were LKLF (media and vessel stabilisation) ${ }^{102}$. NFE2 (hematopoietic development) ${ }^{103}, \mathrm{c}$-ErbA oncogene (myobllast differentiation) MLC fetal isoform (skeletal and cardiac muscle development) (table 8.5). ${ }^{104}$

Table 8.5

Embryonic genes

\begin{tabular}{lc}
\hline Genes & $\begin{array}{c}\text { Expresion compared } \\
\text { to control treatment }\end{array}$ \\
\hline KIF3B & 2.1 \\
Fit-1 & $>>50$ \\
Skimproto-oncogene & 5.0 \\
LKLF & 2.3 \\
NF-E2 & 2.2 \\
C-ErbA oncogene & -2.2 \\
MLC fetal isoform & -14.3 \\
\hline
\end{tabular}




\section{Cell turnover}

Table 8.6

Genes involved in cell turnover

\begin{tabular}{ll}
\hline Genes & $\begin{array}{l}\text { Expression compared } \\
\text { to control treatment }\end{array}$ \\
\hline B-Rat proto-oncogene & 3.1 \\
Ski-proto-oncogene & 5.0 \\
Etoposide induced p53 & 2.5 \\
ICE & 3.1 \\
IAF-1 & $>>50$ \\
EGR-1 & $>>50$ \\
CD14 & 5.5 \\
Prothymosin a & -6.3 \\
BFGF & -3.8 \\
Tob anti-proliferative & -7.7 \\
\hline
\end{tabular}

Anti-CD40L antibody treatment resulted in a different expression of genes involved in cell turnover. However, a clear pattern could not be defined (table 8.6). Expression of genes, known to stimulate DNA synthesis (B-raf proto-oncogene ${ }^{105}$, ski-proto-oncogene ${ }^{106}$ ) as well as apoptosis inducing genes (etoposide induced p53 response factor ${ }^{107}, I^{6} E^{66}, I R F^{108}$ and EGR-1 ${ }^{109}, C^{10} 14^{69}$ ) was increased after anti-CD4OL antibody treatment, whereas the expression of other genes that exert the same function, was decreased (prothymosin $\alpha^{110}$ and bFGF receptor ${ }^{111}$ (proliferation), and Tob-antiproliferative factor ${ }^{112}$ (inhibition cell cycle)).

\section{Others}

Table 8.7

\section{Other genes}

\begin{tabular}{lc}
\hline Genes & $\begin{array}{c}\text { Expression compared } \\
\text { to contiol treatment }\end{array}$ \\
\hline Stall 1 & 2.1 \\
Stat 3 & 2.3 \\
Stat 6 & $>>50$ \\
Pli3K & $>>50$ \\
Gem induced & 10.0 \\
Insulin receptor & $>>50$ \\
Serotonin receptor & $>>50$ \\
\hline
\end{tabular}

Lastly, genes that exert a wide variety of functions, such as signal transduction molecules and transcription factors, showed a differential expression pattern after anti-CD4OL antibody treatment (table 8.7). 


\subsubsection{Postulated mechanisms: Hypothesis}

From the preliminary MRNA and protein expression data, we derived the following hypothesis for the development of CD4OL inhibition induced stable plaque phenotype:

During atherogenesis, plaque cell types come into contact with a large variety of substances, such as chemokines, cytokines, MMPs and OxLDL, which induce changes in SMC and macrophage phenotype, contributing to the progression of atherosclerosis and destabilisation of the atherosclerotic lesion. ${ }^{3,18}$ SMCs switch from a contractile into a synthetic phenotype and gain a different subset of markers ${ }^{113}$, whereas macrophages ingest lipids and become macrophage derived foam cells, thereby gaining a different subset of phenotypical markers, like the scavenger receptor. ${ }^{47}$

Our preliminary differential expression data suggest that inhibition of the CD40CD4OL system induced downregulation of inflammatory pathways (table 8.1). Furthermore, a different subset of genes involved in differentiation in general, and especially genes involved in the phenotypic modulation of SMCs and macrophages was observed (table 8.3). We therefore hypothesize that inhibition of CD40-CD40L (in)directly modulates SMC and macrophage phenotype. In our hypothesis, the different macrophage and SMC phenotype might be more resistant to oxidative stress (table 8.2), will increase extracellular matrix deposition and decrease extracellular matrix degradation (table 8.4), and will induce the expression of genes involved in mesenchymal patterning (table 8.5), all features favorable for the development of a stable atherosclerotic plaque phenotype (fig. 8.1) ${ }^{18}$

A candidate factor, that is important in modulating SMC and macrophage phenotype, that also acts as a collagen-promoting factor, is TGF $\beta$. Interestingly, many genes that are differentially expressed after anti-CD4OL antibody treatment are positively correlated with the expression of TGF $\beta$. For example, EGR-1 induces the expression of TGF $\beta^{83}$, as well as NF-E2 ${ }^{114}$. Moreover, the ski-proto-oncogene interferes with TGFB signalling, and is able to inhibit the induction of TGF $\beta$ as part of a negative feedback mechanism ${ }^{115}$. Moreover, we also observed an increased protein expression of TGF $\beta$ in atherosclerotic lesions after CD4O-CD40L inhibition. ${ }^{27}$ The relation between the CD40-CD4OL system and TGF $\beta$ was also shown in rat cultured microglia, in which TGFB is able to downregulate CD40 expression. ${ }^{116}$ Therefore, we consider TGF $\beta$ as one of the key factors that modulate the development of the stable plaque phenotype atter CD40-CD40L inhibition.

To test the latter hypothesis, additional experiments need to be performed. For validation of the CDNA-expression array data, the experiment has to be repeated and RT-PCR analysis, RNA in situ hybridization, as well as immunohistochemistry and Western blotting, has to be performed. Intervention studies with candidate regulators in such model as the ApoE- $/$ - mice will reveal their in vivo imporlance. 

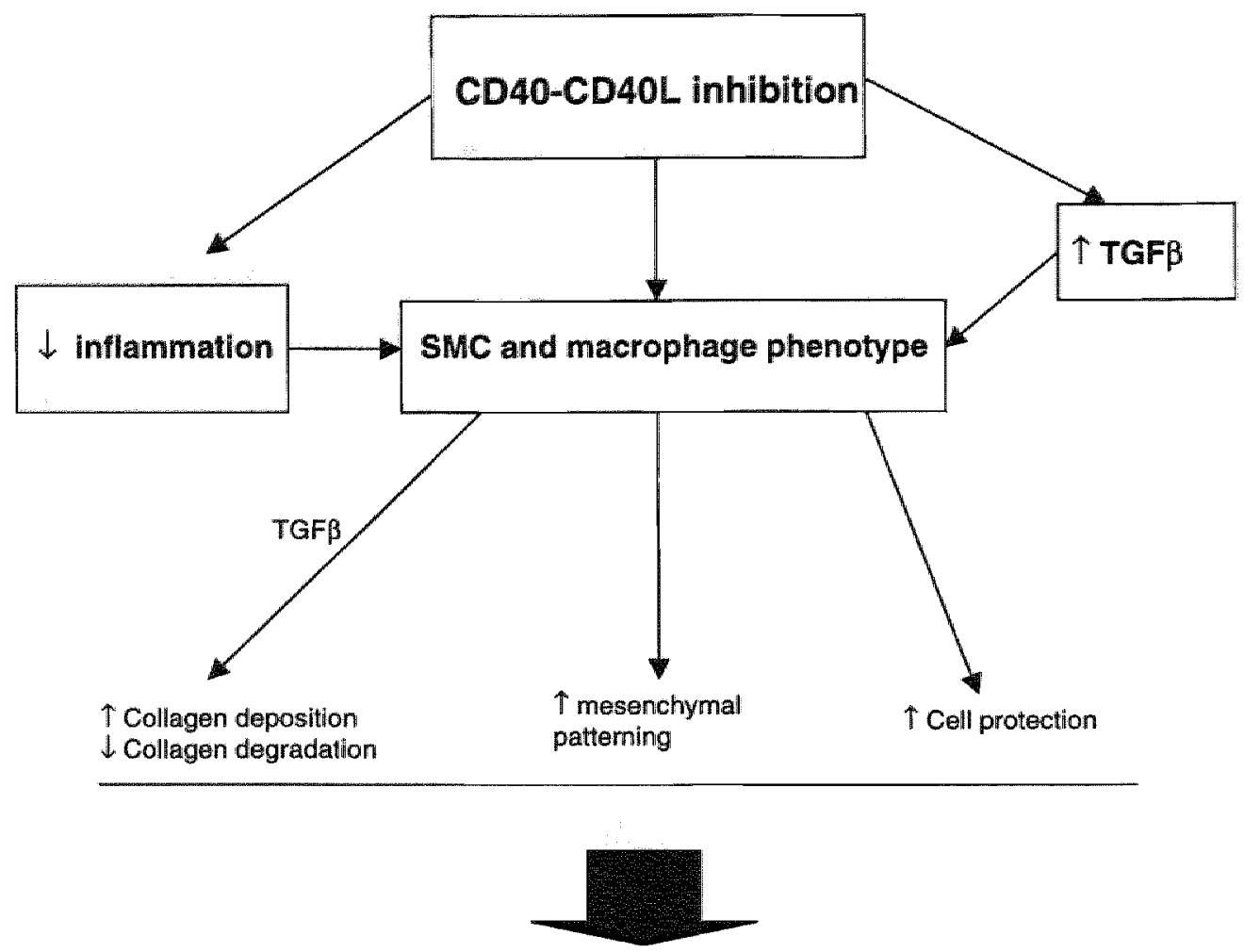

\section{Stable plaque phenotype}

Fig. 8.1

Postulated mechanisms responsible for the development of the CD4OL inhibition induced stable plaque phenotype.

\subsection{Limitations of the study}

The current data further elucidate the role of cell turnover, inflammation and the immune system in the pathogenesis atherosclerosis. Other factors that are important, especially genetic predisposition and the interplay between environmental influences and genetic background were not addressed. The majority of the conclusions are based upon data that were generated in mouse models of atherosclerosis and should be translated to clinical atherosclerosis with caution. Several differences between mouse models of atherosclerosis and human atherosclerosis need to be addressed. 
Although atherosclerosis in mice develops more slowly than restenosis, the atherosclerotic process in mice is still rapid compared to the development of the disease in man. This may obscure some aspects of (early) plaque progression relevant to the human situation.

lnward remodeling was not observed in our mouse models and this may be related to different flow and shear conditions in mice as compared to men. The mouse cardiovascular system can be characterized as a high flow system in small caliber vessels and it is unknown whether the same shear conditions as in the human vasculature apply. ${ }^{17}$ Furthermore, our morphologic observations were performed in the large vessels of the mouse arterial system and therefore may not be totally applicable to the human coronary vasculature, where plaque rupture and thrombosis accounts for the majority of atherosclerosis related mortality and morbidity. The heterogemeity of vascular function that is encountered when studying different human vascular beds was not addressed. ${ }^{118}$

Although striking observations with respect to plaque phenotype were made, caution should be made linking lesion morphology to plaque vulnerability. This is also reflected in human atherosclerosis, for example, endothelial abrasion on plaques that have several morphologic characteristics of a stable plaque phenotype may still lead to thrombosis. ${ }^{119}$

Other (functional) aspects, important in the pathogenesis of atherosclerosis, should be taken into account as well. A number of key physiologic parameters such as systolic blood pressure, heart-rate, endogenous t-PA activity, PAl-1 levels (chapter 1), that act in concert to accelerate the progression of atherosclerosis, were not determined.

\subsection{Anti-CD4OL antibody treatment: a future therapy for atherosclerosis?}

The current results corroborate the role of inflammation and immune activation in atherosclerosis. The contribution of cellular proliferation appears to be limited and therefore clinical application of anti-proliferative drugs seems more appropriate in the prevention of restenosis than to prevent cell turnover during early stages of atherogenesis.

The effect of inhibition of the CD40/CD40L system on plaque morphology would validate a clinical trial on patients presenting with thrombotic coronary syndromes appropriate. However, inhibition of this system might compromise the immune system of the patient. Therefore during clinical application of anti-CD4OL antibody for the stabilization of ruptured coronary plaques, monitoring of the immunesystem would be necessary. To overcome this problem, vascular-specific administration by gene transter may be needed.

Another approach to overcome the side effects of systemic CD40-CD40L inhibition, would be activation of the same cascade as CD40-CD4OL inhibition, but through another target protein (eg. TGF $\beta$ ). To identify such a therapeutic larget. further elucidation of the mechanism, responsible for the observed phenotype, is required. Therefore, validation of the cDNA-expression array results (paragraph 8.3), as well as additional experiments (ie micro-arrays, in vivo experiments) will be needed. 
The preiminary results from analysis of the cDNA expression array point to a role for TGFB in the development of a stable atherosclerotic plaque phenotype. Interestingly, inhibition of TGFB has been shown to promote atherogenesis in mice ${ }^{120}$, while the tamoxifen induced increase in TGFB, decreased plaque area in ApoE-1-mice. ${ }^{121}$ Furthermore, the protective effects of tamoxifen against cancer and cardiovascular morbidity in patients with breast cancer may be mediated through increases in serum TGFB levels. 122 Therefore, a strategy of augmenting TGFB levels in the arterial wall potentially may have a profound effect on atherogenesis.

\subsection{Concluding remarks}

The role of cell tumover in primary atherosclerosis remains questionable. Although our data show a peak in DNA-synthesis in early lesions ${ }^{17,19}$, and elevated levels of apoptosis in advanced atherosclerotic lesions ${ }^{17,19}$, the contribution of DNAsynthesis and apoptosis in lesion initiation and progression seems to be limited. This is reflected by the negative results obtained from intervention studies aimed at atering the rate of cell turnover, and from our own studies described in chapter 5,6 and 7 . In these studies, absence of Gas6, as well as inhibition of the CD40-CD4OL system ${ }^{26,27}$, induced a different plaque phenotype but neither DNA-synthesis nor apoptosis were affected. These results indicate that other mechanisms are more important in regulating the plaque phenotype.

Since more and mare studies showed a limited effect of cell turnover in atherosclerosis, the 'response to infury' hypothesis was modified. It is now stated that endothelial activation, and the consequent upregulation of inflammatory pathways and the immune system, rather than massive mechanical injury is important in atherosclerosis. ${ }^{18}$ Evidence for this hypothesis was obtained by the results of several intervention studies, aimed to intervene in inflammatory pathways (chapter 1, table 1.6). This is also reffected by the data in this thesis. Inhibition of the CD4D-CD4OL system, a key regulator of inflammation and the immune system resulted in the development of a collagen-rich, lipid-poor stable plaque phenolype. ${ }^{26,27}$ Although precise mechanisms are not known. preliminary results imply that, besides downregulation of inflarnmatory pathways, CD40-CD4OL inhibition might (in)directly cause phenotypic modulation of SMCs and macrophages. A key regulator, responsible for the phenotypic modulation and the development of the stable plaque phenotype, might be TGFB.

In conclusion, this thesis provides interesting new insights into the pathogenesis of atherosclerosis. It reveals that the importance of cell turnover in atherosclerosis may be limited, while inflammatory pathways and the immune system seems to play a major role in atherosclerosis. The CD40-CD4OL system is an interesting therapeutic target, since its inhibition results in the development of a lipid-poor; collagen-rich, stable plaque phenotype in mice. However, precise mechanisms, responsible for the development of this phenotype, and the exact role of CD40CD40L interactions in human atherosclerosis remain to be elucidated. 
1. Wirchow R: Celluar pathology as based upon physiological and pathological histology. Classics of medicine library. Birmingham, Alabama, 1858 .

2. Foss $R_{1}$ Glomset JA: Atherosclerosis and the arterial smooth muscle cell. Science $1973,180: 1332-1339$.

3. Ross R: The pathogenesis of atherosclerosis: a perspective for the 1990s. Nature 1993;362:801809.

4. Clowes, AW, Reidy MA, Clowes MM: Kinetics of cellular proliferation after arterial inifury. I. Smooth muscle growth in the absence of endothelium. Lab Imvest 1983;49:327-333.

5. Clowes AW, Clowes MM, Fingerle J, Reidy MA: Regulation of smooth muscle cell growth in injured artery. J Cardiovasc Phamacol 1989;14:S12-S15.

6. Jawien A. Bowen-Pope DF, Lindner V. Schwartz SM. Clowes AW: Platelet-derived growth factor promotes smooth muscle migration and intimal thickening in a rat model of balloon angioplasty. J Clin Invest 1992;89:507-511.

7. Neschis DG, Safford SD. Hanna AK. Fox JC. Golden MA: Antisense basic fibroblast growth factor gene transfer early intimal thickening in a rabbit femoral artery balloon injury model. I Vasc Surg 1998;27:126-134.

8. Daemen MJAP, Lombardi DM. Bosman FT, Schwartz SM: Angiotensin II induces smooth muscle cell proliferation in the normal and injured rat arterial wall. Circ Res 1991;68:450-456.

9. Ruef J, Meshel AS. Hu Z, Horaist C. Ballinger CA. Thompson LJ, Subbarao VD. Dumont JA, Patterson C: Flavoperidol inhibits smooth muscie cell proliferation in vitro and neointimal formation in vivo after carotid injury in the rat. Circulation 1999; 100:659-665.

10. Tanner FC, Boehm M. Akyurek LM, San H, Yang ZY, Tashiro J, Nabel GJ, Nabel EG: Differential effects of the cyclin-dependent kinase inhibitors p27, p21, and p16 on vascular smooth mucle cell proliferation. Circulation 2000;101:2022-2025.

11. Thomas WA, Lee KT, Kim DN: Cell population dynamics in atherogenesis: cell births and losses in intimal cell mass-derived lesions in the abdominal aorta of swine. Ann $N$ Y Acad Sci $1985: 454: 305-315$.

12. Rosenfeld ME, Ross $\mathrm{R}$ : Macrophage and smooth muscle cell proliferation in atherosclerotic lesions of WHHL and comparably hypercholesterolemic fat-fed rabbits. Arteriosclerosis $1990 ; 10: 680-687$

13. Rekhter MD, Gordon D: Active proliferation of different cell types "including lymphocytes, in human atherosclerotic plaques. Am J Pathol 1995;147:668-677.

14. Gordon D, Reidy MA, Benditt EP, Schwartz SM: Cell proliferation in human coronary arteries. Proc Natl Acad Sci US A 1990;87:4600-4604.

15. O'Brien ER, Alpers CE, Stewart DK, Ferguson M, Tran N, Gordon D, Benditt EP, Hinohara T. Simpson $\sqrt{ }$, Schwartz SM: Proliteration in primary and restenotic coronary atherectomy tissue. Implications for antiproliferative therapy. Circ Res 1993;73:223-231.

16. Brandl $\mathbb{R}$, Richter $T$. Haug $K$. Wiheim MG, Maurer PC. Nathrath W: Topographic analysis of proliferative activity in carotid endarterectomy specimens by immunocytochemical detection of the cell cyclerrelatted antigen Ki-67. Circulation 1997:96:3360-3368.

17. Lutgens E, de Muinck ED, Kitslaar PJEHM, Tordoir JHM, Wellens HJU, Daemen MJAP: Biphasic pattern of cell iurnover characterizes the progression from fatty streaks to ruptured human atherosclerotic plaques. Cardiovasc Res 1999;41:473-479.

18. Ross R: Atherosclerosis. An inflammatory disease. N Engl J Med 1999;340:115-126.

19. Lutgens E, Daemen M, Kockx M. Doevendans P. Hofker M. Havekes L. Wellens H, de Muinck E: Atherosclerosis in APOE*3 Leiden transgenic mice: from proliferative to atheromatous stage. Circulation 1999:99:276-283.

20. Orekhow AN, Kosykh VA, Repin VS, Smimov VN: Cell proliferation in normal and atherosclerotic aorta. Il. Autoradiographic observation on deoxyribonucleic acid synthesis in primary cell cullure. Lab lowest 1983:48:749-754.

21. Benditt EP. Benditt JM. Evidence for a monoclonal origin of human atherosclerotic plaques. Proc Natl ACad SCIUS A 1973;70:1753-1756.

22. Murry CE, Gipaya CT, Bartosek T, Benditt EP. Schwartz SM: Monoclonality of smooth muscle cells in human atherosclerosis. Am J Pathol 1997;151:697-706.

23. Schwartz SM, Majesky MW. Murry CE: The intima: development and monoclonal responses to 
miury. Atheroscherosis 1995:118:S125-\$140.

24. Chung IM, Schwartz SM. Mury CE: Clonal architecture of normal and atherosclerotic aorta. Am $J$ Pathol 1998; $152913-923$.

25. Schneider C. King RM. Phillipson L: Genes specifically expressed at growth arrest of mammalian celis. Cell 1988:54:787 793.

26. Lutgens E, Gorelk L. Daemen MAP, de Muinck ED. Grewal IS, Kotelianski VE, Flavell RA: Requirement for CD154 in the progression of atherosclerosis. Nat Med 1999;5:1313-1316.

27. Lutgens E, Cleutjens KBJM. Heeneman S, Koteliansky VE, Burkly LC, Daemen MIAP: Both early and delayed anti-CO4OL antibody treatment induces a stable plaque phenotype. Proc Natl Acad Sci USA $2000 ; 97: 7464-7469$

28. Andreeva ER. Pugach IM, Orekhov AN: Subendothelial smooth muscle cells of human aonta express macrophage antigen in situ and in vitro. Atherosclerosis 1997,135:19-27.

29. Bjorkerud $\mathrm{B}$ : Björkerud $\mathrm{S}$ : Contrary effects of lightly and strongly oxidized LDL with potent promotion of growth versus apoptosis on arterial smooth muscle cells, macrophages and fibroblasts. Arterioscler Thromb Vasc Biol 1996;16:416-424.

30. Clowes AW, Reidy MA, Clowes MM: Mechanisms of stenosis after arterial injury. Lab Invest $1983,49: 208-215$.

31. Han DKM, Haudenschild CCH, Hong MK. Tinkle BT, Leon MB, Liau G: Evidence for apoptosis in human atherogenesis and in a rat vascular injury model. Am w Pathol 1995; 147:267-277.

32. Kockx MM, De Meyer GR, Muhring J. Bult H. Bultinck J. Herman AG: Distribution of cell replication and apoptosis in atherosclerotic plaques of cholesterol-fed rabbits. Atherosclerosis $1996: 120: 115-124$

33. Geng YJ, Libby P: Evidence for apoptosis in advanced human atheroma. Colocalization with interleukin-1 beta-converting enzyme. Am J Pathol 1995; 147:251-266.

34. Isner JM, Kearney M. Bortman S, Passeri J: Apoptosis in human atherosclerosis and restenosis. Circulation 1995:91:2703-2711.

35. Kockx MM, Muhring $\Downarrow, K n a a p e n ~ M W M$ de Meyer GRY: RNA synthesis and splicing interferes with DNA in situ end labeling techniques used to detect apoptosis. Am J Pathol 1998;152:885888.

36. Kockx MM, de Meyer GRY, Muhring J, Jacob W. Bult H. Herman AG: Apoptosis and related proteins in different stages of human atherosclerotic plaques. Circulation 1998:98:2307-2315.

37. Kockx MM, Knaapen MW: The role of apoptosis in vascular disease. J Pathol 2000;190:267-280.

38. Kockx MM. Herman AG: Apoptosis in atherosclerosis: beneficial or detrimental? Cardiovasc Res $2000,45: 736-746$.

39. Bayes-Genis A, Conover CA. Schwartz RS: The insulin-like growth factor axis. A review of atherosclerosis and restenosis. Circ Res 2000;86:125-130.

40. Niebauer J, Schwarzacher SP. Hayase M, Wang B, Kernoff RS, Cooke JP, Yeung AC: Locall LArgenine delivery after balloon angioplasty reduces monocyte binding and induces apoptosis. Circulation 1999;100:1830-1835.

41. Igase M, Okura T. Kitami $Y$, Hiwada K. Apoptosis and Bcl-xs in the intumal thickening of ballooninjured carotid arteries. Chin Sci 1999,96:605-612.

42. Schneider DB, Vassalli G, Wen S, Driscoll RM, Sassani AB, De Young MB, Linnemann A, Virmani A. Dichek DA: Expression of Fas ligand in arteries of hypercholesterolemic rabbits accelerates atherosclerotic lesion formation. Arterioscler Thromb Vasc Biol 2000;20:298-308.

43. Mach F. Schonbeck U. Sukhova GK. Atkinson E, Libby P. Reduction of atherosclerosis in mice by inhibition of CD40 signaling. Nature 1998;394:200-203.

44. Schönbeck U, Sukhova GK, Shimizu K, Mach F. Libby P: Inhibition of CD40 signaling limits evolution of established atherosclerosis in mice. Proc Natl Acad Sci U S A 2000:97:7458-7463.

45. Libby P: Molecular bases of the acute coronary syndromes. Circulation 1995;91:2844-2850.

46. Phipps PP: Atherosclerosis: the emerging role of inflammation and the CD40-CD40 ligand system. Proc Natl Acad Soi U S A 2000;97:6930-6932

47. Schmitz G. Orso $E$. Rothe G. Klucken J: Scavenging signalling and adhesion coupling in macrophages: implications for atherogenesis. Curr Opin Lipidol 1997;8:287-300.

48. Wahl SM: Transforming growth factor beta: The good, the bad and the uglly. I Exp Med $1994 ; 180: 1587-1590$.

49. Schena $M$, Shalon $M$, Davis RW, Brown $O$ : Quantitative monitoring of gene expression patterns with a complementary DNA microarray. Science 1995;270:467-470. 
50. DeRisi $\rfloor_{1}$ Penland L, Brown PO. Bittner ML. Meltzer PS, Ray M, Chen Y. Su YA, Trent JM Use of a cDNA micro-array to analyse gene expression patterns in human cancer. Nat Gen $1996 ; 14: 457-460$.

51. Heller RA, Schena M, Chail A, Shalon D. Bedillon T, Gilmore J, Woolley DE, Davis RW: Discovery and analysis of inflammatory disease-related genes using CDNA microarreys. Proc Natl Acad SoI U S A 1997;94:2150-2155.

52. Stanton LW, Garrard Ld. Damm D, Garrick BL, Lam A, Kapoun AM, Zheng Q. Protter AA. Schreiner GF. White RT: Altered patterns of gene expression in response to myocardial infarction. Circ Pes 2000;86:939-945.

53. Terkeltaub R, Boisvert WA, Curtiss LK: Chemokines and atherosclerosis. Curr Opin Lipid 1998;9:397-405.

54. Cardier JE: Effects of megakaryocyte growth and development factor (thrombopoietin) on liver endothelial cells in vitro. Microvasc Res 1999;58:108 113.

55. Ye J, Cippitelli M. Dorman L, Ortaldo JR, Young HA The nuclear factor Y 11 suppresses the human gamma interferon promotor through two mechanisms: inhibition of A.PI binding and activation of a silencer element. Mol Cell Biol 1996;16:4744-4753.

56. Notarangelo LD. Villa A, Schwarz K: RAG and RAG defects. Curr Op immunol 1999;11:435-442.

57. Fugmann SD, Lee Al, Shockett PE, Villey IU, Schatz DG: The RAG proteins and V[DJJ recombination: complexes, ends, and transposition. Annu Rev Immunol 2000:18:495-527.

58. Deussing J, Roth W. Sattig P, Peters C. Ploegh HL, Villadangos JA: Cathepsins B and D are dispensable for major histocompatibility complex class 11 mediated antigen presentation. Proc Nall Acad Sci U S A 1998;95:4516-4521.

59. Baxevanis CN, Gritzapis AD, Spanakos $G$, Tsitsilonis OE, Papamichail M: Induction of tumourspecific T-lymphocyte responses in vivo by prothymosin alpha. Cancer. Immunol. Immunother. $1995: 40: 410-418$

60. Baxevanis CN, Frillingos S, Seferiadis K, Reclos GJ, Arsenis $P_{n}$ Katsiyiannis A Anastasopoulos E. Tsolas $\mathrm{O}$. Papamichail M: Enhancement of human T-lymphocyte function by prothymosin alpha: increased production of interleukin 2 and expression of interleukin 2 receptors in normal human peripheral blood T.lymphocytes. Immunopharmacol immunotoxicol 1990; 12:595-6.17.

61. Kuo CT, Leiden JM: Transcriptional regulation of Tlymphocyte development and function. Annu Revimmunol 1999;17:149-187.

62. Masteller EL, Chuang E, Mullen AC, Reiner SL, Thompson CB: Structural analysis of CTLA-4 function in vivo. $J$ Immunol 2000;164:5319-5323

63. Gacient RA, Patterson PH: Leukemia inhibitory factor, interleukin 6, and other cytokines using the gp 130 transducing receptor: roles in inflammation and injury. Stem Celfs 1999;17:127-137.

64. Stanley ER, Guilbert LJ, Tushinski RJ, Bartelmez SH: CSF-1-A mononuclear phagocyte lineage specific hemopoietic growth factor. J CeN Biochem 1983;21:151-159.

65. Ziegler-Heitbrock HWL. Ulevitch RJ: CD 14 . Cell surface receptor and differentiation marker Immunol Today 1993:14:121-125.

66. Dinarello CA: Interleukin-1 beta, interleukin-18, and the interleukin-1 beta conventing enzyme Ann N Y Acad Sci 1998;856:1-11.

67. Hernandez-Presa MA. Bustos C, Ortego M. Tunon J, Ortega L. Egido J: ACE inhibitor quinapril reduces the arterial expression of NFkB dependent proinflammatory factors, but not of collagenl in a rabbit model of atherosclerosis. Am I Pathol 1998:155:1825-1837.

68. Hobart M. Ramassar $V$. Goes N, Umson J. Halloran PF: IFN regulatory factor 1 plays a central role in the regulation of the expression of classl and 11 MHC genes in vivo. J Immunal $1997,158: 4260-4269$.

69. Gregory CD: Non-inflammatory, anti-inflammatory CD14 responses: CD14 in apoptosis. Chem immunol 2000:74:122-140.

70. David ML. Hanna AK, Tomaszewski JE, Karikok A, Barnathan ES, Golden MA: Thermal preconditioning before rat anterial balloon injury: limitation of injury and sustained reduction of intimal thickening. Anterioscler Thromb Vasc Biol 1998;18:120-126.

71. Ducret C. Maria SM. Dierich A. Wasylyk B: The Net repressor is regulated by nuclear export in response to anisomysin, UV, and heat shock. Mol Cell Biol 1999; 19:7076-7087.

72. Brigelius-Flohe R: Tissue specific functions of individual gluthathione peroxidases. Free Rad Biol Med 1999;27:951-965.

73. Favaloro B. Tamburro A, Trotino MA, Bologna L. Rotilio D. Heipieper HJ: Modulation of the 
gluthathione S-transferase in Ochrobactrum anthropi: function of xenobiotic substrates and other forms of stress. Biochem J 2000; $346: 553-559$.

74. Nguyen T. Huarig MC. Pickett CB: Transcriptional regulation of the anti-oxidant responsive element. Activation by Nri2 and repression by MapK. I Biol Chem 2000:275:15466-15473.

75. van der Spek PJ, Visser CE, Hanaoka F. Smit B. Hagemeijer A Bootsma D. Hoeijmakers JH: Cloning, comperative mapping, and FNA expression of the mouse homologues of the Saccharomyces cerevisiae nucleotide excision repair gene RAD23. Genomics 1996:31:20-27.

76. Kohda $T$, Kondo $K$, Oishi M: Cellular HSP90 (HSP86) MRNA level and in vitro differentiation of mouse embryonal carcinoma (F9) cells. FEBS letters 1991;290:107-110.

77. Boguski MS, McCormick F: Proteins regulating Ras and its relatives. Nature 1993:366:643-654.

78. Sayer MS, Tilbrook PA, Spadaccini A, Ingley E, Sarna MK, Williams JH, Andrews NC, Klinken SP". Ectopic expression of transcription factor NF-E2 alters the phenotype of erythroid and monoblastic cells. J Biol Chem 2000, 275:25292-8

79. Tumer $J$ Crossley M: Basic kruppel like factor functions within a network of interacting hematopoletic transcription factors. Int J Biochem Cell Biol 1999:31:1169-1174.

80. Aikawa M, Sakomura $Y$, Ueda M. Kimura K, Manabe I, Ishiwata S, Komiyama N, Yamaguchi $H$, Yazaki $Y$. Nagai $R$ : Redifferentiation of smooth muscle cells after coronary angioplasty determined via myosin heavy chailn expression. Circulation 1997;96:82-90.

81. Ambrose MR, Bottazzi ME, Goodenow MM: Expression of the ski-proto-oncogene during cell cycle arrest and myogenic differentiation. DNA Cell Biol 1995;14:701-714.

82. Hautmann MB. Madsen CS, Owens GK: A transforming growth factor beta (TGFbeta) controf element drives TGFbeta-induced simulation of smooth muscle allpha actin gene expression in concert with two CarG elements. J Biol Chem 1997;272: 10948-10956.

83. Liu C, Yao J, de Belle I. Huang RP, Adamson E. Mercola D: The transcription factor EGR-1 suppresses transformation of human fibrosarcoma HT1080 cells by coordinated induction of transforming growth lactor- $\beta 1$, fibronectin, and plasminogen activator inhibitor- 1 . I Biol Chem $1999: 274: 4400-4411$

84. Saltis J. Thomas AC, Agrotis A. Campbell JH. Campbell GR, Bobik A: Expression of growth factor receptors in arterial smooth muscle cells. Dependency on cell phenotype and serum lactors. Atherosclerosis 1995:118:77-87.

85. Engelse MA, Neele JM, van Achterberg TAE, van Aken BE, van Schaik PHN, Pannekoek $H$, de Vries CuM: Human activin- $A$ is expressed in the atherosclerotic lesion and promotes the contractile phenotype of smooth muscle cells. Circ Res 1999;85:931-939.

86. Hershey JC, Hautmann M, Thompson MM, Rothblum LI, Haystead TAJ, Owens GK: Angiotensin Ilinduced hypertrophy of rat vascular smooth muscle is associated with increased I8S IRNA synthesis and phosphorylation of the rRNA transcription factor, upstream binding factor. I Biof Chern 1995:270:25096-25101.

87. Hirano T, Ishihara K. Hibi M: Roles of STAT3 in medliating the cell growth, differentiation and surviva! signals relayed through the IL-6 family of cytokine receptors. Oncogene 2000; 19:25482556.

88. Akuzawa $N$, Kurabayashi M, Ohyama $Y$, Aral M. Nagai R: Zino finger transcription factor EGR-1 activates Fit-1 gene expression in THP-1 cells on induction for macrophage differentiation. Arterioscler Thomb Vasc Bial 2000:20:377-384.

89. LI W. Yuan XM, Olsson AG, Brunk UT: Uptake of oxidized LDL by macrophages results in partial Iysosomal enzyme inactivation and relocation. Anterioscler Thromb Vasc Biol 1998;18:177-184.

90. Fester $U$, Champion $C$. Kain HL: Transdifferentiation of human monocytes into fibroblast like cells in vitro. Ger J Ophtalmol 1995:4:182-187.

91. Schulick AH, Taylor A., Zuo W, Qiu C., Dong G. Woodward RN, Agah R, Foberts AB, Virmani R, Dichek DA: Overexpression of transtoming growth factor b1 in arterial endothelium causes hyperplasia, apoptosis and cartilaginous metaplasia. Proc Nabl Acad Sci U S A 1998,95.6983. 6983

92. Drees B. Friederich E. Fradelizi J, Louvard D, Beckerle MC, Golsteyn R: Characterization of the interaction between zyxin and members of the EnaNASP (vasodilator stimulated phosphoprotein) family of proteins. I Biol Chem 2000;275: 22503-22511.

93. Gabbiani G, Schmid E. Winter S, Chaponnier C, Chastonay C. Vanderkerckhove J, Weber K, Franke W: Vascular smooth muscle cells differ from other smooth muscle cells: Predominance of vimentin tilaments and specific alpha-type actin. Proc Natl Acad Soi U S A 1981;78:298-302. 
94. Glukhova MA, Shekhonin EV, Kruth $H$, Koteliansky VE: Expression of cytokeratin 8 in human aortic smooth muscle cells. Am J Physiol 1991:261:72-77.

95. Amento EP. Eshani N. Palmer H, Libby P: Cytokines and growth factors positively and negaively regulate interstitial collagen gene expression in human vascular smooth muscle cells. Anterioscler Thromb 1991:11:1223-1230.

96. Rossil P, Karsenty G, Roberts AB, Roche NS, Sporn MB, de Crombrugghe B: A nuclear factor 1 binding site mediates the transcriptional activation of a type I collagen promotor by transforming growth factor-beta. Cell 1988;52:405-414

97. van Krimpen C. Schoemaker RG. Cleutjens JP. Smits JF. Struyker-Boudier HA, Bosman FT, Daemen $\mathrm{MJ}$ : Angiotensin | converting enzyme inhibitors and cardiac remodeling. Basic Res Cardiol 1991;86 Suppl 1:149-155.

98. Tyagi SC: Preoteinases and extracellular matrix turnover. Mol Cell Biochem 1997;168:1-12.

99. Knox JB, Sukhova GK, Whittemore AD, Libby P: Evidence for altered balance between matrix metalloproteinases and their inhibitors in human aortic diseases. Circulation 1997:95:205-212.

100. Takeda S, Yonekawa $Y$. Tanaka $Y$. Okada $Y$. Nonaka S. Hirokawa N: Left-right asymmetry and kinesis superfamily protein KIF3A: New insights in determination of laterality and mesoderm induction by kif3A- - mice analysis. I Cell Biol 1999; 145:825-836.

101. Fong GH, Zhang L, Bryce DM. Peng J: Increased hemangioblast commitment, not vascular disorglanisation is the primary defect in fft- 1 knock-out mice. Development 1999; $126: 3015-3025$.

102. Kuo CT, Veselits ML, Barton KP, Lu MM, Clendenin C. Leiden JM: The LKLF transcription factor is required for normal tunica media formation and blood vessel stabilization during murine embryogenesis. Genes Dev 1997;11:2996-3006.

103. Orkin SH: Embryonic stem cells and transgenic mice in the study of hematopoiesis. Int I Dev Biol 1998;42:927-934.

104. Lyons GE, Ontell $M$, Cox $R$. Sassoon $D$. Buckingham $M$ : The expression of myosin genes in developing skeletal muscle in the mouse embryo. J Cell Biol 1990;111:1465-1476.

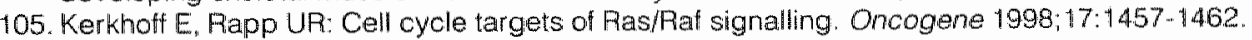

106. Sutrave $\mathrm{P}$. Hughes SH: The ski oncogene. Oncogene 1991;6:353-356.

107. Lehar SM, Nacht M. Jacks T, Vater CA, Chittenden T. Guild BC: Identification and cloning of El24, a gene induced by p53 in etoposide-lreated cells. Oncogene 1996:12:1181-1187.

108. Kano A. Harayuma T, Akaike T. Watanabe Y: IRF. 1 is an essential marker in IFN gamma induced cell cycle arrest and apoptosis of primary cultured hepatocytes. Blochem Biophys Res Commun $1999 ; 257: 672-677$.

109. Pang.$J H$. Chau LY: Copper induced apoptosis and immediate early gene expression in macrophages. Atherosclerosis 1999; 146:45-52.

110. Segade F, Gomez-Marquez J: Prothymosin alpha. Int J Biachem Cell Biol 1999;31:1243-1248.

111. Lindner V. Olson NE, Clowes AW, Reidy MA: Inhibition of smooth muscle cell proliferation in injured rat arteries. Interaction of heparin with basic fibroblast growth factor. If Clin invest 1992:90:2044-2049.

112. Guehenneux F. Duret L, Callanan MB. Bouhas R. Hayette S, Berthet C, Samarut C. Rimokh R. Birot AM, Wang Q. Magaud JP. Foualt JP: Cloning of the mouse BTG3 gene and definition of a new gene family (the BTG family) involved in the megative contral of the cell cycle. Lewkemia $1997,11: 370-375$.

113. Orlandi A, Ehrlich HP, Ropraz P. Spagnoli LG, Gabbiani $G$ : Rat aortic smooth muscle cells isolated from different layers and at different times after endothelial denudation shows distinct biological teatures in vitro. Arterioscler Thromb 1994:14:982-989.

114. MacLelan WR, Lee WT. Schwartz RJ. Schneider MD: Transforming growth factor-beta response elements of the skeletal alpha-actin gene. Combinatorial action of serum response factor, $Y Y 1$. and the SV40 enhancer-binding. TEF-1. J Biol Chem 1994;269:16754-16760.

115. Xu W. Angelis K. Danielpour D, Haddad MM. Bischof O, Campisi J. Stavnezer E. Medrano EE: Ski acts as a co-repressor with Smad2 and Smad3 to regulate the response to type $b$ transforming growth factor. Proc Natl Acad Sci U S.A. 2000;97:5924-5929.

116. We: $R$, Jonakait GM: Neutrophins and the anti-inflammatory agents interteukin-4 (IL-4), IL 10, IL 11 and transforming growth factor- $\beta 1$ (TGF- $\beta 1$ ) down-regulate $T$ cell co stimulatory molecules $B 7$ and CD40 on cultured rat microglia. I Newrommunol 1999:95:8-18.

117. Yang Y. Powell-Braxton L, Ogaoawara AK, Dybdal N. Bunting S, Ohneda O, Jin H. Hypertension and endothelial dysfunction in apolipoprotein $E$ knockout mice. Arterioscl Thromb Vasc Biol 
$1999: 19: 2762-2768$

118. Guyton Hall, Texbook of medical physiology. $9^{\text {in }}$ edition, Saunders 1996, 171-179.

119. Vimani R, Kolodgie FD. Burke AP. Farb A. Schwartz. SM. Lessons from sudden cononary death: a comprehensive morphological classification scheme for atherosclerotic lesions. Arterioscler Thromb Vasc Biol 2000 May;20:1262.75

120. Grainger DJ, Kemp PR, Liu AC, Lawn RM, Metcalfe JC. Activation of transforming groth factor-B is inhibited in transgenic apoliporotein (a) mice. Nature 1994;370:460 462 .

121. Reckless J, Metcalfe JC. Grainger DJ. Tamoxifen decreases cholesterol sevenfold and abolishes lipid lesion development in apolipoprotein E knockoul mice. Circulation 1997;95:15421548.

122. McDonald CC. Alexarder FE, Whyte BW. Forrest AP. Stewart HJ. Cardiac and vascular morbidity in women receiving adjuvant tamoxiten for breasit cancer in a randomised trial. BMJ $1995,311: 977-980$. 


\title{
Summary
}

\section{Samenvatting}

\author{
Dankwoord
}

Curriculum vitae 

Summary

Atherosclerosis is the leading cause of morbidity, disability and mortality in the developed world. Despite our familiarity with the clinical symptoms of the disease, its pathogenesis remains poorly understood. Two mechanisms that are considered to play a major role in atherosclerosis are changes in cell turnover (DNA-synthesis and apoptosis) and chronic inflammation.

In the present thesis we focused on these two mechanisms. In the first part we hypothesized that the level, distribution pattern and phenotype of DNA-synthesizing and apoptotic cells change during the diverse stages of atherosclerosis. In addition. we expected that Gas6 deficiency (a gene important in cell survival) would suppress DNA-synthesis and promote apoptosis, thereby resulting in smaller artherosclerotic plaques. The second part of this thesis focuses on the role of inflammation in lesion initiation and progression. Although many papers report an important role for the diverse inflammatory parameters in atherosclerosis, a key regulator of inflammation in atherogenesis is not known. We hypothesize that CD40CD40L interactions, interactions important in immune- and inflammatory responses, play a key role in atherosclerosis. Therefore, we expected that inhibition of CD40CD4OL interactions would inhibit lesion initiation and progression.

In chapters 2 and 4, we characterized the initiation and progression of atherosclerotic lesions, as well as the effects of atherosclerosis on the entire vascular wall in two mouse models of atherosclerosis. The first part of chapter 2 describes the age and diet dependent progression of atherosclerosis in the ApoE*3Leiden mouse. We report that $A p o E^{\star} 3$ Leiden mice show a cranio-caudal lesion progression. Atherosclerotic lesions range from type I (a few macrophage derived foam cells) to type $V$ (lesions containing a lipid core and a fibrous cap). Immunohistochemistry revealed the presence of macrophages, SMCs, endothelial cells and T-lymphocytes in these lesions. Ruptured plaques (type VI), or plaques containing intra-plaque hemorrhage were however not observed.

In chapter 4, we investigated the response of the vascular wall (vascular remodeling) to atherosclerotic lesion progression in ApoE*3Leiden mice and ApoE-1-mice. In both mouse models, the carotid arteries, thoracic and abdominal aorta show compensatory enlargement in response to plaque progression. Enlargement was predominantly observed in advanced type $\mathbb{V}$ and $V$ lesions, most prominently in ApoE-/- mice. Despite the presence of compensatory enlargement, 
lumen diameter decreased and significant stenosis ( $>70 \%$ ) developed, but only in the carotid arteries. Constrictive remodeling, as well as ischemic organ damage was not observed.

In chapters 2 and 3 , we describe the level, distribution pattern and phenotype of DNA-synthesizing and apoptotic cells in atherosclerosis. Chapter 2 describes these phenomena in ApoE*3Leiden mice. In these mice. DNA-synthesis is highest in early type II lesions. Most DNA-synthesizing cells were located in the media. When atherosclerotic lesions progressed to type III-V lesions, DNA-synthesis shifted to the shoulder region, and its level decreased. Apoptosis was anly observed in advanced atherosclerotic lesions. Levels were low, and apoptotic cells were predominantly observed in the lipid core and regions adjacent to the lipid core. In all lesion types, both DNA-synthesis and apoptosis were mostly confined to the macrophage.

Chapter 3 describes the same parameters in human atherosclerosis. Also in human atherosclerosis. DNA-synthesis peaked in early type II lesions to decrease in type $V$ lesions. Interestingly, a second peak in DNA-synthesis was observed in type $\mathrm{Vl}$ lesions (ruptured plaques). DNA-synthesis was mostly confined to the macrophage or, in type V/ lesions, to macrophages and T-lymphocytes. As in mice, apoptosis was elevated only in advanced lesions in the lipid core or in regions adjacent to the lipid core. Most apoptotic cells were macrophages, although a significant amount were SMCs in the fibrous cap.

In conclusion, DNA-synthesis is an early phenomenon, whereas apoptosis is a late phenomenon of atherosclerosis. Furthermore, cell turnover is mostly confined to the macrophage.

In chapter 5, we describe the effect of deficiency of Gas6 on atherosclerosis. Gas6 is known as a survival factor, which inhibits apoptosis and stimulates DNA-synthesis in serum starved fibroblasts. Although we expected to find smaller lesions due to decreased levels of DNA-synthesis and elevated leveis of apoptosis, none of this was true. Interestingly, Gas6-/-/ApoE-/- mice developed a differently organized atherosclerotic plaque phenotype. These atherosclerotic lesions consisted of increased amounts of collagen and SMCs. However, compared to ApoE-/- mice, both SMCs and collagen fibers of Gas6-/-/ApoE-1- mice were distributed throughout the entire lesion. Furthermore, lesions of Gas6-/-/ApoE-1- mice were composed of multiple lipid cores. However, the most remarkable finding of this study was the development of intra-plaque hemorrhage in Gas6 deficient mice. Intra-plaque bleeding, associated with iron deposition and fibrin formation was observed in $>50 \%$ of the advanced lesions. 
The second part of this thesis focuses on the role of inflammation in atherosclerosis. especially on the role of the CD40-CD40L system. In chapter 6, we report that deficiency of the CD4OL gene in ApoE- $/$ mice results in a 5.5-fold decrease in plaque area. Furthermore, deficiency of CD4OL caused the development af a lipidpoor, collagen- and SMC rich plaque phenotype, with a decreased T-lymphocyte content, features of a stable atherosclerotic plaque phenotype. In a follow-up study. described in chapter 7, we obtained similar results using a pharmacological approach. Although we did not observe a decrease in plaque area, both early and delayed treatment with an anti-CD4OL antibody resulted in the same lipid-poor, collagen-rich, stable atherosclerotic plaque phenotype. Interestingly, anti-CD $40 \mathrm{~L}$ antibody treatment induced upregulation of TGF $\beta$.

In chapter 8 , the findings of this thesis are discussed. The first part of chapter 8 discusses the importance of DNA-synthesis and apoptosis on plaque progression and plaque phenotype. The second part discusses the role of inflammation, and the role of the CD40-CD40L system in particular in atherosclerosis. Furthermore, several mechanisms, responsible for the CD4OL inhibition induced stable plaque phenotype are postulated.

In conclusion, the role of cell turnover in primary atherosclerosis remains questionable. Although our data show an interesting pattern of cell turnover during atherogenesis, our intervention studies (both gas6 and CD4OL inhibition) reveal that the contribution of cell turnover in lesion initiation and progression is limited. On the other hand, this thesis confirms the important role of inflammation (and especially the CD40-CD40L interactions) on plaque progression and phenotype. The CD40. CD4OL system is an interesting therapeutic target, since its inhibition results in the development of a stable atherosclerotic plaque phenotype. However, precise mechanisms, responsible for the development of this phenotype still remain to be elucidated. 

Samenvatting

Atherosclerose (aderverkalking) is een systemische aandoening van de grote slagaders die ieder mens in meer of mindere mate treft. In de Westerse maatschappij zijn de gevolgen van atherosclerose doodsoorzaak nº . Klinische complicaties van atherosclerose omvatten $0 . a$. het myocardinfarct, herseninfarct en klachten van perifeer arterieel vaatlijden. Ondanks de klinische bekendheid met de gevolgen van atherosclerose, is de pathogenese van atherosclerose nog altijd slecht begrepen. Twee mechanismen waarvan men denkt dat deze een belangrijke rol spelen in de ontwikkeling en progressie van atherosclerose zijn "cell turnover" (DNA-synthese en apoptose) en chronische ontstekingsactiviteit.

In dit proefschrift zijn deze mechanismen verder onderzocht. In het eerste deel van dit proefschrift is de hypothese dat "het niveau, het verdelingspatroon en het fenotype van DNA-synthetiserende en apoptotische cellen verandert in de verschillende stadia van atherosclerose' in zowel muizen als mensen getoetst. Verder worden de effecten van een genetische interventie met Gas6, een gen dat een belangrijke rol speelt bij cel overleving beschreven. In deze studie haddien we verwacht dat afwezigheid van Gas6 zou leiden to een verminderde DNA-synthese en toegenomen apoptose, waarbij atherosclerose zou afnemen. Het tweede deel van dit proefschrift beschrijft de effecten van ontsteking in atherosclerose. Hoewel de belangrijke rol van chronische ontsteking in atherosclerose in vele artikelen beschreven wordt, zijn belangrijke regulatoren van de ontstekingscascade in atherosclerose nog grotendeels onbekend. In dit proefschrift hebben we de hypothese opgesteld dat CD40-CD4OL interacties, een systeem bekend van zijn rol in het immuunsysteem, een sleutelrol spelen in atherosclerose. Daarom verwachtten we dat remming van $\mathrm{CD} 4 \mathrm{OL}$ zou resulteren in een vermindering van atherosclerose.

In hoofdstuk 2 en 4 worden plaque initiatie en progressie, alismede de effecten van atheroscierose op de gehele vaatwand beschreven in 2 veelgebrukte muizenmodellen van atherosclerose. Het eerste deel van hoofdstuk 2 beschrijt de leeftijds- en dieet- afhankelijke progressie van atherosclerose in de ApoE*3Leiden muis. We laten zien dat ApoE*3Leiden muizen een cranio-caudale progressie van atherosclerose vertonen. Atherosclerotische plaques varieerden van vype I lesies (enkele schuimcellen) tot type $V$ lesies (met een necrotische kern en een fibreuze kap). Immunolabeling liet zien dat deze plaques waren opgebouwd uit macrofagen. 
gladde spiercellen, endotheelcellen en T-lymfocyten. Plaque-rupturen, of intraplaque bloedingen werden echter niet waargenomen.

In hoofdstuk 4 beschrijven we de effecten van atherosclerose op de gehele vaatwand (remodelering) in ApoE*3Leiden muizen en ApoE-l- muizen. In beide modellen laten de carotiden, thoracale en abdominale aorta compensatoire vergroting zien als reactie op plaque ontwikkeling en progressie. Dit was met name het geval in gevorderde type IV en $V$ lesies van ApoE-/- muizen. Ondanks het ontwikkelen van compensatoire vergroting, nam de luminale diameter af en ontstonden er stenoses van meer dan $70 \%$ in de carotiden. Echter, vasculaire constrictie, noch ischemische schade werden waargenomen.

In hoofdstuk 2 en 3 beschrijven we de hoeveelheid, verdeling en het fenotype van DNA-synthetiserende en apoptotische cellen in de diverse stadia van atherosclerose. In hoofdstuk 2 worden deze parameters beschreven in de ApoE*3Leiden muis. In deze muizen werd een DNA-synthese piek waargenomen in vroege type II lesies (fatty streaks), waarbij de meeste DNA-synthetiserende cellen in de media waren gelegen. Vanaf de ontwikkeling van type I!I lesies verschoof de DNA-synthese naar het schoudergebied van de plaque, en daalde de hoeveelheid. Apoptose daarentegen werd alleen in de late lesies gezien. De hoeveelheid apoptotische cellen was laag, en deze cellen werden voornamelijk gezien in de necrotische kern en zijn aangrenzende gebieden. In alle typen plaques waren zowel DNA-synthese als apoptose voornamelijk beperkt tot de macrofaag.

Hoofdstuk 3 beschrijt dezelfde fenomenen in humane atherosclerose. Ook in humane atherosclerotische lesies werd een DNA-synthese piek waargenomen in type II lesies. Verder werd er een tweede piek in DNA-synthese gezien in type VI lesies (geruptureerde plaques). DNA-synthetiserende cellen waren m.n. macrofagen en, in de geruptureerde plaques ook T-lymfocyten. Net als in muizenplaques was apoptose alleen verhoogd in vergevorderde plaques. Het grootste gedeelte apoptotische cellen was van macrofaag origine en was gelegen in de necrotische kern. Echter, een aanzienlijk deel van de apoptotische cellen waren gladde spiercellen in de fibreuze kap.

In hoofdstuk 5 worden de effecten van Gas6-deficiëntie in atherosclerose beschreven. Gas6 is een 'survival factor' die apoptose remt, en DNA-synthese stimuleert. We hadden daarom verwacht dat gas6 deficiëntie in een atherosclerotisch muizenmodel zou leiden tot kleinere atherosclerotische plaques. Echter, niets bleek minder waar. Gas6-/-/ApoE-/- muizen hadden een vergelijkbaar 
DNA-synthese en apoptose patroon, maar ontwikkelden een anders georganiseerde plaque. Plaques van Gas6-/ApoE-/- muizen bevatten meer gladde spiercellen. en meer collageen. Echter, gladde spiercellen waren door de gehele atherosclerotische plaque verspreid, en er werden jongere vormen van collageen waargenomen. Verder toonden de Gas6-1-/ApoE-I- muizen meerdere necrotische gebieden per lesie. Echter, de meest opmerkelijke bevinding van deze studie was het ontstaan van intra-plaque bloedingen in de Gas6-//ApoE-/- muizen. Deze intraplaque bloedingen waren geassocieerd met fibrine-formatie en ijzerdepositie, en werden in $>50 \%$ van de vergevorderde lesies gevonden.

Het tweede deel van dit proefschrift beschrijft de rol van ontsteking in de atherogenese, met speciale aandacht voor het CD4O-CD4OL systeem. In hoofdstuk 6 beschriven we dat deficientie van het CD4OL gen in ApoE- $/$ - muizen resulteert in een 5.5-voudinge afname van plaque oppervlak. Niet alleen was het plaque oppervlak afgenomen, ook vertoonden deze plaques kenmerken van een stabieler plaque fenotype. Deze plaques hadden o.a. een kleine necrotische kern, en bevatten veel collageen en gladde spiercellen. In een farmacologische follow-up studie, beschreven in hoofdstuk 7 , verkregen we soortgelijke resultaten. Alhoewel we geen afname van het plaque oppervlak zagen, resulteerde vroege en late antiCD4OL antilichaam behandeling in hetzelfde lipide-arme, collageen-en gladde spiercel-rijke atherosclerotische plaque fenotype. Verder vertoonden deze lesies een verhoogde expressie van TGFB.

In hoofdstuk 8 worden de bevindingen van dit proefschrift bediscussieerd. In het eerste deel wordt het belang van DNA-synthese en apoptose beschreven, terwijl het tweede deel zich richt op beschrijving van een eventueel toekomstige rol van antiCD4OL antilichaam behandeling in de toekomst. verder wordt over het mechanisme nagedacht, aan de hand van preliminaire resultaten verkregen met een CDNA expressie array.

Concluderend: of DNA-synthese en apoptose een belangrijke rol spelen in atherosclerose blijt nog maar de vraag. Hoewel onze data een interessant patroon van DNA-synthese en apoptose laten zien, laten onze interventiestudies (zowel gas6 als CD4OL inhibitie), slechts een beperkte rol voor DNA-synthese en apoptose in de initiatie en progressie van atherosclerose zien. Inflammatie (en met name het CD40CD40L systeem) blijkt echter een veel grotere rol to spelen in piaque progressie en fenotype. Aangezien het CD4O-CD4OL systeem resulteert in de ontwikkeling van een 
stabiel atherosclerotisch plaque fenotype, is dit systeem potentieel aantrekkelijk voor therapeutische doeleinden. Echter, het exacte mechanisme dat verantwoordelijk is voor de ontwikkeling van het stabiele plaque fenotype na CD40L inhibitie zal nog opgehelderd moeten worden. 
Na al deze wetenschappelijke uiteenzettingen, loopt dit proefschrift dan toch ten einde. Promoveren is meer dam alleen maar proefjes doen, en de weg van student naar promovendus kent naast veel plezier, ook vele hindernissen. Het resultaat mag er zijn: binnenkort is het dr. E. Lutgens!

De afgelopen jaren zijn voor mij erg belangrijk geweest. De studie geneeskunde, op kamers wonen, student-assistent, student-AlO, co-schappen, relatie, projecten binnenhalen, promoveren, de eed van Hippocrates afleggen, en vanaf mei 2001 : post-doc. Het afleggen van dit traject heb ik gelukkig niet alleen hoeven te doen, en vanaf deze plaats wil ik iedereen die een steentje heeft bijgedragen graag bedanken.

Een aantal van hen wil ik persoonlijk in het zonnetje zetten:

Allereerst mijn eerste promotor: Prof. Dr. M.J.A.P Daemen. Beste Mat, op de lijst van personen die ik wil bedanken krijg jij de ereplaats! Je begeleiding was en is altijd enerverend, en ik heb erg veel van je geleerd. Niet alleen experimenten bedenken en uitvoeren, maar ook presentaties houden, artikelen schrijven en publiceren, inzicht krijgen in die politiek van de wetenschappelijke wereld, projecten schrijven etc. Ook congressen en werkbezoeken met jou als begelei(ij)der waren onvergetelijk. Om maar een paar steekwoorden te noemen: verdwalen met RobertJan in Amsterdam op zoek naar een Italiaans restaurant. Mijn eerste Amerika-reis: nog geen trolley, Amerikaans ontbijten in Boston, muizen offeren bij Biogen, tunastick, vliegen met een kapotte motor, 9 uur vertraging, niet slapen in vliegtuigen, wel overdag. En, als ervaren congresbezoekster; me uitlachen als ik door Steve Schwartz binnen 2 minuten klem gepraat word; je een adrenaline rush bezorgen door (bijna!) te laat te komen voor m'n praatje op de AHA... Kortom, reizen om nooit te vergeten.

Niet alleen voor je hulp bij mijn ontwikkeling tot onderzoeker wil ik je bedanken, ook mijn ontwikkeling tot (bijna?) volwassen persoon. Als klein studentje binnengekomen, heb je er veel moeite en energie ingestoken om me te vormen tot de onderzoekster en persoon die ik nu ben. Dit ging niet altijd even gemakkelijk. Toch is het altijd weer goed gekomen, was je er altijd als ik je echt nodig had, en had ik echt niemand anders als begeleider gewild!

$\mathrm{Mijn}$ student-AlO periode is nu voorbij, en de volgende periode breekt aani postdoc. I $k$ blif nog een aantal jaren bij je, en ik hoop dat je me in deze nieuwe carrièrefase net zo goed, en met net zoveel energie zult begeleiden als in de afgelopen periode.

Prof. Dr. H.J.J. Wellens. Ik wil U zeer danken voor de mogelikheden die $U$ mij heeft gegeven. U was altijd duidelijk op de achtergrond aanwezig, en ik dank U voor het lezen van en het discussiëren over alle artikelen, en natuurlijk voor uw kritische commentaar op dit proefschrift.

Dr. E.D. de Muinck. Beste Ebo, als co-promotor verdien je eveneens een eervolle vermelding in dit dankwoord. Dit proetschrift was er nooit geweest als er geen 100 ApoE*3Leiden muizen bij de CPV zaten! Na verscheidene denudatie-pogingen 
werd het onderzoek een geheel andere kant opgestuurd en zo is het muizenonderzoek naar primaire atherosclerose begonnen. Vooral in hel begin heb je me zeer intensief, en met veel enthousiasme begeleid. Later, toen de tijd er rijp voor was, liet je me wat meer mijn eigen gang gaan, maar bleef je duidelik aanwezig. Voor de link met de kliniek was je onmisbaar, hoewel je poging een psychiater te overtuigen dat experimenten doen voor een Nature Medicine paper belangrijker is dan het co-schap psychiatrie, niet helemaal de gewenste uitwerking hadl Over een aantal maanden ga je zelf de pipetien ter hand nemen op het lab van M. Simons. Ik wens je hierbij veel plezier, en ik ben ervan overtuigd dat je het Maastrichtse 'gene therapy' en angiogenese onderzoek als je terugbent een nieuwe impuls zal geven.

Prof. Dr. P. Carmeliet. Beste Peter, 2 jaar geleden heb ik een aantal maanden op je lab mogen doorbrengen, en ik heb het in die periode echt naar mijn zin gehad. De Leuvense snelheid en effectiviteit van werken, en niveau van discussiëren wekt nog steeds mijn bewondering. Zo zilin de 'Leuvense" termen "labcrash', frigo, oven, aliquoteren, subit, en amay deel geworden van mijn vocabulaire. We werken en discussièren nog steeds samen, en ik hoop dat we deze samenwerking nog lang voortzetten.

I would like to thank the Victor Kotellansky and Linda Burkly from Biogen for the kind provision of the anti-CD4OL antibody. We are still working together on diverse projects, and I hope we can continue our fruitful cooperation.

I would also like to thank Leonid Gorelik and Richard Flavell for the generation and breeding of the CD4OL-/-/ApoE-/-mice. The visit to your lab was unforgettable.

Beste Suzanne, (paranimf), 6 jaar geleden zijn we bij elkaar in huis komen wonen. Het klikte meteen, en na 6 jaar zijn we nog steeds dikke vriendinnen, en hebben we veel samen meegemaakt. Om maar wat te noemen: lekker koken, winkelen, tissues die spontaan in brand vliegen, om 4.00 opstaan om te studeren voor de VAT, in korte broek + rugzak verdwalen in het meest conservatieve moslimdeel van Istanboul... Kortom, dolle pret. Ik vind het geweldig dat je mijn paranimf bent, en ik wens jou en Gert-Jan veel geluk in de toekomst!

Josine, als een van mijn beste vriendinnen hoor je zeker in dit dankwoord thuis. Vanaf de eerste dag van de opleiding geneeskunde zijn we met elkaar opgetrokken. Eerst samen treinen, vervolgens allebei op kamers. Veel samen eten, samen DOTten, diepzinnige gesprekken, samen armen en benen ontleden op de snijzaal, en op hetzelfde lab onderzoek doen. Nu zit je al een aantal jaren met Vincent in Nieuw Zeeland, en zle ik je elgenlijk veel te weinig. Jammer genoeg ben je er op de dag van min promotie niet bij, maar ik hoop dat je voor me duimt! Volgend jaar kom je weer terug om hier te promoveren en co-schappen te lopen. Dan moeten we alle schade maar inhalen!

Sylvia, mijn tweede paranimf. Beste Sylvia, als kamergenootje ben je altijd een stabiele factor geweest in dit onderzoek. Niet alleen heb je altijd een luisterend oor, en ben je een prima discussiepartner, ook ben je altijd degene die in elke situatie 176 
haar kaimte weet te bewaren, en die overdraagt op je omgeving. Babysitten bij Gebbe en Alijt, en ook de etentjes bij je thuis waren altijd erg gezellig. Ik hoop dat je nog een aantal jaren mijn kamergenootje blift en, als je met Jons naar de bioscoop wilt, kom ik met alle plezier oppassen!

Ook de rest van mijn kamergenoten, AlO's, post-docs en analisten wil ik bedanken voor de leuke tijd. Esther en Cherida, als kamergenooljes hebben we veel gekletst, gelachen, maar ook frustraties uitgewisseld. Esther, als cardio-postdoc tussen alle vatenmensen weet je je goed staande te houden. Als mede-puinhoop maakster ben je een prima buurvrouw. Cherida en Birgit, onze Rocky mountain reis zal ik niet snel vergeten. Hiken, aangevallen worden door chipmunks, echte mountainlions en wiebel-enkels, het kan allemaal! Kitty, bedankt voor al je wijze raadgevingen, je betrokkenheid bij mijn onderzoek, en natuurlijk voor de fiets! Meindert, als mede student-AlO, altijd 'enthousiaste' mede-coassistent hebben we ons door de politiek van kliniek en onderzoek een weg weten te banen. Amice, you're next, en ik kijk uit naar onze samenwerking als cardio-pulmonaalchirurg en cardiovasculair patholoog! Ann en je opvolgster Ann-Pascalle, jullie moeten de Belgische eer hooghouden. Ference, succes met je infarcten, CD4OL is echt een geweldig molecuul! Jack, bedankt voor al je hulp (computer, Q-met, project en nog veel meer). Robert-Jan, na Rabinovitch weer terug in Nederland. Bedankt voor je hulp bij het kijken van 'moeoecezenkoepes', en we moeten snel weer samen in de VS winkelen (ik heb nieuwe schoenen nodig). Ton, bedankt voor alle historische athero-informatie.

Ook de analisten Anique, Monique, Wendy, Petra, Loes en Mandy. Heel veel dank voor het aanleren van de geheimen van het lab, en hartstikke bedankt voor het snijden en kleuren van coupes, en al het andere werk dat jullie voor me hebben verzet. Cor, bedankt voor het helpen bij computerproblemen en het regelen van alle financiële en lab-technische zaken.

Ook de mensen van het secretariaat, en men name Carla en Audrey, wil ik bedanken voor al hun 'regeldingetjes'. Mensen van de diagnostiek: bedankt woor jullie hulp.

Verder wil ik ook de mensen van de farmacologie bedanken voor hun medewerking. Prof. Dr. J.F.M. Smits, beste Jos, vooral bij het Mumi-project hebben we veel samengewerkt. Ik heb veel van je geleerd. Bedankt voor je positieve woorden in de examenconmissie, en ik hoop nog dit jaar mijn artsenbul van jou te onlvangen. Jacques, Peter en Nicole, hartstikke bedankt voor het zetten van alle infarcten en alle CO metingen. Jammer genoeg staat jullie werk niet in dit proefschrift, aangezien ik toch voor de vaten gekozen heb. Wendy, onze etentjes waren erg gezelig en diepgaand, succes met je zanglessen en kom je gauw een keertje eten? Marielle. als ex-Leuvense buurvrouw wens ik je veel succes met je promotie. Matthijs, je bent een prima discussiepartner, veel succes met al je nieuwe AlO's en het opvoeden van je beide dochters. Ewald, annexine, apoptose en harten. Samen met Leo een succesvolle combinatie, veel succes.

Vrienden zijn erg belangrijk, en hoewel ik jullie niel allemaal bij naam kan noemen, wil ik jullie allemaal bedanken. Ellen, de weg naar Parijs duurt lang, en de opbouw van de stad Brussel is ook niet helemaal duidelijk...... Ik wens je veel succes met je promotie en, hopelijk, als toekomstig chirurg! Xander, als eerste onderzoekspartner 
hebben we de kneepjes van het vak onder de knie gekregen. Ons eerste experiment duurde 20 uur. mede omdat de vaten waarin een arteriële catheter aangebracht kan worden tairijk zijn! Na 1 jaar zijn we beiden onze eigen weg gegaan, beide succesvol. Succes met je promotie en je CV! Jeroen, als mede student-AlO komt ook jouw promotie in zicht, veel succes hiermee, en natuurlijk met je baan als longarts in Rotterdam. Ferdi, angiogenese-onderzoek en pappa: beide taken zijn je op het lijf geschreven! Anke, als bedrijsskundige zal het je vaak niet helemaal duidelijk zijn wal ik allemaal doe met mijn muizen. Ik hoop dat dit proefschrift verhelderend werkt. Na mijn promotie moeten we maar snel op wintersport.

Ik wil ook de mensen van lab microcirculatie bedanken, het lab waar ik de eerste stappen op onderzoeksgebied gezet heb. Harry, Dick, Mirjam, Erik, Sabrina, Peter en Marc, bedankt.

Alle mensen van het CPV, bedankt voor het verzorgen en fokken van mijn muisjes. Mensen van de AV-dienst, bedankt voor de mooie plaatjes. Bureau onderwijs: zonder jullie was deze student-AIO combinatie niet gelukt, bedankt.

Paps en mams, bedankt voor alle kansen en steun die jullie me in dit leven hebben gegeven. Ik hoop dat dit proefschrift het iets duidelijker maakt wat ik met al die muizen doe! Ook voor de rest van mijn familie: bedankt voor alle steun.

Lieve Tim, twee AlO-banen, twee proefschriften, twee work-o-holics, en toch tijd overhouden voor elkaar! Wat ons betreft een perfecte combinatie! Bedankt voor al je steun en begrip in deze drukke tijden. Nu mag jij。 en daarna: US here we come!

Esther 
Curriculum vitae

Esther Lutgens

4 November 1975

\section{Education}

$1988-1994$

1994-1995

1995-1998

1998- March 2001

Research

1995-1996

1996-1997

1998-now

Visits/Research other labs

1998

1998

1999
Born in Heerlen

Catholic Gymnasium Roiduc, Kerkiade, the Netherlands, Cum Laude

Propaedeuse Medicine, University of Maastricht, the Netherlands

Doctoral phase, Medicine, University of Maastricht, the Netherlands, Cum Laude

Internships, Medicine, University of Maastricht, the Netherlands

Student-worker, dept. of General Surgery, University Hospital Maastricht, the Netherlands

Student-worker, dept. of Cardiology (Prot. dr. H.J.J. Wellens and dr. E.D. de Muinck; W. Pon Foundation), University of Maastricht, the Netherlands

MD-PhD-student (Prof. dr. M.J.A.P. Daemen, Prof. dr. H.J.J. Wellens and dr. E.D. de Muinck; W. Pon Foundation), depts. of Pathology and Cardiology. University of Maastricht, Cardiovascular Research Institute Maastricht (CARIM), the Netherlands

Visit Biogen Inc. Cambridge, MA, USA.

Research in the Howard Hughes Institute of Immunobiology, (dr. RA. Flavell), Yale Medical School, New Haven, CT, USA.

Research in the Center for Transgene Technology and Gene Therapy, KU Leuven, lab of Prof. dr. P. Carmeliet and Prof. dr. D. Collen. 


\section{Awards}

1. Young Investigator Award, $6^{\text {if }}$ Joint Meeting of the Belgian and Dutch Working Groups on Invasive Cardiology. January 8-9 1999, Maastricht, the Netherlands.

2. Dr. E. Dekker grant, the Netherlands Heart Foundation, March-July 1999. Research in the Center for Transgene Technology and Gene Therapy. KU Leuven, Prot. dr. P. Carmeliet and Prof. dr. D. Collen.

3. Young Investigator Award International Society for Heart Research, XXth European Section Meeting. June 21 1999, Maastricht, the Netherlands.

4. Prize for Best Hot Topic Presentation, $4^{\text {th }}$ annual meeting of the European Council for Blood Pressure and Cardiovascular Research (ECCR). October 15 171999 . Noordwikerhout, the Netherlands.

5. New Investigator Travel Award, First Congres on Arteriosclerosis, Thrombosis and Vascular Biology. May 20-22 2000, Denver, Co, USA.

6. EVBA Fellowship, Xith international Vascular Biology Meeting. September 5-9 2000, Geneva, Switzerland.

7. Vasculaire Biology prijs 1999/2000, Parke Davis. October 28 2000. Amsterdam, the Netherlands.

\section{Publications}

1. Lutgens E Cleutjens KBJM, Heeneman S, Koteliansky VE, Burkly L, Daemen MJAP. Both early and delayed anti-CD40L antibody treatment induces a stable plaque phenotype. Proc Nat Acad Sci U S A, 2000, 97: 7464-7469.

2. Kliffen M. Lutgens E, Daemen MJ, de Muinck ED, Mooy CM, de Jong PT. The ApoE*3Leiden mouse as an animal model for basal laminar deposits. Br J Ophtalm 2000, 84: 1415-1419.

3. Lutgens E, Gorelik L, Daemen MJAP, de Muinck ED, Grewal IS, Koteliansky VE, Flavelf RA. Requirement for CD154 in the progression of atherosclerosis. Nat Med 1999, 5: 1313-1316.

4. Lutgens $E_{\text {n }}$ Daemen M. Kockx M. Doevendans P. Hofker M. Havekes L. Wellens $H$, de Muinck ED. Atherosclerosis in APOE 3 Leiden transgenic mice: from proliferative to atheromatous stage. Circulation 1999, 99: 276-283.

5. Lutgens E, de Muinck ED, Kitslaar PJ, Tordoir JH, Wellens. HJ, Daemen MJ. Biphasic palterm of cell tumover characterizes the progression from latty streaks to ruptured human atherosclerotic plaques. Cardiovasc Res 1999, 41: 473-479.

6. Carmeliet P, Lampugnani MG, Moons L, Brevario F, Compernolle V, Bono F. Balconi G. Spagnuolo R. Oosthuyse B, Dewerchin M, Zanetti A, Angellilo A, Mattot V, Nuyens D, Lutgens E, Clotman F, de Ruiter MC, Gittenberger-de Groot, Poelman R, Lupu F, Herbert JM, Collen D, Dejana E. Targeted deficiency or cytosolic truncation of the VE-cadherin gene in mice impairs VEGF-mediated endothelial survival and angiogenesis. Coll 1999, 98: 147-157.

7. Lutgens E, Daemen M, de Muinck Es Debets J, Leenders P. Smits J. Chronic myocardial infarction in the mouse: cardiac structural and functional changes. Cardiovasc. Res. 1999, 41: 586-593. 
Submitted

1. Heeneman S, Lutgens E, Slangen R, Verluyten M, Burkly LC, Koteliansky VE, Daemen MUAP. Inventory of downstream signaling events during anti-CD4OL antibody treatment in ApoE-/- mice.

2. Dhore CR, Cleutjens JPM, Lutgens E, Cleutjens KB.JM, Geusens PPMM, Kitslaar PJEHM, Tordoir JHM, Spronk HMH, Vermeer C, Daemen MJAP. Differential expression of bone matrix regulatory proteins in human atherosclerotic lesions.

3. Lutgens E, de Muinck ED. Heeneman S, Daemen MUAP. Both compensatory enlargement and stenosis develop in ApoE-/- and ApoE*3Leiden transgenic mice.

4. Lutgens $E$, Garcia de Frutos $P$, Apericio $C$, Moons $L$, Janssen $A$, Collen D, Daemen M. Carmeliet P. Gas6-1/ApoE-\% mice develop a collagen-rich, differently organized plaque phenotype, prone to intra-plaque hemorrhage.

5. Blankesteijn WM, Creemers E, Lutgens E, Cleutjens JPM, Daemen MJAP, Smits. JFM. Dynamics of cardiac wound healing following myocardial infarction: observations in genetically altered mice. 